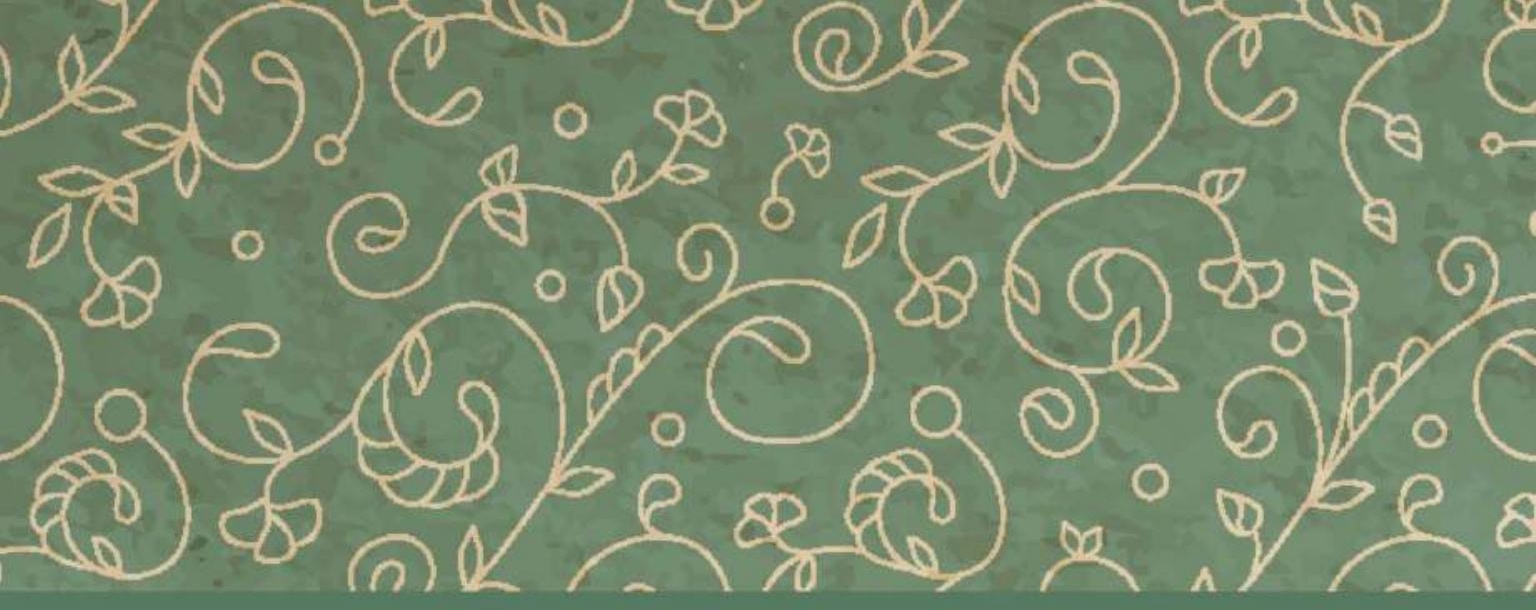

Studies in European Sociology

\title{
EU SOCIAL INCLUSION \\ POLICIES IN POST-SOCIALIST COUNTRIES
}

\section{TOP-DOWN AND BOTTOM-UP PERSPECTIVES ON IMPLEMENTATION}

Edited by

Ingrid Fylling, Elena-Loreni Baciu and Janne Paulsen Breimo

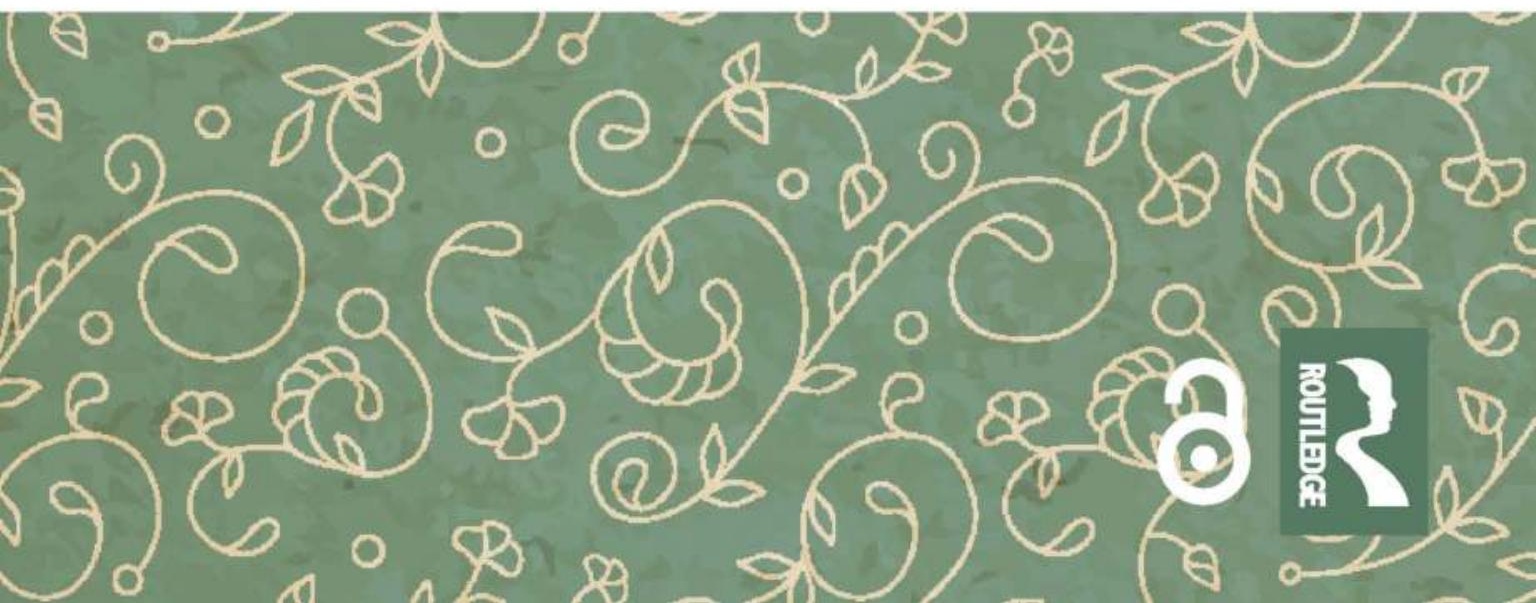




\section{EU Social Inclusion Policies in Post-Socialist Countries}

The fact that post-socialist European Union (EU) countries are struggling with implementation of the EU's social inclusion policy is well known. But why is that so? Are the problems solely connected with how inclusion policies are enforced, or could it just as likely be the way policies are designed that creates challenges? This book explores experiences with inclusion policy implementation in seven different post-socialist EU countries. It focuses particularly on two groups of people in constant danger of social exclusion: people with Roma background and people with disabilities.

So far, researchers have studied these issues primarily through policy analysis, and thus not provided knowledge on what actually happens in local contexts where welfare services are produced. This book sheds light on implementation processes at different levels, both at the policy level and in local welfare production. The picture painted here is one of complex and conflicting considerations in inclusion policy implementation, between historical and cultural heritage from the communist period, and EU inclusion policy based on Western European political principles.

This book will appeal to undergraduate and post-graduate students, as well as postdoctoral students in social science, disability studies, educational science, and others. The book will also be useful for researchers and others interested in the development of inclusion policies and EU integration issues.

Ingrid Fylling holds a position as associate professor in Sociology at Nord University, Norway. Her main research interest is in disability studies and studies of local welfare services. She is also a board member of the Nordic Network for Disability Research. Latest publication (co-authored): Fylling, I. and Melbøe, L. (2019). Culturalisation, homogenisation, assimilation? Intersectional perspectives on the life experiences of Sami people with disabilities. Published in Scandinavian Journal of Disability Research, 2019 http://doi.org/10.16993/sjdr.575.

Elena-Loreni Baciu is an Associate Professor at the Social Work Department from the West University of Timisoara, Romania and a co-founder of the Research-Action Centre on Discrimination and Social Inclusion at the same University. (Co)-authored publications: Between equality and discrimination: disabled persons in Romania (2017); Exploring the social relations of Roma employability (2016); Romanian Roma: an institutional ethnography of labour market exclusion (2016).

Janne Paulsen Breimo is a professor in social work at the Faculty of Social Sciences, Nord University, Norway. Her research interests include social policy and social welfare. She is the chair of the European Sociological Association's Research Network on the Sociology of Social Policy and Social Welfare (RN26). Co-authored publications: Romanian Roma: an institutional ethnography of labour market exclusion (2016); Networking enforced - comparing social services' collaborative rationales across different welfare regimes (2016); Planning individually? Spotting international welfare trends in the field of rehabilitation in Norway (2016). 


\section{Studies in European Sociology}

Routledge/European Sociological Association Studies in European Societies

Series editors: Thomas P. Boje, Max Haller, Martin Kohli and Alison Woodward

17 The Social Meaning of Children and Fertility Change in Europe Edited by Anne Lise Ellingsæter, An-Magritt Jensen and Merete Lie

I 8 Religion, Identity and Politics

Germany and Turkey in Interaction

Edited by Haldun Gülalp and Günter Seufert

19 Post-identity?

Culture and European Integration

Edited by Richard McMahon

20 Artistic Practices

Social Interactions and Cultural Dynamics

Edited by Tasos Zembylas

2 I Collective Memories in War

Edited by Elena Rozhdestvenskaya, Victoria Semenova, Irina Tartakovskaya and Krzysztof Kosela

\section{Green European}

Environmental Behaviour and Attitudes in Europe in a Historical and

Cross-Cultural Comparative Perspective

Edited by Audrone Telesiene and Matthias Gross

23 Wage Distribution Fairness in Post-Socialist Countries

Situation and Socialization

Zsófia Ignácz

24 EU Social Inclusion Policies in Post-Socialist Countries Top-Down and Bottom-Up Perspectives on Implementation Edited by Ingrid Fylling, Elena-Loreni Baciu and Janne Breimo

www.routledge.com/Studies-in-European-Sociology/book-series/SE0204 


\section{EU Social Inclusion \\ Policies in Post-Socialist Countries}

Top-Down and Bottom-Up Perspectives on Implementation

Edited by

Ingrid Fylling,

Elena-Loreni Baciu and

Janne Paulsen Breimo

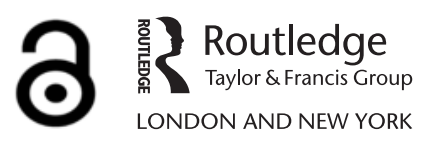


First published 2020

by Routledge

2 Park Square, Milton Park, Abingdon, Oxon OXI4 4RN

and by Routledge

52 Vanderbilt Avenue, New York, NY 10017

Routledge is an imprint of the Taylor \& Francis Group, an informa business

(C) 2020 selection and editorial matter, Ingrid Fylling, Elena-Loreni

Baciu and Janne Paulsen Breimo; individual chapters, the

contributors

The right of Ingrid Fylling, Elena-Loreni Baciu and Janne Paulsen

Breimo to be identified as the authors of the editorial matter, and of the authors for their individual chapters, has been asserted in accordance with sections 77 and 78 of the Copyright, Designs and Patents Act 1988.

With the exception of Chapter 2, no part of this book may be reprinted or reproduced or utilised in any form or by any electronic, mechanical, or other means, now known or hereafter invented, including photocopying and recording, or in any information storage or retrieval system, without permission in writing from the publishers.

Chapter 2 of this book is available for free in PDF format as Open Access from the individual product page at www.routledge. com. It has been made available under a Creative Commons Attribution-Non Commercial-No Derivatives 4.0 license

Trademark notice: Product or corporate names may be trademarks or registered trademarks, and are used only for identification and explanation without intent to infringe.

British Library Cataloguing-in-Publication Data

A catalogue record for this book is available from the British Library

Library of Congress Cataloging-in-Publication Data

A catalog record for this book has been requested

ISBN: 978-I-I 38-35280-3 (hbk)

ISBN: 978-0-429-43454-9 (ebk)

Typeset in Times New Roman

by Wearset Ltd, Boldon, Tyne and Wear 


\section{Contents}

Notes on contributors

vii

Acknowledgements

1 Implementing social inclusion policies in post-socialist EU countries: stumbling blocks and stepping stones

ELENA-LORENI BACIU, INGRID FYLLING, AND JANNE

PAULSEN BREIMO

2 Independent living in Central and Eastern Europe? The challenges of post-socialist deinstitutionalization

TEODOR MLADENOV AND GABOR PETRI

3 The limits of projects: translating the social inclusion of Roma in Serbia

TIJANA MORAČA AND PAUL STUBBS

4 Ethnicizing poverty, implementation of structural funds in Slovakia

JOANNA KOSTKA

5 Policies for whom? Roma as ethnic and/or national minorities: the case of Hungary and the European Union

ANDRAS L. PAP

6 How can we understand the poor implementation of disability inclusion policy in Romania? 
7 EU social inclusion policy implementation in Poland 1989-2018

RYSZARD SZARFENBERG

8 Social inclusion and political participation of persons with disabilities in Slovakia

ALEXANDRA STRÁŽNICKÁ

9 Social economy entities as a practical instrument to enhance social inclusion in Poland

URSZULA BRONISZ, ANDRZEJ JAKUBOWSKI,

MAGDALENA MISZCZUK, AND ANDRZEJ MISZCZUK

10 The promotion of social inclusion in the Slovak education system through 'Teach for Slovakia' programme

GÁBOR SZÜDI AND JAROSLAVA SZÜDI

11 The integrated approach in practice: a framework for Roma work inclusion. Case studies from Romania

THEOFILD-ANDREI LAZĂR AND MELINDA DINCĂ

12 Inclusion policies between EU framework and post-socialist heritage

INGRID FYLLING, ELENA-LORENI BACIU, AND

JANNE PAULSEN BREIMO

Index 


\section{Contributors}

Teodor Mladenov is currently Marie Curie Individual Fellow at the European Network on Independent Living, and formerly was Leverhulme Early Career Fellow at the Centre for Public Policy Research, King's College London. He is author of Critical Theory and Disability: A Phenomenological Approach (2015, Bloomsbury) and Disability and Postsocialism (2018, Routledge). In the period 2000-2009, Teodor was actively involved in disabled people's advocacy for independent living and social justice in Bulgaria.

Gabor Petri is currently $\mathrm{PhD}$ Candidate at the University of Kent, Tizard Centre. He has nearly 20 years of experience in disability advocacy in Hungary and in the EU. His research interests include self-advocacy of autistic people and people with a learning disability, the disabled people's movement, disability human rights, mental health policies and community living. Gabor is also member of the Board of Directors of the European Disability Forum and the Mental Health and Human Rights Committee of the Brusselsbased NGO Mental Health Europe.

Tijana Morača earned her $\mathrm{PhD}$ at Sapienza University in Rome. In her thesis she explored how higher education and Roma social inclusion policies are translated in the scope of their implementation in present-day Serbia. She is interested in issues of policy translation, civil society, and post-socialism. She has been engaged in civil society development, international cooperation, EU integration and welfare reforms for the past 15 years in the role of NGO worker and consultant.

Paul Stubbs is a UK-born sociologist who works as a Senior Research Fellow in the Institute of Economics, Zagreb, Croatia. His main research interests focus on: social protection and social inclusion; policy translation; moral political economies; and the history of socialist Yugoslavia and the Non-Aligned Movement. His most recent books include Social Policy, Poverty, and Inequality in Central and Eastern Europe and the Former Soviet Union (edited with An, Chubarova, and Deacon, Ibidem 2019) and Social Inequalities and Discontent in Socialist Yugoslavia (edited with Archer and Duda, Routledge 2016). 
Joanna Kostka is Lecturer in Social Work at Lancaster University, UK. Currently she teaches MA1 Module Social Divisions and Social Diversity (SWK.421) and BA1 Contemporary Social Problems (SWK.116). She has collaborated on numerous international research projects (including Horizon 2020, ERASMUS for Young Entrepreneurs) and has worked with different research centres, in policy consultancy, and with advocacy institutions. Her research interests include EU public policy (European integration, equality policy, cohesion policy), minority issues (with specific focus on Roma inclusion), theories of migration, participatory action research, community development, social movements, and postcolonial studies.

Andras L. Pap is Research Chair and Head of Department for the Study of Constitutionalism and the Rule of Law at the Hungarian Academy of Sciences Institute Centre for Social Sciences Institute for Legal Studies, Professor of Law at the Law Enforcement Faculty of the National University of Public Service, Budapest, and Adjunct (Recurrent Visiting) Professor in the Nationalism Studies Program at the Central European University in BudapestVienna. Currently, he is on leave from Eötvös University (ELTE) Institute of Business Economics, in Hungary. Throughout 2016-2019 he was SASPROMarie Skłodowska-Curie Fellow at the Institute of Sociology of the Slovak Academy of Sciences in Bratislava. In 2018 he founded the International Association of Constitutional Law (IACL) Research Group on identity, race, and ethnicity in constitutional law.

Johans Tveit Sandvin is Professor of Sociology at Nord University, Norway and Head of the Doctoral School in Sociology. He has published widely in the fields of Social Policy and Disability Studies. He is former chair of the Norwegian State Council on Disability, member of the Norwegian AntiDiscrimination Tribunal, and the national representative of Academic Network on European Disability Experts (ANED).

Teodor Mircea Alexiu is currently an Associate Professor at the Department of Social Work within the West University in Timişoara (Romania). He has been a member of the Romanian Government Commission against Poverty and Social Exclusion, an expert in the TEMIR programme (Transformation of Educational Management in Romania), an expert in the Academic Consultant Group of the Direction for Social Reintegration (Ministry of Justice), and a collaborator for the Ministry of Education and Research in Romania. Among his areas of expertise are counted: social policy, social work interventions with disadvantaged categories, and social research methods and methodologies.

Ryszard Szarfenberg is University Professor in Political Science at the Institute of Social Policy, University of Warsaw, Poland. He completed his graduate programme at that university and prepared a thesis on the rationalization of social policy during the period of transformation in Poland. He was awarded 
his habilitation degree based on a book about argumentation over the welfare state. He has published his work in major Polish academic journals focused on social policy (Problemy Polityki Społecznej, Polityka Społeczna). His main research interest is action research, which combines evidence about poverty and social assistance with social policy advocacy in the context of Europeanization. He is a member of the EU Inclusion Strategy Group of the European Anti-Poverty Network and Chairperson of EAPN Poland network. He has had published, numerous academic articles about social policy and the welfare state, poverty and social exclusion, social assistance, non-contributory cash benefits, and basic income.

Alexandra Strážnická is a member of the Faculty of Social and Economic Sciences, at the Comenius University in Bratislava (Slovak Republic). She is also responsible for International Relations and Legislation within the Research Center for Human Rights at the same university. Her research interests include Law and Legal Studies, Legal Analysis, and Human Rights and Democracy.

Urszula Bronisz is Doctor of Human Science in the field of Political Science, and is Assistant Professor at the Faculty of Earth Sciences and Spatial Management Maria Curie-Skłodowska University in Lublin; she is also specialist at the Lubelskie Centre for Regional Studies (Statistical Office based in Lublin). She graduated from the Faculty of Political Science and the Faculty of Economics of Maria Curie-Skłodowska University. Urszula is author and co-author of numerous books, journal articles, and chapters in books. Her main areas of interest are local and regional development and EU regional policy.

Andrzej Jakubowski is Doctor of Social Science in the field of Political Science, and is Assistant Professor at the Faculty of Earth Sciences and Spatial Management, Maria Curie-Skłodowska University in Lublin; he is also senior specialist at the Lubelskie Centre for Regional Studies (Statistical Office based in Lublin). He graduated from the Faculty of Political Science of Maria Curie-Skłodowska University. Andrzej is the author and co-author of more than 50 books, journal articles, and chapters in books. His main areas of interest are regional development and cross-border and peripheral areas. He is a member of the Regional Studies Association.

Magdalena Miszczuk has a $\mathrm{PhD}$ in economics and is Assistant Professor at Lublin University of Technology (Faculty of Management, Department of Finance and Accounting). She graduated in 1983 from Maria CurieSkłodowska University in Lublin, having studied at the Faculty of Economics. In 1997, Magdalena received her Doctorate in Economics (Finance) from Maria Curie-Skłodowska University in Lublin. She has conducted research into public finance, local and regional development, EU regional policy, functioning of local self-governments in Poland and the European 
Union, and NGOs. She has had published (as author and editor), four books and over 80 journal articles and chapters in books.

Andrzej Miszczuk is Professor at Maria Curie-Skłodowska University, Faculty of Economics, and is Head of the Department of Economic, Social and Regional Policy. He graduated from Maria Curie-Skłodowska University in Lublin (Faculty of Economics) in 1984. Andrzej received his doctorate in 1991 and his habilitation doctorate in 2004 in Social-economic Geography at the Institute of Geography and Spatial Organization of the Polish Academy of Science. He has conducted research on local and regional development, EU regional policy, functioning of local self-governments in Poland and European Union, trans-border cooperation, and NGOs. He has also published (as author and editor) 16 books and over 180 journal articles and chapters in books. Andrzej is a member of the Committee for Space Economy and Regional Planning of the Polish Academy of Science; Expert of the National Science Centre and the Ministry for Regional Development; and member of the editorial board of the quarterly scientific journal Regional Barometer.

Gábor Szüdi gained his $\mathrm{PhD}$ in Economic Policy at the University of Economics in Bratislava, Slovak Republic. His thesis focused on the potential links between the shift to knowledge economies and growing income disparities in the most advanced country groups. His research interests include social innovation, social inclusion, and inclusive innovative solutions in public services; related to these topics he has been dealing with international research projects in the frameworks of COST, South East Europe, DTP Interreg, Leonardo LLL, FP7, and H2020 programmes. At the moment Gábor works at the Centre for Social Innovation in Vienna, Austria and at the Central European Labour Studies Institute in Bratislava, Slovakia as a Research Associate.

Jaroslava Szüdi is employed at the Ministry of Education, Science, Research and Sport of the Slovak Republic at the Department of Strategies and European Affairs. Previously she worked as an Assistant Professor at the University of Economics in Bratislava where she gave lectures on subjects concerning economic and social development. In her research she deals in particular with the topics of social innovation and quality of life of marginalized social groups. Within her ministry-related work she is mostly engaged with macroregional strategies and their role in the development of the knowledge society. Research \& development and educational policies, eLearning and lifelong learning, coaching, leadership, and personal development are included in her areas of interest.

Theofild-Andrei Lazăr gained his $\mathrm{PhD}$ in Sociology in 2010 and Habilitation in Sociology in 2018, and is currently member of the Doctoral School in Sociology at the West University in Timișoara, Romania. He is also an Associate Professor at the Social Work Department within the Faculty of Sociology and 
Psychology at the same university. His research interests focus on social work, social services, community development, social integration of vulnerable groups, employment strategies, and penitentiary studies. He has extensive experience in the implementation of development projects addressing increasing social inclusion of vulnerable groups.

Melinda Dincă gained her $\mathrm{PhD}$ in Sociology in 2008 at the University of Bucharest. She has 20 years of academic activity experience as a sociologist and researcher, and has held various academic teaching positions in the field of Social Sciences at the West University of Timişoara, Romania. She has participated as a researcher and consultancy expert for several regional or international research, knowledge transfer, and policy development and assessment projects. 


\section{Acknowledgements}

This project has taken a few years to complete, and includes collaboration between researchers from eight different countries. We have, therefore, many people and institutions to thank.

The idea for a book project on the implementation of EU inclusion policies in post-socialist EU countries was born during a Romanian-Norwegian three-year research project on experiences of labour market inclusion for people with disabilities and people with Roma backgrounds in Romania. We therefore feel the need to thank the EEA grants for financing the research project 'E-QUAL Qualitative research on the professional integration of vulnerable groups' (contract number 13SEE/ 2014). We also want to thank West University in Timisoara, Romania and Nord University in Bodø, Norway, for institutional support.

We are so proud to be part of presenting our chapter authors' interesting research. To Teodor M, Gabor P, Urszula, Andrzej J, Magdalena, Andrzej M, Andras, Teodor A, Alexandra, Melinda, Johans, Theofild, Paul, Joanna, Tijana, Gabor, Jaroslava, and Ryszard: Without you all, this book would never have seen the light of day. We are really grateful for all your effort, your insights, your ability to act on very short notice, and your extended patience with the three editors. We hope to get the chance to collaborate again!

Thanks to everyone at Routledge who have taken part in assisting us with content quality as well as all the necessary and yet confusing technical details. A special thanks to Emily Briggs, who has followed the book process almost from the start and to Lakshita Joshi for providing us with all the help needed in order to complete our tasks.

Our colleagues from the Romanian-Norwegian research team deserve special thanks: Teodor Alexiu, Johans T. Sandvin, Melinda Dinca, Theofild Lazar, and Andrea Birneanu. You have been excellent colleagues and friends: supporting and confronting simultaneously, hardworking, and with a lot of good ideas.

Last but not least, a specially warm thank to our families for your patience and support. This book has taken quite a lot of late nights and weekends away from family life. For this we apologize. We are so lucky to have you in our lives. 


\title{
Implementing social inclusion policies in post-socialist EU countries: stumbling blocks and stepping stones
}

\author{
Elena-Loreni Baciu, Ingrid Fylling, and \\ Janne Paulsen Breimo
}

\section{Introduction}

Former communist countries that have joined the European Union (EU) face difficulties in adapting to and implementing EU policies on the inclusion of disadvantaged populations. The EU has addressed this through redistributive regional programmes, extensive inclusion policies, and action plans targeting the most vulnerable populations. Nonetheless, development is slow and the question remains as to how well the social policies developed by the EU, and the mechanisms established to enforce them in various countries, address the actual problems on the ground. Although EU policies often are incorporated into national policies and legislation, they do not seem to have much impact on the ground for the groups in question. Two central questions raised in this book, therefore, are as follows:

1 Is it possible to identify common features across post-socialist EU countries regarding the problems of implementing EU social inclusion policies?

2 And if so, would it be reasonable or even possible to explain those similarities as a consequence of the post-socialist experience?

The transition from totalitarianism to democracy represents a complete paradigm shift for the former socialist countries, and this has required the rethinking and restructuring of the entire conceptual framework that has long governed the social life of their citizens. In most of these countries, the transitions have been neither smooth nor swift. They have involved profound reforms in all aspects of life, often followed by long periods of stagnation or even civil unrest among the population. Moreover, the recent developments in some of the countries bear witness to a concerning disengagement from some EU ideals (i.e. the politicizing of civil society funding in Poland and Hungary, interpreted as a strategy to discourage opposition among civil society against a more and more authoritative regime, and the controversial judicial reforms that seem to weaken the rule of law in Romania), doubled by an increase in the power of populist parties that rely on nationalist discourse in winning their audiences, and this shows how fragile such a trajectory can be. 
In order to understand the challenges faced by the EU in recent times, it is of utmost importance to understand how past experiences influence current trajectories. To ignore the communist past in interpreting these trajectories means simply to dismiss what could be an irreplaceable lens that allows a unique perspective into the way the citizens from the former communist countries and their leaders have assimilated the new and different ways of doing and thinking and have grafted them into the old ways that were acceptable and familiar to them. The adaptation to and assimilation of the democratic European ideology, particularly in relation to vulnerable categories of the population, who were of marginal interest to previous regimes, deserve special attention. The purpose of this editorial project is to capture the various nuances of transition from one doctrine to another, showing the commonalities of such transitions for the countries involved in addition to discussing the various ways in which each country has experienced the transitions and adapted to them.

The EU inclusion policies are ambitious in that they aim at the complete inclusion and participation of all marginalized groups. Nevertheless, a more thorough scrutiny of policy documents leaves the impression that policies are stronger when it comes to the formation of ideals rather than the formulation of concrete and coherent strategies, and the so-called integrative approach can often make specific prioritization difficult. On the other hand, the 'open method of coordination', initiated by the European Employment Strategy (EES) and since applied to social inclusion and other areas, has raised criticism for being a 'soft law' (Trubek and Trubek, 2005) that will not be able to deliver the expected outcomes, in addition to being in need of a timely recalibration (Borrás and Radae1li, 2010). Within the Europe 2020 Strategy, whereby concrete objectives are defined, the targets set for fighting poverty and social exclusion are to be reached along with objectives that hold far more political weight. For instance, the target set for employment is that at least 75 per cent of the population aged 20-64, is employed. This measure, which has great economic significance and far more substantial political support than have inclusion policies, will probably lead to the prioritization of those who are most easily employed, which could cause marginalized groups to end up even farther back in the queue.

Previous research on this problem has largely focused on policy analysis (Rasell and Jarskaia-Smirnova, 2014; Kuitto, 2016). The top-down perspective is obviously necessary when trying to understand extensive processes of change or resistance to change in the area of social inclusion of disadvantaged populations, and thus some authors have observed that the 'new' modes of governance and regulation at the EU level, especially the Open Method of Coordination (OMC), have changed the nature of European integration (Treib et al., 2007) by promoting the willingness of the Member States to act in a synchronized manner. This allows for the advancement of a shared vision on the European social project, and at the same time it allows for the greatest possible national autonomy (Borrás and Radaelli, 2010) in enacting it. However, others point out that national governmental actors used them 'to learn from the EU or from peer 
countries only when it coincided with the national political agenda' (de la Porte and Pochet, 2012, p. 343). For example, Orenstein (2008) provides an analysis on how the Central and Eastern European (CEE) countries managed to 'outliberalize' the EU social policy and enabled welfare-state retrenchment and pension privatization during the process of accession. Thus, when analysing the developments in the coordination process between EU and national social policies of the Members States in the area of social inclusion of disadvantaged populations, a particular aspect that requires attention is the way in which the EU policy responds to the interests and profiles of these Member States.

Additionally, as pointed out by Trnka and Trundle (2014), the 'ideologies of social contracts rest upon long-standing notions of relations between self and state, or self and collective ... which foreground forms of dependency, interdependency, and recognition' (ibid., pp. 149-150). These notions are not imposed by governments, but rather they spring from shared beliefs of the people, are woven into cultural representations and social ideologies, and are enacted within interpersonal relations. This is why the shift from communism to capitalism in the EU's former communist countries is not just a matter of institutional reform, but also a matter of ideological transition of their citizens, who have to support this reform over time (Migheli 2016). This brings up the need for a bottom-up perspective in our analysis in order to explain how the process of change in the area of social inclusion of disadvantaged populations interacts with and builds on pre-existing social and cultural representations among the people from former communist countries.

\section{EU social inclusion policies}

Social inclusion is the act of making all groups of people within a society feel valued and important. The concept has gained global attention, and there is a broad measure of agreement on domain content around the world - including employment, finance, leisure, social activity and participation, family and friends, housing and living conditions, and safety (Huxley, 2015). Promoting social inclusion has gained substantial political attention in the EU lately. The Lisbon Strategy ended in 2010 with the new Europe 2020 Strategy with the objectives of 'smart, sustainable and inclusive growth' (European Commission, 2010). The new strategy got off to a slow start in an environment of recovery from the financial crisis (Marlier and Natali, 2010). Measuring social inclusion is difficult because it will always happen at particular times and in particular places (Byrne, 2005). For example, while ownership of two cars would be a proxy for material well-being in some parts of the world, this would make no sense in a city like Hong Kong (Huxley, 2015). Still, many scholars have tried to develop measurement indicators suited for making comparisons between countries. For instance, Rogge and Konttinen (2018) investigated social inclusion performance by EU Member States from 2005 to 2014. They found that although old Member States generally outperformed the new Member States in social 
inclusion, some of the new Member States were not lagging far behind. In particular, Slovakia and the Czech Republic scored above average on social inclusion indicators. The authors conclude that overall there has been a slight increase in progress and cohesion in the EU regarding social inclusion. Still, 1 out of 4 Europeans live in poverty or social exclusion (ibid.). Social exclusion, the counterpart of social inclusion, is defined by Castells (1998, p. 73) as a process 'by which certain individuals and groups are systematically barred from access to positions that would enable them to construct an autonomous livelihood within the social standards framed by institutions and values in a given context'. Castells' definition would in our opinion be useful for this book, pointing out that the space for how social inclusion can be designed is defined by context and appropriate institutions within this context.

Since 2007, the EU 'has made a policy decision in favour of more broadly defined strategies of fostering social inclusion' (Sobotka and Vermeersch, 2012). In other words, strategies are less targeted towards specific groups. Because the causes of social exclusion vary widely among the affected groups, the risk is that policies become limited to superficial, temporary measures, often supported exclusively through EU financing with no real commitment by national governments to create sustainable long-term programmes. Profiroiu and Profiroiu (2006) call this strategy a reactive implementation of a policy, which refers to a policy that is 'advanced due to international pressure rather than being driven by the convictions of local politicians or voluntary decisions of the central government' (ibid., p. 121). The overall social policy in the EU has long moved in the direction of activation policies and more conditional rights. The Lisbon Strategy (2000-2010), aimed at increasing employment through integration of social and economic policies, is one such example, reflecting the perception that employment is primarily a question of motivation and morals despite the fact that barriers to employment have long been the most important political issue for the disability movement (Priestley, 2003; Roulstone and Barnes, 2005; Shah and Priestley, 2011). It is argued that so long as the EU's equalization and antidiscrimination policies are mostly expressed in general terms, rather than targeting specific groups and the various causes for their discrimination and exclusion, such groups are likely to remain in unfavourable positions.

\section{Implementing social policies in post-socialist countries}

Traditionally, political science theorists have focused on the problems of implementing policies on the ground, as illustrated by the seminal work of Pressman and Wildavsky from 1973 titled 'Implementation. How great expectations in Washington are dashed in Oakland' (3rd edn, 1984). This is one of the most influential works on implementation and implementation failure in political science, and the problems of implementation have always been of high relevance and have gained a lot of attention. However, as Ansell et al. (2017) argue, the 
problems are just as likely to be connected to how policies are designed as to how they are enforced. They argue that classic implementation theories often conceal flawed and ill-conceived policy designs (ibid.). This book also takes this perspective and asks whether the problems of implementing EU social policies are merely due to national problems of implementation or whether they are additionally related to features of the policies to be implemented. DeLeon and deLeon (2002) argue that 'policy implementation may be the most devilish of all wicked problems'. As a consequence, this phenomenon has been studied by political scientists (among others) for decades. As mentioned above, studies of implementation have often focused on the problems on the ground or on the local level that make it difficult to implement government programmes. In addition, more often than not policy implementation studies have had a top-down character. There are exceptions from this trend, among others Michael Lipsky's (1980) seminal work on street-level bureaucrats and Hjern and Hull's (1982) study on implementation structures. These researchers argued that implementation needed to be an essential part of policy formulation calculations (deLeon and deLeon, 2002). Since then scholars have attempted to create models aimed at taking into account that different conditions might require different implementation strategies. Matland (1995), for example, claims that there is no single best implementation strategy and that the appropriate strategy is contextual depending on a number of variables.

In general, the new post-communist EU Member States from the expansions in 2004 and 2007 are poorly integrated in comparative welfare research (Romano, 2014; Kuitto, 2016). However, during the last few years we have seen some fruitful contributions to understanding the characteristics of the welfare systems in the CEE new EU Member States. Many of them (e.g. EspingAndersen et al., 2002; Ellison, 2006; Kuitto, 2016) argue that the process of reconfiguring welfare policies and systems in CEE countries has been challenging because it has taken place during a period of changing circumstances for all the European countries, including intensified globalization of the economy and markets, major demographic changes, and austerity in the social security arrangements and provisions. Kuitto (2016) claims that in such transitional settings with a strong need for reconfiguration of policies, 'diffusional effects like policy learning are more likely to have had an impact on policies than in more settled circumstances' (ibid., p. 2). At the same time, there might be certain patterns of more or less recognized resistance towards new and unfamiliar ideas and policies in CEE welfare systems, professions, cultures, and practices formed under very different regimes in the past. Whether this is the case or not is still to be explored because the growing body of research on welfare systems in CEE countries so far has been largely in the form of policy studies. This is why we argue that the study of implementation practices in this volume will represent an expansion of our understanding of welfare practices regarding vulnerable groups in post-socialist EU countries. 


\section{The dynamics of welfare states in European former communist countries}

From the explanatory stances used by most of the scholars that dedicated their efforts to analysing or theorizing about the post-1989 trajectories of the welfare states in European former communist countries, there are two that we find useful for this volume: (1) a path dependency stance (which argues for the persistence of expectations and notions of social justice derived from the state socialism ideology and institutional architecture, well after their dissolution); and (2) a path departure (Offe 2010), or policy diffusion (Fenger 2007) stance (which projects the expectancy of a definitive rupture with state socialism, and a subsequent adherence to 'European' models in organizing the welfare state - the Europeanization of social policies). The first stance is supported by arguments like the strengths of the communist legacies (Pierson, 2004), which were inevitably projected over the postsocialist welfare-state adaptation since the beginning (Polese et al., 2014), or the effects of nostalgia over the 'comprehensive paternalist care' (Offe, 2010), when people confronted with the upheavals of the transition to democratic capitalism (like growing inequalities) discover 'how democracy works' and feel disillusioned because it does not fit with the image they had of it.

The second stance, in turn, is based on the argument of convergent influences coming from two different sources (ibid.), namely the requirements of international financial institutions (like the World Bank) and the 'conditionalities' imposed by the EU on those who desired to adhere to it regarding the alignment to certain standards and expectations that (more or less directly) also reflect the recalibration of the welfare states and the modelling of the post-socialist welfare policies. This transitional paradigm of Europeanization of social policy in postsocialist countries proposes that the welfare arrangements in these states would in time evolve towards one or the other of the already consecrated welfare regimes in the rest of Europe (social democratic, conservative, or neo/liberal) (Fenger, 2007).

However, subsequent attempts at the assessment and classification of the post-socialist welfare regimes showed that they resist being definitely placed in one category of Esping-Andersen's threefold typology (which makes them different from the other European states) as well as being definitely placed in the same group ${ }^{1}$ (making them different among themselves) (Fenger, 2007; Polese et al., 2014). Many researchers are critical towards attempts at finding one "postsocialist welfare model' (Romano, 2014; Kuitto, 2016). Rather, the advice from Romano (2014) when analysing welfare models in post-socialist EU states is to be aware of the large differences but at the same time 'not overlook their similarities'.

Somewhat paradoxically, Offe (2010) explains this differentiation through a commonality - the sudden collapse of the communist regime in all of these countries, at about the same time, and the urgent need for the restructuring of the system, placed the countries in an impossible situation for building their new 
welfare systems 'from the ground' with a revolutionary project or a coherent model in mind. Instead, working in an 'emergency mode', they tried to repurpose or recalibrate what they already had put in place. Hence, the mishmash of distinctiveness and similarity that makes the post-socialist (Eastern European) welfare states a case, although not a group. Their appearance and development did not have the same contexts and conditions as those from the other (Western) European states had.

Arguing for an alternative standpoint in looking at the social policy making and implementation in post-socialist countries, Polese et al. (2014) propose the structure-agency paradigm that focuses the attention from structural factors to domestic and local actors (mainly on the ways in which they contribute to permanently shape and renegotiate the welfare policies). They argue that the path between the conception, definition, and implementation of policies is not guaranteed as such, but rather is paved with obstacles from actors at different levels, among which the local ones are paramount.

\section{Post-socialism}

The application of the state socialism doctrine involved an explicit dichotomy between the 'collective' (public) and the 'individual' (private), with the express prioritization of the former over the latter, and this initially stemmed from the perspective on the means of production but rapidly extended to other areas of social life. It was internalized as a valued ideology, promoted through education, and practised in all social settings for almost half of a century, and the interests of the country, the state, and the ruling party became the altars on which the individual interests (and often - in the bloodiest of the regimes, like that of Ceausescu's - the individuals themselves) were sacrificed, without leaving any room for questioning or alternatives. The conformity with this ideology became a mandatory criterion for individual social mobility, be it upward or downward, and it made 'model citizens' or unmade them into 'enemies of the state'. It pervaded so many areas of the individual's life that it is almost impossible to account for all of its influences. For example, it made the practice of people spying upon each other, and further reporting suspicious deeds to the authorities, not just socially acceptable but morally desirable: the state's enemies are lurking everywhere, so people should stay alert to protect their country. Most often, the one who would 'turn you in' would be the work colleague or neighbour, but sometimes it could also happen that he/she was a family member.

With the fall of the communist regime at the beginning of the 1990s, the ideology of the superiority of the collective over the individual was abruptly suspended and swiftly replaced with another - that of human rights, which, by its very definition, is the exact opposite.

But streaming the values of a society's members from one direction towards another is not something that can be done overnight, or exclusively top-down, from the central level, simply through the acquis communautaire (which is 
necessary, although not sufficient), as shown by a recent poll by the Pew Research Center (2018) that captures the visibly contrasting attitudes of Western and Eastern Europeans on key topics like tolerance of minorities, abortion rights, or the place of Christianity in their national identity, more than a decade after the EU started its expansion towards the East.

Local structures, experiences, and representations must also be taken into account because actors who participate equally in the construction of the social ideals are at the same time the main beneficiaries of these constructions. In any given community, the change imposed or requested from outside is rarely welcomed at the local level if not deemed necessary or desirable by the community members themselves. In the absence of such necessity or desirability rooted in the local, the most probable reaction the change will trigger among the local members will be resistance, be it active (upfront opposition) or passive (like fear or suspicion).

In the academic literature on the transition of European former socialist countries, the idea of post-socialism as an 'unfinished business' emerges from time to time (Roper, 2000; Bailyn et al., 2018), evoking the lingering of the past over their future trajectories. From this perspective, as Pupovac (2010) notes, the 'post' becomes a flawed concept in itself, 'a temporal caricature, ... a floating historical state', suspended between negation of the past (for sure not communist) socialist anymore) and anxious anticipation of an uncertain future (but what? and when?), which until now had as sole documented outcomes the increase of poverty and the rise of inequality in these countries (ibid.).

Partly due to this state of ideational duality (not anymore, but also not yet) when approaching post-socialist trajectories, it is difficult to trace positively the 'real' causes of these two outcomes (poverty and inequality). They could be equally construed as rooted in the past (and, thus, understood as undesired legacies of it) or derived from what is not yet achieved as an 'accomplished' future (and, thus, conceptualized as a perpetual failure to align with the European values).

\section{This volume}

This book focuses on two target groups - persons with disabilities and the Roma ethnic group - both identified as 'bivalent collectivities' in the framework of interpretation provided by Fraser (1998), meaning that both negative politicaleconomic and cultural-valuational dimensions intersect in these two groups, making them the target of socioeconomic and cultural-symbolic injustice. With its estimated population varying between 6 and 16 million, with an average of roughly 11 million, the Roma and Travellers ${ }^{2}$ population represents one of the largest ethnic (although stateless) ${ }^{3}$ minorities in Europe (Council of Europe, 2012). At the same time, based on the results of the latest European Union Minorities and Discrimination Survey (EU-MIDIS - European Union Agency for Fundamental Rights 2017), they are also among the most discriminated 
against, and their 'ethnic origin or immigrant background' remains the most common ground for discrimination in respondents' daily lives - affecting 25 per cent of all respondents during the five years preceding the survey. Roma respondents indicated the second highest level of discrimination (41 per cent) based on ethnic or immigrant background. It is important to note that currently in the EU there is no precise definition of what a 'Roma person' is, nor a generally agreed method of identification as belonging to this group ${ }^{4}$. As such, both self-identification (the person him- or herself declares his/her ethnicity) and hetero-identification (someone else identifies the person in question as being Roma based on various characteristics of the person, including skin colour, kinship, family name, clothing, language spoken, occupation) are accepted. This lack of agreement leaves room for a large number of 'attributional' errors, which might reflect negatively on Roma persons both as individuals and as a group. Among those that could affect Roma persons as individuals, we point out just two: (1) erroneous hetero-attribution of Roma ethnicity, followed by subsequent discrimination based on negative stereotypes; and (2) deceitful self-identification as Roma by a non-Roma person motivated by accessing Roma-dedicated support schemes (for example, reserved places in universities). Among those that could affect Roma persons as a group, we point to the fact that the correct use of the EU funds for the improvement of the life situation of Roma persons becomes difficult to monitor (and prove) when the definition of the target group itself is problematic. In this case, it is a strong moral compass, and not an effective monitoring apparatus, that prevents an EU grant beneficiary from streaming the grant-funded activities towards other target groups that are vulnerable enough to self-identify as Roma even though they are not Roma.

Persons with disabilities are equally discriminated against, both when it comes to visible forms of discrimination (segregated education and limited access to the labour market) and to more subtle forms (physical, psychological, and social barriers). In this volume we argue that this discrimination might be rooted in understandings of disability as such. Before the 1970s, the 'medical model' of understanding disability dominated. This model placed the problem firmly with the individual, and measures were medical or rehabilitational. However, a major shift in thinking took place in the 1960s, initially in the United States, with the 'independent living movement' (Council of Europe, 2010). The paradigm shift implies that disability as a phenomenon is constructed through structural barriers in society. This understanding of disability is referred to as the Social Model, and researchers within the disability research field contributed to developing this model further (Oliver, 1996; Corker and Shakespeare, 2002; Mercer and Barnes, 2003; Shakespeare, 2006). The social model was also taken into account in the WHO's definition of disability, which is the main definition used in the EU. The UN Convention on the Rights of Persons with Disabilities (2006) states that 'disability is an evolving concept and that disability results from the interaction between persons with impairments and attitudinal and environmental barriers that hinders their full and effective participation in 
society on an equal basis with others'. Researchers have pointed out that this understanding also opens the way for seeing the individual and collective disadvantages suffered by people with disabilities as mainly a result of a complex form of institutional discrimination that is as deep-seated in our society as are sexism and racism (Oliver, 1996; Barnes and Mercer, 2003; Ralph et al., 2016). The objectives of the European Disability Strategy 2010-2020 are pursued by actions in quite a number of priority areas. In addition to education, training, and employment, the EU commission also focuses upon social protection, health, and participation. For the purpose of this book, it is also worth noticing that a specified action is the Disability Strategy external action, which is defined as an action aimed to "promote the rights of people with disabilities in the EU enlargement and international development programmes' (EU Commission, 2012). Reports and research show that disabled people in Europe remain consistently disadvantaged in terms of employment, education, and social inclusion (Waddington, 2018). At only 47 per cent, the employment rate of people with disabilities remains much lower than that of people without disabilities (72.5 per cent). About 30 per cent of people with a disability are at risk of poverty or social exclusion in the EU, compared to 21.5 per cent of people without disabilities. The economic crisis from 2008 and onward has also hit people with disabilities across the EU hard (Eurostat, 2015).

In this volume we have invited experts in this field of research to contribute to an anthology in which each chapter describes and analyses the implementation of EU inclusion policies in former communist countries. The analyses provided by the contributors are of two types:

1 Top-down, providing descriptions and interpretations of national-level controversies, debates, and negotiations around the design and implementation of the policies in relation to social inclusion of disadvantaged populations; and

2 Bottom-up, presenting and analysing the transformations produced by the shift of the social inclusion paradigm in the field experiences of various practitioners directly involved in the provision of support for disadvantaged populations.

There are 12 chapters in this edited volume, including contributions from six post-socialist countries - Romania, Poland, Serbia, the Slovak Republic, Hungary, and Bulgaria. In the second chapter of this volume, Teodor Mladenov and Gabor Petri follow closely the approach used by the post-socialist countries in Central and Eastern Europe to incorporate the social model of disability and the independent living philosophy promoted by the UN Convention on the Rights of Persons with Disabilities. Combining a top-down perspective of regional policy formation with a micro-level one of local policy documents, agencies, and practices, they discuss the steps taken in Bulgaria and Hungary to align with the EU ambition of ensuring the right of disabled people to independent living and community inclusion. 
Challenging the presupposition that policy ideas are universally applicable and independent of context, in the third chapter Tijana Morača and Paul Stubbs pursue the active role of the local institutional actors in reshaping policy forms on the ground. Using the case study of a Roma child-inclusion project implemented in Serbia, their chapter focuses on understanding the social life of Roma inclusion policy and the significance of dichotomies between 'central' and 'local' scales and between 'state' and 'non-state' actors.

In the fourth chapter, Joanna Kostka explores the reasons for the modest outcomes of the inclusion projects for the Roma population, developed through the European Social Fund. Based on empirical evidence from Slovakia, she uses a constructivist approach to policy-making to show that the implementation of the Social Fund does not necessarily follow a rational comprehensive model. She argues that the cohesion policy comes with a built-in representation of 'the problem', which in turn strongly influences the implementation process and its outputs.

In the fifth chapter, Andras L. Pap focuses on how Hungarian legislators have conceptualized the Roma as a national minority since the country's political transition from communism in 1989. He argues that Hungary's inconsistent labelling of the Roma people as an ethnic, racial, and national minority reflects in practice the lack of clear conceptualization of the appropriate policy approach towards this group, namely whether a social inclusion, anti-discrimination, or a cultural rights-oriented approach should be used.

Johans Tveit Sandvin and Teodor Mircea Alexiu debate the poor implementation of disability inclusion policies in Romania in the sixth chapter. Giving an introduction to the gap between the country's official policies and the actual situation on the ground, the chapter portrays the problems of adapting to social policies and regulations that are initiated by the EU's central legislative bodies.

Ryszard Szarfenberg discusses the Europeanization of social policies in the seventh chapter by discussing EU social inclusion policy implementation in Poland in a long-term perspective. By analysing adopted and proposed legal acts and soft law documents, he gives a description of institutional dynamics in place during the time span from 1989 to 2018.

In the eighth chapter, Alexandra Strážnická uses the right to vote as a case in point to illustrate the gap between the rights granted by the law and the abilities to exercise these rights in practice by persons with disabilities in the Slovak Republic. In her assessment of this specific right to political participation, she considers both the 'access to' and the 'accessibility of' political activities for people with disabilities.

Urszula Bronisz, Andrzej Jakubowski, Magdalena Miszczuk, and Andrzej Miszczuk give an introduction to social economy and its potential in advancing social inclusion in the ninth chapter. They argue that social economy has the potential capacity to secure employment and sustainable growth, while dealing with challenges such as health care and education. The authors assess the potential of the social economy sector in Poland and its contribution to the promotion of social inclusion after becoming a member of the EU. 
Gábor Szüdi and Jaroslava Szüdi, in the tenth chapter, debate the 'Teach for Slovakia' programme, which is a teaching programme designed to advance equality among students and study outcomes. The chapter gives an introduction to the Slovak school system and its shortcomings when it comes to providing equal opportunities for all groups of students. Utilizing both quantitative and qualitative data in a case study on the 'Teach for Slovakia' programme, the authors give an introduction to how this programme works and to how actors involved have experienced it.

Theofild-Andrei Lazăr and Melinda Dincă discuss, in the eleventh chapter, how people with Roma background in Romania can be included in the labour market. They argue that using the 'integrated approach' is one way of accomplishing this task. The chapter starts out by giving an outline on the challenges people with a Roma background face on the labour market in Romania today, and it moves on to discuss how the integrated approach can be one possible way of overcoming such problems.

In the final chapter, the editors identify and discuss similarities across different post-socialist EU countries represented in this volume, in regard to implementation challenges and how they are dealt with. We argue that there are similar challenges across post-socialist EU states, shaped by common political and social features. The features are partly about how the policy itself constructs inclusion issues at the national level, and partly about challenges in the actual implementation processes and forming of local welfare practices. Challenges at the local level may be understood in light of the fact that social services only play a very small role in the total state welfare funding of the CEE countries, and of weak civil society organization. Also, implementing EU inclusion policy requires a local service apparatus that many post-socialist countries have not yet established.

\section{Notes}

1 However, we should mention that there are scholars who have advanced the idea of an 'East-European social model' (Neesham and Tache, 2010), or a 'catching-up European submodel' (Socol, et al., 2010), comprising two or more welfare regime subtypes.

2 The exonym 'Gypsy', although highly popular until recently (equally among scholars and policy-makers), was discarded for its negative connotations and what became a derogatory use, and replaced instead with 'Roma' as an umbrella term for an otherwise heterogeneous group that includes: Roma, Sinti/Manush, Cale, Kaale, Romanichals, Boyash/Rudari; Balkan Egyptians (Egyprians and Ashkali); Eastern groups (Dom, Lom, Abdal); Travellers, Yenish, populations designated under the administrative term 'Gens du voyage'; as well as persons who identify themselves as Gypsies (Council of Europe, Roma and Travellers team - www.coe.int/en/web/portal/roma/). These subgroups are geographically dispersed, and have different traditions, cultures, languages, and religions, as well as divergent levels of education and socioeconomic status (McGarry, 2012).

3 Something that sets Roma apart from other ethnic minorities in Europe is the absence of a kin state (McGarry, 2012).

4 Partly because Roma persons lack a kin state that could issue appropriate documentation to provide proof of belongingness. 


\section{References}

Ansell, C., Sørensen, E., and Torfing, J. (2017). Improving policy implementation through collaborative policymaking. Policy \& Politics 45(3), pp. 467-486.

Bailyn, J.F., Jelaca, D., and Lugaric, D. (eds.) (2018). The Future of (Post)Socialism. Eastern European Perspectives. Stony Brook, NY: SUNY Press.

Barnes, C. and Mercer, G. (2003). Disability. Cambridge: Polity Press.

Borrás, S. and Radaelli, C.M. (2010). Recalibrating the Open Method of Coordination: Towards Diverse and More Effective Usages, Report No. 7. Stockholm: Swedish Institute for European Policy Studies.

Byrne, D. (2005). Social Exclusion (2nd edition). UK: McGraw-Hill Education.

Castells, M. (1998). End of Millennium: The Information Age: Economy, Society, and Culture. Oxford: Blackwell Publishers.

Corker, M. and Shakespeare, T. (2002). Disability/postmodernity. Embodying Disability Theory. London: Continuum Publishing.

Council of Europe (2010). Disability and disablism. www.coe.int/en/web/compass/disabilityand-disablism?p_p_id=coepdfexport_WAR_coepdfexportportlet\&p_p_lifecycle $=2 \& p \_p \_$ state $=$ normal\&p_p_mode $=$ view\&p_p_cacheability $=$ cacheLevelPage\&_coepdfexport_ WAR_coepdfexportportlet_currentURL $=\mathrm{https} \% 3 \mathrm{~A} \% 2 \mathrm{~F} \% 2 \mathrm{Fwww} . \operatorname{coe}$. int $\% 2 \mathrm{Fen} \% 2 \mathrm{Fweb}$ $\% 2$ Fcompass $\% 2$ Fdisability-and-disablism.

Council of Europe (2012). Estimates on Roma population in European countries (downloadable table). Roma and Travellers Team, accessed online at www.coe.int/en/web/ portal/roma/ [15 November 2018].

de la Porte, C. and Pochet, P. (2012). Why and how (still) study the Open Method of Coordination (OMC)? Journal of European Public Policy 22(3), pp. 336-349.

deLeon, P. and deLeon, L. (2002). Whatever happened to policy implementation? An alternative approach. Journal of Public Administration Research and Theory 12(4), pp. 467-492.

Ellison, N. (2006). The Transformation of Welfare States? London: Routledge.

Esping-Andersen, G. (2002). Why We Need a New Welfare State. Oxford: Oxford University Press.

European Commission (2010). European Disability Strategy 2010-2020: A renewed Commitment to a Barrier-Free Europe. Brussels, European Commission.

European Commission (2012). https://ec.europa.eu/europeaid/sites/devco/files/guidedisability-inclusive-development-cooperation-2012_en.pdf.

European Union Agency for Fundamental Rights (2017). Second European Union Minorities and Discrimination Survey (EU-MIDIS II). Main results. Luxembourg: Publications Office of the European Union, accessed online at https://ra.europa.eu/en/ publication/2017/eumidis-ii-main-results.

Eurostat(2015).https://ec.europa.eu/eurostat/statistics-explained/index.php?title=Disability_ statistics introduced.

Fenger, H.M. (2007). Welfare regimes in Central and Eastern Europe: incorporating postcommunist countries in a welfare regime typology. Contemporary Issues and Ideas in Social Sciences 3(2), pp. 1-30.

Fraser, N. (1998). From redistribution to recognition? Dilemmas of justice in a 'postsocialist' age. In: K. Olson (ed.), Adding Insult to Injury: Nancy Fraser Debates Her Critics. London: Verso.

Hjern, B. and Hull, C. (1982). Implementation research as empirical constitutionalism. European Journal of Political Research 10, pp. 105-115. 
Huxley, P. (2015). Introduction to 'indicators and measurement of social inclusion'. Social Inclusion 3(4), pp. 50-51.

Kuitto, K. (2016). Post-communist Welfare States in European Context. Patterns of Welfare Policies in Eastern Europe. Cheltenham: Edward Elgar Publishing.

Lipsky, M. (1980). Street Level Bureaucracy. Dilemmas of the Individual in Public Services. New York: Russel Sage Foundation.

Marlier, E. and Natali, D. (eds.) (2010). Europe 2020. Towards a More Social EU? Brussels: PIE-Peter Lang.

Matland, R.E. (1995). Synthesizing the implementation literature: the ambiguity-conflict model of policy implementation. Journal of Public Administration Research and Theory 5(2), pp. 145-174.

McGarry, A. (2012). The dilemma of the European Union's Roma policy. Critical Social Policy 32(1), pp. 126-136

Mercer, C. and Barnes, G. (2003). Disability. London: Polity Press.

Migheli, M. (2016). Behind the Wall: What remains of the 'communist legacy' in contemporary Europe. Social Indicators Research 127(2), pp. 671-690.

Neesham, C. and Tache, I. (2010). Is there an East-European social model? International Journal of Social Economics 37(5), pp. 344-360.

Offe, C. (2010). Lessons learned and open questions. Eurozine, 28 January 2010. www. eurozine.com/lessons-learned-and-open-questions.

Oliver, M. (1996). Understanding Disability. From Theory to Practise. London: Palgrave Publishing.

Orenstein, M.A. (2008). Out-liberalizing the EU: pension privatization in Central and Eastern Europe, Journal of European Public Policy 15(6), pp. 899-917.

Pew Research Center (2018). Eastern and Western Europeans Differ on Importance of Religion, Views of Minorities, and Key Social Issues. Research report released 29 October, accessed online at: www.pewforum.org/2018/10/29/eastern-and-westerneuropeans-differ-on-importance-of-religion-views-of-minorities-and-key-social-issues/ [15 November 2018].

Pierson, P. (2004). Politics in time. History, Institutions and Social Analysis. Princeton and Oxford: Princeton University Press.

Polese, A., Morris, J., Kovács, B., and Harboe, I. (2014). 'Welfare states' and social policies in Eastern Europe and the former USSR: where informality fits in? Journal of Contemporary European Studies 22(2), pp. 184-198.

Pressman, J.L. and Wildavsky, A. (1984). Implementation. How Great Expectations in Washington are Dashed in Oakland; Or, Why It's Amazing That Federal Programs Work at All, This Being a Saga of the Economic Development Administration as Told by Two Sympathetic Observers Who Seek to Build Morals on a Foundation of Ruined Hopes, 3rd edn. Berkeley: University of California Press.

Priestley, M. (2003). Disability. A Life Course Approach. Cambridge: Polity Press.

Profiroiu, M. and Profiroiu, A. (2006). Decentralization process in Romania. Transylvanian Review of Administrative Sciences 16E, pp. 115-123.

Pupovac, O. (2010). Present perfect, or the time of post-socialism. Eurozine, 12 May.

Ralph, S., Capewell, C., and Bonnett, E. (2016). Disability hate crime: persecuted for difference. British Journal of Special Education October, 43(3), pp. 215-232.

Rasell, M. and Jarskaia-Smirnova, E. (2014). Disability in Eastern Europe and the Former Soviet Union: History, Policy and Everyday Life. London: Routledge. 
Rogge, N. and Konttinen, E. (2018). Social inclusion in the EU since the enlargement: progress or regress? Social Indicators Research: An International and Interdisciplinary Journal for Quality-of-Life Measurement 135(2), pp. 563-584.

Romano, S. (2014). The Political and Social Construction of Poverty. Central and Eastern European Countries in Transition. Bristol: Policy Press.

Roper, S.D. (2000). Romania: The Unfinished Revolution (Postcommunist States and Nations) (1st edition). Routledge: London and New York.

Roulstone, A. and Barnes, C. (2005). Introduction. In: A. Roulstone and C. Barnes (eds.), Working Futures. Disabled People, Policy and Social Inclusion. Bristol: Policy Press.

Shah, S. and Priestley, M. (2011). Disability and Social Change: Private Lives and Public Policies. Bristol: Policy Press.

Shakespeare, T. (2006). The social model of disability. In: L.J. Davis (ed.), The Disability Studies Reader. London: Psychology Press. pp. 2-197.

Sobotka, E. and Vermeersch, P. (2012). Governing human rights and Roma inclusion: can the EU be a catalyst for local social change? Human Rights Quarterly 34(3), pp. $800-822$.

Socol, C., Marinas, M., and Socol, A.G. (2010). Fiscal sustainability and social cohesion. Common and specific in eu sub-models. Theoretical and Applied Economics XVII 3(544), pp. 43-62.

Treib, O., Bähr, H., and Falkner, G. (2007). Modes of governance. Towards a conceptual clarification. Journal of European Public Policy 14(1), pp. 1-20.

Trnka, S. and Trundle, C. (2014). Competing responsibilities: moving beyond neoliberal responsibilisation. Anthropological Forum 24(2), pp. 136-153.

Trubek, D.M. and Trubek, L.G. (2005). Hard and soft law in the construction of social Europe: the role of the open method of co-ordination. European Law Journal 11(3), pp. 343-364.

Waddington, L. (2018). Disability Assessment in European States. ANED Synthesis Report. 


\title{
Independent living in Central and Eastern Europe? The challenges of post-socialist deinstitutionalization
}

\author{
Teodor Mladenov and Gabor Petri
}

\section{Introduction}

This chapter discusses efforts to realize the right of disabled people to independent living and community inclusion in the post-socialist Central and Eastern European (CEE) region. This right has been stipulated in Article 19 of the United Nations Convention on the Rights of Persons with Disabilities (CRPD), and its realization has been strongly associated with the discourses, agencies, and practices of deinstitutionalization (DI). Since its coming into force in 2008, the CRPD has been formally accepted through its ratification as the legal standard in disability policy-making by most countries around the world, including by the European Union (EU). The CRPD incorporates the social model of disability and the independent living philosophy in an ambitious attempt to legislate removal of disabling barriers, including institutional confinement. The latter is enshrined in Article 19 of the CRPD, titled 'Living independently and being included in the community', which recognizes 'the equal right of all persons with disabilities to live in the community, with choices equal to others'.

The reform of DI has been key for realizing the right codified in Article 19. Rooted in the disabled people's movement (Ratzka, 1996; Evans, 2002), the anti-psychiatry movement (Mansell et al., 2007: 1), the movement of mental health service users (Beresford, 2012), historical and social-scientific critiques of institutional life (Goffman, 1974; Foucault, 2006), and the approach of 'normalisation' (Duffy, 2010), DI has meant the closure of residential institutions for disabled people and their substitution with services in the community. However, in actual policies and practice, DI has often been reduced merely to the dismantling of large settings (EEG [European Expert Group], 2012: 27), a misappropriation of the term that has either disregarded the development of community alternatives or has construed DI as a process of replacing large institutions with small ones located in the community (Duffy, 2011). To avoid such misappropriations, recent analyses and policy guidelines have sought to replace the term 'DI' with more descriptive and process-oriented terms such as 'transition from institutional to community-based care' (EEG, 2012). In our present investigation, we retain the original term because of its brevity, familiarity, and critical energy - DI 
implies discontinuous change through negation, whereas 'transition from institutional to community-based care' implies continuous change through modification.

The reform of DI is of paramount importance in post-socialist CEE states not least because most of the countries in the region have the highest numbers of disabled people living in residential institutions in Europe, while communitybased services remain largely missing (Mansell et al., 2007; Turnpenny et al., 2018). The reasons for this are complex and historically conditioned by state socialist pasts, post-1989 transformations, and more recent processes of EU integration. To tackle this complexity, in this chapter we make use of disability studies, studies of post-socialism, content analysis of policy documents, and case studies from two post-socialist countries, Hungary and Bulgaria. The latter makes our analysis limited in its empirical scope - nevertheless, we intend to offer insights into broader trends of policy formation in the post-socialist CEE region. To this end, we have used several different research methods.

\section{Methods}

We explore the challenges of post-socialist DI by combining a macro-level, topdown study of regional policy formation with a micro-level, bottom-up investigation of local policy documents, agencies, and practices. We consider this mix of perspectives to be essential for critical engagement with disability policy reform in the CEE region because it allows us to uncover general patterns while also taking into account their specific articulations on the ground. In our macrolevel analysis of policies, we consider historical and structural factors impacting on DI reform in CEE countries by referring to state socialist legacy, postsocialist neoliberalization, and EU membership. The pitfalls of deterministic thinking predating such large-scale considerations are mitigated by paying heed to local policies and agencies.

Our micro-level investigations include studying domestic policy documents and mobilizations. We apply the tools of content analysis, broadly conceived which is a widely used method in qualitative social scientific research (Berg, 2004; Hsieh and Shannon, 2005) - to reveal ways in which general historical and structural factors have been transformed into specific policy prescriptions concerning independent living and DI in Hungary and Bulgaria. Thus, we appraise policy documents such as domestic strategies and legislation that are constantly reviewed and reflected upon by both external actors such as the EU and internal actors like civil society groups and organizations. More specifically, we analyse the content of some key provisions in the Hungarian Social Act 1993/3, the Hungarian Government's Deinstitutionalization Strategy for 2011-2041, and the Bulgarian Social Assistance Act of 1998 and the regulations regarding its implementation.

Our analysis of policy documents is complemented by case studies of domestic mobilizations in support of the right of disabled people to live independently and to be included in the community. Case study methodology allows 
one to focus on a unit of data while making broader conceptual observations (Gerring, 2004), thus combining particularistic, descriptive, and heuristic approaches to a given topic (Merriam, 2009: 43-44). That said, a major limitation of case studies is their restricted generalizability (Flyvbjerg, 2006) - a limitation that, in the present analysis, is mitigated through macro-level inquiry into historical and structural forces shaping DI reform in post-socialist CEE countries.

We begin by discussing the genealogy of present-day disability policy in CEE countries, tracing its features to constructions of disability under state socialism and their subsequent modifications (rather than erasure) by the neoliberal transformations that followed the events of 1989. We then consider the mixed impact of EU accession and attendant integration on DI reform in the region over the last 15 to 20 years. In the second part of the chapter, we analyse disability policy documents from Hungary and Bulgaria and we develop case studies of domestic campaigns and other initiatives. The conclusion formulates strategies for moving ahead with DI in such a way that the provisions of Article 19 of the CRPD can effectively be realized in practice, and independent living for disabled people in CEE countries can become a reality. Drawing on Nancy Fraser (1995), we argue that such a development necessitates a shift from 'affirmative' to 'transformative' approaches to social change in the disability area.

\section{Genealogy of disability policy in CEE countries}

Present-day disability policy in CEE countries has been strongly shaped by the legacy of state socialism - a social, political, and economic system that emerged in Russia in the aftermath of the October Revolution of 1917, spread throughout Eastern Europe in subsequent decades, and disintegrated at the end of the 1980s (Lane, 1996). Although state socialism was presented by its proponents as a radical alternative to capitalism, its approach to disability was strikingly similar to the one embraced by capitalist countries in the first half of the twentieth century. ${ }^{1}$ State socialism defined disability as a medically identifiable inability to work and, on this basis, regulated the access of disabled people to public support in cash and in services. This medical-productivist understanding of disability underpinned the proliferation of segregated facilities such as residential institutions for social care (Mladenov, 2018).

The central management of state socialist economies made it possible to allocate significant resources to the building of an extensive infrastructure of residential institutions for social care, routinely located in remote areas to hide disability from public view (Holland, 2008; Phillips, 2009). The sheer materiality of the institutional approach, buttressed culturally by its medical-productivist legitimation, made it very difficult to dismantle or reform residential institutions. This approach survived the demise of state socialism, and decades after 1989 it has continued to be a major source of injustice by channelling disability support in the post-socialist countries of the CEE region along the lines of segregation, confinement, and stigma (Mladenov, 2018). 
Since the 1990s, the CEE post-socialist countries have been subjected to neoliberal reforms introduced widely but unevenly throughout the region (Dale, 2011). Neoliberal retrenchment of public services and social security, deregulation, and privatization of state enterprises have reduced many people in the region to poverty. One way to cope has been to seek help from disability benefits (it is important to note here that poverty itself produces impairments). In effect, the number of claimants has risen. For example, in Hungary during the 1990s, the number of people living on 'disability pension' (under the official retirement age) rose from approximately 240,000 in 1990 to over 460,000 in 2003, on the eve of Hungary's EU accession (Kozponti Statisztikai Hivatal, 2013). Such an increase was also seen in Bulgaria, where, between 2000 and 2010, public expenditures on 'invalidity pensions' increased more than six-fold (Aleksiev, 2012: 4). A vicious circle has emerged - the welfare state has been shrunk, and this (ironically) has forced the welfare state to spend more and more on disability benefits.

Such spending has been largely inefficient. Instead of distributing adequate amounts based on individual needs to those who are disabled while ensuring that all people (disabled and non-disabled alike) have an adequate standard of living that does not make the disability category a condition for survival, post-socialist states have distributed small amounts to an ever-increasing number of people claiming disability status, some of whom have been disabled (including by poverty) while others have been merely poor. As argued by Stone (1984), the distinction between 'disabled' and 'able-bodied' is political, economic, and historical - in times of strong welfare-state arrangements, there is less need to make recourse to the disability category in order to cope with life and to escape poverty and exploitation. However, the distinction becomes more contested and, accordingly, more violently policed in times of economic turmoil and welfarestate retrenchment (see also Roulstone, 2015).

As a result of neoliberal cuts, the living conditions of institutional residents worsened. In his analysis of disability policy in post-Soviet Russia, Fröhlich (2012: 378) observed the following:

Over the course of the social transformations in the 1990s, the Russian social security system faced rapid changes as a result of declining financial and structural resources, and the social situation of people with disabilities became precarious. During the fall of the Soviet Union, the living conditions in state-run residential institutions collapsed.

Available evidence points towards similar patterns of degradation of the living conditions inside socialist-era residential institutions in other post-socialist CEE countries in the aftermath of 1989 (Tobis, 2000; World Bank, 2003). In the European Court of Human Rights (ECHR) case of Stanev v. Bulgaria (no. $36760 / 06, \S 20$, ECHR 2012), the description, which reflects the situation in an old-type institution for 'adults with mental disorders' in Bulgaria during the 2000s, is particularly revealing: 
[T] he buildings did not have running water. The residents washed in cold water in the yard and were often unshaven and dirty. The bathroom, to which they had access once a week, was rudimentary and dilapidated.... The toilets, likewise located in the yard, consisted of decrepit shelters with holes dug in the ground. They were in an execrable state and access to them was dangerous. Furthermore, basic toiletries were rarely available.

At the same time, disabled people living outside institutions (locked in their homes because of a general lack of community services) have been plunged, together with their relatives, deeper and deeper into poverty, which has made them seek institutional care: '[T]he extreme poverty faced by families in Eastern and Central Europe means that families are given few alternatives but institutionalisation of their family member' (Inclusion Europe and Inclusion International, 2005: 4). In the aftermath of the financial crisis of 2008, welfare budgets have been subjected to additional cuts (Hauben et al., 2012), which have further increased the misery of those at the receiving end of 'social care' policies. But besides neoliberal retrenchment and austerity, there have been other important external and internal factors that have impacted on contemporary disability policy in the CEE region.

\section{The role of the EU}

It was policy pressure and funding from the EU that provided the major impetus and public resources to start the process of DI in CEE countries in the late 2000s (Estonia, Latvia, Lithuania, Poland, Czech Republic, Slovakia, Hungary, and Slovenia joined the EU in 2004, Bulgaria and Romania joined in 2007, and Croatia joined in 2013). As Phillips (2012: 35) points out in her study of the implications of EU candidacy and accession on disability rights and policies in Bulgaria, Romania, Croatia, and Macedonia, '[i]n many cases, reform is not "home grown" or internally generated but rather is carried out in reaction to external expectations and funding. This means that commitment may be low and measures incomplete.' The EU's acquis communautaire influenced the adoption of new disability rights legislation across the region, while the EU's structural funds were made available to CEE members for projects aiming at the social inclusion of disabled people, which included DI and the development of various forms of support in the community.

The impact of these new legislative and financial frameworks on post-socialist disability policy has been mixed. On the ground, EU funds have often been allocated to refurbish old residential institutions or to build new ones. As we have argued elsewhere (Mladenov and Petri, under review), such outcomes of EU-promoted DI reforms have contradicted the aims formulated in official documents like the EU Disability Strategy 2010-2020 (European Commission, 2010) - and domestic efforts at DI have often generated reinstitutionalizing policies and practices (Parker et al., 2016, 2017). The very discourse on DI, generated by 
EU bodies and international non-governmental organizations, has manifested Europe-wide power imbalances impeding the genuine transition from institutions to community living. At the EU level, DI reform has been framed by a number of policy documents whose tracking and deciphering requires proficiency in EU governance and international law, which in itself could be a barrier to effective engagement with EU policy-making by disabled advocates and self-advocates (Petri et al., 2017).

Consider this bricolage: presently, the key EU documents on DI include the European Disability Strategy 2010-2020 (European Commission, 2010), which has committed the EU to 'promote the transition from institutional to community-based care'; the EU Regulation on the European Structural and Investment Funds (ESIFs), known as Regulation (EU) No 1303/2013, which requires certain 'ex ante conditionalities' to be fulfilled before the member states can receive funding through the ESIFs - with regard to DI, such a condition is that selected states (including all post-socialist CEE member states) should include in their national poverty reduction strategies 'measures for the shift from institutional to community based care'; the European Commission's Draft Thematic Guidance Fiche for Desk Officers: Transition from Institutional to Community-based Care (Deinstitutionalisation - DI) of January 2014, which clarifies the meaning of the aforementioned conditionality in the sense that the states should plan measures for the development of services in the community to enable independent living; the European Commission's Report on the Implementation of the UN Convention on the Rights of Persons with Disabilities (CRPD) by the European Union of June 2014, which states that the EU should support only those actions that help with independent living and that measures contributing to further institutionalization should not be supported by the ESIFs; and the EU Ombudsman's report Decision of the European Ombudsman Closing Her Own-Initiative Inquiry OI/8/2014/AN Concerning the European Commission of May 2015, which openly criticizes the use of ESIFs in support of institutionalization and provides recommendations for changes.

The content of these documents is highly specialized, privileging people who have mastered the juridical and/or administrative language of EU policy-making, thus reproducing the notorious gap between EU governance and the everyday concerns of EU citizens. In many cases, local disability rights activists have either been co-opted or estranged by what has become a legal/technocratic approach to pursuing disability rights advocacy, and particularly DI (Petri et al., 2017). The effect on local publics has been that DI and other disability rights reforms have been delegitimized as 'Western stuff', with such misperceptions being amplified by populist governments (Hungary being a prominent, if not an isolated, example). ${ }^{2}$

\section{Domestic policy formation}

Gaps between EU policies and CRPD-defined standards on DI on the one hand and domestic policy formation in post-socialist CEE countries on the other can 
be exemplified by analysing changing definitions of 'supported living' in Hungary. Supported living is understood in EU policy guidelines as an important community-based service on par with personal assistance and accessible housing: '[I]n supported living people can choose who they want to live with, in housing that they own or rent. They also receive personnel support from agencies that do not control the accommodation' (EEG, 2012: 94). However, the current use of the term 'supported living' (in Hungarian: támogatott lakhatás) in the Hungarian Social Act 1993/3 is markedly different from this understanding. The term itself had been largely unknown in Hungary until the late 2000s when, following Hungary's ratification of the CRPD in 2008, various disability advocacy initiatives started to push for DI. ${ }^{3}$

It was only in 2013 that the amendment of the Social Act established 'supported living' as a new service category for disabled people, including people with psychosocial impairments. The amendment of the then 20-year-old Social Act in 2013 followed the development of the Hungarian Government's Deinstitutionalization Strategy for 2011-2041, which claimed to reflect the international 'paradigm shift' in disability policy, as represented by the CRPD:

In this Strategy, we avoid all residential provisions that offer segregated and compound living for disabled people where they are unable to exercise control over their own lives. Supported living is a type of social service where people live in the community in a property average in its quality and size; the service must ensure that residents decide on as many aspects of their lives as possible and that they live as members of the local community.

(Hungarian Government, 2011)

However, a closer look at the definition of 'supported living', as set out in the Social Act itself, reveals a very different picture. Although this legislation acknowledges that such a service must be provided on the basis of a thorough 'needs assessment' to ensure that it responds to individual needs, it allows for 'supported living' to be offered in residential settings for up to 50 people. This provision is clearly a misappropriation of the term, as defined in EU policy guidelines (EEG, 2012: 94-95). Moreover, it shows how post-socialist DI has co-opted a human rights discourse 'imported' from the EU and CRPD, while maintaining the status quo of old structures.

Similarly, a content analysis of relevant Bulgarian legislation reveals that the flaws of Bulgarian DI (CIL, 2013; Deneva and Petrov, 2016) have been enabled by certain legislative provisions that have misrepresented institutional placement as support in the community. Key among these provisions is the problematic definition of 'social services in the community' included in 2002 in the Bulgarian Social Assistance Act of 1998: " "Social services in the community" are services provided in a family environment or an environment close to the family one' (Additional Provisions, Para. 1). For one thing, this definition is too focused on the family, but the bigger issue is that, in combination with defining 'social 
services in the community of a residential type' as 'services which provide an opportunity to live in an environment close to the family one' (Additional Provisions, Para. 1), possibilities are opened up to set up residential care under the guise of community services. The problem is exacerbated in Chapter III ('Social Services'), Art. 36 of the Regulations for the Implementation of the Social Assistance Act, which operationalizes the blanket definitions contained in the Act.

A closer look at the Regulations reveals a long list of services denoted as 'Social services, which are provided in the community' (Art. 36, Para. 2), encompassing subcategories such as 'social services at home', 'day care centres', and 'foster care', but also the subcategory 'social services of a residential type', under which one finds different forms of 'centres for family-type placement' (in Bulgarian: tsentrove za nastanyavane ot semeen tip) and 'sheltered housing' (in Bulgarian: zashtiteno zhilishte). The definition therefore enables policy-makers and practitioners to misrepresent small residential settings as community services ostensibly akin to home-based care or foster care, thus justifying their proliferation or else glossing it over by abusing the EU-promoted discourse on community-based services (EEG, 2012). On the other hand, the service 'personal assistant' (in Bulgarian: lichen asistent) is included under the subcategory 'social services at home', together with 'home care' and 'meal-on-wheels', which effectively erases the fundamental difference between these different forms of individualized support (Deneva and Petrov, 2016: 6) - and it is important here to consider the insistence of independent living advocates that " $[\mathrm{t}]$ he term "personal assistance" cannot be used for service delivery solutions where housing and assistance with the activities of daily living are provided in one inseparable package' (Ratzka, 2004: 3).

The provisions of the Bulgarian and Hungarian legislation, as analysed here, are of pivotal importance for DI reform. Their flaws reflect persistent difficulties with processing the legacy of state socialist constructions of disability over the decades of post-socialist neoliberalization in the aftermath of 1989. Such flaws enable the proliferation of reinstitutionalizing practices under the banner of 'deinstitutionalization' and, moreover, erect definitional barriers to the creation of possibilities for independent living and community inclusion. It is in this domestic policy context that local actors mobilize to seek social change.

\section{Local mobilizations}

It is worth remembering that before becoming an expert-centred and expertcontrolled discourse, European DI was promoted at the grassroots level by disabled activists seeking independent living outside of the confines of institutional walls. For example, in his history of the independent living movement in the United Kingdom, the disabled activist John Evans (2002) recalls numerous local initiatives and international collaborations aimed to create and promote community alternatives to institutional care, and consider also Adolf Ratzka's (1996) 
recollections on independent living activism in Sweden in the 1980s and 1990s. Moreover, such efforts were not limited to Western European countries, although similar initiatives in state socialist Eastern Europe were heavily repressed by the authorities:

[I]t is important to note that the Soviet-era disability rights activism that emerged beginning in the 1960s came out of internaty (see Indolev 1998). This is evidence that, despite their many shortcomings, the internaty had a beneficial if unintended side effect: the close proximity of people with similar experiences, concerns, and grievances allowed a disability rights consciousness to foment. At the same time, however, the tight state control on internaty meant that the rights movements were also squelched there, because the state could easily move people from internat to internat to disrupt social networks.

(Phillips, 2009: n.p.)

It was only after the fall of the state socialist regime at the end of the 1980s that disability rights campaigners were able to organize freely without being directly repressed or else submitted to tight control by the authorities. Some of these advocacy initiatives have promoted systemic change along the lines of independent living and DI, while others have merely attempted to humanize the mechanisms for institutional confinement and segregation inherited from state socialist disability policy.

\section{Past mobilizations}

In Hungary, parents of disabled people have put forward demands for better services in many areas including education, rehabilitation, employment, and daycare since the 1990s. These efforts have been impactful - for example, organizations of parents of autistic people have successfully lobbied subsequent governments for progressive changes in both education and autism diagnosis policies (Balázs and Petri, 2010). However, in the field of community living, parents' organizations focused mostly on the creation and funding of group homes. Indeed, according to leading advocates and government officials, one of the biggest achievements of parents' advocacy in autism in the 2000s was the establishment of several small group homes, each accommodating up to 12 adults (ibid.). Such impact was recognized by officials at the time and was explained with reference to grassroots unity:

One of the reasons why parents' advocacy in autism has been so successful is the fact that AOSZ [Autistak Orszagos Szovetsege - Hungarian Autistic Society, the national umbrella organisation representing families of autistic people] was organised bottom-up, so parent-led organisations were more united than those in other disability groups. 
Despite such positive appraisals, demands for personal assistance schemes or personal budgets did not feature high in parents' advocacy. Instead, parents' organizations, often allied with non-governmental organizations established by professionals, focused much of their lobbying on education and specialized services for children. When asked about services for adults in an empirical study (Kiss, 2010), parents stated that small residential settings such as group homes are appropriate - or for some even ideal - for autistic adults, provided that the residents have their own rooms and access to in-house support like in-house assistants as well as vocational and other types of rehabilitation. Notably, demands for supported living schemes were not made, with many parents stating that their adult-aged children should live with the family until the parents can no longer look after them (Kiss, 2010). ${ }^{5}$

In Bulgaria, the advocacy for independent living and community inclusion began in the middle of the 1990s with the founding of the Bulgarian grassroots disabled people's organization Centre for Independent Living-Sofia (CIL-Sofia). As a user-led, user-controlled, cross-disability initiative, CIL-Sofia has campaigned for more than 20 years for a complete overhaul of the national disability support system. Such campaigns, recorded in numerous reports, analyses, and publications (available at the organization's website: cil.bg), have included demands for the introduction of personal assistance, as well as advocacy for a nationwide transition from institutional to community-based services aligned with EU guidelines and the provisions of the CRPD.

Among the results of these efforts was the adoption of an 'Assistants for Independent Living' scheme by the Sofia Municipality in 2007, which has been implemented at the municipal level since then (Mladenov, 2017). More recently, CIL-Sofia has organized a number of protests, performances, and other public events criticizing domestic DI reforms as 'reinstitutionalizing' because of their over-reliance on small residential settings as substitutes for the big institutions of the past (CIL, 2013; Deneva and Petrov, 2016). However, such advocacy initiatives have remained largely isolated and marginalized because of the reluctance of other Bulgarian civil society organizations to support them, and most importantly because of the (sometimes open) hostility of nationally representative umbrella organizations of and for disabled people towards systemic change (Mladenov, 2009).

\section{Present-day mobilizations}

The strongest, most vocal, and most popular disability-related campaigns in Hungary, Bulgaria, and elsewhere in the CEE region in 2018 targeted neoliberal austerity and its pernicious effects on locally provided disability support. ${ }^{6}$ In Hungary, a campaign was launched in 2018 by a small parental organization, with the objective to raise the allowance of informal caregivers of severely disabled children or adults. Informal caregivers often work 24/7 to support their severely disabled or chronically ill family members, mostly because there are no 
support services in the community. Presently, around 12,000 caregivers work under this 'caregivers allowance' (in Hungarian: ápolási díj) whose monthly amount, even in the highest support category, is only HUF 52,800 (approx. EUR 160) per month. The campaign has aimed to increase this amount significantly and to acknowledge by law that this is not a welfare allowance, but is employment (with ensuing pension and other entitlements).

This initiative gained significant public support, with nearly 40,000 signatures on an online petition (aHang, 2018). An open letter to the minister of social affairs was signed by 41 non-governmental organizations, including disabled people's organizations and online collectives such as parents' online self-help groups. Several demonstrations were held in front of the Parliament building, attended by caregivers, disabled people, and supporters. The largest Hungarian disabled people's organization (core-funded by the state) also supported the campaign, openly criticizing the government's reluctance to improve the situation. Several opposition MPs, including politicians from liberal, far right, and green parties, also supported the campaign and tabled legislative proposals.

A similar campaign took place in Bulgaria, where parents of disabled children took to the streets in Sofia and other cities with demands for legislative codification and public funding for personal assistance for their children. This campaign was launched in June 2018 and, at the time of writing (late September 2018), was still ongoing (Marinova, 2018). It has included several months of protest camping in front of the Bulgarian Parliament under the slogan 'The system kills us', public demonstrations, and heated discussions on Facebook. The media presence of the protesting parents has been very strong and has initiated a nationwide debate on the need to reform disability support (Stoyanova and Stoynova, 2018).

The parents (consistently referred to in the Bulgarian media as 'the mothers') have been supported by the Bulgarian Ombudsman Maya Manolova, who has collaborated with the activists in drafting a new Personal Assistance Bill. However, the nationally representative organizations of disabled people have opposed the campaign and have proposed an alternative legislative reform that, according to the parents, is oriented towards maintaining the status quo (Stoyanova, 2018). Moreover, the Personal Assistance Bill drafted by Manolova and the parents has been criticized by CIL-Sofia because it puts assistants' wages at very low levels and does not restrict the possibility of family members to be employed as assistants. CIL-Sofia has argued that providing support in this way would reduce it to social assistance for families with disabled children (CIL, 2018).

Although anti-austerity campaigns such as those in Hungary and Bulgaria in 2018 testify to the power of local agencies to influence disability policy in postsocialist CEE countries, they are not necessarily conducive to disabled people's independent living. Of note here is that tensions between, on the one hand, the strategy of poverty alleviation and, on the other, advocacy for independent living and social inclusion have plagued the disabled people's movement from its early days. Consider, for example, the famous document 'Fundamental 
Principles of Disability' - a transcript and commentary of a discussion held in 1975 between representatives of two British disability organizations, the radical Union of the Physically Impaired Against Segregation (UPIAS) and the moderate Disability Alliance. ${ }^{7}$ In this discussion, the Alliance defended income substitution for disabled people (a kind of invalidity pension intended to alleviate the poverty of those excluded from gainful employment on the grounds of their impairments), whereas UPIAS insisted on making society (and, particularly, employment) more inclusive for disabled people so that they could gain (economic) independence:

The Union's social theory of disability, itself a product of the technological changes in society, reflects the most advanced developments which make it clear that the alternative to an 'incomes' (or more properly, 'pensions') approach to the particular poverty in disability is to struggle for changes to the organisation of society so that employment and full social participation are made accessible to all people, including those with physical impairments. Setting 'incomes' in the context of this struggle to change the organisation of society, would help physically impaired people recognise the correct emphasis to be placed upon incomes.

(UPIAS, 1976: 15)

Obviously, UPIAS's approach was strongly productivist, influenced by a specific conception of redistribution ('to each according to work contribution' as opposed to 'to each according to need'), but also inflected by the rising scepticism towards the welfare state that would, eventually, morph into the neoliberalization of the 1980s and beyond:

[F]or people of working age financial and other forms of help must above all be geared to the retention or achievement of integrated employment: dependence on the State must increasingly give way to the provision of help so that a living can be earned through employment. Similarly, the assistance given to physically impaired children must be directed towards their progressive integration into ordinary employment.

(Ibid.: 15)

Can we, as disability advocates and analysts from CEE countries, learn something from these early exchanges between Western disability organizations and grassroots activists while retaining our critical distance informed by our own experience and insight into state socialist ableism and the neoliberal dismantling of CEE welfare states post-1989? For example, would it be possible to retain UPIAS's emphasis on independent living and social inclusion while rejecting UPIAS's 'dependency' rhetoric (which eventually became a central argument of neoliberal and neoconservative reformers - see Roulstone and Prideaux, 2012: 81), as well as UPIAS's productivist assertion that for disabled people of 
working age 'financial and other forms of help must above all be geared to the retention or achievement of integrated employment'?

\section{Concluding reflections: from affirmation to transformation}

It seems that recent campaigns for disability reforms in some post-socialist CEE countries have reproduced the approach defended by the Disability Alliance in Britain some four decades ago, without considering the dangers of income support highlighted by UPIAS (1976). Let us consider the cases of Hungarian and Bulgarian parents protesting in 2018 with the help of UPIAS's (1976) analysis, while bracketing the latter's productivist leanings and 'dependency' rhetoric. From such a perspective, increasing (or providing) parental allowances will make families of disabled children less poor, but will not make disabled children more independent or included in society. In the absence of (non-parental) personal assistance and other community services, cemented by legislative misrepresentation of residential settings as 'community services', both the parent (usually the mother) and the child become prisoners of their home, locked out in the realm of the private even when their basic needs such as food, clothing, and shelter are satisfied.

To better understand the situation, we might distinguish between 'affirmative' and 'transformative' redistributive measures, following Nancy Fraser (1995). Paying parents to care for their disabled children exemplifies affirmative redistribution, which amounts to a mere reallocation of resources without changing the underlying mechanisms maintaining disabled people's ableist subjugation (and women's patriarchal oppression). In contrast, developing community services such as supported living or personal assistance could have transformative effects (as far as they are not shaped according to flawed legislative definitions), making disabled children more equal to non-disabled ones (and women freer to explore life outside the home). As Fraser (1995) has suggested, it is not enough to advocate for social and economic rights, and what is needed is to advocate for transformative measures for the achievement of these rights.

From such a perspective, the problem with domestic disability rights mobilization against neoliberal austerity in the post-socialist CEE countries is that they aim exclusively at affirmative redistribution, which in itself is unable to cancel the subordinate position of disabled people in societies that have otherwise remained heavily ableist. Kolářová (2012), in her analysis of a protest against austerity led by disabled people in the Czech Republic in 2011, makes the point that ' $[\mathrm{n}]$ either shaming the government for breaking the consensus of humanism that requires the society to help the misfortunate, nor shaming others for illegitimately claiming such social assistance, will disrupt the structural and institutionalized inequalities that produce disability'. The advantage of transformative measures is that they could potentially disrupt such oppressive structures. 
While they cannot substitute income support and cover the additional costs of living with impairment, measures such as personal assistance, supported living, and accessible housing are indispensable for bringing about social transformation in the disability field. These measures, however, have been missing from existing DI programmes in the CEE region, where DI has been perceived by policy-makers largely in terms of infrastructural investments into new residential facilities without broader policy changes in community services, personal assistance, or housing (Petri and Kozma, 2017; Mladenov and Petri, under review). But without introducing such changes, the post-socialist CEE countries are bound to comply only half-heartedly with the EU's top-down pressures for DI and with the provisions of the CRPD - by refurbishing old facilities and/or building smaller replicas of the large, state socialist residential settings. Meanwhile, disabled people will remain confined in institutions or at home, while independent living will remain abstract, distant, and even menacing 'Western stuff'.

\section{Notes}

1 Besides disability policy, there were other principles, practices, relations, and institutions within state socialism that remained capitalist in their essence. This has prompted some analysts to refer to state socialist societies as 'state capitalist' ones (Tamás, 2011; Debord, 2014). In this chapter, we follow Lane (1996) in sticking to the more conventional term 'state socialism' because it emphasizes key differences from capitalism, including public ownership of the means of production, central economic planning, and an ideological prioritization of collectivism over individualism.

2 Presently, there is a strong backlash against 'human rights' in Hungary, where 'human rights' are associated with 'Western' interference in national sovereignty and are seen as a 'Western' invention intended to 'weaken' Hungary. Similar ideas have been spreading in other CEE countries as well. That said, Western European countries have also witnessed a resurgence of anti-EU and anti-UN sentiments, as exemplified most prominently by 'Brexit' events in the United Kingdom.

3 Notably, at that time DI had already been a recognized policy, set by the Hungarian Equal Opportunities of Disabled People Act of 1998, one of the first 'disability human rights' laws in Europe (Vanhala, 2015). Although this legislation set out DI as a core action, it also allowed for continuity in 'humanized' institutional care for those with high support needs and did not mention 'supported living'.

4 Most of the provisions of this strategy, including the quoted paragraph, have been retained after its partial amendment in 2017.

5 Ironically, Hungarian parents of autistic people refused to fight for the very services that they and their children would need in order to live independently and to be included in the community, demanding instead the creation of new residential settings funded by the state. However, studies also found that parents were reluctant to place their autistic children in existing residential care facilities because they saw such services as ill-prepared to meet autistic people's needs, for example by being understaffed, by requiring residents to share rooms, by lacking organized daily activities for residents, and by employing staff ignorant about the specific needs of autistic people (Kiss, 2010: 191-193). Focus group discussions revealed that most parents considered any residential services, large and small alike, only as a 'last resort' in case their own ill health would prevent them from being able to look after their autistic family member. 
Moreover, the parents of 'high functioning' autistic people were the least likely to consider group homes for their children (Petri and Valyi, 2009). This meant that the higher their children's support needs, the more likely it was that the parents considered residential care as an option, revealing how the lack of alternatives in the community pushed parents in a direction in which they were essentially reluctant to go.

6 For a Polish example, see: www.france24.com/en/20180527-polish-disabled-protesterscall-off-sit-parliament.

7 The document contains the seminal distinction between 'impairment' and 'disability' subsequently used by Michael Oliver (1996) in his formulation of the social model of disability.

\section{References}

aHang (2018). Az otthoni ápolás munka, amelyért munkabér jár!/Caring is work and carers deserve a salary! [online petition] Available at: https://terjed.ahang.hu/ campaigns/apolasidij [Accessed 14 January 2019].

Aleksiev, Y. (2012). Nov podhod kam integratsiyata na horata s uvrezhdaniya v Balgaria./New approach towards the integration of people with disabilities in Bulgaria. [online] Sofia: Institute for Market Economics. Available at: http://ime.bg/var/images/ IME_Integration_2012.pdf [Accessed 14 January 2019].

Balázs, Z. and Petri, G. (2010). Az autizmussal élöket segítő magyarországi civil ellátórendszer kialakulása./Organisations helping people with autism in Hungary and their role in the development of policies and services. In: V. Bognár, ed., Láthatatlanok. Autista emberek a társadalomban./Invisible Autistic People in Society. Budapest: SCOLAR, pp. 36-77.

Beresford, P. (2012). Psychiatric system survivors: an emerging movement. In: N. Watson, A. Roulstone, and C. Thomas, eds., Routledge Handbook of Disability Studies. New York: Routledge, pp. 151-164.

Berg, B.L. (2004). Qualitative Research Methods for the Social Sciences. Boston: Allyn and Bacon.

CIL (2013). Poveche ot sashtoto ili mimikriyata - bolest po sotsialnite uslugi v Balgariya./More of the same or mimicry - a disease of social services in Bulgaria. [online] Sofia: Center for Independent Living - Sofia. Available at: http://cil.bg/userfiles/ Community-Services-Comparative-Analysis-Final.pdf [Accessed 14 January 2019].

CIL (2018). Stanovishte na TsNZh po Zakonoproekta za lichna pomosht, razraboten or Ombudsmana na Republika Balgariya Maya Manolova./Position of CIL on the Personal Assistance Bill drafted by the Ombudsman of the Republic of Bulgaria Maya Manolova. [online] Sofia: Center for Independent Living - Sofia. Available at: http:// cil.bg/\%D0\%9D\%D0\%BE\%D0\%B2\%D0\%B 8\%D0\%BD\%D0\%B8/306.html [Accessed 14 January 2019].

Dale, G. (2011). Introduction: the transition in Central and Eastern Europe. In: G. Dale, ed., First the Transition, Then the Crash. Eastern Europe in the 2000s. London: Pluto Press, pp. 1-20.

Debord, G. (2014 [1967]). The Society of the Spectacle. [Trans. K. Knabb.] Berkeley, CA: Bureau of Public Secrets.

Deneva, N. and Petrov, R. (2016). Zhivot na volya ili po chuzhda volya! Politikata na t. nar. "deinstitutsionalizatsiya" (DI) v Balgariya i posleditsite za pravoto na nezaisim zhivot na horata s uvvrezhdaniya, koito sa obekt na tazi politika./Living free or under 
control! The policy of the so-called 'deinstitutionalisation' (DI) in Bulgaria and the consequences for the right to live independently of people with disabilities targeted by this policy. [online] Sofia: Center for Independent Living - Sofia. Available at: http:// cil.bg/userfiles/nabliudatelnitsa/Report-DI-Final.pdf [Accessed 14 January 2019].

Duffy, S. (2010). The citizenship theory of social justice: exploring the meaning of personalisation for social workers. Journal of Social Work Practice 24(3), pp. 253-267.

Duffy, S. (2011). A fair society and the limits of personalisation. Discussion paper from the Centre for Welfare Reform first presented at the Tizard Memorial Lecture, 4th March 2011. [online] Sheffield: Centre for Welfare Reform. Available at: www.centreforwelfare reform.org/uploads/attachment/261/a-fair-society-and-the-limits-of-personalisation.pdf [Accessed 14 January 2019].

EEG (2012). Common European Guidelines on the Transition from Institutional to Community-based Care. [online] Brussels: European Expert Group on the Transition from Institutional to Community-based Care. Available at: https://deinstitutionalisation. com/eeg-publications/ [Accessed 14 January 2019].

European Commission (2010). 'Communication from the Commission to the European Parliament, the Council, the European Economic and Social Committee and the Committee of the Regions. European Disability Strategy 2010-2020: A Renewed Commitment to a Barrier-Free Europe'. $\operatorname{COM}(2010) 636$ final. Brussels: European Commission. Available at: http://eur-lex.europa.eu/LexUriServ/LexUriServ.do?uri= COM:2010:0636:FIN:en:PDF [Accessed 14 January 2019].

Evans, J. (2002). Independent Living Movement in the UK. [online] Leeds: University of Leeds. Available at: https://disability-studies.leeds.ac.uk/wp-content/uploads/sites/40/ library/evans-Version-2-Independent-Living-Movement-in-the-UK.pdf [Accessed 14 January 2019].

Flyvbjerg, B. (2006). Five misunderstandings about case-study research. Qualitative Inquiry 12(2), pp. 219-245.

Foucault, M. (2006 [1961]). History of Madness. [Trans. J. Khalfa and J. Murphy.] New York: Routledge.

Fraser, N. (1995). From redistribution to recognition? Dilemmas of justice in a 'postsocialist' age. New Left Review 1(212), pp. 68-93.

Fröhlich, C. (2012). Civil society and the state intertwined: the case of disability NGOs in Russia. East European Politics 2(4), pp. 371-389.

Gerring, J. (2004). What is a case study and what is it good for? American Political Science Review 98(2), pp. 341-354.

Goffman, E. (1974 [1961]). Asylums: Essays on the Social Situation of Mental Patients and Other Inmates. Harmondsworth: Penguin Books.

Hauben, H., Coucheir, M., Spooren, J., McAnaney, D., and Delfosse, C. (2012). Assessing the Impact of European Governments' Austerity Plans on the Rights of People with Disabilities. Brussels: European Consortium of Foundations on Human Rights and Disability - Bernhard Brunhes International BPI Group. Available at: www.enil.eu/wpcontent/uploads/2012/12/Austerity-European-Report_FINAL.pdf [Accessed 14 January 2019].

Holland, D. (2008). The current status of disability activism and non-governmental organizations in post-communist Europe: preliminary findings based on reports from the field. Disability \& Society 23(6), pp. 543-555.

Hsieh, H. and Shannon, S.E. (2005). Three approaches to qualitative content analysis. Qualitative Health Research 15(9), pp. 1277-1288. 
Hungarian Government (2011). 1257/2011. (VII.21.) Kormányhatározat a fogyatékos személyek számára ápolást-gondozást nyújtó szociális intézményi férőhelyek kiváltásának stratégiájára./Government Decree on the Strategy for the Deinstitutionalisation of Residential Social Institutions for People with Disabilities. [online] Budapest: Hungarian Government. Available at: http://fszk.hu/wp-content/uploads/2015/06/ Kormanyhatarozat-es-Strategia-a-fogyatekos-szemelyek-szamara-apolast-gondozastnyujto-szocialis-intezmenyi-ferohelyek-kivaltasarol.pdf [Accessed 14 January 2019].

Inclusion Europe and Inclusion International (2005). Poverty and Intellectual Disability in Europe. [online] Brussels: Inclusion Europe. Available at: http://inclusion-europe.eu/wpcontent/uploads/2015/03/SocInc_EUPovertyRreport.pdf [Accessed 14 January 2019].

Kiss, M. (2010). A felnőtt lét peremén./Problems of autistic adults through parents' perspectives. In: V. Bognár, ed., Láthatatlanok. Autista emberek a társadalomban./Invisible Autistic People in Society. Budapest: SCOLAR, pp. 222-258.

Kolářová, K. (2012). Affective politics of disability shame in the times of neoliberal exceptionalism. In: S. Mesquita, M.K. Wiedlack, and K. Lasthofer, eds., ExportImport-Transport: Queer Theory, Queer Critique and Activism in Motion. Wien: Zaglossus, pp. 263-280.

Kozponti Statisztikai Hivatal (2013). A korhatár alatti rokkantsági nyugdijasok föbb jellemzöi, 2001-2011./Status of Disability Pension Claimants 2001-2011. Budapest: Kozponti Statisztikai Hivatal/Central Statistical Office.

Lane, D. (1996). The Rise and Fall of State Socialism. Cambridge: Polity Press.

Mansell, J., Knapp, M., Beadle-Brown, J., and Beecham, J. (2007). Deinstitutionalisation and Community Living - Outcomes and Costs: Report of a European Study. Volume 2: Main Report. Canterbury: Tizard Centre, University of Kent.

Marinova, E. (2018). Maykite na detsa s uvrezhdaniya gotvyat novi efektivni protesti./ The mothers of disabled children plan new effective protests. [online] Investor.BG. Available at: www.investor.bg/ikonomika-i-politika/332/a/maikite-na-deca-s-uvrejdaniiagotviat-novi-efektivni-protesti-268644/ [Accessed 14 January 2019].

Merriam, S.B. (2009). Qualitative Research: A Guide to Design and Implementation. San Francisco, CA: John Wiley \& Sons.

Mladenov, T. (2009). Institutional woes of participation: Bulgarian disabled people's organisations and policy-making. Disability \& Society 24(1), pp. 33-45.

Mladenov, T. (2017). Governing through personal assistance: a Bulgarian case. Scandinavian Journal of Disability Research 19(2), pp. 91-103.

Mladenov, T. (2018). Disability and Postsocialism. London: Routledge.

Mladenov, T. and Petri, G. (under review). Critique of deinstitutionalisation in postsocialist Central and Eastern Europe.

Oliver, M. (1996). Understanding Disability: From Theory to Practice. London: Macmillan.

Parker, C., Angelova-Mladenova, L., and Bulic, I. (2016). Working Together to Close the Gap Between Rights and Reality. A Report on the Action Needed to Ensure That European Structural and Investment Funds Promote, Not Hinder, the Transition from Institutional Care to Community Living. [online] Brussels: European Network on Independent Living - European Coalition for Community Living. Available at: http:// enil.eu/wp-content/uploads/2016/06/Working-Together-to-Close-the-Gap.pdf [Accessed 14 January 2019].

Parker, C., Bulic, I., and Kokic, N. (2017). European Union Structural and Investment Funds and the Transition from Institutional Care to Community Living: Towards a More Effective Monitoring and Complaints System. [online] Brussels: European 
Network on Independent Living. Available at: http://enil.eu/wp-content/ uploads/2017/07/OurRightsCampaign-Briefing_FINAL.pdf [Accessed 14 January 2019].

Petri, G. and Kozma, Á. (2017). Közösségi életvitel és intézményi férőhelykiváltás Magyarországon. Kritikai elemzés./Community living and deinstitutionalisation in Hungary. A critical analysis. Esély 5, pp. 39-63.

Petri, G. and Valyi, R., eds. (2009). Autizmus - Teny - Kepek./Autism - Facts - Snapshots. Budapest: Autistak Orszagos Szovetsege - Jelenkutato Alapitvany.

Petri, G., Beadle-Brown, J., and Bradshaw, J. (2017). 'More honoured in the breach than in the observance' - self-advocacy and human rights. Laws 6(4), pp. 1-20.

Phillips, S.D. (2009). 'There are no invalids in the USSR!': A missing Soviet chapter in the new disability history. Disability Studies Quarterly 29(3), n.p. Available at: www. dsq-sds.org/article/view/936/1111 [Accessed 14 January 2019].

Phillips, S.D. (2012). Implications of EU accession for disability rights legislation and housing in Bulgaria, Romania, Croatia, and the Former Yugoslav Republic of Macedonia. Journal of Disability Policy Studies 23(1), pp. 26-38.

Ratzka, A. (1996). STIL, the Stockholm Cooperative for Independent Living. [online] Stockholm: Independent Living Institute. Available at: www.independentliving.org/ docs3/stileng.html [Accessed 14 January 2019].

Ratzka, A. (2004). Model national personal assistance policy. [online]. Stockholm: Independent Living Institute. Available at: www.independentliving.org/docs6/ratzka200410a.pdf [Accessed 14 January 2019].

Roulstone, A. (2015). Personal Independence Payments, welfare reform and the shrinking disability category. Disability \& Society 30(5), pp. 673-688.

Roulstone, A. and Prideaux, S. (2012). Understanding Disability Policy. Bristol: Policy Press.

Stone, D. (1984). The Disabled State. London: Macmillan.

Stoyanova, T. (2018). Dva protesta na hora s uvrezhdaniya se provedoha pred parlamena./ Two protests of people with disabilities were held in front of the parliament. BNR. Available at: http://bnr.bg/post/101000576/nacionalno-predstavitelni-organizacii-nahora-s-uvrejdania [Accessed 14 January 2019].

Stoyanova, T. and Stoynova, D. (2018). Dostoen zhivot za detsata si poiskaha protestirashtite mayki, obedineni pod mototo 'Sistemata ni ubiva'./Dignified living for their children demanded protesting mother, unified by the slogan 'The system kills us'. BNR. Available at: http://bnr.bg/post/101001838/zapochna-nacionalnoto-protestno-shestviena-maikite-na-deca-s-uvrejdania [Accessed 14 January 2019].

Tamás, G.M. (2011). Marx on 1989. In: G. Dale, ed., First the Transition, then the Crash: Eastern Europe in the 2000s. London: Pluto Press, pp. 21-45.

Tobis, D. (2000). Moving from Residential Institutions to Community-Based Social Services in Central and Eastern Europe and the Former Soviet Union. Washington, DC: World Bank.

Turnpenny, A., Petri, G., Finn, A., Beadle-Brown, J., and Nyman, M. (2018). Mapping and Understanding Exclusion: Institutional, Coercive and Community-based Services and Practices across Europe. Brussels: Mental Health Europe.

UPIAS (1976). Fundamental Principles of Disability. London: Union of the Physically Impaired Against Segregation. Available at: www.leeds.ac.uk/disability-studies/ archiveuk/UPIAS/fundamental\%20principles.pdf [Accessed 14 January 2019]. 
Vanhala, L. (2015). The diffusion of disability rights in Europe. Human Rights Quarterly 37(4), pp. 831-853.

World Bank (2003). Social Development in Europe and Central Asia Region: Issues and Directions. Washington, DC: World Bank. Available at: http://siteresources.worldbank. org/EXTECAREGTOPNGOCIVSER/Resources/Social_Development_Strategy.pdf [Accessed 14 January 2019]. 


\title{
The limits of projects: translating the social inclusion of Roma in Serbia
}

\author{
Tijana Morača and Paul Stubbs
}

\section{Introduction}

Policies often mean one thing in the heads of those who make them and quite another on the ground. The shift, or translation, from one meaning, or set of meanings, to another is far from arbitrary or accidental. Indeed, even the idea of the 'unintended consequences' of policy can conceal as much as it reveals. Exploring the day-to-day dynamics of a Roma inclusion project in Serbia, funded by the European Union (EU) as it extends its own social inclusion policies to aspirant Member States, we address the complexities of the processes through a lens of translation, attentive to 'the shifting, mobile and contested forms that a policy can take as it moves' (Clarke et al., 2015a, p. 34). At the same time, this movement must be seen as 'a deeply politicised process entangled with maintaining and transforming power relations' (ibid., p. 37). At the heart of this chapter, then, is a case study of the way in which abstract policy models, frames, and discourses unfold in, adapt to, and are translated within the 'local' contexts in which they are implemented and, at the same time, how 'localized' practices can 'talk back' and significantly alter those same models.

As a candidate country for accession to the EU, Serbia is meant to be committed to policies that seek to eliminate discrimination and to improve the quality of life of disadvantaged minorities, including Roma. The main focus of the chapter is on the on-the-ground practices deriving from these policies, including projects funded by the EU and implemented by groups in 'civil society', a translation term for non-governmental organizations (NGOs) increasingly enrolled as implementing partners in EU-funded projects. The study of the social life of one particular, but by no means atypical, Roma social-inclusion project in Serbia demonstrates the ways in which policy models, precepts, and discourses unfold in a projectized intervention.

The main purpose of the chapter is to describe and analyse the active and often instrumentalized and pragmatic reformulation of 'Roma inclusion projects' in practice. We demonstrate how the everyday life of a project departs, at times dramatically, from the formal strictures of policy. In the process of doing so, we challenge the myth of context-free, universally applicable policy ideas, and 
instead we seek to understand how policies constitute, and are constituted by, social relations, diverse actors on 'crowded stages', and complex power relations in different locales. We address the contradictory impact of austerity measures on social inclusion practices in the context of a hyperactive reform by focusing on a range of interlinked policy domains. Asymmetries of power are traced across two dimensions - the first being the importance of political party membership in distributing resources and opportunities and the second being the significance of the dichotomies between 'central' and 'local' scales and between 'state' and 'non-state' actors. In this sense, the chapter combines a 'top-down' and a 'bottom-up' perspective, exploring how policies and the intentions behind them change when they are translated into specific group, organizational, and institutional settings 'on the ground'. At the same time, none of this is to suggest that policies as formulated on paper are ideologically innocent and unproblematic.

The next section addresses, in broad terms, the historical underpinnings of social inclusion policies in the EU and their extension to Roma minorities within and beyond EU Member States. A descriptive overview is then provided of the exclusion of Roma in contemporary Serbia and the nature of strategic, political, and practical discourses meant to overcome this. The third section looks more closely at the conceptual and methodological tools for our exploration of the research question, rooted in critical policy studies and, in particular, in theories of 'policy translation'. The use of broadly ethnographic approaches, here understood more as a 'sensibility' than a prescribed method, is also explained. The fourth section of the chapter, the centrepiece of the text, is an ethnographic analysis of key aspects of the Inclusion of Roma Children (IROC) ${ }^{1}$ project observed by one of us (T.M.) as part of research for a doctoral dissertation ${ }^{2}$. The final section discusses some of the implications of the study and draws a number of conclusions.

\section{Roma inclusion in Serbia and the EU}

The concept of 'social exclusion' (exclusion sociale) is widely attributed to René Lenoir, the one-time French Secretary of State for Social Action who, in 1974, referred to a tenth of the French population as 'left behind' as the economy grew and whose exclusion threatened the social cohesion of French society as a whole. Lenoir's tone was very much that of what Levitas (1996) would term a 'moral underclass discourse', blaming the poor for their own fate, referring to 'the mentally and physically handicapped, suicidal people, aged invalids, abused children, substance abusers, delinquents, single parents, multi-problem households, marginal, asocial persons, and other social "misfits", (Lenoir, 1974, cited by Salais, 2003). Over time, the list of the excluded may have widened, but the overall logic remains largely intact.

The misattribution of causality to the excluded themselves is certainly retained, we would argue, as the concept is translated to the context of the EU, 
gaining a dominant position in terms of measuring, describing, analysing, and combating social disadvantage. Over several decades, the European Social Model has focused on the need for active policies to promote 'social inclusion', reaching its apotheosis in the Europe 2020 strategy for 'smart', 'sustainable', and 'inclusive' growth (European Commission, 2010). Although much of what tends to be subsumed within policies to promote social inclusion remains quite firmly in the realm of the EU Member States, the Open Method of Co-Ordination (OMC) has expanded the policy space for other actors, including the European Commission's Directorate General on Employment and Social Affairs (its exact title changing frequently over time), to frame tools, indicators, procedures, and discourses in a way that allows for a 'benchmarking' of progress across, and beyond, the EU, in part through 'peer review and learning'. A common set of policy objectives, indicators, and mechanisms is, of course, far from reality in terms of policy choices (see Lendvai, 2015), although they tend, in this case, to reinforce a kind of 'disciplinary neoliberalism' (Gill, 2001), foregrounding employment and employability, in the context of economic growth, as the key to social inclusion (O'Connor, 2005). At the same time, there has been a growing trend across the EU and beyond to apply a range of remedial measures (which read predominantly as disciplinary measures) on or against those who prove hardest to 'reintegrate into the labour market'.

Across the European policy space, and particularly since the first wave of enlargement by a raft of post-socialist countries in 2004, one paradox of EU social policy has been that increased focus on Roma inclusion has coincided with a measurable deterioration in the socioeconomic position of many Roma themselves. Although the precarity of Roma can be traced to the socialist period, and even before, it is the failure of EU initiatives and projects that is most striking. The Decade of Roma Inclusion, beginning in 2005 (see Guy, 2009, p. 37; Brüggemann and Friedman, 2017, pp. 2-3), saw a recalibrating of the transnational policy space with the EU partnering with the World Bank, the United Nations Development Programme (UNDP), and, crucially, the Open Society Foundation. This, and the EU Framework for National Roma Integration Strategies that followed in 2011 (European Commission, 2011), embraced the 'fiction' (Lendvai, 2015) that 'strategic plans' would turn into 'strategic actions' and positive 'measurable results' across a number of priority sectors, notably citizenship, education, employment, healthcare, and housing and were later extended to include gender issues and anti-discrimination/anti-Gypsyism (Marushiakova and Popov, 2015, p. 22).

A depressing picture of 'wasted funds' (Nicolae, 2014) led to a search for responsibility 'from nation state to supranational units and back, from nation state to the civil sector; from the civil sector to the lack of political will of the major political actors' (Marushiakova and Popov, 2015, p. 22). EU Commissioner for Justice and Fundamental Rights Viviane Reding stated in January 2014 that Roma communities needed 'to be willing to integrate and ... to have a normal life' (quoted in ibid.), an explicit reiteration of the moral underclass 
discourse. In addition to Roma as marginalized in and of themselves comes an exoticization of (supposedly homogeneous) Roma 'culture' and 'lifestyle'. As Vermeersch (2012) has suggested, seeing Roma as a European priority actually serves to delink the issue from national and local policies and politics, while at the same time the Roma question comes to be seen as one of the biggest stumbling blocks to EU accession of post-socialist countries portrayed as 'lagging behind' in terms of 'good practice' (Vermeersch, 2002).

Initiatives from the EU, then, tend to either single out Roma at the expense of non-Roma living in similar circumstances, or more generic policies, for instance, on 'social housing', end up specifically targeting Roma. In the end, anti-Roma discourses merge with critiques of the EU as if it privileged Roma in some way, leaving Roma as the convenient scapegoat for 'the overall failures of the transition and of European integration' per se (Marushiakova and Popov, 2015, p. 22). Crucially, Huub van Baar (2015) has turned this on its head, criticizing the dominance of the narrative that policies geared towards the Roma that 'look good on paper' have failed in their implementation. The problem he points to is that the EU is signified in this way as a political body 'with good intentions' at the expense of a structural analysis suggesting that it might in fact be the 'institutional, political, governmental and socioeconomic architectures and infrastructures' (ibid., p. 7) themselves, including those at the European level, that negatively impact on Roma and other groups.

In Serbia, the Roma social inclusion policy framework is in many ways the result of the country's broader post-2000 welfare restructuring and integration into transnational policy processes. This policy framework has been shaped by intensive policy-making activities and the strong presence of international actors within a 'crowded playground' (Arandarenko and Golicin, 2007) of different initiatives and programmes (Jakšić, 2012, p. 46; Đorđević, 2014, p. 46). As a result of the process of accession to the EU and the signing of the Stabilization and Association Agreement in 2008, Serbia started shifting from 'poverty reduction' to the 'social inclusion' paradigm (Cvejić and Vuković, 2010, pp. 136-137). This shift involved substituting the EU concept of 'relative poverty' for the World Bank concept of 'absolute poverty' (Mijatović, 2014, p. 4). However, paradigms of 'poverty reduction' and 'social inclusion' were still regarded as essentially coherent and mutually compatible in terms of their 'multi-dimensional' understanding of vulnerability (Vidojević, 2012, pp. 150-151).

Roma were identified as one of the groups most vulnerable to multiple mechanisms of disadvantage, and they were the only group defined in ethnic terms (other groups included people with disabilities, women, the elderly, refugees, and the rural population). The notion of Roma vulnerability can be traced in Serbia to the World Bank-led Poverty Reduction Strategy from 2003, with subsequent strategic documents across policy domains restating the same argument (see Government of the Republic of Serbia, 2011, 2013; European Commission, 2016). As a result of the new policy focus, action plans specifically addressing the Roma situation in the domains of education, housing, health, and employment were adopted in 2005 
(Jakšić, 2012, p. 46). In 2009, during Serbia's year-long presidency of the 'Decade of Roma Inclusion', the 'Strategy for the Improvement of the Status of Roma' was adopted, identifying several areas of intervention, including housing, education, employment, and health. Such intensive, almost hyperactive, policy-making was followed by establishing new institutional structures, including a Roma Council and a Roma Co-ordination Body within the Ministry for Public Administration, supervising working groups in nine ministries who were in charge of the implementation of different segments of the strategy (Bašić, 2011, p. 7). At the local level, new arrangements included the employment of Roma coordinators within local government and health mediators and pedagogical assistants in schools (ibid.). Within policy and Roma-expert circles, the implementation of the strategy was assessed as suffering from poor management and coordination and as inadequate for removing obstacles to Roma inclusion (Ombudsman - Republic of Serbia, 2013; see Jakšić, 2012, p. 47; Đorđević, 2014, pp. 45-52).

Serbian policy-making reflects broader post-transition policy processes that build on the idea that Roma constitute both an unequal group that is not integrated into the broader society and a distinct group, that is, an 'actual group of real people that can be accurately counted and characterised' (Surdu and Kovats, 2015, p. 7; see Popova, 2015, pp. 4, 7). Assumptions about systems of ethnic classification have long been criticized. Simpson and Akinwale (2007) have explored problems in measuring ethnic belonging, including questions of unreliability, changes in categories, and conscious changes of affiliation, thus challenging the presumption that ethnicity is a stable characteristic throughout an individual's life. In the Eastern European context, Ladanyi and Szelenyi (2001) have shown how systems classifying Roma populations, as well as those classifying ethnic boundaries, are alterable and flexible. Thus, rather than determining one 'correct' and 'accurate' ethnic classification system, we should address the processes through which these systems are constructed. However, 'ethnically essentialist' assumptions still govern policy actions globally (Acton et al., 2016, p. 4) and inform ethnicized demographics, policies, and statistics in Serbia.

The assumption that Roma people exist objectively and essentially is taken for granted in debates concerning the number of Roma living in Serbia. It is commonly said in policy discourse that the available data are inconsistent and inaccurate and that there are actually more Roma people than the official census data show (Cvejić, 2014, p. 103; Đorđević, 2014, p. 46; Macura, 2014, p. 57; Government of the Republic of Serbia 2016, p. 17), but this remains within an essentialist frame that assumes that the true number can be known and is meaningful. Official statistics focus on 'declared' ethnicity without 'exploring real [sic] ethnic origin' (Radovanović and Knežević, 2014, p. 8). Furthermore, policy actions appear to be based on the understanding that Roma constitute an 'ethnoclass', that is, an ethnic group whose poverty is inherently different from all other groups. According to Goran Bašić, head of the expert group for the Strategy of Social Inclusion of Roma 2016-2025, poverty among Roma is transgenerational, structural, 'static', and long-term and has led to lifestyles that are 
significantly different from those of the majority population, thus necessitating affirmative action and special measures (Bašić, 2014, pp. 9-12; see Đorđević, 2014). Hence, policy intervention in Serbia, not unlike within the EU itself, largely builds on a notion of Roma people as a stable group that can be enumerated and whose characteristics can be determined in a reliable way, conceived as both ethnically distinct and as socially marginalized (Surdu and Kovats 2015: 14).

Studies have, indeed, shown a consistent gap between the socioeconomic position of the general population in Serbia and the position of Roma, indicating multiple deprivations (see Government of the Republic of Serbia, 2016). Some 15 per cent of registered Roma, around 22,000, have the status of being internally displaced persons (IDPs) (Allen, 2016, p. 13). IDP Roma from Kosovo tend to be the 'poorest of the poor', and their disadvantage is compounded by a lack of access to personal documents and hence a lack of access to even the most basic services (Praxis, 2014). EU Progress Reports have consistently noted the gap between the stated intentions of Roma inclusion policies and the realities in practice. While the existing legal and policy framework is seen as 'adequate', implementation is said to lag behind, with negative trends appearing after regulations have been adopted (see Government of the Republic of Serbia, 2016, pp. 2, 18, 29, 30; Negotiation group for Chapter 23 - Republic of Serbia, 2016, p. 205).

\section{Theory and method}

Theoretically, this chapter draws from strands within critical policy studies, the anthropology of policy and development, and relational understandings of power developed within neo-Gramscian, Foucauldian, and Marxist analysis. Work within a broad anthropology of policy tradition (see Shore and Wright, 1997) is critical of the notion of policy as a bounded entity, treating it instead as a complex, messy, and non-linear process. This rejects the idea of policy as a rational, linear system moving from the identification of an 'actually existing' problem in the real world, through the formulation of a solution, and on to implementation, evaluation, and lesson-learning for the next policy cycle. It also understands policy fields as saturated with power relations and ideologies. In his critical ethnography of development interventions, David Mosse sees policy models as scripts through which 'chaotic practices are stabilised, made coherent and validated', and thus 'the gap between policy and practice is constantly negotiated away' (Mosse, 2005, p. 17). Mosse's work points not to the gap between policy 'intent' and 'on the ground' realities, but rather to the ways in which representations of practice, almost inevitably seen as 'successful', actually sustain policy frameworks that are, for all intents and purposes, irrelevant to that practice.

There seems to be an inevitable contradiction between the neutrality of policy language and the inherently political character of its effects, with the neutral language of policy documents contrasting sharply with policy's inherently ideological character, entangled in asymmetrical power relations of various kinds. This is never complete, however, as Stuart Hall reminds us, and instead of looking 
for 'already unified collective political identities, already constituted forms of struggle' (Hall, 1991, p. 169), we need to view the effects of policy as contingent upon their dialectical relations to power and politics. A central theoretical starting point for this chapter, then, is that policy shapes, rather than determines, the field of relations and practices in a given spatial-temporal conjuncture.

Being attentive to both structural inequalities and possibilities of instability is a core premise of Making Policy Move (Clarke et al., 2015b), a recent text that explores the movement of policy through the lens of translation and assemblage. The book is sensitive to the 'double movement' of policy translation - as an act of oppression, almost of treason in Law's terms (Law, 2003), while also always being multiple and contradictory, containing the possibility of instability, creativity, and difference (Clarke et al., 2015a, pp. 35-49). In this approach, policies are not bounded entities that are merely 'transplanted' or 'transferred' from one context to another, but rather are always 'translated', transforming meanings, relationships, and 'orderings of power, knowledge and position' (Clarke et al., 2015a, p. 49) in the process. A translation lens enables exploration of contestations and struggles over policy meanings, practices, and outcomes, with policies conceived of as assemblages of imaginaries, elements, and articulations bounded by radically unfinished power relations. In broad terms, an assemblage is the 'product of multiple determinations that are not reducible to a single logic' (Collier and Ong, 2005, p. 12; see also Marcus and Saka, 2006).

The empirical value of the theoretical lens of translation is most clearly summed up by Catherine Kingfisher, whose ethnographic analysis addressed the many unpredictabilities in the way New Zealand's welfare policy precepts were taken up in the province of Alberta (Kingfisher, 2013). However, she also identified convergences in this policy transfer, for example in the adoption of neoliberal policy frameworks by welfare providers, community service providers, and poor single mothers, thus emphasizing active society models of the person and of welfare provision and placing emphasis on independence and self-direction (ibid., p. 185). This led her to warn against 'fetishizing difference and change' (ibid., p. 191). While divergence might be at work:

... this does not mean that translation is always about transformation and rejection; nor does it mean that power is unable to operate effectively even as it changes hands. Alterations do not necessarily prevent dominant meanings from getting through, and even ideas that are appropriated and redeployed in particular contexts in relation to specific agendas that are markedly different from those of policy elites can carry some of their original force.

(Ibid., p. 184)

Kingfisher's study exemplifies how attentiveness to heterogeneity and divergence within the translation framework does not automatically exclude the view that there are larger forces at work that reproduce hierarchical relations. On the contrary, it renders them more visible. 
This chapter utilizes a broad ethnographic methodology producing 'thick descriptions' based on direct and sustained contacts with actors, including access to 'behind-the-scenes' struggles (Mukhtarov and Daniell, 2016). The main empirical evidence derives from seven months of fieldwork in 2016 observing the implementation of an EU-funded IROC project implemented in three municipalities in south-eastern Serbia. This is complemented by material gathered through 'bending and blending' (Lendvai and Stubbs, 2007) research material with information gathered through other roles as policy consultants, advocates, and practitioners, thus allowing for the construction of an 'institutional ethnography' (Smith, 2005) that explores how individual experiences are connected to wider social and institutional orders. Throughout the chapter, the ethnographic story is based on an opening up of the 'black box' of policy intervention through intensive study of an NGO-led project deeply embedded in supposed 'collaboration' with the public sector. This serves as an appropriate 'vantage point' affording access to wider processes, gaining an insider's understanding of 'policy worlds' (Shore and Wright, 2011, p. 15) while remaining conscious of the 'elsewheres' (Stubbs, 2015, p. 92) of policy-making and implementation that ethnographic research does not have access to.

The 'project' arena affords access to spaces where policies of reform are translated and put into practice and where policy models encounter everyday local dynamics (Mosse, 2005, p. 20). Taking 'the project' as an entry point to understanding the social life of Roma inclusion policy allows a meaningful engagement with actors and their active role in reshaping policy forms on the ground. Moreover, the project always covers different sites and levels of policy hierarchy, allowing for the study of the flow of resources and information between them (Sampson, 2002, p. 308). Engagement with projects allows us to 'both dissect and connect' diverse scales of operation and diverse state, state-like, and non-state actors (Wedel et al., 2005, p. 41). The 'NGO-implemented project' epitomizes the instrumental rationality of policy, that is, the idea that implementing models based on clear causal linkages between problems and solutions can bring about predictable social change (Sampson, 2002, pp. 305-306; Mosse, 2005, pp. 36-37). In broader terms, this mirrors a teleological view of the post-socialist transition as a gradual move towards liberal democracy. Hence focusing on the project site enables observation, on a micro-scale, of the entanglement of policy with the grand narrative of postsocialism, but also the way the latter can potentially be disrupted in everyday encounters, clearly illustrating the importance of ethnography's capacity to 'surprise' (Willis and Trondman, 2000).

\section{Case study: the Inclusion of Roma Children (IROC) project}

The IROC project was funded through a grant from the EU that was intended to promote the social inclusion of vulnerable groups, including Roma, through the provision of community-based services. The IROC project answered this call by 
proposing a set of interventions in the area of Roma children's pre-school and elementary school enrolment and attainment, as well as the prevention of early school leaving in three Serbian municipalities, all located in south-eastern Serbia, the least-developed part of the country with the highest percentage of Roma in the population (Radovanović and Knežević, 2014, pp. 35-39). The project was implemented by a partnership among five organizations, including a large international $\mathrm{NGO}$ as the main applicant and project manager, two Belgrade-based NGOs responsible for day-to-day project management, an NGO based in south-eastern Serbia acting as an intermediary between the Belgradebased partners and the Roma communities and 'stakeholders' in the three municipalities, and a college for pre-school educators.

The IROC project began at the time of the adoption of a new strategy addressing Roma inclusion (2016) developed in the scope of Serbia's accession to the EU. The Serbian strategy subscribes to the EU Framework and adds a further area of intervention, namely social protection. Another guiding document for drafting the Strategy was the so-called Action Plan for Chapter 23 adopted as part of Serbia's EU accession negotiations, which outlines the steps that Serbia should take in order to reach EU standards in the functioning of its judicial system and in its respect for fundamental human rights (Negotiation Group for Chapter 23 - Republic of Serbia, 2016). The vulnerability of Roma is understood as requiring comprehensive intervention from many sectors in close collaboration with each other. The lesson from the perceived failure of the previous policy cycle connected to the 2009 Strategy has been to stress the need for more, and better, coordination and greater sustainability. Crucially, the vulnerability to which policy intervention responds is still conceived of in terms of ethnicity, and Roma are seen as a distinct and identifiable group that is unequal to the rest of society. The EU call for proposals that resulted in funding for the IROC project shares these broader policy assumptions and sees Roma as the most vulnerable group in Serbia. Specifically, persisting prejudices and barriers to fulfilling social rights are invoked to explain the need for the special treatment of Roma people in order to increase their life opportunities (Delegation of the European Union to the Republic of Serbia, 2014, p. 7). The IROC project text shares a similar perspective, quoting a range of data to show that Roma children face difficulties and exclusion in the education system.

However, already at the first meetings of the project managers with prospective local associates, it became clear that it would be difficult to maintain the project focus on Roma exclusion for a variety of reasons. To begin with, frontline workers more or less openly questioned the dominant policy discourse and claims that Roma people were underserved and excluded. They offered alternative first-hand accounts about the situation of Roma and the reality of frontline work. One oft-repeated argument was that Roma parents did not value education enough and tended to misuse the welfare system. Their explanations mainly focused on the child allowance, a benefit distributed by the local administration on the condition of regular school attendance, to be verified by a certificate from 
the school at the beginning of the school year stating that the child is enrolled. In all three towns, frontline workers stressed the allegedly common practice of Roma parents of enrolling their children in order to obtain the certificate and thus to be entitled to child allowance, but not ensuring that their children attend school after the enrolment - thus these children are absent while the parents continue receiving the allowance until the beginning of the next school year, when the time comes to renew the benefit. According to the frontline workers, some of the main reasons for Roma children's school absence were parents taking children with them when they travelled to other parts of the country for seasonal agricultural jobs, and the practice of 'selling the bride' (prodaja neveste) by which families arrange marriages for young girls, who as a result stop attending school. However, what was identified as the main reason in all three towns was that families who sought asylum in the EU (mostly Germany) took their children with them. Asylum-seeking in the EU by Serbian citizens is a phenomenon that has emerged with the 'liberalization' of the Schengen visa regime in 2009, a process that has given Serbian citizens the opportunity to travel without visas to most EU countries. For some of the most disadvantaged, the opening of borders was an opportunity to seek asylum in the EU. The EU data aggregated by ethnicity reported that Roma people made up the majority of asylum applicants from Serbia (European Asylum Support Office, 2015, p. 11). The EU tends to treat these asylum applications as 'unfounded', calling on Serbia to reduce such claims through a 'stick and carrot' approach, combining strengthened Roma inclusion programmes and access to rights in Serbia with the tightening of border controls (European Commission, 2014, pp. 52-53, 2015, pp. 60-61, 2016, pp. 68-69). The south-eastern region of Serbia where the IROC project took place is the region with the biggest share of Roma 'returnees', that is, those who have been returned to Serbia from the EU due to their 'unregulated' status (Radovanović and Knežević, 2014, pp. 56, 60). Most importantly for the IROC project team, as long as families were abroad waiting for the asylum decision the child would be absent from school.

Key members of the project team soon concentrated their efforts on how to recalibrate the project to move the focus from Roma per se to under-achieving pupils from disadvantaged or poor families in general. Over time, as the project evolved, the emphasis shifted from Roma as the main beneficiaries to all who were 'at risk' of 'school dropout'. A 'common sense' regarding the project was constructed that emphasized Roma people's ability to find their way through the system, alongside the denial of the existence of exclusionary practices. More practically, there was an emerging concern that if many children were indeed absent during the school year and left without any prior notice this would inevitably hinder those project activities that were based on continual work with the children. The project team members were conscious of the need, as seen in project reports, to demonstrate 'impact' through numbers served directly by the project's activities. A manager in the lead Belgrade organization held a negative view of the project's focus on Roma people right from the very beginning, 
occasionally discussing and testing out her opinions with prospective associates. The fact that she voiced her concerns served to encourage critical reflections about the 'Roma focus' among a larger group of associates and in the project team.

A broader set of what we might term 'instrumentalized' concerns were also highly relevant to the discourses and practices of project associates, and these were shaped by an understanding of how employment opportunities in Serbia are highly dependent on political party affiliation. One respondent, who had joined Serbia's ruling SNS party, clearly stated: 'I joined only for my personal benefit, I am not interested in anything else. Maybe it does not sound very nice, but everyone else would say the same. They have no idea [what the party stands for]' (Morača and Ankica, 2016). Ankica ${ }^{3}$ worked on the IROC project as a supervisor of mentors when a promised temporary public-works position did not materialize. Not untypical of people in similar positions, Ankica had to balance several roles, including those of a lowly positioned (ruling) party member and activist, a precarious public sector employee, and an NGO policy associate. Her positionality with regard to the party was complex because it involved not only a feeling of dependence on the party framework for a precarious job, but also a sense of her own power to make choices within this framework. Her roles and loyalties continued to overlap as the IROC project began, and she actively took the role of mentor leader, supervising a number of volunteers, including her superior in the party, a man she referred to by his surname, Obradović, who used his power over Ankica within the party to try to avoid fulfilling his commitments on the project.

Local hierarchies and practices, therefore, are pivotal to the translation of policy discourses in 'on-the-ground' projects. Through interactions and informal networks and linkages, then, a project designed to support Roma pupils at risk of leaving school early, or not being enrolled at all, tended to be framed in terms of the very same social arrangements that perpetuated relations of marginalization and exclusion. The direct and seemingly unavoidable influence of political party affiliation was never discussed in the grant programme, project design, or project reporting. Aspects of the programme relating to mentoring, in particular, were shaped by the local political economy structured around party affiliation and patronage.

In addition, the project and the aims it promoted took place in the context of uncertainty and precarity in employment and, more broadly, cuts in some spending on public services as part of broader austerity policies (cf. Ombudsman Republic of Serbia, 2016, pp. 12, 25). Ankica was not alone among the project staff in her dependence on such projects alongside dependence on the dominant political party machine for access to even short-term employment in the public sector. Hence, much like social inclusion policy intervention, the on-the-ground implementation of internationally led job flexibilization was inseparable from practices that were seen as harmful by the very same system of internationally sponsored reforms. Taking this point further, the policy and NGO complex could be viewed as resulting in mutually interlocking power relations. When asked 
about her perception of NGOs, Ankica recalled what she 'heard' other people saying, that the NGOs 'took all the money' (Morača and Ankica, 2016). She explained that this meant that, in the popular perception, NGOs were taking money from the EU while finding volunteers to work for free and keeping the money for themselves. Thus, not only was the policy and NGO complex not understood as external or opposed to asymmetrical power relations shaped by 'informal' practices, but, on the contrary, it was viewed as interwoven with them. However, this interweaving of the two was taking place at higher levels that are not accessible to actors who are tied to the local context. While the allocation of resources through the Party framework might be met with accusations, it was nonetheless embedded in the everyday and in proximity with actors' social networks. On the other hand, NGOs conducting policy interventions seem to be perceived as if being in possession of project technologies and budgets that are out of reach of actors whose role had been constructed as 'local' associates. Thus, Ankica did not see her work for the ruling party and her work for the social inclusion project as mutually exclusive. EU-led policy and NGO intervention were not viewed as being situated on higher moral ground. Rather, both NGO projects and political party affiliation were part of the framework in which she sought to make her way in the future.

There were always fissures in the dominant interpretation of the policy narrative. On the one hand, the project followed the official policy rhetoric of exclusion defined in ethnic terms, and on the other, prospective local associates denied that Roma were powerless and underserved. One of the most contentious claims came from the Director of the Centre for Social Work (CSW) in Banjski Grad, who viewed Roma as abusing and generally profiting from the system of social benefits. What she referred to was the fact that childcare allowance often overlapped in practice with social assistance allowance, which was distributed by CSWs, as well as with additional provisions by the municipality that could include free textbooks, school meals, transportation, and so on, where Roma tended to make up the majority of beneficiaries. The Director speculated that when all these benefits were combined, the situation of Roma was not so bad at all. She contrasted this with low incomes generally in the country, and especially with the income of those working on administering benefits.

This narrative did not go unchallenged, particularly by Dragan, an influential Roma leader in Novograd who, when asked to open a community consultation meeting, repeated, with a degree of authority deriving from his own positionality, the dominant policy and programme narrative, framing Roma drop-out as a result of the interaction between three factors - Roma parents' poor material position, discrimination in schools, and spatial segregation of Roma settlements. During questions, two female school directors openly challenged Dragan's arguments. They accused him of talking vaguely and asked him to name specifically which Roma children, in what school, and when, were discriminated against. The short but heated debate was marked by Dragan's attempts to demonstrate discriminatory practices and frontline workers' attempts to negate them by 
arguing that the practices he mentioned were not a result of ethnic prejudices. He asked if Roma children were ever placed in the front rows, or were they 'destined' to sit in the back, referring to an unwritten rule in schools that the best students sit in the front. A worker from the local employment service reacted by saying that his child, although from the 'majority population', always sat in back rows simply because he was not good at school. The underlying issue in these contestations was the comparison between mass impoverishment, which seemed to receive no attention, and affirmative action only for some according to an 'ethnic principle'. The phrase 'majority population', a common trope in policy discourse, became an object of mockery of prospective IROC associates, and it was seen to be a part of a 'politically correct' language used to avoid the negative connotations associated with the word 'Serb' or 'Serbian', who make up the majority of the population in ethnicized terms.

The vignette from Banjski Grad illustrates a fissure in the interpretation of the Roma inclusion narrative that was often visible in the scope of the IROC project and that seemed to correspond to a public sector/NGO sector divide. It appeared that NGO actors mainly reinforced the official narrative, while those employed in public institutions contested it. At times this discourse invoked the 'punitive undercurrent' of what Hyatt refers to as a 'law-and-order-state' (Hyatt, 2011, p. 119). When frontline workers in Serbia talked about Roma misusing the system of welfare by, for example, taking the childcare allowance but not sending their children to school, they had punitive overtones. Drawing from a 'culturalist' paradigm that drives much of the policy reform discourse in Serbia, their contestation could be explained away as expressing the constructed negative traits of public sector employees, that is, of their being obsolete, outmoded, and over-bureaucratized (cf. Stubbs and Maglajlić, 2012, p. 1180; Vetta, 2012, pp. 183-185). These broader claims are easily translated across the policy world. For example, the EU call for proposals, from which the IROC project was funded, identified the 'immaturity' of social work in Serbia (Delegation of the European Union to the Republic of Serbia, 2014, p. 6) as one of the factors behind the inadequate development of community-based social services in Serbia, notwithstanding social work's 50 or more years of continuous existence in Serbia and the rest of the region (Stubbs and Maglajlić, 2012).

In addition to the NGO sector/public sector divide, the contestation that took place in Novograd indicates a power asymmetry shaped around the national/ local axis. Specifically, both Dragan and the frontline workers were public sector employees. However, the decisive difference between them was that the latter belonged to local institutions, while he was positioned at the national level in proximity to policy-making centres. What is more, the position that they represented and defended was purporting to be authentically 'local', that is, telling 'how things really are on the ground'. Dragan, on the other hand, acted as the spokesperson of the official policy narrative. Viewed in this light, the contestation of the Roma inclusion discourse that came from local public sector employees not only arose from their belonging to the public sector, but also from 
their positionality on the national/local power axis. While the social inclusion policy narrative remains silent about the symbolic and material plight of local frontline workers, the workers use everyday policy encounters as an occasion to make visible what they, as members of the 'majority', see as the grim present (see Kalb, 2009). Thus, their contestation and resentment towards policy discourse, rather than about some kind of intrinsic public sector employee cultural trait, is about re-negotiating their status and perceived power asymmetries.

In many ways, the policy precepts about Roma inclusion proved difficult to retain within the everyday life of the project's implementation. The project narrative and actions were rearticulated in the face of practical concerns and in order to accommodate local practices and hierarchies that were often shaped by partisan loyalties. Furthermore, policy encounters were underwritten by power asymmetries shaped around $\mathrm{NGO}$ /public sector and local/national dichotomies, resulting in local frontline workers' contestation of policy discourse and attempts to reclaim their status. Knowledge hierarchies and resistance to these led, in a sense, to two fissures of translation - between the 'core' EU and the 'peripheral' Serbia as a potential Member State and within Serbia itself between 'national' and 'local' claims.

\section{Conclusions}

Through a critical examination of Roma social inclusion policy implementation in contemporary Serbia, this chapter has shown how policy is reinterpreted as it 'cascades' through project interventions in different locales. Rather than passive acceptance of policy advice coming from the centre, actors contest and dramatically alter aspects of the policy, including the very concepts of Roma exclusion, disadvantage, and discrimination that appear to be central to the policy frame. Policies from different domains combine in often unexpected ways, not least because policies for the 'inclusion of marginalized groups' are overdetermined by the austerity measures introduced in the social protection and education sectors in recent years.

In questioning the usefulness of formalistic accounts focused on analysing policies and their 'effects' as if they were clearly defined, static, and measurable entities, we hope to have provided new insights into the 'black box' of policy implementation by contextualizing these with reference to other policy domains, to neoliberal restructurings, and to the political economy of diverse locales. Without diminishing the real problems of the multiple deprivations of Roma, there might be a need to reconsider the so-called ethnicized perspective (Surdu and Kovats, 2015, p. 8) from which this discourse usually frames social disadvantage. Constructing social disadvantage primarily in ethnic terms might have counter effects on the ground, insofar as members of the 'majority' feel that their own impoverishment is unacknowledged. The 'identitarian' register, disconnected from practices of racism, as a dominant explanatory tool in postsocialist contexts tends to downplay the intersectionality of symbolic and material dispossession in 'transition' contexts (see Kalb, 2009; Jansen, 2015, pp. 11-14; Bilić and Kajinić, 2016). 
A mainstream EU-led social inclusion policy framework when applied to Roma tends to obfuscate the structural causes of Roma deprivation and thus contributes further to their 'displacement' from the policy agenda. At the same time, this framework is never uniformly transposed in a linear way to the 'local' level. Rather, it is selectively altered so as to respond to pragmatic and ideological concerns, institutional arrangements, and instrumentalist opportunities that are shaped, overall, by public sector retrenchment and the practice of austerity. This calls for a view of policy adaptation as involving complex interplay across policy domains, which can accommodate mutually contradictory developments. Social inclusion policy goals can thus be understood as framed by the context of ever more pressing calls for austerity (cf. Stubbs and Lendvai, 2016). Furthermore, although NGOs were not sending ideologically consistent and uniform messages, the effects of the policy-NGO nexus tend to support the restructuring and re-evaluation of the public sector by adding to the assemblage of already volatile policy interventions. Such interventions, insofar as they are both temporarily and geographically limited, have bearings on the exercise of social citizenship rights, introducing a kind of 'welfare parallelism' (Stubbs and Zrinščak, 2015) between state and non-state actors.

A focus on policy translation questions the modernizing paradigm upon which much EU policy discourse relies. The assumption that policies, expertise, and practice can be transferred from policy-making 'centres' and transform realities in 'recipient' countries in a positive sense might need to be challenged. In the 'semi-peripheral' (Blagojević, 2009) context of south-eastern Europe, the assumption rests on a dominant teleology of inevitable movement from the 'backwardness' of socialism to modern liberal democracy and EU accession (see Jović, 2010). Such a critique of linear policy transfer has political implications. Only through greater attention to that which is often missed in formalistic accounts of policy implementation can a potential 'policy otherwise' (Clarke et al., 2015c) be articulated, thus expanding the range of possible meanings of policies, revealing power relations more clearly, and ensuring that voices that are marginalized or distorted can be truly heard.

\section{Notes}

1 All names of research participants, organizations, projects, and locations are anonymized throughout the chapter.

2 Some of the findings discussed in this paper have been published as Morača (2018).

3 Not her real name.

\section{References}

Acton, T., Acton J., Acton, J., and Cemlyn, S. (2016). Why we need to up our numbers game: a non-parametric approach to the methodology and politics of the demography of Roma, Gypsy, Traveller and Other Ethnic Populations. Radical Statistics 114, pp. 3-23. 
Allen, R. (2016). Podrška za IRL u Srbiji - Skraćeni Izveštaj i Preporuke. UNHRC, [online]. Available at: www.unhcr.rs/media/docs/Support_for_IDPs_in_Serbia_ SER_01-IZMENE-01-11-2016.pdf [Accessed 28 October 2018].

Arandarenko, M. and Golicin, P. (2007). Serbia. In: B. Deacon and P. Stubbs, eds., Social policy and international interventions in south east Europe. Cheltenham: Edward Elgar, pp. 167-186.

Bašić, G. (2011). Metodologija istraživanja o primeni državnog programa integracije Roma. Unpublished paper.

Bašić, G. (2014). Siromaštvo Roma i Afirmativne Mere. In: T. Varadi, D.B. Đorđević, and G. Bašić, eds., Prilozi strategiji unapređenja položaja Roma. Belgrade: Serbian Academy of Science and Arts and Ombudsperson Office, pp. 9-25.

Bilić, B. and Kajinić, S., eds. (2016). Intersectionality and LGBT activist politics: multiple others in Croatia and Serbia. London: Palgrave Macmillan.

Blagojević, M. (2009). Knowledge production at the semi-periphery: a gender perspective. Belgrade: Institute for Criminological and Sociological Research.

Brüggemann, C. and Friedman, E. (2017). The decade of Roma inclusion: origins, actors and legacies. European Education 49(1), pp. 1-9.

Clarke, J., Bainton, D., Lendvai, N., and Stubbs, P. (2015a). Translation, assemblage and beyond: towards a conceptual repertoire. In: J. Clarke, D. Bainton, N. Lendvai, and P. Stubbs, eds., Making policy move: towards a politics of translation and assemblage. Bristol: Policy Press, pp. 33-64.

Clarke, J., Bainton, D., Lendvai, N., and Stubbs, P., eds. (2015b) Making policy move: towards a politics of translation and assemblage. Bristol: Policy Press.

Clarke, J., Bainton, D., Lendvai, N., and Stubbs, P. (2015c). 'Policy otherwise': towards an ethics and politics of policy translation. In: J. Clarke, D. Bainton, N. Lendvai, and P. Stubbs, eds., Making policy move: towards a politics of translation and assemblage. Bristol: Policy Press, pp. 187-228.

Collier, S. and Ong, A. (2005). Global assemblages, anthropological problems. In: A. Ong and S. Collier, eds., Global assemblages: technology, politics and ethics as anthropological problems. Oxford: Blackwell, pp. 3-21.

Cvejić, S. (2014). Faces and causes of Roma marginalization: experiences from Serbia. In: J. Szalai and V. Zentai, eds., Faces and causes of Roma marginalization in local contexts. [pdf] Budapest: Center for Policy Studies, Central European University, pp. 97-125. Available at: https://cps.ceu.edu/sites/cps.ceu.edu/files/cpsbook-faces-andcauses-2014.pdf [Accessed 22 October 2017].

Cvejić, S. and Vuković, O. (2010). Socijalna uključenost u Srbiji. In: M. Babović, ed., Izazovi nove socijalne politike. [pdf] Beograd: SeConS - Grupa za razvojnu inicijativu, pp. 135-160. Available at: www.mogucasrbija.rs/files/20120401122802Izazovi\%20 nove\%20socijalne\%20politike.pdf [Accessed 22 October 2017].

Delegation of the European Union to the Republic of Serbia (2014). Guidelines for grant applicants.

Đorđevic, L. (2014). Afirmativne mere za unapređenje položaja Roma u Srbiji. In: T. Varadi, D.B. Đorđević, and G. Bašić, eds., Prilozi strategiji unapređenja položaja Roma. Belgrade: Serbian Academy of Science and Arts and Ombudsperson Office, pp. 27-53.

European Asylum Support Office (2015). Asylum applicants from the Western Balkans: comparative analysis of trends, push-pull factors and responses - update. Available at: www.easo.europa.eu/sites/default/files/public/Asylum-Applicants-from-the-WesternBalkans_Update_r.pdf 
European Commission (2010). Europe 2020: a strategy for smart, sustainable and inclusive growth. Brussels: European Commission.

European Commission (2011). EU framework for national Roma integration strategies up to 2020. Available at: http://ec.europa.eu/justice/policies/discrimination/docs/ com_2011_173_en.pdf

European Commission (2014). Serbia progress report. Available at: https://ec.europa.eu/ neighbourhood-enlargement/sites/near/files/pdf/key_documents/2014/20140108serbia-progress-report_en.pdf

European Commission (2015). Serbia 2015 report. Available at: https://ec.europa.eu/ neighbourhood-enlargement/sites/near/files/pdf/key_documents/2015/20151110_ report_serbia.pdf

European Commission (2016). Serbia 2016 report. Available at: https:/ec.europa.eu/ neighbourhood-enlargement/sites/near/files/pdf/key_documents/2016/20161109_ report_serbia.pdf

Gill, S. (2001). Constitutionalising capital: EMU and disciplinary neoliberalism. In: A. Bieler and A. Morton, eds., Social forces in the making of the New Europe: the restructuring of European social relations in the global political economy. Basingstoke: Palgrave, pp. 47-69.

Government of the Republic of Serbia (2011). National employment strategy for the period 2011-2020. Available at: www.nsz.gov.rs/live/digitalAssets/0/302_nacionalna strategija_zaposljavanja_2011-2020.pdf

Government of the Republic of Serbia (2013). Anti-discrimination strategy for 2013-2018. Available at: https://rm.coe.int/16801e8db9.

Government of the Republic of Serbia (2016). Strategy of social inclusion of Roma for the period from 2016 to 2025. [pdf] Official Gazette of the Republic of Serbia, 05 No. 90-1370/2016-1. Available at: www.ljudskaprava.gov.rs/sites/default/files/dokument file/national_strategy_for_roma_inclusion_2016-2025_0.pdf

Guy, W. (2009). EU initiatives on Roma: limitations and ways forward. In: N. Sigona and N. Trehan, eds., Romani politics in contemporary Europe: poverty, ethnic mobilization, and the neoliberal order. Basingstoke: Palgrave Macmillan, pp. 23-50.

Hall, S. (1991). The hard road to renewal: Thatcherism and the crisis of the Left. London: Verso.

Hyatt, S.B. (2011). What was neoliberalism and what comes next? The transformation of citizenship in the law-and-order state. In: C. Shore, S. Wright, and D. Però, eds., Policy worlds: anthropology and the analysis of contemporary power. New York: Berghahn Books, pp. 105-123.

Jakšić, B. (2012). Politika promene identiteta Roma u Srbiji. In: T. Varadi and G. Bašić, eds., Promene identiteta, kulture $i$ jezika Roma u uslovima planske socijalnoekonomske integracije, Zbornik radova sa naučnog skupa. Beograd, 6-8. decembar 2010. Beograd: Srpska akademija nauka i umetnosti, pp. 39-55.

Jansen, S. (2015). Yearnings in the meantime: 'normal lives' and the state in a Sarajevo apartment complex. New York, Oxford: Berghahn Books.

Jović, D. (2010). Problems of early post-communist transition theory: from transition from to transition to. Politička Misao 47(5), pp. 44-68.

Kalb, D. (2009). Conversations with a Polish populist: tracing hidden histories of globalization, class, and dispossession in postsocialism (and beyond). American Ethnologist 36(2), pp. 207-223.

Kingfisher, C. (2013). A policy travelogue: tracing welfare reform in Aotearoa/New Zealand and Canada. Oxford and New York: Berghahn Books. 
Ladanyi, J. and Szelenyi, I. (2001). The social construction of Roma ethnicity in Bulgaria, Romania and Hungary during market transition. Review of Sociology 7(2), pp. 79-89.

Law, J. (2003). Traduction/Trahison: notes on ANT. [pdf] Centre for Science Studies, Lancaster University. Available at: www.lancaster.ac.uk/fass/resources/sociologyonline-papers/papers/law-traduction-trahison.pdf [Accessed 28 October 2018].

Lendvai, N. (2015). Soft governance, policy fictions and translation zones: European policy spaces and their making. In: J. Clarke, D. Bainton, N. Lendvai, and P. Stubbs, eds., Making policy move: towards a politics of translation and assemblage. Bristol: Policy Press, pp. 131-157.

Lendvai, N. and Stubbs, P. (2007). Policies as translation: situating transnational social policies. In: S.M. Hodgson and Z. Irving, eds., Policy reconsidered: meanings, politics and practices. Bristol: Policy Press, pp. 173-190.

Lenoir, R. (1974). Les exclus: Un français sur dix. Paris: Seuil.

Levitas, R. (1996). The concept of social exclusion and the new 'Durkheimian' hegemony. Critical Social Policy 46, pp. 5-20.

Macura, V. (2014). Nužnost legalizacije neformalnih romskih naselja. In: T. Varadi, D.B. Đorđević, and G. Bašić, eds., Prilozi strategiji unapređenja položaja Roma. Belgrade: Serbian Academy of Science and Arts and Ombudsperson Office, pp. 54-70.

Marcus, E.G. and Saka, E. (2006). Assemblage. Theory, Culture and Society 23(2-3), pp. 101-106.

Marushiakova, E. and Popov, V. (2015). European policies for social inclusion of Roma: Catch 22? Social Inclusion 3(5), pp. 19-31.

Mijatović, B. (2014). Poverty in Serbia 2011, 2012 and 2013. [pdf] Belgrade: Social Inclusion and Poverty Reduction Unit, Government of the Republic of Serbia. Available at: www.clds.rs/newsite/Poverty\%20in\%20Serbia\%202011,\%202012\%20and\%20 2013.pdf [Accessed 31 October 2017].

Morača, T. (2018). The contested journey of social inclusion policy in Serbia: an anthropological perspective. In: G. Motta, ed., Dynamics and policies of prejudice. Newcastle upon Tyne: Cambridge Scholars Publishing, pp. 411-426.

Morača, T. and Ankica (2016). Interview.

Mosse, D. (2005). Cultivating development. an ethnography of aid policy and practice. London: Pluto Press.

Mukhtarov, F. and Daniell, K.A. (2016). Transfer, diffusion, adaptation and translation of water policy models. In: K. Conca and E. Weinthal, eds., The Oxford handbook of water politics and policy. Oxford Handbooks Online.

Negotiation Group for Chapter 23 - Republic of Serbia (2016). Action plan for chapter 23. Available online at: www.mpravde.gov.rs/files/Action\%20plan\%20Ch\%2023.pdf

Nicolae, V. (2014). Between a rock and a hard place - the new Commission and the social inclusion of Roma. [Blog] Valeriu Nicolae. Available at: https://valeriucnicolae. wordpress.com/2014/09/24/ [Accessed 26 October 2018].

O'Connor, J. (2005). Policy coordination, social indicators and the social-policy agenda in the European Union. Journal of European Social Policy 15(4), pp. 345-361.

Ombudsman - Republic of Serbia (2013). Report on the implementation of the strategy for the improvement of status of the Roma in the Republic of Serbia (Izveštaj o sprovođenju Strategije za unapređenje položaja Roma sa preporukama). Available at: www.ombudsman.rs/attachments/3115_IZVESTAJ\%20ZG\%20O\%20SPROVODJENJU\%20STRATEGIJE.pdf [Accessed 31 October 2017]. 
Ombudsman - Republic of Serbia. (2016) Regular annual report of the protector of citizens for 2015. Available at: www.ombudsman.org.rs/attachments/article/132/ Annual\%20Report\%202015.pdf.

Popova, Z. (2015). 'Roma' policy making: key challenges and possible solutions. [pdf] European Centre for Minority Issues. Available at: www.files.ethz.ch/isn/187850/ Brief_34.pdf [Accessed 26 October 2017].

Praxis (2014). Položaj Interno Raseljenih Lica - Kratka Analiza Preostalih Izazova. Available at: www.praxis.org.rs/images/praxis_downloads/Polozaj_interno_raseljenih_ lica_-_kratka_analiza_preostalih_izazova.pdf

Radovanović, S. and Knežević, A. (2014). Romi u Srbiji: Popis stanovništva, domaćinstava i stanova 2011. [pdf] Beograd: Republički zavod za statistiku Srbije. Available at: http://pod2.stat.gov.rs/ObjavljenePublikacije/Popis2011/Romi.pdf [Accessed 26 October 2017].

Salais, R. (2003). Social exclusion and capability: marginalisation and social exclusion. In: International research conference marginalisation and social exclusion. [online] Alesund (Norway). Available at: https:/halshs.archives-ouvertes.fr/file/index/ docid/430491/filename/Social_Exclusion_and_Capability_Volda_lecture_may_2003. pdf [Accessed 26 October 2018].

Sampson, S. (2002). Beyond transition: rethinking elite configurations in the Balkans. In: C.M. Hann, ed., Postsocialism: ideals, ideologies and practices in Eurasia. London: Routledge, pp. 297-316.

Shore, C. and Wright, S., eds. (1997). Anthropology of policy: critical perspectives on governance and power. London: Routledge.

Shore, C. and Wright, S. (2011). Conceptualising policy: technologies of governance and the politics of visibility. In: C. Shore, S. Wright, and D. Però, eds., Policy worlds: anthropology and the analysis of contemporary power. New York: Berghahn Books, pp. $1-25$.

Simpson, L. and Akinwale, B. (2007). Quantifying stability and change in ethnic group. Journal of Official Statistics 23(2), pp. 185-208.

Smith, D.E. (2005). Institutional ethnography: a sociology for people. Lanham: AltaMira Press.

Stubbs, P. (2015). Performing reform in South East Europe: consultancy, translation and flexible agency. In: J. Clarke, D. Bainton, N. Lendvai, and P. Stubbs, eds., Making policy move: towards a politics of translation and assemblage. Bristol: Policy Press, pp. 65-94.

Stubbs, P. and Lendvai, N. (2016). Re-assembling and disciplining social Europe: turbulent moments and fragile f(r)ictions. In: Z. Krajina and N. Blanuša, eds., EU, Europe Unfinished: mediating Europe and the Balkans in a time of crisis. London: Rowman \& Littlefield, pp. 31-55.

Stubbs, P. and Maglajlić, R.A. (2012). Negotiating the transnational politics of social work in post-conflict and transition contexts: reflections from South-East Europe. British Journal of Social Work 42(6), pp. 1174-1191.

Stubbs, P. and Zrinščak, S. (2015). Citizenship and social welfare in Croatia: clientelism and the limits of 'Europeanisation'. European Politics and Society 16(3), pp. 395-410.

Surdu, M. and Kovats, M. (2015). Roma identity as an expert-political construction. Social Inclusion 3(5), pp. 5-18.

van Baar, H. (2015). Governing the Roma, bordering Europe: europeanization, securitization and differential inclusion. Keynote lecture, Duke University. Available at: www. 
academia.edu/18165726/Governing_the_Roma_Bordering_Europe_Europeanization Securitization_and_Differential_Inclusion_2015 [Accessed 26 October 2018].

Vermeersch, P. (2002). Ethnic mobilization and the political conditionality of European Union accession: the case of the Roma in Slovakia. Journal of Ethnic and Migration Studies 28(1), pp. 83-101.

Vermeersch, P. (2012). Reframing the Roma: EU initiatives and the politics of reinterpretation. Ethnic and Migration Studies 38(8), pp. 1195-1212.

Vetta, T. (2012). NGOs and the state: clash or slass? Circulating elites of 'good Governance' in Serbia. In: B. Petrić, ed., Democracy at large: NGOs, political foundations, think tanks and international organizations. New York: Palgrave Macmillan, pp. 169-190.

Vidojević, J. (2012). Konceptualizovanje socijalne uključenosti u Srbiji - Karakteristike i osnovni aspekti socijalne isključenosti. In: Z. Stojiljković, ed., Lavirinti tranzicije. Beograd: Friedrich Ebert Stiftung, Centar za demokratiju Fakultet političkih nauka Beograd, pp. 147-164.

Wedel, R.J., Shore, C., Feldman, G., and Lathrop, S. (2005). Toward an anthropology of public policy. The ANNALS of the American Academy of Political and Social Science 600(1), pp. 30-51.

Willis, P. and Trondman, M. (2000). Manifesto for ethnography. Ethnography 1(1), pp. 5-16. 


\title{
Ethnicizing poverty, implementation of structural funds in Slovakia
}

\author{
Joanna Kostka
}

\section{Introduction}

It is now widely accepted that the growth in prosperity for many citizens living in former communist countries has not reached everyone and that the gap between those who have gained and those who have not has widened. Despite $€ 351.8 \mathrm{bn}$ in investments under the cohesion policy for smart, sustainable, and inclusive growth, inequalities in the European Union (EU) stand at an unprecedented level with around 120 million people experiencing poverty. ${ }^{1}$ Among them stands one of the European minorities, Roma, who still belong to the poorest and most excluded populations in Europe and who are continually subjected to pernicious patterns of exploitation, exclusion, and stigma (Sigona and Vermeersch, 2012). The EU institutions have long emphasized the need to ensure that Roma people are treated equally with respect to their fundamental rights, as enshrined in the Charter of Fundamental Rights of the EU. However, the EU's political and financial commitments have not generated perceivable change. According to the latest survey by the European Union Agency for Fundamental Rights (FRA) (2018) that collected information on 34,000 persons living in Roma households in nine EU member states, 80 per cent of the respondents live below their country's at-risk-of-poverty threshold, and every third Roma child lives in a household where someone went to bed hungry at least once in the previous month. Only 30 per cent of the Roma surveyed were in paid work compared with the average EU employment rate for 2015 of 70 per cent. At the same time, 41 per cent of Roma feel they have been discriminated against over the past five years in everyday situations such as looking for work, at work, housing, health, and education. Essentially, the situation of Roma communities appears as precarious today as it has ever been with the ongoing economic crisis and the rise of the far right contributing to this predicament. In essence, the transition from totalitarianism to democracy has failed to benefit long-oppressed communities.

The interest in the Roma people as a 'policy problem' acquired a strategic connotation in 2004 when the Central and Eastern European (CEE) countries joined the EU. ${ }^{2}$ The mass impoverishment and disenfranchisement of Roma people in the post-communist countries not only posed dramatic implications for 
economic development in the region, but also clashed with wider EU values of equal opportunities and non-discrimination. ${ }^{3}$ In response, the European Commission (EC) has advised the new member states to make full use of the EU's instruments, particularly the system of financial transfers known as Structural Funds (SFs) (European Commission, 2004, p. 42). Consequently, the Regulation on the European Social Fund (ESF) for the 2007-2013 and 2014-2020 programming periods introduced an investment priority that specifically refers to 'integration of marginalised communities such as the Roma' (European Parliament, 2015, p. 27). In the 2007-2013 funding period, €26.5 billion was made available for social inclusion projects as a whole, and the new financial period 2014-2020 saw $€ 80$ billion allocated to investment in human capital, employment, and social inclusion (COM/2014/473 final). Presently, the member states are expected to earmark at least 20 per cent of the ESF (around $€ 16$ billion) for social inclusion programmes (up from the previous average of 15 per cent, which was not compulsory) (Andor, 2018).

Paradoxically, the hefty investments have corresponded with the deteriorating socioeconomic conditions of Roma communities and the escalation of racist violence. Not surprisingly, the EC - a self-proclaimed champion of Roma rights - has been confronted with a chorus of critical voices calling SF investments a clear policy failure in need of critical examination and immediate action by the national and regional polities. EU funding has arguably generated some success stories, and the (mis)use of funding by member states has been far from uniform (Roma Civil Monitor, 2018; Kostka, 2019). However, in the CEE region, the financing of Roma inclusion initiatives is riddled with alarming deficiencies (Roma Civil Monitor, 2018). In particular, in countries and regions with a larger Roma population the absorption rates remain critically low, as is the accessibility of the funds by the most impoverished communities (Hurrle et al., 2012; Kóczé et al., 2014). This is despite the EU's ongoing commitments to streamline the targeting of the ESF and to impose stringent rules on conditionality and sanctions for the allocation of funds.

This chapter explores why the use of the ESF for the creation of inclusion projects for the Roma population fails to deliver positive outputs, and it proceeds in three parts. First, building on a constructivist approach to policy-making it challenges the notion that the implementation of SFs follows a rational comprehensive model, whereby policy-makers define their goals clearly and canvass many (ideally all) alternatives that might achieve these goals. It argues that cohesion policy has built into it a particular representation of what the problem is, and this structures the implementation process and its outputs. The second part examines the way the EU has constructed social exclusion as a 'problem' inside its cohesion funding schemes. The third section presents empirical evidence from Slovakia, a country with a particularly tenuous record, building on data collected via content analysis of policy documents and 30 semi-structured interviews conducted with senior policy-makers, project managers, and Roma advocates involved in the formulation and implementation of SF programming.

In public policy research, content analysis is a method used for deconstruct- 
ing policy texts (legislation, procedures, evaluations, etc.) according to preestablished analytical categories (based on theoretical assumptions) and a set of standardized questions. The content of strategic documents was analysed in two dimensions: (1) instrumentality - identifying objectives, priorities, tools, and regulatory provisions; and (2) the discursive elements - policy framing, i.e. an 'organizing principle that transforms fragmentary or incidental information into a structured and meaningful problem in which a solution is implicitly or explicitly included' (Verloo, 2005). Subsequently, the content analysis was triangulated with interview-based investigations to capture how policy texts were realized (where, by whom, and to what ends). The use of interviews as a data collection method is based on the assumption that the participants' perspectives are meaningful, knowable, and can be made explicit and that their perspectives affect the success of the project. As such, they are well suited not only for gathering 'descriptive' data, but also for exploring attitudes, values, beliefs, and motives (Richardson, 1965; Smith, 1975). The questions used in the semistructured interviews were developed using the suggestions of Patton (1990) and the pre-assessment of SF programmes using secondary data. The questions sought to generate factual knowledge about existing administrative procedures, departmental responsibilities, and institutional interactions. Efforts were also made to inquire about stakeholders' perceptions about the effectiveness and legitimacy of SF approaches. The interviewees were also asked to describe their roles and experiences in the specific projects and when possible to provide expert comments about the general workings of SF programming and other domestic social inclusion strategies.

The presented evidence suggests that the reluctance of key policy-makers to consider the role of structural inequalities when formulating action plans legitimizes views that the problem is caused by the inability (or unwillingness) of Roma people to function inside the mainstream society. This chapter concludes that the ethnicization of Roma poverty means that funding is channelled into short-sighted measures aimed at changing the behaviour of a 'problematic' population under the auspices of a 'civilizing mission'.

\section{Constructivist approach to policy implementation}

The allocation of EU cohesion policy resources involves complex procedures of regional development planning, programme management, and project delivery, with substantial bodies potentially having different roles and responsibilities in the decisions at each stage. This multifaceted institutional landscape is structured by a range of principles (e.g. partnership, additionality) and political interests (Bachtler and McMaster, 2008). The sheer complexity generates conflicting and incommunicable views on cohesion policy, and this is fuelled by the scarcity of solid evidence on results, by the inadequacy of the debate on the policy conceptual framework, and ultimately by ambiguities in the policy objectives (Barca, 2009). Roma issues continue to lag in the backwaters of wider cohesion scholar- 
ship, which results in a superficial analysis of the politics of integration. The dominant narratives focus on high-level negotiations and institutional restructuring and fail to account for the more nuanced dynamics related to policy design and minority representation. Much of the language of European cohesion policy eschews the idea of trade-offs between efficiency and equity, suggesting that it is possible to maximize overall growth while also achieving continuous convergence in outcomes and productivity across Europe's regions. Yet, even though there seems to be an agreement that cohesion policy has at least partly altered the pathways of development, its effectiveness in reducing social exclusion continues to be heavily disputed (Bachtler and McMaster, 2008; Popa, 2012). The implicit assumption that decision-makers come up with the best solution given cultural, political, and economic constraints obscures conflicting values and ideological convictions that orient the articulation of public problems in action plans. The analysis regularly pins the ineffective utilization of SFs onto the implementers under the mistaken presumption that policy success is a product of administrative capacities in the field rather than the politicized design of financial incentives.

The constructivist approach to implementation provides a more critical stance, challenging the false assumption that policies are passed down to implementation staff with their goals and objectives made clear, their ambiguities eliminated, and their relationship to other policies adequately sorted out. Its focus on the discursive element of policy-making highlights the existence of subjective convictions that inform what needs to be addressed and why. The constructivist approach challenges the 'artificial' separation between policy formulation and policy implementation, and it asserts that the articulation of public problems rarely stems from objectively identified situations or explicit public demands. Instead, the identification process is strongly contingent on perceptions (Kooiman, 2003) or political biases (Edelman, 1985). Goffman (1974) refers to this phenomenon as 'framing', a concept implying that the articulated problems are not simple descriptions of reality but are specific representations that give meaning to reality. Bacchi's (1999, p. 21) 'What's the problem' approach teases out the presupposition in competing interpretations of social conditions arguing that 'every postulated solution has built into it a particular representation of what the problem is, and it is these representations and their implications that need to be discussed'.

For example, in a European context social exclusion has been framed in terms of both structural inequalities and individual (in)adaptability, the latter gaining ground in the progressively neoliberal environment and its entrepreneurial logic (Miller and Rose, 2008; Sigona and Trehan, 2009). The neoliberal focus on cultural (or individual) deficiencies induces victim blaming and generates solutions that not only rebuff growing social insecurity but also relieve the state of responsibilities for upholding the human rights of all its residents. Brown (2006, p. 693) calls this neoliberal political rationality 'a specific form of normative political reason organizing the political sphere, 
governance practices, and citizenship'. It governs not only political interactions, but also the criteria for what is thinkable, sayable, and doable at certain historical moments. Miller and Rose (2008) argue that precisely such neoliberal political rationality has translated into cohesion policy via rules, regulations, target goals, and criteria that are decided by the EC. SF programmes, they continue, 'are not simply a formulation of wishes or intentions [...] but lay claim to a certain knowledge of the sphere or problem to be addressed'. Farole et al. (2011) demonstrate empirically that the faith in the market has de-integrated the social dimension of inequality from broader macro-economic growth objectives. A concern with social inequalities came to be replaced by the exigency of modernization, entrepreneurship, and external problems associated with the relatively poor performance of the EU in the face of an increasingly globalized economy. The cohesion agenda came to be dominated by employability, labour force adaptation, and job creation. Not surprisingly, while SFs have generated some economic growth (Popa, 2012), the social inequalities ranging from gender and racial inequalities to health status have hardly subsided (OECD, 2017).

Today, few existing inquiries problematize the way cohesion stakeholders define exclusion or deconstruct the relationship between 'marketized' framing and an equitable solution to marginalization of certain social groups. The next section of this chapter examines the discursive claims about Roma exclusion within cohesion policy and demonstrates how these claims affect the implementation of SFs.

\section{Roma exclusion as a policy template}

While the concept of Roma exclusion has come to occupy a central position in the discourse on integration, its exact meaning is diluted by fractious positions on the historical and ethnic dimensions of marginalization and oppression (Barany, 2002; Kovats, 2002; Goldberg, 2009; Van Baar, 2011; Vermeersch, 2012; Ram, 2014). Key disagreements revolve around the causes and meanings of the unequal socioeconomic standing of Roma minorities and thus disagreements over desirable solutions (O’Nions, 2007; Sigona and Vermeersch, 2012; Rostas et al., 2015; Law and Kovats, 2018). While debates on the complex situation of Roma communities have generated increasingly polarized responses, in the domain of cohesion policy contestations remain subdued with few scholarly inquiries challenging the official discourse driven by policy experts and EU agencies. The preserved impression in policy literature is that adopted funding objectives reflect the 'real' needs and interests of target groups and communities (under the assumption that these groups provide extensive input during the formulation stage in line with the partnership principle). However, the stark lack of policy research on the causes of the social exclusion of Roma challenges these assertions. In 2016 Henri Grethen, the Member of the European Court of 
Auditors responsible for audit of the use of EU funding for Roma projects in 2007-2013, insisted:

As things stand, we don't really know how well Roma are being integrated because we don't have robust data; we don't even know how many Roma there are. Unless the data problem is resolved, policymaking will soon be hampered all the way to 2020 .

(European Court of Auditors, 2016)

This blunt avowal, echoed by the majority of local Roma stakeholders, demonstrates that the vast majority of inclusion schemes targeted at Roma communities are based on normative perceptions about the Roma population, which unduly simplify the social, economic, political, and institutional complexities of the conditions they face.

Over the last decade, the EU has endorsed a view of Roma exclusion as a phenomenon closely associated with rapid social and economic change in European societies and beyond. This framing has often assumed that Roma people in the CEE region are dislocated from the economy and society following the transition to a market economy because the nature of employment changed, migration increased, and familial and other social bonds loosened (European Commission, 2004). As a template for financial assistance, there have been two 'constants' in the EU's interpretation of Roma exclusion in the CEE region, namely multidimensionality and ethnic specificity. The EC recognized that Roma people face 'limited access to high quality education, difficulties in integration into the labour market, correspondingly low income levels, and poor health' (COM/2010/0133 final). The proliferation of anti-discrimination rhetoric indicated a growing recognition of deep-seated anti-Gypsyism in the region. Simultaneously, the EC emphasized that the Roma are a unique cultural group that faces a set of problems that differ considerably from those faced by the majority population (Kendea et al., 2017). In 2010, the Progress Reports on Economic and Social Cohesion made an explicit reference to Roma and said that they are 'deemed especially susceptible to social exclusion' (COM 2010/0110 final).

While the specificity of Roma exclusion has often been attributed to spatial factors - including residence in disadvantaged and economically lagging regions - cultural practices (including marriage customs, lack of relevant market skills, and low value of education) have appeared to dominate political discourse (European Commission, 2004, 2010, 2014a). In many ways, discussion on the Roma 'quandary' was absorbed into an ancient moral critique of the poor, identified in modern industrial society with chaotic, disorganized lives, the absence of parental ambition for their children, aversion to hard work, and a propensity for criminal activities. In 2014, Viviane Reding, the European Commissioner for Justice and Fundamental Rights, legitimized such a moralist stance by stating that Roma communities need 'to be willing to integrate and to be willing to have a normal way of living'. While the idea of culture as a cause of exclusion has 
been tenacious, it did lend a shimmer of scientific authority to the idea that poverty is transmitted culturally and that economics has little or nothing to do with it. It also fit comfortably with the ongoing neoliberalization of the region a process that has replaced the redistribution of wealth in favour of the poor with market-driven values and the individualization of social problems (Chelcea and Druta, 2016).

The content analysis of strategic cohesion documents from the last two funding periods shows that the deprivation of the vast majority of the Roma people has indeed been ethnicized. On one hand, the funding objectives have essentialized the cultural traits of a highly diverse ethnic group, while on the other hand they have stressed the inability of individuals identifying as Roma to participate in the 'market game'. A European Framework for Social and Territorial Cohesion (COM(2010)758 final) diagnosed Roma poverty in terms of the community's inability to enjoy social rights without help, the inadequacy of its capacity to meet obligations, and its long-term welfare dependency. Disproportional attention was paid to the presumed 'inability [of persons at risk of exclusion] to take part in the "normal" relations and activities at hand to most people within the society, no matter if these belong to the economic, social, cultural or political domain' (European Commission, 2010b, p. 1). Systemic factors (structural racism, lack of multicultural education, austerity, etc.) were overshadowed by concerns about existing 'gaps' between Roma and non-Roma people, conceptualized strictly in terms of access to services (European Commission, 2011, 2016). The explicit assumption was that access to services and employment would help once-marginalized groups to gain necessary skills and knowledge (delivered through various training and mediation measures) (European Commission, 2010b, p. 4). Effectively, terms such as 'citizenship rights', 'equality rights', and 'social solidarity' gave way to 'labour activation', 'training', and 'participation'.

Critical Roma scholars argue that the problematization of Roma exclusion after the fall of state socialism has masked the historical oppression of the Roma population and deep-seated institutional inequalities (Van Baar, 2011; Kóczé and Rővid, 2017; Picker, 2017; Voiculescu, 2017). It is important to stress that the diagnostic section of the cohesion framework made no reference to structural racism or racialization processes. Under the label 'marginalized communities', Roma issues were hardly discussed within a wider landscape of rising levels of social inequality and erosion of workers' rights, civil liberties, and human rights. Instead, Roma communities were presented in isolated terms, as a 'category' of their own, naturalizing the criteria used 'to evaluate Roma's human capital as one of poverty, exclusion, and marginalization' (Magazzini, 2016, p. 58). Such blunt reluctance to recognize the structural dimension and commonality of Roma exclusion has perpetuated (and strengthened) the pervasive trend of seeking the cause of failures and the justification for funds invested in vain in the community itself (Drál, 2008; Marushiakova and Popov, 2015). In technical terms, the ethnicization of exclusion has reinforced the decoupling of integration measures from 
mainstream reforms and development programmes. While calls for mainstreaming of integration policies echo across all strategic documents and have been incorporated into what is now known as the Common Basic Principles on Roma Inclusion, the evidence base accounting for the implementation of these measures is limited (Roma Civil Monitor, 2018). Instead, the cohesion framework has fully embraced the targeted approach to making Roma ethnicity an organizing principle for the EU cohesion policy. Kovats (2012) cautions that the EC's version of targeting acts merely as a tool for inserting the Roma into mainstream society and fails to unleash structural reforms or to address the general decline in the inclusivity of the modern welfare state.

The next section presents the Slovak case demonstrating that the adoption of EU 'frames' on Roma exclusion and endorsement of targeted measures delivered a short-term, depoliticized, technical solution that failed to generate the needed structural reforms and only further ostracized and essentialized Roma communities.

\section{The case of Slovakia}

The situation of the Roma minority represented one of the most serious challenges during the negotiations for the EU membership of Slovakia and other CEE countries. The 2003 Comprehensive Country Monitoring Report for Slovakia stated:

Despite continuous efforts across all sectors, the situation of the Roma minority remains very difficult. The majority of the persons belonging to the Roma community are still exposed to social inequalities, social exclusion and widespread discrimination in education, employment, the criminal justice system and access to public services.

(European Commission, 2003, p. 34)

With the limited possibilities to intervene directly in domestic policies, the EC contended that SFs are a pertinent tool to generate compliance and to place the Roma high on political agenda. The 'carrot' dynamics proved successful, and even though Slovakia and the EC did not agree on any final numbers, it was mutually understood that a significant share of EU financial resources would be used for activities in favour of marginalized Roma communities (Hurrle et al., 2012). The prospect of substantial funding opportunities has prompted consecutive governments to set the path towards Roma integration, at least in major policy documents (Roma Civil Monitor, 2018). However, the implementation of integration strategies has been challenging at best.

Empirical studies and evaluation reports document the sub-optimal utilization of available European funding for the integration of Roma citizens, and Slovakia continues to lag behind other countries in the region in terms of allocation, absorption, and sustainability of individual projects (Open Society Institute, 
2010; European Parliament, 2011; Centre for Strategy and Evaluation Services, 2011b; Hurrle et al., 2012; Roma Civil Monitor,2018; Kostka, 2019). In 2007-2013, Slovakia allocated less than 1 per cent of the total ESF funding towards integration programmes (Centre for Strategy and Evaluation Services, 2011a) and reached only 20 per cent in paid expenditures (COM(2013)210 final; European Commission, 2013). According to the United Nations Development Programme study Uncertain Impact: Have the Roma in Slovakia Benefited from $E S F$ ?, communities at risk of social exclusion were not included in the mainstream measures, and only one fifth of the implemented projects were located in the most segregated and underdeveloped localities (Hurrle et al., 2012). Interviews with the managing authorities confirmed that less than 5 per cent of implemented projects were sustained beyond the period of grant payments, and only a handful were scaled up. The situation has not improved in the 2014-2020 period despite stronger conditionality and monitoring (European Commission, 2016). Excessive delays in contracting funds allocated under the priority of 'integration of marginalized Roma communities' (close to $€ 450$ million) have prevented the effective implementation of both the 'soft' and 'hard' measures, with the absorption rate standing at less than 30 per cent in 2018 (Roma Civil Monitor, 2018). The access to funding for the communities in need remains restricted, and the quality of the implemented projects has faced growing criticism (Jovanovic, 2015).

What is particularly striking in the case of Slovakia is that the failure to implement SFs corresponds with a strong record of compliance with the EU cohesion framework and recommendations. As commented by a senior public servant: 'Slovakia has a lot of work to do in terms of transposition of EU acquis; however, in terms of cohesion policy we have done all that was required and even more. ${ }^{4}$ In fact, Slovakia was the first member state that included a specific horizontal priority, the Marginalized Roma Community, in its SF programming, which required each operational programme (OP) to designate a section describing how general measures will contribute to Roma integration. Slovakia also recognized the multi-dimensionality of Roma exclusion, and adhering to the European recommendations Slovakia adopted an 'integrated approach' combining resources from different OPs for project generation. In line with the partnership principle, Roma representation was engaged under the auspices of the Slovak Government Plenipotentiary for Roma Communities and the Social Development Fund, both of which are agencies responsible for managing projects targeted directly at Roma communities. In the 2014-2020 funding period, the government has further elaborated on its targeted approach by introducing 'Take-Away Package', a programme earmarked for 150 towns and municipalities with the least-developed Roma communities (Operational Programme Human Resources, 2014). The current funding period has also seen a greater allocation to the programme of health mediators (close to $€ 11.3$ million) and 'civil patrols' ( $€ 17$ million) (Roma Civil Monitor, 2018), both of which are strongly advocated by the EC. Overall, leaving the actual impact of these efforts aside, they fully reflect EU recommendations and conditionality. 
A closer look demonstrates that the implementation failure has been strongly contingent on the design of the national cohesion framework, which in many respects mirrors the culturally driven definition of Roma exclusion endorsed by the EC. The strategic documents guiding the allocation of SFs, namely the NSRF and the OPs, have traditionally diagnosed Roma exclusion in a superficial or anecdotal manner that is not substantiated with reliable data. As argued by a member of the Monitoring Committee, '[t]he so-called ex-ante evaluations are simply copied and pasted from the EU templates, not supported by any comprehensive research or even genuine reflection'. While documenting the extreme levels of deprivation across the country, The Atlas of Roma Communities (2013), which is perhaps the only comprehensible study of the socioeconomic situation of Roma people in Slovakia, does not explain the causes of persistent and deep-cutting marginalization nor does it frame the research in terms of citizenship rights or equality. The historical dimension of oppression and marginalization is missing altogether. Perhaps more importantly, funding objectives do not address the unswerving criticisms of the ongoing violation of Roma rights by the Slovak state. For example, despite commitments to channel EU funding to 'improving access to education' (Operational Programme Education of the Slovak Republic, 2007), the infringement proceedings launched in 2015 by the EC against Slovakia for the systemic discrimination and segregation of Roma children in education remain open. Despite documented patterns of segregation and over-representation of Roma children in special schools and classes for children with disabilities, the OP Education has never 'diagnosed' this issue and instead has linked inadequate education attainments of Roma children to a 'low value of education among Roma communities' (ibid., p. 62).

Seemingly oblivious to the existence of oppressive structures, the Slovak cohesion framework has continually stressed that the exclusion of the Roma population is unique in its scope and character. The 2011 Strategy of the Slovak Republic for the Integration of Roma up to 2020 maintained that 'Roma exclusion takes extreme forms that are not to be found in the majority population in marginalized regions' (ibid., p. 4). The strategy has neither elaborated on nor analysed this 'uniqueness' against historic and socioeconomic patterns of inequality. As commented by an NGO worker, '[t]he Roma socio-economic predicament is seen as something natural and at the same time ahistorical; it is never discussed in a wider political context, and it is never related to pervasive racism, structural inequalities, or exploitative economy'. ${ }^{6}$ Indeed, cohesion strategies have replaced structural causes with concerns about dependency on the social system and the disintegration of traditional social institutions. The National Strategic Reference Framework for the 2007-2013 funding period explicitly stated that while some people 'exclude themselves voluntarily from socioeconomic life', others are 'unable, incapable or unwilling to access available rights' (National Strategic Reference Framework, 2007 pp. 24, 56, 158). Similar assertions appear in the OPs, pointing out that the unfavourable position of marginalized citizens stems from a lack of 'basic competences which often led to helplessness and an inability to guide or control the decisions, which have 
implications for day to day life' (Operational Programme Employment and Social Inclusion, 2007, p. 47). The focus on individual capabilities was endorsed by the Slovak Ministry of Labour, Social Affairs and Family:

We cannot ignore the fact that individuals experience exclusion because they do not possess adequate skills to compete in the labour market or access basic services. Lack of education, lack of experience, and yes at times a lack of motivation reinforces intergenerational poverty. Our job is to help these people gain skills and knowledge so they can become active citizens. The SF allows us to build such programmes. ${ }^{7}$

Paradoxically, the individualization of exclusion has corresponded with the essentialist concept of Marginalized Roma Communities (MRCs), which has added a new impetus to long-standing prejudices towards Roma communities as the so-called losers of the transition. As commented by an NGO worker:

The introduction of the term MRC was supposed to secure allocation of funding to the most impoverished communities; instead, the very term is now used by politicians to describe Roma culture as one of worklessness and criminality, a homogeneous culture of poverty that's incompatible with Slovak norms and customs. ${ }^{8}$

The role of Roma culture in perpetuating exclusion has been emphasized in all cohesion strategic documents. While the NSRF stressed that 'different cultural characteristics serve as barriers to meaningful integration' (National Strategic Reference Framework, 2007, pp. 21, 23), the OPs emphasized that 'natural socio-hierarchical rules of social life in Roma communities pose a risk for building up and maintaining communication barriers' (Operational Programme Employment and Social Inclusion, 2007, p. 63). In this manner, SF programming reinforced widely held public perceptions that Roma need to change in order to benefit from 'benevolent' and highly efficient systemic provisions.

The framing of Roma exclusion in terms of culture, (in)adaptability, and distinctive patterns of exclusion has continued in the 2014-2020 funding period. The changes in the programme have meant that the main portion of funds for Roma integration has been earmarked for the OP Human Resources under priority axis 5 'Integration of Marginalized Roma Communities'. ${ }^{9}$ While the current funding strategy recognized the existence of 'systemic' causes of exclusion (i.e. denial of civil, political, and essential human rights), it placed stronger emphasis on individual liability - once again defined in terms of individual failure, low educational attainment, and overall uncertainty and vulnerability. A Roma activist from Kosice insisted:

The Slovak government continues to portray Roma as uneducated, culturally backward, and lazy people, predisposed to criminality and dependent on social benefits. Sure, the funding strategies use more politically correct 
phrases, but the politicians bluntly state that entire communities are lagging behind because of some natural behavioural inclination. ${ }^{10}$

The focus on pathologies has indeed overshadowed concerns about structural inequality. In 2016, Prime Minister Robert Fico and Minister of the Interior Róbert Kaliňák made the announcement to tackle 'Roma criminality' and 'problematic' settlements while at the same time supporting reforms to decrease the child allowance (Roma Civil Monitor, 2018). These dynamics are what Kóczé and Rővid (2017) termed the 'politics of double discourse' where promotion of 'integration' and 'social inclusion' of the Roma is neutralized by anti-Roma racism blatantly supported by mainstream politicians and the public (United Nations, 2016). As commented by a local activist: 'In order to fight exclusion, we first need to fight systemic oppression. The EU wants to implement neat technical training projects in a highly polarised landscape and flourishing of violent and racist sentiments. That simply cannot work.'11

\section{Implementation}

The framing of Roma poverty in terms of a cultural facet driven by individual rejection of common norms, accepted standards, and responsibilities automatically redirected the SF from interventions aimed at deeper institutional change. The notorious neglect of institutionalized discrimination and racism has made many projects of little practical value. As expressed by local Roma community leaders: 'We do not need training or IT equipment; we need far-reaching initiatives like land reforms, de-segregation, and integrated and multicultural education. The SFs do not deal with the entrenched discrimination and subjugation of the Roma people. ${ }^{12}$ The analysis of project reports shows that the majority of implemented initiatives did not internalize anti-discrimination or equal treatment goals. According to the 2011 Country Report, less than 2 per cent of the implemented projects addressed discrimination either directly or indirectly. ${ }^{13}$ The situation remains the same in the current funding period with less than 5 per cent of projects espousing anti-discrimination aims (Kostka, 2019). According to Roma activists, this completely undermines the legitimacy of SF projects:

For a long time, we've been saying that what needs to be targeted are the structures of exclusion and not just the excluded people. This might sound insensitive, but offering training to people who live in segregated communities and face daily discrimination in employment and other areas of life, well, that is just throwing money out the window. SFs should be used to change policies, tackle discrimination, promote equality [...] we don't have projects like that. ${ }^{14}$

The focus on adaptability and the insertion of 'marginalized' individuals into the system resulted in the entrenchment of the targeted regime. However, the design 
of 'targets' simply reinforced the stigmatization of Roma communities. The targeting articulated in the NSRF described differences in the patterns of exclusion experienced by the Roma minority and other 'minority' groups, including women, migrants, and disabled people. This not only made social differences seem natural and permanent, but also divided Slovak society into 'givers' and 'receivers'. Empirical analysis of SF programming shows that such divisions reinforce political reluctance to use EU financial resources for the advancement of the 'deviant' sector of the population (Kostka, 2019). As commented by a local community representative: "Targeted projects simply inflamed the "us against them" talk and strengthened the perceptions that the Roma get a lot of money from the EU but refuse to integrate anyway.' ${ }^{15}$ The majority of the interviewed activists asserted that targeted SF projects were in fact 'corrective tools' used by the local authorities to change or alter 'problematic behaviour'. They insisted that SFs are used to buttress initiatives that are explicitly disempowering and even humiliating:

Funds are used to insert people into degrading low-paying jobs that are not sustainable in the long term - sweeping streets, emptying public toilets there is this strong perception that Roma cannot do anything else; this is really exploitation, not integration. ${ }^{16}$

The conceptualization of Roma exclusion in terms of culture and individual failing has also decoupled integration measures from national and regional development strategies, which in the end has severely offset the allocation rates and sustainability of the projects. Overall, the objectives stressing the need for institutional modernization fell silent on the issues of equality and integration, while Roma inclusion initiatives lacked structural components. What emerged was a 'double-tier system' with separate institutions, conflicting priorities, and incongruous measures. The incompatibility of integration initiatives with ongoing social policy trends confined the duration of the projects to a five-year funding period and hindered the scaling-up of successful local initiatives. As commented by a leader of a grassroots NGO:

Even if the SF project is successful, there is no interest to make it part of the political agenda. There is no interest to promote Roma issues because the authorities have very different plans and priorities. They often say that since we got the European money we should not expect anything else, or they claim that the legislation does not allow for the project to be scaled up. ${ }^{17}$

The double-tier dynamics also negatively affected co-financing. The majority of implemented ESF projects targeted at MRCs received only 15 per cent cofinancing from public budgets (the minimum amount stipulated by cohesion regulations), but in some cases projects were fully financed with SFs (in full breach of the additionality principle). These included the nation-wide Field Social Work 
and Community Centres programmes (Škobla et al., 2016). In many localities, the SFs were viewed as an 'additional pool of money' that could replace municipal budgets. In Bratislava, politicians consistently argued against budgetary provisions for the Roma population, insisting that Roma already receive 'excessive' amounts from Brussels. As explained by a member of the Monitoring Committee (MC):

Since the majority of projects are not connected in any way to wider reforms or social programmes, they are often sidelined during budgetary debates. There is this false pretence that the EU channels money directly to Roma, who spend it on dubious things. The truth is that Roma communities have limited access to any money, and the short-lived SF projects actually replace programmes that should be financed from the public budget in the first place. $^{18}$

Finally, the double-tier system lacked any coordinative mechanisms, and this exacerbated delays and weakened absorption rates. Because the objectives of competing SF projects were not aligned, a common purpose or integration strategy was not properly institutionalized. Different agencies with their own interests had no clear understanding of the work performed by other agencies. In 2007-2013, only $€ 16$ million out of $€ 200$ million were absorbed by Roma communities under the comprehensive approach (which for a long time was championed by the EC as good practice) (Hurrle, et al., 2012; Kostka, 2019). In the current funding period, the OP Human Resources has earmarked funds for the national programme Take-Away Package, which targets 150 marginalized Roma communities by offering funding for 'soft programmes' (field social work, mediation, and community centres). However, in 2017 less than 30 per cent of the funds had been contracted, out of 656 field social worker positions only 304 had been filled, and only 30 community centres were in operation (Roma Civil Monitor, 2018). The focus on kindergartens under the Take-Away Package has not been implemented at all. A local stakeholder pointed out that the reason for this is the complete disconnection of Roma issues from national and regional interests:

It seems that nobody is in charge of these Roma projects; they are being passed around different Ministries, with Plenipotentiary having no decisionmaking authority [...] it is like a whole different world fully isolated from the important things that the state is planning or doing. ${ }^{19}$

\section{Conclusions}

This chapter has argued that the framing of public problems influences the implementation of policies and their final outputs. The analysis of SF programming has confirmed that Roma exclusion is largely a constructed concept, 
underpinned by normative contentions about the causes of poverty. While policy-makers rely on empirical assessments to formulate the definitions of Roma exclusion, these assessments tend to be mediated by the existing cognitive and moral maps that orient their actions and routines. In turn, these politically accepted definitions legitimize a specific course of action, even if it is not needed or demanded by the targeted 'beneficiaries'.

This chapter has also shown that the cohesion policy framework has framed Roma exclusion in terms of individual or group adaptability with negligent attention given to general institutional inequalities and structural discrimination. The Slovak case proves empirically that this neglect enforces the channelling of funding towards measures that aim to change the behaviour of target groups, in this case Roma communities. The adopted targeted approach was supposed to offset the pervasive practice of re-directing funding from the most marginalized communities, but this has instead led to the isolation of Roma measures from regional and local development strategies and has had the effect of reinforcing the redirection of funding to other priorities. While targeting of funds at Roma communities appeared sensitive to the specificity of the conditions in the Roma settlements, it in fact contributed to the ethnicization of the problem. As confirmed by SF stakeholders, the opportunity for systemic transformation was effectively lost, and the Roma people could benefit only from short-lived training and consulting activities that were not linked to public services or to povertyreduction programmes.

Despite severe deficiencies, SFs are still peddled as the best tools to address the multi-dimensional aspects of Roma exclusion. However, the 2014-2020 period is slowly coming to an end, and various EU institutions have yet to agree on how the new provisions should work. What remains unopposed is the devotion to the targeted approach, now espoused by the EU Framework for National Roma Integration Strategies, community-led local development strategies (CLLDs), and various commitments adopted by the European Parliament, the European Ombudsman, and the ESF Learning Network on Roma Inclusion (launched in spring 2013). While targeting is unleashed with even more force, commitment of the general population regarding financial support explicitly for Roma inclusion is deteriorating. The latest policy survey, TARKI (2018), shows that the perception of the general population is that Roma receive more social aid than any other beneficiary group (e.g. pensioners, disabled people, and unemployed people) and that such support should be eliminated or curtailed. It is not difficult to imagine that such attitudes could be detrimental to the implementation of Roma-specific financial support because the resistance of the people involved would be high. However, international stakeholders continue to ignore this hostile environment, stubbornly insisting that ethnic targeting will eventually succeed. The dilution of mainstreaming strategies is puzzling because there is empirical evidence that strong resistance by the general population is only against financial support explicitly for Roma inclusion, not against investment in the improvement of access to and quality of mainstream education, employment, 
and healthcare services (Kullmann, 2015). While commentators insist that 'progress was made in terms of better linking Roma integration and the Europe 2020 Strategy' (Andor, 2018), this optimism is not reflected on the ground.

The endorsement of CLLDs mirrors the Local Strategies of Comprehensive Approach introduced in Slovakia, including all of their shortcomings such as a lack of strategic focus and a lack of clearly stipulated objectives. The technocratic nature of these interventions once again depoliticizes Roma representation, curtailing grassroots mobilization and obscuring accountability. More importantly, SF stakeholders still frame Roma communities as a 'social problem' in need of 'fixing' by expert-driven initiatives (albeit now more informed by local needs). Although policy experts maintain that community-led initiatives can help to mobilize and involve local communities in promoting integration, how this is to be achieved with SFs remains an enigma.

\section{Notes}

1 According to the European Parliament, the number of people at risk of poverty or social exclusion increased to 118 million persons, or 23.5 per cent of the population in the EU-28 in 2016 (this was 806,000 more than in 2008). However, this aggregated figure masks large variations across member states (Ciucci, 2018).

2 While Roma people reside in every country on the continent, they are located principally in Central and Eastern Europe. Following the consecutive EU enlargements in 2004, 2007, and 2011, the population today stands at about six million (European Union Agency for Fundamental Rights, 2018).

3 The marginalization of Roma people, while more acutely felt in CEE countries, is not confined to this region. Discrimination is widely spread across Europe. The recent migration of Roma from CEE countries to the West resulted in great hostility in all member states allegedly committed to diversity and equal opportunity (see Y1ldiz and De Genova, 2017).

4 Interview, Bratislava 2015.

5 Interview, Bratislava 2015.

6 Interview, Bratislava 2014.

7 Interview, Skalica 2011.

8 Interview, Bratislava 2015.

9 Overall, 139,000,000 euro was allocated under the priority (Operational Programme Human Resources, 2014).

10 Interview, Kosice 2015.

11 Interview, Kosice 2015.

12 Interview, Kosice 2015.

13 More than 90 per cent of these projects were awareness campaigns and promoted small cultural events (Frank, 2011).

14 Interview, Skalica 2011.

15 Interview, Skalica 2011.

16 Interview, Bratislava 2015.

17 Interview, Banska Bystrica 2011.

18 Interview, Bratislava 2011.

19 Interview, Bratislava 2015. 


\section{References}

Andor, L. (2018). EU policy and Roma integration (2010-2014). Journal of Poverty and Social Justice 26(1), pp. 113-126.

Bacchi, C.L. (1999). Women, policy and politics: the construction of policy problems. London: Sage Publications Incorporated.

Bachtler, J. and McMaster, I. (2008). EU Cohesion policy and the role of the regions: investigating the influence of Structural Funds in the new member states. Government and Policy 26, pp. 398-427.

Barany, Z. (2002). The East European Gypsies: regime change, marginality, and ethnopolitics. Cambridge: Cambridge University Press.

Brown, W. (2006). American nightmare: neoliberalism, neoconservatism, and dedemocratization. Political Theory 34(6), pp. 690-714.

Centre for Strategy and Evaluation Services (2011a). Evaluation of ESF Support for Enhancing Access to the Labour Market and the Social Inclusion of Migrants and Ethnic Minorities. Final Report, VT: 2009/058.

Centre for Strategy and Evaluation Services (2011b). Evaluation of ESF Support for Enhancing Access to the Labour Market and the Social Inclusion of Migrants and Ethnic Minorities, Roma Thematic Report.

Chelcea, L. and Druta, O. (2016). Zombie socialism and the rise of neoliberalism in postsocialist Central and Eastern Europe. Eurasian Geography and Economics 57(4-5), pp. 521-544.

Ciucci, M. (2018). People at risk of poverty or social exclusion. Economic Governance Support Unit. Directorate-General for Internal Policies. PE 614.487.

Drál, P. (2008). Symbolic processes of social exclusion of Roma in Slovak public policy discourse. Ethnicity Studies ISSN, 1822-1041.

Edelman, M. (1985). Symbolic uses of politics. Champaign: University of Illinois Press.

European Commission (2003). Comprehensive Monitoring Report on Slovakia's Preparations for Membership, [online]. Available at: https://ec.europa.eu/neighbourhoodenlargement/sites/near/files/archives/pdf/key_documents/2003/cmr_sk_final_en.pdf.

European Commission (2004). The Situation of Roma in an Enlarged European Union. Luxembourg: Publications Office of the European Union.

European Commission (2010a). Strategic Report 2010 on The Implementation of the Programmes 2007-2013 SEC(2010)360. COM(2010)0110 final.

European Commission (2010b). The European Platform against Poverty and Social Exclusion: A European Framework for Social and Territorial Cohesion. COM (2010)758 final.

European Commission (2010c). The Social and Economic Integration of the Roma in Europe. $\operatorname{COM}(2010) 133$ final.

European Commission (2011). An EU Framework for National Roma Integration Strategies up to 2020. $\operatorname{COM}(2011) 173$ final.

European Commission (2013). Cohesion policy: Strategic Report 2013 on Programme Implementation 2007-2013. COM(2013)210 final.

European Commission (2014a). Sixth Report on Economic, Social and Territorial Cohesion: Investment for Jobs and Growth. Brussels, 23.7.2014, COM(2014)473 final.

European Commission (2014b). Investment for Jobs and Growth - Promoting Development and Good Governance in EU Regions and Cities: Sixth Report on Economic, Social and Territorial Cohesion. Brussels: Directorate-General for Regional and Urban Policy Publication Office. 
European Commission (2016). Assessing the implementation of the EU Framework for National Roma Integration Strategies and the Council Recommendation on Effective Roma Integration Measures in the Member States. Brussels, 27.6.2016, COM(2016)424 final.

European Court of Auditors (2016). EU Policy Initiatives and Financial Support for Roma Integration: Significant Progress Made over the Last Decade, but Additional Efforts Needed on the Ground. Special Report, Luxembourg: Publications Office of the European Union.

European Parliament (2011). Measures to Promote the Situation of Roma EU Citizens in the EU. Brussels: Citizens' Rights and Constitutional Affairs.

European Parliament (2015). EU Framework for National Roma Integration Strategies. Study for the LIBE Committee. [online] Available at: www.europarl.europa.eu/thinktank/en/document.html?reference=IPOL_STU(2015)536485.

European Union Agency for Fundamental Rights (2018). Second European Union Minorities and Discrimination Survey. Roma - Selected Findings. Luxembourg: Publications Office of the European Union.

Farole, T., Rodriguez-Pose, A., and Storper, M. (2011). Cohesion policy in the European Union: growth, geography, institutions. Journal of Common Market Studies 49(5), pp. 1089-1111.

Frank, K. (2011). Expert Evaluation Network, Delivering Policy Analysis on the Performance of Cohesion Policy 2007-2013. Task 2: Country Report on Achievements of Cohesion Policy, Slovakia. Bratislava: Institute of Economic Research - Slovak Academy of Science.

Goffman, E. (1974). Frame analysis: an essay on the organization of experience. New York: Harper \& Row.

Goldberg, D.T. (2009). The threat of race. Reflections on racial neoliberalism. Malden: Wiley-Blackwell.

Hurrle, J., Ivanov, A., Grill, J., Kling, J., and Škobla, D. (2012). Uncertain impact: have the Roma in Slovakia benefited from ESF? Findings from an Analysis of ESF employment and social inclusion projects in the 2007-2013 programming period. Roma Inclusion Working Papers, UNDP Europe and the CIS, Bratislava Regional Centre.

Jovanovic, J. (2015). Why Europe's 'Roma Decade' didn't lead to inclusion. Budapest: Open Society Foundation.

Kendea, A., Hadaricsa, M., and Lášticováb, B. (2017). Anti-Roma attitudes as expressions of dominant social norms in Eastern Europe. International Journal of Intercultural Relations 60, pp. 12-27.

Kóczé, A. and Rővid, M. (2017). Roma and the politics of double discourse in contemporary Europe. Identities 24(6), pp. 684-700.

Kóczé, A., Kullmann, A., Scharle, A., Szendrey, O., Teller, N., and Zentai, V. (2014). Toolkit on programming the Structural Funds for Roma inclusion in 2010-20. Budapest: Making the Most of EU Funds for Roma program, Open Society Foundation.

Kooiman, J. (2003). Governing as governance. New York: Sage Publications.

Kostka, J. (2019). Financing Roma inclusion with European Structural Funds. Why good intentions fail. New York: Routledge.

Kovats, M. (2002). The European Roma question. Briefing Paper New Series Nr.31, London: The Royal Institute of International Affairs.

Kovats, M. (2012). The EU's Roma role. Open Democracy, [online] Available at: www. opendemocracy.net/martin-kovats/eus-roma-role. 
Kullmann, A. (2015). Litmus test of effective use of structural funds: supporting structural reforms of basic public services to promote Roma inclusion. European Structural and Investment Funds Journal 3(4), pp. 231-238.

Law, I. and Kovats, M. (2018). Rethinking Roma identities, politicisation and new agenda. Basingstoke: Palgrave Macmillan.

Magazzini, T. (2016). Cultural institutions as a combat sport. Reflections on the European Roma Institute. The Age of Human Rights Journal 7, pp. 50-76. ISSN: 2340-9592.

Marushiakova, E. and Popov, V. (2015). European policies for social inclusion of Roma: Catch 22? Social Inclusion 3(5), pp. 19-31.

Miller, P. and Rose, N. (2008). Governing the present. Cambridge: Polity Press.

National Strategic Reference Framework for 2007-2013, Slovakia. [online] Available at: www.nsrr.sk/en/narodny-strategicky-referencny-ramec-2007-2013/.

OECD (2017). Understanding the Socio-economic Divide in Europe. Background Report. Centre for Opportunity and Equality. [online] Available at http://oe.cd/cope-divideeurope-2017.

O'Nions, H. (2007). Minority rights protection in international law: the Roma of Europe. Burlington: Ashgate Publishing Company.

Open Society Institute (2010). Decade Watch Report: Results of the 2009 Survey. Budapest: Open Society Institute.

Operational Programme Education of the Slovak Republic for 2007-2013. Ministry of Education, Science, Research and Sport of the Slovak Republic.

Operational Programme Employment and Social Inclusion for 2007-2013. Ministry of Employment and Social Affairs of the Slovak Republic.

Operational Programme Human Resources for the programming period of 2014-2020. Ministry of Labour, Social Affairs and Family of the Slovak Republic.

Patton, M. (1990). Qualitative evaluation and research methods. Beverly Hills: Sage.

Picker, G. (2017). Racial cities. Governance and the segregation of Romani people in urban Europe. New York: Routledge.

Popa, A. (2012). The impact of the Structural Funds in the transformation process of the new EU member states. L'Europe En Formation 364, pp. 161-179.

Ram, M.H. (2014). Europeanized hypocrisy: Roma inclusion and exclusion in Central and Eastern Europe. Journal on Ethnopolitics and Minority Issues in Europe 13(3), pp. 15-44.

Richardson, S.A. (1965). Interviewing: its forms and functions. New York: Basic Books.

Roma Civil Monitor (2018). A Synthesis Report on Implementation of National Roma Integration Strategies in Bulgaria, Czech Republic, Hungary, Romania and Slovakia. Budapest: Centre for Policy Studies.

Rostas, I., Rovid, M., and Szilvasi, M. (2015). On Roma civil society, Roma inclusion and Roma participation. In: M. Bodgán, J. Dunajeva, T. Junghaus, A. Kóczé, M. Rővid, I. Rostas, A. Ryder, M. Szilvási, and M. Taba, eds., Roma rights, 2nd edn. Budapest: European Roma Rights Centre.

Sigona, N. and Trehan, N., eds. (2009). Romani politics in contemporary Europe: poverty, ethnic mobilization, and the neo-liberal order. Basingstoke: Palgrave Macmillan.

Sigona, N. and Vermeersch, P. (2012). Editors' introduction: the Roma in the new EU: policies, frames and everyday experiences. Journal of Ethnic and Migration Studies 38(8), pp. 1189-1193.

Škobla, D., Grill, J., and Hurrle, J. (2016). Exploring field social work in Slovakia. Evaluation of the programme funded by the European Social Fund in 2007-2013. Bratislava: Institute for the Research on Labour and Family. 
Smith, H.W. (1975). Strategies for social research. The methodological imagination. Englewood Cliffs: Prentice-Hall.

TARKI (2018). Policy analysis, social and economic research, surveys, statistics, data mining. [online] Available at: www.tarki.hu/en/.

United Nations (2016). Concluding Observations on the Fourth Report of Slovakia. Adopted by the Human Rights Committee at 118th session (17 October-4 November 2016).

Van Baar, H. (2011). The European Roma: minority representation, memory, and the limits of transnational governmentality. Amsterdam: University of Amsterdam.

Verloo, M. (2005). Mainstreaming gender equality in Europe. A critical frame analysis approach. The Greek Review of Social Research 117(B), pp. 11-34

Vermeersch, P. (2012). Reframing the Roma: EU initiatives and the politics of reinterpretation. Journal of Ethnic and Migration Studies 38(8), pp. 1195-1212.

Voiculescu, C. (2017). European social integration and the Roma. New York: Routledge.

Yildiz, C. and De Genova, N. (2017). Un/Free mobility: Roma migrants in the European Union. Social Identities 24(4), pp. 425-441. 


\title{
Policies for whom? Roma as ethnic and/or national minorities: the case of Hungary and the European Union
}

\author{
Andras L. Pap
}

\section{Introduction}

This chapter focuses on how Hungarian legislators have conceptualized Roma as a national minority. Besides an analysis of the development of the actual legislative framework since the 1989 political transition (see the second section of this chapter), in order to contextualize this project, the chapter outlines the conceptual framework in which the terminology of national-ethnic-racial minorities can best be understood (see first section). I argue that the conceptualization of 'what Roma are' and how Roma policies should be designed and targeted will be completely different when referencing rights holders for minority (cultural) rights, beneficiaries of social inclusion policies, or victims of discrimination. It will also be argued that while terminology in legislative and policy documents itself is not a reliable signifier for policy frameworks, it might reveal contradictory group conceptualizations and inconsistent policy-making. In assessing the Hungarian minority-rights framework (see third section), it will be claimed that the inconsistent labelling of Roma as an ethnic, racial, and national minority reflects the lack of consistent conceptualization and the determination of whether social inclusion, anti-discrimination, or a cultural rights-oriented approach should dominate policies. Two subchapters will investigate the explanatory value of post-communism and the broader context of ideological and institutional path dependence in these policies (see fourth section), and the peculiarity of the Hungarian case in the sense that conceptualizing the Roma as holders of minority rights and an identity group fostering nation building was conceived as a form of adhering to European integration norms and adapting crucial social inclusion policies (see fifth section). It is argued that both domestic and EU policy-makers appear to be insensitive to the difference between the tailored social-inclusion measures and a minority-rights framework that enhances minority identity.

In terms of methodological framing, the analysis follows a top-down perspective and focuses on legislative policies conceptualizing Roma as an ethnonational minority. The two major legislative instruments, the 1993 and 2011 laws on the rights of national and ethnic minorities and nationalities, are analysed in 
detail because these are core legal documents that provide an authentic interpretation of how the Hungarian legislature conceptualized the Roma. The analysis is carried out through scrutiny of the legal texts as supported and provided by international and non-governmental organizations as well as academic texts and secondary literature.

\section{Race, ethnicity, and nationality: clusters for conceptualizing groups}

The question often arises concerning the term 'Roma' - does it refer to a social class, ${ }^{1}$ a race, an ethnicity, or a national minority? In social sciences and law, the purpose of typologies and classification is to help us understand the internal logic and substance of concepts and institutions. Although the discourses on minority rights and adjacent policy frameworks are essentially law-based, most international and domestic documents on minority rights, human rights, and social rights only provide vague descriptions of race, ethnicity, and nationality. In order to evaluate and contextualize the potential policy ramifications of different conceptualizations of 'the Roma', the following subchapter will provide an overview of what race, ethnicity, and nationality can mean in reference to this unique, transnational, and multifaceted group with a diverse set of claims and a complex socio-political environment.

\section{Race and ethnicity: vague categories, inconsistent application}

Race is a controversial category. It is generally not considered to be a fruitful analytical concept in the social sciences, where it is widely understood to be a social construct rather than a biological trait (in the biological sense, the entirety of humanity constitutes one single race) without a theoretically or politically uniform definition (e.g. see Tajfel 1981). For a legal analysis, however, there are calls for some sort of definition, conceptualization, and analysis because countless domestic and international legal documents apply the term either in conjunction with 'ethnicity' or alone when setting forth the prohibition of discrimination, genocide, hate crimes, and other forms of persecution and marginalization. Hence, the conceptualization of the term is inevitable. The aforementioned legal instruments for the most part identify race with physical appearance, and they put perception and external classifications in the centre when prohibiting discrimination or violence (on racial grounds). In this, race is rarely distinguished from ethnicity, and the two terms are often used interchangeably by lawmakers (and drafters of international documents) and most of all by judicial bodies.

For example, under Article 1 of the 1965 International Convention on the Elimination of All Forms of Racial Discrimination, "the term "racial discrimination" shall mean any distinction, exclusion, restriction or preference based on race, colour, descent, or national or ethnic origin'. Despite academic interest and 
an insistence on differentiating between the two concepts, legal formulations seem to be incognisant, and even appear to be unobservant and indifferent concerning a potential difference between the two terms.

For example, in Koptova v. Slovakia (OHCHR 2000) and Lacko v. Slovakia (OHCHR 2001), the UN Committee on the Elimination of Racial Discrimination (hereinafter CERD), the body in charge of supervising the aforementioned treaty, had no qualms about accepting complaints concerning the treatment of Roma, thus recognizing them as a racial group (Guglielmo 2004, 10). The Grand Chamber of the European Court of Human Rights (ECHR), spoke about racial discrimination against members of the Roma minority when ruling against the Czech Republic in the segregation case of Case of DH and Others v. The Czech Republic (2007). Most judicial bodies have no qualms about applying race and ethnicity as synonymous. In Chapman v. The United Kingdom (2001), the very same ECHR accepted that gypsies constituted a distinct ethnic group in Britain by saying, '[T]he Applicant's occupation of her caravan is an integral part of her ethnic identity as a gypsy.' The ECHR's terminological assessment in the Sejdic and Finci v. Bosnia and Herzegovina judgment further complicates the issue:

Ethnicity and race are related concepts. Whereas the notion of race is rooted in the idea of biological classification of human beings into subspecies on the basis of morphological features such as skin colour or facial characteristics, ethnicity has its origin in the idea of societal groups marked in particular by common nationality, religious faith, shared language, or cultural and traditional origins and backgrounds. Discrimination on account of a person's ethnic origin is a form of racial discrimination.

(Case of Sejdić and Finci v. Bosnia and Herzegovina, 2009: 43)

In Ireland, travellers have formally been recognized as an ethnic minority (O’Regan and O'Halloran 2017), and Romani and Gypsy (used interchangeably) and Irish Travellers have been held to be 'ethnic' groups for the purpose of the Race [sic! - ALP] Relations Act in the UK. (See, for example, Commission for Racial Equality v. Dutton (1988), McVeigh (2007). See also: O'Leary v. Allied Domecq (2000), Wrexham County Borough Council (Appellants) v. Berry (Respondent), South Bucks District Council (Appellants) v. Porter and another (FC) (Respondents), Chichester District Council (Appellants) v. Searle and others (Respondents) (Consolidated Appeals) (2003 at paragraph 41). In Hallam v. Cheltenham Borough Council and Others (2001), the House of Lords also held that a local council's refusal to let public rooms to a Gypsy family for a wedding amounted to discrimination on racial grounds for the purposes of the Race Relations Act.

As far as international law goes, the Permanent Court of International Justice held in the Case of Greco-Bulgarian Communities (1930) that a minority community is: 
a group of persons living in a given country or locality, having a race, religion, language and traditions of their own, and united by the identity of such race, religion, language and traditions in a sentiment of solidarity, with a view to preserving their traditions, maintaining their form of worship, securing the instruction and upbringing of their children in accordance with the spirit and traditions of their race and mutually assisting one another.

(Greco-Bulgarian Communities 1930: 30)

We can argue that if we want to grasp the substance of these definitions, in the racial and ethnic minority concept there is one common element - the protection from maltreatment, including discrimination, hate crimes, hate speech, and physical violence. Reflecting an anti-discrimination logic, the groups need to be defined by following the perpetrators' method - basing the definition of the group on the perception of either biologically determined characteristics or cultural attributes.

In a sense, however, ethnic minorities are multifaceted groups. While many of their claims are grounded in the anti-discrimination rhetoric employed by racial minorities, some 'ethnically defined' groups, such as Roma, might also have similar cultural claims (and protections) that national minorities might make. The international legal terminology habitually differentiates between the two groups on the grounds that ethnic minorities are different from national minorities in the sense that they do not have nation states as national homelands (Hannum 2000). In this way, ethnic minorities are a sort of hybrid categorization, blending, and often mirroring, the claims made by racial and national groups.

The probably most important international document on national minorities, the 1995 Council of Europe Framework Convention for the Protection of National Minorities, also fails to provide a definition for its targets. ${ }^{2}$ A relevant definition, also endorsed by the European Parliament's 2005 resolution on the protection of minorities and anti-discrimination policies in an enlarged Europe, is provided by the 1993 recommendation (no. 1201) of the Parliamentary Assembly of the Council of Europe in an additional protocol regarding the rights of national minorities in the European Convention on Human Rights:

National minority refers to a group of persons in a state who: reside on the territory of that state and are citizens thereof; maintain longstanding, firm and lasting ties with that state; display distinctive ethnic, cultural, religious or linguistic characteristics; are sufficiently representative, although smaller in number than the rest of the population of that state or of a region of that state; are motivated by a concern to preserve together that which constitutes their common identity, including their culture, their traditions, their religion or their language.

(Additional Protocol on the Rights of Minorities to the European Convention on Human Rights 1993) 
When it comes to defining national minorities, I offer to settle with a definition that these are groups that, based on their claims for collective rights, bypass the anti-discriminatory logic and seek recognition of cultural and political rights, especially autonomy and the toleration of various cultural practices that differ from the majority's and which often require formal exceptions from generally applicable norms and regulations. In this case, we are dealing with claims for preferential treatment. According to Will Kymlicka (2001), cultural minorities can be divided into nations and ethnicities. The former is a historical community, more or less institutionally complete, occupying a given territory or homeland, and sharing a distinct language or culture, while the latter is a group with common cultural origins but whose members do not constitute an institutionally complete society concentrated in one territory.

\section{Means to an end: concepts of justice and social policy}

These questions cannot be separated from discussions concerning what concept of social justice and equality decision-makers are endorsing in regard to a given community. Fraser (1995) points to the difference between redistribution and recognition goals (and the importance of both in the long run), and McCrudden (2005) suggests that there are at least four different meanings of equality, and what might be suitable in one context might not be suitable in another. First, what he calls the 'individual justice model' focuses on merit, efficiency, and achievement and aims to reduce discrimination. Second, the 'group justice model' concentrates on outcomes and on the improvement of the relative positions of particular groups, with redistribution and economic empowerment at its core. Equality as the recognition of diverse identities is the third dimension because the failure to accord diversity is a form of oppression and inequality itself. Finally, the fourth conception of equality includes social dialogue and representation, in other words, the meaningful articulation of group priorities and perspectives (ibid.). Each of these conceptions of equality also has a different concept at its core, corresponding respectively to direct discrimination; indirect discrimination and group-level marginalization and oppression; cultural and linguistic rights; and participation in political and public policy decisions.

A useful set of terminology therefore should centre on the substance of legal and policy claims and frameworks. Under this approach, there are three clusters. First, minority rights have the recognition and accommodation of cultural claims of both groups and individuals, as well as identity politics, in focus. The second array of legal and policy frameworks is oriented towards individual rights and has anti-discrimination in focus. The term should be understood in the broad sense, including protection from hate crimes, or even hate speech, and several other related individual-based human rights claims. The third batch includes those various and diverse social inclusion measures that 'ethnicize' social policies or, when endorsing multiculturalism, include the recognition of other forms of group-based, collective claims. 'National minorities' and 'nationalities' are 
adequate terminologies for the first cluster, 'racial' and 'ethnic' minorities are adequate for the second cluster, and the third approach institutionalizes a curious mix of all three clusters.

It needs to be emphasized, though, that the recognition of ethno-cultural claims and policies for enhancing certain groups' capabilities for participating in cultural and public life, and to preserve their identities, needs to be differentiated from measures providing equal treatment or setting forth group-conscious social policies. Due to the uniquely complex situation of Roma, what we will see in our Hungarian case study is that Roma policies are the chaotic application of all of the above.

\section{The Hungarian minority-rights legislative framework}

In 1993 Hungary adopted a comprehensive law on the rights of national and ethnic minorities. The law defined national and ethnic minorities as groups that have been present in the territory of Hungary for over 100 years and that:

constitute a numerical minority within the population of the country, whose members hold Hungarian citizenship and differ from the rest of the population in terms of their own tongue, cultures and traditions, and who prove to be aware of the cohesion, national or ethnic, which is to aim at preserving all these and at articulating and safeguarding the interests of their respective historically developed communities.

The law also enumerated the following 13 recognized minorities: Armenian, Bulgarian, Croatian, German, Greek, Polish Romanian, Ruthenian, Serb, Slovak, Slovenian, Ukrainian, and Roma. A complicated procedure was set forth to extend the list, and this involves a popular initiative, an advisory opinion of the Hungarian Academy of Sciences, and a vote in the Parliament amending the Act. No such initiatives have been successful so far. The Act guarantees cultural and linguistic rights for these groups, and it contains provisions on the establishment and maintenance of minority education and establishes a unique Hungarian institution, the minority self-governments (MSGs). Funded by the local authorities or by the State where national-level bodies are concerned, MSGs are elected bodies that operate at the local, regional, and national level and that have special competences for protecting cultural heritage and language use, fixing the calendar for festivals and celebrations, fostering the preservation of traditions, participating in public education, managing public theatres, libraries, and science and arts institutions, awarding study grants, and providing services for to the community (legal aid in particular) (Darquennes et al., 2012):

The function and design of MSGs is quite ambiguous: political representation and empowerment, cultural competences, and a vague promise of social 
integration potential are bundled together. In 2006, the Office for Democratic Institutions and Human Rights of the Organization for Security and Co-operation in Europe (OSCE/ODIHR 2014) published a detailed report (NDI, OSCE/ODIHR 2006) and pointed to many problems with the system. ${ }^{3}$ These included unclear competencies, the lack of differentiation between various minority needs, deficiencies in financing, and voter enfranchisement regardless of ethnic affiliation.

According to the report, the institution of MSGs is:

tinkered with a fundamentally flawed concept that offers the illusion of political power rather than genuine inclusion (NDI, OSCE/ODIHR 2006, 4-7). [...] The MSG system [...] functions more like NGOs than elected governing bodies. The [...] term 'self-government' $[\ldots]$ raises unrealistic expectations [and] the very design of the system prevents it from having a significant impact on issues of greatest concern to most.

The OSCE also points to flaws in funding, claiming that financial support is inadequate to carry out socio-cultural projects, and most MSGs cannot even cover a modest salary for a part-time employee.

Another controversial element of the legal framework relates to what is commonly known as 'ethno-business' or 'ethno-corruption'. Deets (2002) documents how school officials pressure parents of 'Hungarian' students to declare their children 'German'. He states, 'According to Hungarian government statistics, in 1998, almost 45,000 primary school students were enrolled in German-minority programs, which, by the census, was about 8,000 more than the number of ethnic Germans who are even in Hungary.' The minority rights ombudsman also pointed out that in the 2001 census 62,233 people claimed to be German, while there were 46,693 students enrolled in the German minority education scheme (The Minority Rights Ombudsman 2011,39), and there was German minority education in several municipalities where neither the 2001 nor the 1944 census (which predated the mass expulsion of some 380,000 ethnic Germans from Hungary) indicated the presence of a German community. Sometimes educational segregation is achieved by Roma parents being pressured to request specialized minority education, aimed originally at safeguarding Roma culture (Balogh 2012a, 2012b; Balogh et al., 2013). The result is that Roma children are provided low-quality Roma folklore classes once a week, but are kept in separate, segregated classes in inferior conditions. ${ }^{4}$

MSG elections have also been constant sources of fraud because the right to vote at these elections has not been curtailed by any restrictions. After repeated reports of the permanent abuse of the electoral scheme, in 2005 a 'soft' form of registration was implemented, where minority voters need to sign up in a special register, but no objective criteria or formal requirements for affiliation have been set forth. This also enables members of the majority to abuse the system by 
taking over the MSGs. For example, the non-Roma wife of the mayor of Jászladány - a village notorious for segregating Roma primary school children from non-Roma students - held an elected office in the local Roma MSG.

According to a poll by the think tank Századvég in December 2012, 49 per cent of Hungarians had heard about candidates running in minority elections without actually being a member of the given group (Magyar Nemzet Online 2012). Carstocea (2011, p. 20) showed that about 40 per cent of the Romanian self-governments were reported to be headed by non-Romanians. At one point, the faction of the National Ukrainian Self-government failed to stand up during the Ukrainian national anthem, and claiming that they were Hungarian requested that no Ukrainian be spoken during official sessions because they did not understand it (Index.hu 2011; Nol.hu 2011).

These loopholes in the legal regime sometimes result in complete absurdity. For example, in order to express their admiration of German football, a small village's entire football team registered as German minority candidates (Heizler 2002). In 2010 the mayor of a marginalized village at the edge of bankruptcy, unable to finance its public school, requested that all 13 students declare themselves Roma and request minority education because this qualified the school for extra funds even though no Roma officially lived in the village (Nagy 2010).

Prime Minister Viktor Orbán's Fidesz party gained a supermajority in 2010, allowing him to reformulate the constitutional and public law landscape, and a new minority law was adopted. Act CLXXIX of 2011 on the Rights of Nationalities Act basically preserved the earlier institutional and conceptual framework. However, the new law brought a peculiar change in terminology - something one might expect when reconceptualization is taking place in the background. 'National and ethnic minorities', which were the subjects and 'objects' of the old law, was changed to 'nationalities', and 'nationality self-government' replaced the old term 'minority self-government'. There is no evidence (for example, in parliamentary debates or government documents) that this shift in terminology was based on overarching theoretical or conceptual reasoning or that it has been accompanied by systematic political commitments.

An important provision of the new law concerns sui generis parliamentary representation for the recognized minorities, a question that has been on the agenda of Hungarian politics and legislation since the 1989 political transition. The 13 recognized minorities are now entitled to win preferential seats, one per community, in the 199-seat Parliament, and nomination of candidates is the prerogative of the national-level self-governments. Citizens can choose to vote either for a party or for their respective minority list. It takes only a relatively small number of votes, approximately 20,000-25,000, to gain a preferential mandate, but still, given the demographics of minorities in Hungary, only the Roma and the German minorities have a chance of actually succeeding in passing this threshold. Given the continuous tradition of ethno-corruption and the Orbán government's well-documented gerrymandering efforts, some argue that this might have been a non-negligible motivation for the legislation (Pap 
2018). In the 2014 elections, no minority representatives were elected, and in 2018 only a single German, who happens to be a member of Orbán's Fidesz Party, was elected. (The new legislation also introduced the institution of the nationality advocate, a non-voting member of the House who can submit bills and address the floor on behalf of those minorities that failed to elect an MP.)

Having outlined the general features of the Hungarian multicultural legal framework, let us turn our attention to the nation's only ethnic minority.

\section{Roma in the Hungarian minority-rights legislative framework}

\section{Roma in Hungary}

According to the Council of Europe, the cultural rights and situations of new minorities (immigrants) is a marginal issue in Hungary. Immigration figures are very low, and the overwhelming majority of immigrants are ethnic Hungarians from neighbouring states and who do not constitute a cultural minority. With an overall population of about 10 million, the immigration authorities recorded 213,000 foreigners living legally in Hungary in 2012 (Council of Europe \& ERICarts 2010). In the 2011 census, 6.5 per cent of the population declared that they belong to one of the minority groups.

According to the Council of Europe, about 7 per cent of the total Roma population lives in Hungary (2010), and Roma constitute the largest minority group in the country. In the 2011 population census, about 3.2 per cent of the population, 308,957 people, identified as Roma (Hungarian Central Statistical Office 2013), but the Council of Europe (2010) suggests that the real number might be closer to $700,000-1,000,000$ people. In Hungary, Roma are practically the only visible minority and have been present for centuries. Roma in Hungary are linguistically assimilated - practically all speak Hungarian, with some only speaking Hungarian and others being bilingual - and they do not differ significantly from the majority in terms of religious affiliation. Also, Roma in Hungary live a sedentary lifestyle - unlike some Roma communities in Europe - and only a very small group of Sinti (estimated to be less than 1 per cent among the Roma population, some operating travelling carnivals/carousels) are semi-sedentary (Szuhay 2003).

The Hungarian Roma population is very diverse, and there are three main groups (and several subgroups) of Roma in Hungary in terms of cultural and linguistic characteristics. These include the Romungros - who are linguistically assimilated and speak Hungarian as a mother tongue, the Boiash - many of whom speak a language that is based on an ancient version of Romanian, and those who also speak different dialects of the Romani language (the most widespread group is the Lovari) (Janky and Kemény 2003). The Hungarian Roma community is extremely diverse and heterogeneous and is unified only by the 'othering' of the majority and by the political concept of Roma as constituted by 
state policies and to a very limited degree by the international Romani movement (e.g. see Fosztó 2003).

\section{The 1993 framework}

When it comes to Roma, the function and the design of the MSGs is quite controversial. Generally, while acknowledging that the MSG system serves as a 'training school' for up-and-coming Romani politicians, giving them skills that they can use in the mainstream political arena, observers are quite critical of the institutional design (Kovats 1996; Thornberry 2001; Barany 2002; Majtényi 2005, 2007; Curejova 2007). As Melanie Ram (2014) notes:

[the MSG system], which at times has been touted as a possible model for other countries, has not brought a substantial improvement in Roma lives. While it has increased participation of Roma to some extent, it has hardly enhanced social inclusion of Roma, largely because its mandate is limited to cultural autonomy (basic education, media, language, and promotion of culture. The language provisions are simply not so helpful for a community that largely speaks Hungarian at home, and local self-governments do nothing to directly address either discrimination or socioeconomic inequalities.

(Ibid., 31)

According to one of the aforementioned reports, 'the MSGs tend to marginalize Romani issues by depositing them in a parallel, fairly powerless, quasigovernmental structure rather than addressing them through established governing bodies' (NDI, OSCE/ODIHR 2006, 6)

[...] Roma often approach their MSG expecting assistance related to a broad number of issues including housing, employment, discrimination and utility services. [...] in areas where the MSG has no mandate. [...] This lack of authority leaves MSGs as a 'half-way house' between a government institution and an $\mathrm{NGO}$, with an undefined, under-funded mandate. [...] As consultative bodies, the MSGs have not proven to be effective in promoting Romani interests on a broad array of mainstream policy debates.

(Ibid., 22)

[...] While other minorities are primarily concerned with protection of cultural and linguistic autonomy, the Roma population faces an almost opposite challenge, needing more integration to combat segregated education, discrimination, unemployment, and problems with housing and healthcare.

(Ibid., 5)

Cahn argues (2001) that the framework is not only 'largely inappropriate for addressing the situation of Roma', but has also 'reified the exclusion of 
non-white minorities in Hungary', and Hungarian Roma leaders repeatedly call for a redistribution-oriented, rather than a recognition-oriented, minority policy. ${ }^{5}$ According to Molnár and Schaft (2003):

Roma self-governments see as their main objective the improvement of social conditions in their community rather than the preservation of minority culture and the strengthening of minority identity. The ambitions of local Roma leaders are influenced primarily by the marginalization of their community, while the protection of Roma identity remains secondary.

(Molnár and Schaft 2003, 41)

To be fair, as Vizi (2013) points out, despite all its flaws, for the first time in Hungarian history the 1993 law formally recognized Roma as a group with legitimate claims for a separate identity. Admittedly, the law facilitated a peculiar nation-building project (see for example Fosztó 2003) by conceptualizing a Roma national minority as a distinct political group and incorporating all of its diverse subgroups. Also, the law to a certain degree successfully endorsed cultural aspirations of certain Roma communities and created a Roma political elite (Bíró 2013). On the other hand, its declaration concerning the prohibition of discrimination, a daily experience of Roma in Hungary in all facets of life, received very little attention. For example, the first comprehensive anti-discrimination law was adopted only in 2003, ten years after the minority rights law, and this law was necessitated only by EU-accession obligations, while in 2000, only three years before the law's adoption, the Constitutional Court rejected complaints pertaining to the lack of such legislation (Hungary: Decision No. 45/2000 (XII. 8.) 2000). Thus it is not surprising that the law was unfit to meet the dire need for social inclusion among Roma communities. Despite the shockwave of the market economy that hit the impoverished Roma the hardest, in the first decade or so after the political transition there were no serious attempts to institutionalize social inclusion measures targeting Roma because Hungarian legislators' priorities concerned enhancing exportable cultural identities for national minorities. Yet again, this particular piece of legislation never had such aspirations.

Another important remark needs to be made in defence of the 1993 framework, and as controversial as it might have been to conceptualize Roma as a national minority (especially because of the lack of a massive grassroots Roma 'nationalist' cultural and political elite at the time), it would have been politically and morally unacceptable to exclude Roma from the communities that the minority rights act was to enumerate and address. (It is important to note that, as Judit Sansum Molnár [Sansum Molnár 2017, 186] points out, 'Roma' was the most commonly used word in the almost year-long debate over the 1993 bill and was used almost twice as often as 'German' or 'Slovak', which were the next most commonly used.) 


\section{From ethnic to national minorities: the post-2010 framework}

The new 2011 Hungarian Constitution and the subsequently adopted new Act on the Rights of Nationalities (Hungary: Act CLXXIX/2011 on the Rights of Nationalities 2011) (i.e. minorities) which, as mentioned above, re-labelled Hungarian minorities from 'national and ethnic minorities' ('nemzeti és etnikai kisebbségek') to 'nationalities' ('nemzetiség'), officially replaced the term 'cigány' with 'roma'. Otherwise the new law brought no significant changes in conceptualization or even legislative text concerning the recognized groups.

There is no indication in parliamentary debates and government documents that abandoning the 'ethnic' and 'minority' terms had Roma in mind. During the drafting of the new constitution in 2011, the Croatian ('AEB/139/2010' 2010) and the Ruthenien ('AEB/136/2010' 2010) national MSGs welcomed the change in terminology, which was also recommended by the minority rights ombudsman. The Roma MSG remained silent.

One can argue that to (re)label a piece of legislation that focuses on collective (national) minority rights as an act on nationalities makes it conceptually solid and more coherent, leaving claims and policies that relate to other ethnic minorities to other legislative endeavours. A rather curious development, however, concerns Roma, and only Roma MSGs, because they have formally been involved in social inclusion measures, creating an even more confusing hybrid, mutant model. As Annex 2 to the first version of the Hungarian National Social Inclusion Strategy (2011), Hungarian National Social Inclusion Strategy II (2014), the government signed a framework agreement with the National Roma Self-Government, and competences such as supervising the schools, developing new employment schemes, and monitoring programmes have been assigned to it. In fact, it has been appointed as one of the core implementing bodies of the Strategy.

The new legislation clearly signals that on the one hand the legislature conceptualizes Roma issues foremost as issues of identity politics. On the other hand, government rhetoric and initiatives use cultural identity as a tool for social integration and present it in a simplified, essentialist manner. ${ }^{6}$ For example, the updated version of the integration plan (2014) under the auspices of the Hungarian National Social Integration Strategy (2011), which was adopted in order to reflect policy aims set forth by the European Framework for National Roma Integration, calls for the integration of a social-inclusion approach to Roma educational and cultural programmes (Dinók 2012).

Flaws in the Strategy and its policy environment have been thoroughly criticized in the monitoring report commissioned by the Decade of Roma Inclusion Initiative ${ }^{7}$ and compiled by a coalition of most of the relevant $\mathrm{NGOs}^{8}$ in Hungary (Balogh et al. 2013). For example, the report points out that:

[s]ome of the missing policies are closely connected with anti-discrimination and equal opportunities policies. [...] Abolishing the institution of the 
Parliamentary Commissioner for the Rights of National and Ethnic Minorities [... has] resulted in far less powerful institutional tools for combating discrimination. Hungarian authorities do little to sanction hate speech, and criminal law provisions designed to protect groups facing bias are more often applied by the authorities to sanction Roma rather than non-Roma. In the case of most hate crimes, no proper criminal procedure is launched. Romani women and children suffer extreme forms of exclusion, too. At the local level, the powerless position of minority self-governments has been further weakened: their consent is not obligatory any longer to decide on matters affecting the local Romani community.

(Ibid., 9-10)

Also, 'the circumstance that public security measures are connected with the measures aimed at Roma inclusion is quite problematic, since this gives the impression that ethnic origin is connected to criminality' (Balogh et al. 2013, 37).

Again, to be fair to the Hungarian legislature, the following points need to be made. First, the minority rights framework is not to be blamed for what it does not aim for, and it does not claim to be the materialization of a holistic project for all minority and Roma-related issues. It is a piece of legislation focusing on culture-centred collective rights. Second, it should be mentioned that it would have been politically impossible not to include Roma in the enumeration of minority communities unless there would have been a straightforward rejection of this as was the case of the Jewish community (the representatives of which clearly expressed their desire to be left out of the 1993 framework). While the 2011 relabelling arguably only clarified the scenario, an overall valid criticism to conceptualizing Roma as foremost a national minority is that it derails public and political discussion and perception and weakens problem-sensitivity and shifts the focus from other, arguably more urgent issues such as poverty, social exclusion, and discrimination.

\section{The post-communist condition and historical path dependence}

When legislative policies in the new democracies of Central-Eastern Europe (or in the case of Hungary, one might argue, in a new non-democracy) are analysed, the explanatory force of the post-communist condition often comes up. In the case of Hungarian multiculturalist policies, even though the collapse of the communist regime made way for a newly formatted nationalism, the sources of pathdependence go even deeper in history. Debates and theories applied to multiculturalism in a diversity management context need to be adjusted accordingly when talking about Hungary, and discussions on Hungarian minority rights and policies need to reach back to 1920, when in the Treaty of Versailles that concluded the First World War Hungary lost two-thirds of its territory and the 
corresponding population to its neighbouring states. (This also led to a dramatic increase in the ethnic homogeneity of post-WWI Hungary.) Ever since, the aspiration to reunite the old glory and territorial integrity, or at least a sense of responsibility for ethnic kin in the neighbouring countries, has been a cornerstone of conservative (and also liberal dissident and anti-communist [see Pogonyi 2015]) domestic politics, and after the political transition in 1989 this has also been seen as a constitutional responsibility and a foreign policy priority.

Throughout the 1990s, when new Central and Eastern European democracies were torn between meeting requirements for European integration and giving in to nationalists revivals, the Hungarian governments made use of all the tools they had available to strengthen ties between the national homeland and ethnic kin in the diaspora. Bilateral agreements on minority rights were negotiated and signed with neighbouring states (Jeszenszky 1996), Hungary joined European minority rights treaties and conventions that focused on traditional, national minorities (such as the Framework Convention for the Protection of National Minorities and the European Charter for Regional or Minority Languages), and governments did everything in their power to pressure neighbouring states to do the same. Of course, their status and position was completely different - Hungary was practically ethnically homogeneous in terms of national minorities, with only a single ethnic minority, Roma. In 1990 , only 271,000 people ( 2.6 per cent of the total population) out of the 10.4 million inhabitants of Hungary claimed to have an ethnic background other than Hungarian; thus 97.8 per cent declared themselves to be Hungarian (Tátrai, 2015).

Many argue that the reason why the first right-wing conservative government elected after the political transition adopted an extremely generous model for accommodating multiculturalism for indigenous minorities - meaning traditional national minorities, and specifically those with homelands in the neighbouring states with large Hungarian minorities - was to create an indirect tool to provide a politically marketable model and example for the neighbouring countries. As the OSCE noted:

The government's stated purpose for creating the Minority Act was to assure the cultural autonomy of minorities [...] However, another important factor in the development of the act was Hungary's desire to protect the rights of the large number of ethnic Hungarians living in neighbouring countries. By developing the MSG system and other minority institutions, the government hoped to build leverage that it could use in bi-lateral negotiations with neighbouring states on guaranteeing the rights of Hungarians living abroad.

(NDI, OSCE/ODIHR 2006, 10)

This explains the inadequateness of the legislative framework regarding Roma. 


\section{The Hungarian regime in the European policy context}

The peculiarity of the Hungarian case is also in that conceptualizing Roma as holders of cultural and political minority rights, identity fostering and nation building were conceived as a form of adhering to European integration norms and of adapting crucial social inclusion policies. Arguably, both domestic and EU policy-makers appear to be insensitive to the difference between tailored social-inclusion measures and a minority-rights framework that enhances minority identity.

As analysts have pointed out, in order to minimize unwanted mass migration after accession, the EU made efforts to facilitate the social inclusion of the marginalized Roma communities during the accession process (Vermeersch 2003; Guglielmo 2004; Vizi 2005). Following a thorough analysis of accession reports, Vizi (2013) showed that there was no recognition or commitment to a separate assessment of assimilation, integration, and inclusion strategies that build upon and rely on a separate and special ethno-cultural identity. Given the heterogeneity of Roma in Hungary and the very advanced degree of their assimilation, this was a severe omission. In a way, although doing the opposite, the European Commission turned out to be just as obtuse, blindfolded, and conceptually disoriented as the Hungarian legislature. Even though annual accession progress reports and documents adopted by the European Parliament and the Commission discussed Roma-related issues under 'minority rights' labels, recommendations and concerns only focused on anti-discrimination, very broad social integration measures, and complaints against the treatment of Roma by the police and other authorities - none which actually have much to do with minority rights (Vermeersch 2008). Even the question of the parliamentary representation of minorities was seen as a tool for addressing social integration (Vizi 2013). Also, the preservation of cultural identity was never raised within accession progress reports.

Despite these ambiguities concerning the conceptual framework of EUaccession demands, analysts agree on the pressure it put on Hungarian policymakers to facilitate Roma social inclusion, which certainly improved after 1997. (It needs to be added that some argue that this might also have been due to the fact that this was the time when the inadequacy of the 1993 law was becoming apparent to the governments.) Even though the first government resolution on Roma integration was adopted in 1995 (Hungary: Government Resolution No. 120/1995. (XII. 22.) 1995), 1997 marked a significant expansion in the number of government documents (Hungary: Government Resolution No. 1093/1997 (VII. 29.) 1997; Hungary: Government Resolution No. 1048/1999 (V. 5.) 1999; Hungary: Government Resolution No. $1186 / 2002$ (XI. 5.) 2002; Hungary: Government Resolution No. 1021/2004 (III.18.) 2004), strategies, action plans, etc., that were adopted and the broadening of the perspectives within such documents (Vizi 2013). Recognizing its policies as successful, during the accession process 
the EU granted Hungary a significant amount of support for Roma integration as part of the Phare programme, and this included 18 million euro between 1999 and 2001 and altogether 34.5 million euro between 1999 and 2006 (National Development Agency, Hungary 2008).

Focusing on the European level and calling for a better and broader conception of 'Roma representation', Vermeersch and Van Baar (2017) emphasize the fallacies of one-sided Roma policy programmes:

Policies that focus primarily on minority rights (recognition) tend to neglect the detrimental dynamics of socioeconomic interactions between the Roma and others, while those that focus narrowly on social inclusion (redistribution) 'forget' to increase measures against discrimination, human rights abuse and 'Romaphobia' [... and] the dialogue with the Roma themselves at both 'elite' and 'grassroots' levels in devising, implementing and evaluating these policies - a methodology that is often dubbed 'Roma participation' or 'Roma representation'.

(Ibid., 122)

They claim that having recognized the ethnic specificity of Roma as 'non-regular' societal subjects, the EU has tried, but not succeeded, to strike a balance between redistribution and recognition, that is, a culturalized 'framing' of Roma and a stronger emphasis on society-wide structural causes. They acknowledge the

EU's policy trajectory towards a combination of, on the one hand, minority rights promotion, anti-discrimination laws, and cultural initiatives in the field of anti-racism and Holocaust remembrance with, on the other hand, policies that are explicitly dedicated to social inclusion and the application of regional cohesion and development funds to Roma issues.

(Ibid., 123)

Van Baar and Vermeersch emphasize, however, that:

valorizing or even reifying (ethnic) difference has not been the direct result of the merging of rights discourses and neoliberalism but, rather, of the latter's 'sustained assault on the very idea of egalitarian redistribution' [as the] combined politics of recognition and redistribution turned into a rhetorical battle about who were the 'deserving' welfare beneficiaries, and, by extension, who were the 'non-deserving'. It also popularized the idea that a distinction should be made between those 'able and willing' to adapt to the post-socialist conditions and those who are socio-economically or even racially 'inadaptable'.

(Ibid., 127-128)

All of this resonates with well-researched and thoroughly discussed debates on the politics of 'recognition' and 'redistribution'. For example, Themelis 
(2015), Voiculescu (2017), Van Baar (2011), and Kóczé and Rövid (2017) emphasize the controversial nature of the politics of 'double discourse' that speak to different audiences in relation to Roma in contemporary neoliberal Europe, where on the one hand, the integration, rights, and equal opportunities of Roma are promoted by a pro-Roma global microcosm of non-governmental and intergovernmental organizations, various national and local bodies, activists, experts, and politicians, as well as international policy frameworks such as the EU Framework for National Roma Integration Strategies, and previously the Decade of Roma Inclusion as well, while the recognition of, and ways to address, enduring structural violence and rising social insecurity is denied, and this rhetoric masks rather than challenges the structural oppression and inequality faced by Roma under the current conditions of neoliberal capitalism. They also point to how various discourses might both reinforce paternalistic policies and trigger divisive rhetoric. For example, when it comes to social inclusion, a similar rhetoric is used in the discourse on 'refugees' differentiating between 'fake', 'undeserving', 'economic', and 'poverty' migrants on the one hand, and 'real', 'deserving', and 'persecuted' refugees on the other. These distinctions are applied to Roma as well by the imagery of neoliberal undeservingness, ${ }^{9}$ which prevents class solidarity among subordinated precarious populations by juxtaposing the white, deserving poor with the racialized, undeserving Roma, the latter being seen as work-shy, lazy, parasitic, over-supported, and thankless internal aliens who would not reciprocate the benefits they were given even if they could (Kóczé and Rövid 2017, 693). The 'good Roma' cluster is thus limited to the romanticized, paternalistic image of those entertaining 'Hungarians', namely musicians and more recently clothing designers and gastronomic entrepreneurs.

\section{Concluding remarks}

How can the 1993/2011 Hungarian legislative approach, conceptualizing Roma as a nationality (a national minority with, foremost, an identity politics-oriented cultural-rights framework), be characterized? Criticism is (at least) fourfold. (i) This approach and legal framework fails to comprehend the complexity of Roma-related issues, or even to comprehend the essential differences that the various policy models (minority rights, anti-discrimination, social inclusion) carry and require. (ii) This collectivist approach neglects the individual justicebased, anti-discrimination-oriented approach, and anti-discrimination and equal opportunities policies are inadequate. (iii) One can argue that Roma are used as bargaining tool for diaspora politics. (iv) It might also be argued that (at least in 1993) the entire Roma nation-building project was an essentially colonialist/ patriarchal endeavour, lacking genuine grassroots initiatives.

To further accentuate the context of this chapter, it needs to be emphasized that choices between 'ethnic' or 'national minority' conceptualizations have multi-layered political and policy implications. Positioning Roma as a historically rooted 'national minority' can be linked to and abused as a tool for 
racializing, essentializing, othering, marginalizing, and scapegoating discourses, where cultural specificities are used to explain criminality and poverty, which in turn allow for securitized policies and blatant 'correctional' segregation and paternalistic and patronizing rhetoric and policies. ${ }^{10}$ This chapter does not argue that either of the conceptualizations is right and the other is wrong, nor that a choice is inevitable or even possible in certain cases. However, and this provides the broader relevance of the Hungarian case, it shows that confusing terminology (in our case of ethnic and national minorities and nationalities) reflects and reveals a confused conceptualization and a lack of clearly defined political and policy objectives. The Hungarian case serves as a litmus test for showing that labelling does not necessarily involve form-fitted conceptualizations and that terminology does not necessarily determine policy instruments.

While the 2011 law arguably makes the legislative approach clear that Roma are foremost a national minority, this not only creates a potential for derailing public and political discussion and perception, but also raises the general question of whether not only old, historical, and traditional groups, but also all, new, immigrant, and ethno-racial communities can seek recognition as national minorities.

\section{Notes}

1 Reflecting on Oscar Lewis's concept of the 'culture of poverty' (1969), there has been a fierce debate among academics in Hungary on the applicability of the concept of the 'underclass' for Roma in Hungary and Eastern Europe (Szelényi and Ladányi 1998; Ladányi 2001; Ladányi and Szelényi 2001, 2010; Stewart 2001a, 2001b).

2 According to the Framework Convention for the Protection of National Minorities and Explanatory Report (1995, p. 12): 'It was decided to adopt a pragmatic approach, based on the recognition that at this stage, it is impossible to arrive at a definition capable of mustering general support of all Council of Europe member States.' See also: Kymlicka (2001).

3 For more, see A.L. Pap (2001, 2003).

4 See the reports of the Parliamentary Commissioner for National and Ethnic Minority Rights (Kállai 2011a, 2011b) and the report of the Parliamentary Commissioner for Fundamental Rights and of the Deputy Commissioner for the Protection of the Rights of Nationalities Living in Hungary (Szalayné Sándor and Székely 2014).

5 For an academic assessment of the 'redistribution-recognition dilemma', which are conceptualized as analytically distinct categories of justice, see Fraser (1995).

6 See, for example, a speech delivered by the Minister of Human Resources (Balogh 2014).

7 For the assessment of the decade, see Mirescu and Kóczé (2011), Jang (2015).

8 For the role of NGOs, see Kóczé (2012).

9 Note how Kóczé and Rövid (2017) cite Kymlicka (2015) offering three factors of perceived deservingness: voluntariness, i.e. whether someone's misfortune or disadvantage is under their voluntary control; identity, i.e. to what extent the person is seen as belonging to a community; attitude, i.e. the extent to which recipients are seen as accepting benefits in the spirit of civic friendship; and reciprocity, i.e. the extent to which recipients are seen as likely to help others when it is their turn to do so. 
10 Note for example how the Advisory Committee on the Framework Convention for the Protection of National Minorities Strasbourg (2016) reacted with consternation to legislation exempting certain schools from the requirements of the Equal Treatment Act allowing de facto 'benevolent segregation, or as coined by Zoltán Balog, former Calvinist priest turned minister of human resources: a "tender loving attainment process" (Rorke 2017). The Advisory Committee expressed deep concern by this development, calling it extremely worrying and that it runs diametrically contrary to principles of integration and equal treatment.

\section{References}

Additional Protocol on the Rights of Minorities to the European Convention on Human Rights, Recommendation 1201 (1993). Council of Europe.

AEB/136/2010 (2010). Available at: www.parlament.hu/biz39/aeb/info/ruszin_onk.pdf (accessed 31 December 2018).

AEB/139/2010. (2010). Available at: www.parlament.hu/biz39/ aeb/info/horvat_onk.pdf (accessed 31 December 2018).

Balogh, L. (2012a). 'Jog a kultúra örzésére - vagy ürügy a szegregációra? A roma nemzetiségi oktatás mint kétélü kard Magyarországon [The right to protect culture - or an excuse for segregation? roma minority education, a double-edge sword in Hungary]', PRO MINORITATE, Vol. 20 (Spring), pp. 207-223.

Balogh, L. (2012b). 'Minority Cultural Rights or an Excuse for Segregation? Roma Minority Education in Hungary'. In: P. Daniel (ed.), Education Policy and Equal Education Opportunities. Open Society Foundations: New York, pp. 207-222.

Balogh, L., Berki, J., Daróczi, G., Ivány, B., Koczé, A., Moldova, Z., Novoszádék, N., et al. (2013). Civil Society Monitoring Report on the Implementation of the National Roma Integration Strategy and Decade Action Plan in 2012 in Hungary, the Decade of Roma Inclusion Secretariat Foundation. Available at: www.issuelab.org/resources/15479/15479.pdf.

Balog, Z. (2014). 'A kultúrára kell építeni a felzárkóztatást [Catching up must be built on culture]', MTI-EMMI. Available at: http://romagov.kormany.hu/balog-zoltan-akulturara-kell-epiteni-a-felzarkoztatast (accessed 23 February 2019).

Barany, Z.D. (2002). The East European Gypsies: Regime Change, Marginality, and Ethnopolitics. Cambridge University Press: Cambridge, New York.

Bíró, A. (2013). 'A Debate'. In: W. Guy (ed.), From Victimhood to Citizenship - The Path of Roma Integration. Kossuth Publishing Corporation: Budapest, pp. 11-40.

Cahn, C. (2001). 'Smoke and mirrors: Roma and minority policy in Hungary'. Der Donauraum, Vol. 41, No. 3. Available at: https://doi.org/10.7767/dnrm.2001.41.3.101.

Carstocea, A. (2011). 'Ethno-business - The Manipulation of Minority Rights in Romania and Hungary'. In: T. Bhambry, C. Griffin, T. Hjelm, C. Nicholson, and O.G. Voronina (eds.), Perpetual Motion?: Transformation and Transition in Central and Eastern Europe and Russia. School of Slavonic and East European Studies: London, pp. 16-30. Case of DH and Others v. The Czech Republic (2007). Application No. 57325/00.

Case of Sejdić and Finci v. Bosnia and Herzegovina (2009). Application Nos. 27996/06 and 34836/06.

Chapman v. The United Kingdom (2001). Application No. 27238/95.

Commission for Racial Equality v. Dutton (1988). QB783.

Council of Europe \& ERICarts (2010). 'Statistics'. Available at: www.coe.int/t/dg3/ romatravellers/default_en.asp. 
Curejova, L. (2007). 'Hungary: self-abusive governance'. Transitions Online, Vol. 8, No. 22 , pp. 1-3.

Darquennes, J., Melis, A., Nelde, P.H., Salmasi, S., Tikka, M., and Weber, P.J. (2012). Euromosaic III Presence of Regional and Minority Language Groups in the New Member States. European Commission: Directorate-General for Education and Culture; Katholieke Universiteit Brussel, Brussels.

Deets, S. (2002). 'Reconsidering East European minority policy: liberal theory and European norms'. East European Politics and Societies: and Cultures, Vol. 16, No. 1, pp. $30-53$.

Dinók, H. (2012). ‘Stratégia vs. oktatásügy [Strategy vs. education politics]'. Fundamentum, Vol. 1, pp. 63-66.

Fosztó, L. (2003). 'Diaspora and nationalism: an anthropological approach to the international Romani movement'. Regio: Minorities, Politics, Society, Vol. 3, No. 1, pp. $102-120$.

Framework Convention for the Protection of National Minorities and Explanatory Report, No. H (95) 10 (1995). Council of Europe: Strasbourg.

Fraser, N. (1995). 'From redistribution to recognition? Dilemmas of justice in a "postsocialist” age'. New Left Review, Vol. 212 (July-August), pp. 68-68.

Greco-Bulgarian Communities, Advisory Opinion (1930). P.C.I.J. (ser. B) No. 17 (31 July). Available at: www.worldcourts.com/pcij/eng/decisions/1930.07.31_grecobulgarian.htm (accessed 10 February 2019).

Guglielmo, R. (2004). 'Human Rights in the Accession Process: Roma and Muslims in an Enlarging EU'. In: G.N. Toggenburg (ed.), Minority Protection and the Enlarged European Union: The Way Forward. Local Government and Public Service Reform Initiative, Budapest.

Hallam v. Cheltenham Borough Council and Others (2001). UKHL 15.

Hannum, H. (2000). 'International Law'. In: A.J. Motyl (ed.), Encyclopedia of Nationalism, First Edition. Academic Press: San Diego, pp. 405-419.

Heizler, A. (2002). 'Még nincs kisebbségi panasz [There is no minority-complaint yet]' 24 July. Available at: https://adtplus.arcanum.hu/hu/view/Nepszabadsag_2002_07/?pg $=503$ \&layout $=\mathrm{s}$ (accessed 31 December 2018).

Hungarian Central Statistical Office (2013). 'Központi Staisztikai Hivatal, A népesség anyanyelv, nemzetiség és nemek szerint [Population according to native language, nationality and gender]'. Available at: www.ksh.hu/nepszamlalas/tablak nemzetiseg (accessed 21 May 2019).

Hungarian National Social Inclusion Strategy (2011). Extreme Poverty, Child Poverty, the Roma-2011-2020.

Hungarian National Social Inclusion Strategy II (2014). The Permanently Needy - Children Living in Poor Families - The Roma; 2011-2020. Updated Version.

Hungary: Act CLXXIX/2011 on the Rights of Nationalities (2011).

Hungary: Decision No. 45/2000 (XII. 8.) (2000).

Hungary: Government Resolution No. 120/1995. (XII. 22.) (1995).

Hungary: Government Resolution No. $1093 / 1997$ (VII. 29.) (1997).

Hungary: Government Resolution No. 1048/1999 (V. 5.) (1999).

Hungary: Government Resolution No. $1186 / 2002$ (XI. 5.) (2002).

Hungary: Government Resolution No. 1021/2004 (III.18.) (2004).

Index.hu (2011). 'Megalakult a szerb és ukrán kisebbségi önkormányzat [The Serbian and the Ukrainian minority self-government was formed]'. Available at: https://index.hu/ 
belfold/2011/02/05/megalakult_a_szerb_es_ukran_kisebbsegi_onkormanyzat/ (accessed 31 December 2016).

Jang, M. (2015). 'A Roma education | Harvard Political Review'. Harvard Political Review. Available at: http://harvardpolitics.com/world/roma-education/ (accessed 20 February 2019).

Janky, B. and Kemény, I. (2003). ‘A 2003. évi cigány felmérésről [On the 2003 Gypsy survey]’. In: E. Kállai (ed.), A Magyarországi Cigány Népesség Helyzete a 21. Század Elején. MTA Etnikai-nemzeti Kisebbségkutató Intézet: Budapest, pp. 7-27.

Jeszenszky, G. (1996). 'Hungary's bilateral treaties with the neighbours and the issue of minorities'. Ethnos-Nation. Eine Europäische Zeitschrift, Vol. 4, No. 1-2, pp. 123-128.

Kállai, E. (2011a). Jelentés a Nemzeti És Etnikai Kisebbségi Általános Iskolai NevelésOktatás Helyzetéröl [Report on the Situation of National and Ethnic Minority Education in Elementary Schools]. OBH: Budapest.

Kállai, E. (2011b). Jelentés a Nemzeti És Etnikai Kisebbségi Óvodai Nevelés Helyzetéröl [Report on the Situation of National and Ethnic Minority Education in Kindergartens]. OBH: Budapest.

Kócze, A. (2012). 'Civil society, civil involvement and social inclusion of the Roma'. Roma Inclusion Working Papers. United Nations Development Programme: Bratislava.

Kóczé, A. and Rövid, M. (2017). 'Roma and the politics of double discourse in contemporary Europe'. Identities, Vol. 24, No. 6, pp. 684-700.

Kovats, M. (1996). 'The Roma and minority self-governments in Hungary'. Immigrants \& Minorities, Vol. 15, No. 1 (March), pp. 42-58.

Kymlicka, W. (2001). 'Western Political Theory and Ethnic Relations in Eastern Europe'. In: W. Kymlicka and M. Opalski (eds.), Can Liberal Pluralism Be Exported? Western Political Theory and Ethnic Relations in Eastern Europe, First Edition. Oxford University Press: New York, pp. 13-107.

Kymlicka, W. (2015). 'Solidarity in diverse societies: beyond neoliberal multiculturalism and welfare chauvinism'. Comparative Migration Studies, Vol. 3, No. 1, p. 17.

Ladányi, J. (2001). 'The Hungarian Neoliberal State, Ethnic Classification, and the Creation of a Roma Underclass'. In: R.J. Emigh and I. Szelényi (eds.), Poverty, Ethnicity, and Gender in Eastern Europe during the Market Transition. Greenwood: Westport, pp. 67-82.

Ladányi, J. and Szelényi, I. (2001). 'Van-e értelme az underclass kategória használatának? [Can the concept of underclass be used in a meaningful way?]'. Beszélö, Vol. 6, No. 11, pp. 94-98.

Ladányi, J. and Szelényi, I. (2010). ‘Adalékok a csenyétei cigányság történetéhez [Notes on the History of the Cseténye Roma]'. In: Á. Horváth, E. Landau, and J. Szalai (eds.), Cigánynak Születni. Tanulmányok, Dokumentumok, ATA - Új. Mandátum: Budapest, pp. 507-530.

Magyar Nemzet Online (2012). 'Etnobiznisz: magas az új szabályozás lakossági támogatottsága [Ethno-business: high popular support for the new law]’. Magyar Nemzet, 21 December. Available at: https://magyarnemzet.hu/archivum/belfold-archivum/ etnobiznisz-magas-az-uj-szabalyozas-lakossagi-tamogatottsaga-4108784/ (accessed 31 December 2016).

Majtényi, B. (2005). 'What has happened to our model child? The creation and evolution of the Hungarian Minority Act'. European Yearbook of Minority Issues Online, Vol. 5, No. 1, pp. 397-469.

Majtényi, B. (2007). A nemzetállam új ruhája [The Nation State's New Clothes]. Gondolat Kiadó: Budapest. 
McCrudden, C. (2005). 'Thinking about the discrimination directives'. European AntiDiscrimination Law Review, No. 1, pp. 17-23.

McVeigh, R. (2007). 'Ethnicity denial and racism: the case of the government of Ireland against Irish Travellers'. Translocations, Vol. 2, No. 1, pp. 90-133.

Mirescu, G. and Kóczé, A. (eds.) (2011). 'A Look Behind the Curtain: Reflections on the Decade of Roma Inclusion'. In: Social Inclusion and Cultural Identity of Roma Communities in South-Eastern Europe. Swisspeace: Bern, pp. 35-40.

Molnár, E. and Schaft, K.A. (2003). 'Preserving "cultural autonomy" or confronting social crisis?'. Review of Sociology of the Hungarian Sociological Association, Vol. 9, No. 1, pp. 27-42.

Nagy, J. (2010). 'Angyalok kertje'. Népszabadság: Budapest, 7 July.

National Development Agency, Hungary (2008). Ex-Post Evaluation of Roma Programmes in Hungary Financed by Phare, Budapest.

NDI, OSCE/ODIHR (2006). The Hungarian Minority Self-Government System as a Means of Increasing Romani Political Participation: National Democratic Institute Assessment Report September/October 2006, National Democratic Institute for International Affairs, Office for Democratic Institutions and Human Rights of the Organization for Security and Co-operation in Europe, pp. 1-31.

Nol.hu (2011). ‘Kakukktojások? Balhé a román kisebbségnél [Cuckoo’s eggs? Scandals at the Rumanian minority]', 9 February. Available at: http://nol.hu/belfold/kakukktojasok_balhe_a_roman_kisebbsegnel-974661 (accessed 20 February 2018).

O'Leary v. Allied Domecq [2000]. Case No CL 950275-79, Central London County Court, Goldstein HHJ.

O'Regan, M. and O'Halloran, M. (2017). 'Travellers formally recognised as an ethnic minority'. Irish Times, 1 March. Available at: www.irishtimes.com/news/politics/oireachtas/travellers-formally-recognised-as-an-ethnic-minority-1.2994309 (accessed 14 February 2019).

OHCHR (2000). Communication No 13/1998, No. CERD/C/57/D/13/1998, Office of the United Nations High Commissioner for Human Rights. Available at: www2.ohchr.org/ english/bodies/cerd/docs/A.66.18.pdf (accessed 10 February 2019).

OHCHR (2001). Miroslav Lacko v. Slovak Republic, No. CERD/C/59/D/11/1998, Office of the United Nations High Commissioner for Human Rights.

OSCE/ODIHR (2014). Parliamentary Elections 6 April 2014, OSCE/ODIHR Limited Election Observation Mission Final Report. Organization for Security and Cooperation in Europe, Office for Democratic Institutions and Human Rights, Warsaw, pp. 1-32.

Pap, A.L. (2001). 'Ethnicity and politics: definition and scope'. East Central Europe/L'Europe Du Centre-Est. Eine Wissenschaftliche Zeitschrift, Vol. 28, No. 2, pp. 41-68.

Pap, A.L. (2003). 'Ethnicization and European identity policies: window-shopping with risks'. Dialectical Anthropology, Vol. 27, No. 3-4, pp. 227-248.

Pap, A.L. (2018). Democratic Decline in Hungary: Law and Society in an Illiberal Democracy, First Edition. Routledge: Abingdon, Oxon; New York.

Pogonyi, S. (2015). 'Transborder kin-minority as symbolic resource in Hungary'. Journal on Ethnopolitics and Minority Issues in Europe, Vol. 14, No. 3, pp. 73-98.

Ram, M.H. (2014). 'Europeanization and the Roma: Spreading the Norms of Inclusion and Exclusion'. 10th Biennial Conference of the European Community Studies Association-Canada, 8-10 May, Montreal, pp. 1-30. 
Rorke, B. (2017). '10 things he really said: Zoltán Balog, Hungarian Minister for human resources'. Available at: www.errc.org/news/10-things-he-really-said-zoltan-baloghungarian-minister-for-human-resources (accessed 21 May 2019).

Sansum Molnár, J. (2017). 'Az 1993-as magyarországi kisebbségi törvény parlamenti vitája [The debate of the 1993 Hungarian minority rights Bill]'. Regio, Vol. 25, No. 3, pp. 182-202.

Stewart, M.S. (2001a). 'Spectres of Underclass'. In: J. Ladányi and R.J. Emigh (eds.), Poverty, Ethnicity, and Gender in Eastern Europe During the Market Transition. Greenwood: Westport, pp. 191-204.

Stewart, M.S. (2001b). 'Depriváció, romák és "underclass" [Deprivation, the Roma and “underclass"]'. Beszélö, Vol. 6, No. 7-8, pp. 82-94.

Szalayné Sándor, E. and Székely, L. (2014). Az Alapvető Jogok Biztosa És a Magyarországon Élö Nemzetiségek Jogainak Védelmét Ellátó Biztoshelyettes Jelentése Az AJB-3894/2012. Számú Ügyben, a Nemzetiségi Középiskolai Oktatás Helyzetéröl [Report of the Parliamentary Commissioner for Fundamental Rights and of the Deputy Commissioner for the Protection of the Rights of Nationalities Living in Hungary on Case No. AJB-3894/2012, Regarding the Situation of the Secondary Education of Nationalities]. AJBH: Budapest.

Szelényi, I. and Ladányi, J. (1998). ‘Az etnikai besorolás objektivitásáról [On the objectivity of ethnic classification]'. Kritika, Vol. 3, pp. 34-35.

Szuhay, P. (2003). 'Ez egy eredeti "cigányélet" (An authentic "Gypsy” life)'. Beszélö Online, Vol. 8, No. 5. Available at: http://beszelo.c3.hu/cikkek/\%E2\%80\%9Eez-egyeredeti-ciganyelet $\%$ E2\%80\%9D (accessed 20 February 2018).

Tajfel, H. (1981). Human Groups and Social Categories: Studies in Social Psychology, First Edition. Cambridge University Press: Cambridge, UK; New York.

Tátrai, P. (2015). 'Transformations of the ethnic structure in Hungary after the turn of the millennium'. Human Geographies - Journal of Studies and Research in Human Geography, Vol. 9, No. 1, pp. 76-96.

The Minority Rights Ombudsman (2011). Jelentés a Nemzeti És Etnikai Kisebbségi Általános Iskolai Nevelés-Oktatás Helyzetéröl, No. NEK-411/2011. Available at: www. kisebbsegiombudsman.hu/data/files/217986220.pdf (accessed 31 December 2018).

Themelis, S. (2015). 'The time of the Roma in times of crisis: where has European neoliberal capitalism failed?' '. Ethnicities, Vol. 16, No. 3, pp. 432-451.

Thornberry, P. (2001). 'An Unfinished Story of Minority Rights'. In: A.-M. Bíró and P. Kovács (eds.), Diversity in Action: Local Public Management of Multi-Ethnic Communities in Central and Eastern Europe, First Edition. Local Government and Public Service Reform Initiative, Open Soc. Inst.: Budapest, pp. 46-73.

Van Baar, H. (2011). The European Roma: Minority Representation, Memory, and the Limits of Transnational Governmentality. Universiteit van Amsterdam, available at: https://pure.uva.nl/ws/files/1164530/98879_18.pdf.

Vermeersch, P. (2003). 'EU enlargement and minority rights policies in Central Europe: explaining policy shifts in the Czech Republic, Hungary and Poland'. Journal on Ethnopolitics and Minority Issues in Europe, Vol. 1, pp. 1-33.

Vermeersch, P. (2008). 'The Roma'. In: B. Reche (ed.), Minority Rights in Central and Eastern Europe. Routledge: London, pp. 61-74.

Vermeersch, P. and Van Baar, H. (2017). 'The limits of operational representations: ways of seeing Roma beyond the recognition-redistribution paradigm'. Intersections. East European Journal of Society and Politics, Vol. 3, No. 4, pp. 120-139. 
Vizi, B. (2005). 'The EU and the Situation of Roma in Hungary in the Accession Process'. Central European Political Science Review, Vol. 6, No. 20, pp. 66-91.

Vizi, B. (2013). Európai Kaleidoszkóp. Az Európai Unió És a Kisebbségek [European Kaleidoscope. The EU and the Minorities]. L'Harmattan: Budapest. Available at: http://real.mtak.hu/10041/1/15_nemnyilv.pdf

Voiculescu, C. (2017). European Social Integration and the Roma: Questioning Neoliberal Governmentality, First Edition. Routledge.

Wrexham County Borough Council (Appellants) v. Berry (Respondent); South Bucks District Council (Appellants) v. Porter and Another (FC) (Respondents); Chichester District Council (Appellants) v. Searle and Others (Respondents) (Consolidated Appeals) (2003). UKHL 26. 


\title{
How can we understand the poor implementation of disability inclusion policy in Romania?
}

\author{
Johans Tveit Sandvin and Teodor Mircea Alexiu
}

\section{Introduction}

Since its accession to the European Union (EU) in 2007, Romania has been committed to the EU's common inclusion policies and regulations. The expectations to adapt to the EU policy go even further back, as the country was granted candidate status already in 1999. Nevertheless, in several areas there are still considerable gaps between what Romania has committed to and the actual political reality in the country. In a research project on labour-market integration of Roma and disabled people in Romania carried out between Romanian and Norwegian partners, ${ }^{1}$ we were struck by the seemingly increasing gap between officially stated policies and the realities on the ground. As the EU's inclusive policies on these areas have gradually been incorporated into national politics, while very little seems to have changed on the ground, the gap between politics and reality has become increasingly noticeable (Dinu, 2014). In this chapter, we will concentrate on the area of disability inclusion. We do not present an empirical analysis; instead, the chapter discusses the situation in Romania as it appears through publicly available information and through empirical studies that have been published elsewhere by ourselves and by others.

The implementation of EU disability policy in Romania has been slow. The latest European Semester Country Report on disability provided by ANED $^{2}$ (2018) states:

During 2016 and 2017, Romania has moved into a new stage concerning the approach towards inclusion of people with disabilities in the spirit of the CRPD, which was ratified in 2011. [...] However, when it comes to the actual indicators on the situation in Romania, things are still precarious for people with disabilities.

In the next section, we will explain more about how precarious the situation is. We are fully aware that the gap between official disability politics and practical realities is large in most countries, but the gap is particularly large in some of the 
Central and Eastern European (CEE) EU member states. The aim of this chapter is to discuss possible explanations for this gap with respect to Romania.

The implementation of public policy should not be seen as a straightforward, linear, and rational process, although political debates often create such an impression. Studies of attempts to realize political intentions or reforms have documented that there are most often great discrepancies between intentions and results in public policy (Brynard, 2005; Weaver, 2009), and also with respect to disability (Keiser, 2001). Emphasis has been placed on the conditions of political governance (Rose-Ackerman, 2004; Ali, 2006) such as contradictions within policy design, structures and roles, insufficient performance regulation, weak accountability, or weak capacity of actors to coordinate their activities (Wild et al., 2012). In our Romanian case, the implementation process is particularly complex in that supranational political intentions must first be interpreted and translated into national politics before they can be implemented, and this is also referred to as multi-level governance (Cerna, 2013). Furthermore, EU policies can sometimes appear inconsistent because country-specific recommendations in relation to one field might conflict with recommendations in other fields. Still, we believe that the overall aims of the EU disability policy, as it is designed today within the framework of the United Nations Convention of the Rights of People with Disabilities (UNCRPD), provides a fairly clear direction. It is on this basis that the large gap between the EU disability policies and the practical realities on the ground in Romania appears as an interesting puzzle to explore.

It is reasonable to assume that the existing disability equality gaps in Romania are somehow related to the country's political heritage. The so-called transition countries face particular challenges compared to the Western European countries, both economically and politically. It is claimed that disabled people, who were to a large extent confined and marginalized in institutions and special schools under state communism, suffered a worsening of their living conditions during the transition era due to financial difficulties in maintaining the healthcare system and the residential institutions (Mussida and Sciulli, 2016; Mladenov, 2017). Moreover, restoring existing structures would not comply with EU policies, which require a quite different institutional and regulatory framework. It is therefore a question of whether this is just about time and resources, or whether there are other obstacles to the realization of a more inclusive disability policy in Romania.

\section{The situation for disabled people in Romania}

The life situation for disabled people in Romania is difficult, and the material conditions are poor. The risk of household poverty is generally high in Romania compared to the EU average, and disabled people are particularly exposed to poverty (ANED, 2018). Disability benefits are low - an average of 1,200 euros per year - which is low even compared to other CEE countries (Mussida and Sciulli, 2016). The safest way to avoid poverty is through gainful employment, 
but access to the open labour market is very difficult. The real employment rate among disabled people in Romania is difficult to estimate, but according to the European Semester 2017/2018 Country Report on disability, the official disability employment rate in Romania is 15.5 per cent, but that also includes people working in protected units (ANED, 2018, p. 11). The National Authority for Persons with Disabilities reports for September 2017 a total of 751 protected units (ibid., p. 13). In addition, 'people with disabilities have a working standard of five hours per week (out of 40 possible), meaning one hour a day' (ibid., pp. 13-14). Baciu and Lazar (2017, p. 7) also confirm that 'the Romanian persons with disabilities have an extremely low level of inclusion on the labour market, which, according to the cited reports, varies between $5 \%[\ldots]$ and $12.7 \%[\ldots]$ from the total number of persons with disabilities'. In addition, a comparative study including Poland, Lithuania, Romania, the Czech Republic, the Slovak Republic, and Hungary found that Romania has by far the lowest disability employment rate among the countries in question (Mussida and Sciulli, 2016).

Some legal steps have been taken with the aim of motivating employers to hire disabled people. According to Law 448/2006 (Article 78-2) on the 'Protection and Promotion of the Rights of Persons with a Handicap', any employers (public or private) with 50 employees or more are obliged to employ disabled people corresponding to at least 4 per cent of the staff. Unfortunately, there are no official data available regarding the number of persons employed through this scheme, but it is believed to be few due to certain loopholes in the system (Alexiu et al., 2015a). For example, employers failing to fulfil this obligation can choose between paying a monthly fee amounting to 50 per cent of the minimum average salary for each position they were supposed to employ and buying products or services from protected units for the same amount.

Also, as Baciu and Lazar (2017, p. 13) describe, in Romania:

A person can be employed only if he/she holds a medical certificate which ascertains the person is able to carry the type of activity he/she is hired for. Moreover, the main law that regulates work relations (The Labor Code Law no. 53 from 2003) clearly stipulates that if such a certificate is not issued, the work contract is void (article 27, paragraph 2).

What is particularly worrisome, according to Baciu and Lazar, is that the Romanian legislation motivates this practice as a response to the EU 'Framework Directive' on the introduction of measures to encourage improvements in the safety and health of workers at work. So, instead of facilitating the safety and health of workers at work, this selection based on medical judgements, which is actually a protection for employers, 'is promoted, under this law, as a "protective measure" for the employee' (ibid., p. 14).

One reason for the low participation on the labour market is lack of education and training. Disabled people in Romania have low participation in education at all levels. According to the ANED country report, in 2015 only 57 per cent of 
children registered as disabled were enrolled in any form of education (ANED, 2018). Furthermore, for those who did enrol, data from the 'County School Inspectorate' indicated that 62.3 per cent attended special schools (ibid.). In the Country report on non-discrimination for Romania, the European network of legal experts in gender equality and non-discrimination, states:

In spite of the adoption by the Ministry of Education of three different sets of regulations regarding desegregation in education, the failure to follow up and to establish a functional implementation mechanism has led to further cases of segregation being reported.

(European Commission, 2018)

In our study (see Alexiu et al., 2015a), some of the disabled interviewees described how they were denied access to the regular primary school, even though (mandatory) assessments had shown that they were fully capable of utilizing mainstream education. With regard to secondary education, some even told about difficulties in getting access to special schools. Those who had some level of higher education all told about difficulties in getting access to college or university or in getting the assistance they needed to be able to study on equal footing with their peers. It seemed as if disabled people were regarded as unfit for proper education, despite the fact that education is probably the most significant means to employment and hence to an independent life (ibid., p. 69).

Regarding accessibility, few public buildings are fully accessible to disabled people (Romanian Government, 2005). Also, except for a very small number of sign-language interpreters, Braille printing technologies, and audio recording techniques, there are no services or technologies to ensure access to information and communication for people with sensory impairments (Alexiu et al., 2014, p. 42).

Romania does have an Anti-discrimination Law, adopted in 2000. However, there is no definition of disability in the Anti-discrimination Law, and the National Council for Combating Discrimination (NCCD) uses a rather out-dated definition in its cases, provided by the special legislation on the rights of persons with disabilities (Law 448/2006 and subsequent legislation). ${ }^{3}$ Despite many serious weaknesses in the law, in 2017 the NCCD received 652 petitions, out of which 74 concerned disability. The report does not say how many of these were brought before the administrative courts or how many were decided in favour of the NCCD.

Despite weaknesses both in the law itself and in the mechanisms for its enforcement, the NCCD does play an important role in making discrimination visible, sometimes even by stretching the law. Although the law does not provide explicitly for disability as a protected ground in relation to housing, the Country report on non-discrimination tells about a case in which the NCCD, in an ex officio investigation against the institution of the Mayor of Bucharest and the General Council of Bucharest Municipality, concluded that their social housing 
criteria were discriminatory. It turned out that certain groups were ranked, with points, by how much they were considered to deserve the grant for social housing. Persons with disabilities were provided 4 points 'as compared to 10 points for persons with higher education and 15 points for veterans and war widows, revolutionaries and former political detainees, leading to de facto exclusion of persons with disabilities' (European Commission, 2018, p. 92). This in itself is illustrative of the situation in Romania that such practices actually exist.

In summary, disabled people in Romania live under quite difficult conditions. The situation is characterized by a high degree of exclusion and segregation in relation to education, work, and society at large, and disabled people are highly exposed to poverty and marginalization. Although antidiscrimination legislation is in place, it contains several weaknesses, and enforcement has so far been weak.

\section{The implementation of EU policies and regulations}

The situation described above is in stark contrast to the expectations the EU has for its member countries. The EU promotes active inclusion and full participation of disabled people in society, in line with the EU human rights approach to disability issues (EPRS, 2018). The European Disability Strategy 2010-2020: A Renewed Commitment to a Barrier-Free Europe, says 'EU and its Member States have a strong mandate to improve the social and economic situation of people with disabilities' (European Commission, 2010). The Strategy refers to The Treaty on the Functioning of the EU (TFEU), which requires the European Union to combat discrimination based on disability when defining and implementing its policies and activities (Article 10) and gives it the power to adopt legislation to address such discrimination (Article 19). The strategy also refers to the UNCRPD: 'the first legally-binding international human rights instrument to which the EU and its Member States are parties. [...] The UN Convention requires States Parties to protect and safeguard all human rights and fundamental freedoms of persons with disabilities' (ibid.). The European Disability Strategy 2010-2020 builds on the UNCRDP.

With regard to Romania's follow-up of these obligations, the country report on non-discrimination states:

Though it signed the UN Convention on the Rights of Persons with Disabilities in September 2007, Romania only ratified it in November 2010. No subsequent legislation for harmonisation has been adopted. Romanian legislation still uses the concept 'handicap' instead of 'person with disability', promoting a medically focused approach.

(European Commission, 2018, p. 6)

It also says that the Romanian translation of the convention includes 'major errors on key concepts' (ibid., p. 35). 
Still, in September 2016, the Romanian Government adopted the new National Strategy called A Society without Barriers for People with Disabilities 2016-2020 and a corresponding National Action Plan. The adoption of these policy instruments, which had been postponed for several years (ANED, 2018), created a certain optimism. However, there is a very large gap to fill if one is to meet the goals of the Strategy. The ANED country report says, 'These gaps were strongly acknowledged in the 2017 European Semester process but there is a need for evidence of clear and well implemented policy measures to address them in 2018' (ANED, 2018).

In 2016, the Parliament also adopted Law 8 on the establishment of the monitoring mechanisms provided by the Convention (Article 33(2) of the UNCRPD). However, only three months after being appointed, the President for the Monitoring Council filed a request to leave the post. According to the Country report on non-discrimination, the reasons for leaving the post were:

obstacles in the communication with Government representatives, performing work for three months without remuneration, the lack of appropriate headquarters and difficulties in identifying accessible headquarters and the lack of specialist staff for the finalization of administrative papers necessary for the legal establishment of the Monitoring Council. There are no reports on the effectiveness of the Monitoring Council or suggesting any coordination with the NCCD so far.

(European Commission, 2018, p. 120)

This creates poor odds for an effective implementation of the National Strategy and Action Plan.

What we have tried to show so far is that disabled people in Romania live in difficult conditions, perhaps among the most difficult conditions in Europe. The EU has ambitious goals for its disability policy, which Romania as an EU member is committed to, but there appear to be major obstacles to the fulfilment of these commitments. Collins and Coughlan (2016, p. 5) state, 'Although Romania ratified the UN Convention (CRPD) in 2011, it is difficult to measure the impact it has had, if any, on support for families caring for a child with a disability.' They also quote a mother of a disabled child, saying: 'There is a special law number 448 that states all the rights of people with handicaps. But we are a lot behind the EU community, because this law is not applied' (ibid., p. 9). So, why is it not applied? What are the main obstacles to a more effective implementation of the national and EU policies and regulations concerning disability?

\section{Comprehending the gap}

\section{Maintaining a medicalized approach}

There is probably no single answer to the questions raised above. It is most likely a combination of historical, cultural, and political factors that is impeding 
the implementation of an inclusive disability policy in Romania. Parts of the answer are probably to be found in certain culturally rooted beliefs about and attitudes towards disability as a phenomenon. Disability in Romania is predominantly understood as a medical term - an abnormality of the body - and the medical system serves as the guardian of normalcy, as already shown to be the case in relation to employment. As Baciu and Lazar (2017, p. 11) put it, 'It appears obvious that, currently, Romanian policies lack a centralized vision on the conceptualization of disability and struggle in conciliating the global trend (based on the social model) with the local practice (heavily influenced by the medical model).' Disability is linked to a complex medicalized and bureaucratic system of disability assessment and classification. The system, which was established under communism, has been pretty much kept intact since 2011 under the direction of the National Authority of Disabled Persons.

Neither the legacy nor its segmentation is unique to Romania. According to Mladenov (2017):

Many state socialist countries created centralized systems for disability assessment that rendered disability exclusively in terms of inability to work due to medically certified individual 'deficiencies'. [...] Disabled people seeking social support were required to attend medical commissions comprising physicians who evaluated the claimant's capacity to engage in wage labour on the basis of purely medical criteria.

(Ibid., p. 110)

Furthermore, he says:

The medical-productivist system of classifying and assessing disability has proven to be as resistant to change after 1989 as segregated service provision. The system survived almost intact the demise of state socialism and has continued to dominate disability policy in a number of post-socialist countries.

(Ibid.)

The bureaucratic and medicalized character of the system is also vividly described by those who depend on it. Collins and Coughlan (2016), referring to mothers interviewed about the experiences of being told that their child had a disability, tell that 'the process was made more difficult by the attitudes of professionals they met at the Commission and the distress felt by the mother and child by physically having to present themselves annually at the Commission' (ibid., p. 11). The authors advocate challenging 'the prevailing medically oriented "disability as tragedy" model, which is currently evidenced within areas of the Romanian healthcare system' (ibid., p. 12).

Also, many interviewees in our study complained about the rigidity and the degrading attitudes they experienced when encountering the Commission. A 
young woman told that she for a long time did not have a certificate. She did not have the time to go to the city where the Commission was located to stand in line and then be told to come back the day after with some other document. She finally managed to obtain the certificate, but she had to travel several times to the city for it (Alexiu et al., 2015a, p. 19). Another woman told how the doctor at the Commission would not believe her at first. He thought she was just pretending, and she was subjected to a rather degrading examination before it was established that she was eligible for the certificate (ibid.). Baciu and Lazar (2017, p. 12) say:

The accounts of the disabled informants about the experience with the assessment and the attitude of the staff involved in the process are vivid, presenting the story of a staff that has rather an authoritarian and patriarchal attitude towards their beneficiaries, treating them with superiority and suspicion, instead of taking the responsibility of informing and counselling them about their rights.

It seems like the medicalized system, with roots back to the communist era, has worked to maintain a contempt in Romania for everything that is perceived as abnormal in the body, or the 'undesired differentness' as Goffman (1963) calls it. In her doctoral study on social perceptions of disability in Romania, Stamatin (2010) shows that negative attitudes towards disabled people are both profound and widespread among the general population. This reveals a disablism, which, like sexism and racism, 'expresses itself in exclusionary and oppressive practices at a wide range of levels: interpersonal, institutional, cultural, and societal' (Barnes and Mercer, 2003). It is likely that such 'predominant cultural attitudes' not only uphold, but also 'disguise direct and indirect forms of discrimination' (Alexiu et al., 2015a, p. 59).

\section{Cultural lag}

There is hardly any doubt that the attitudes and practices described above constitute an obstacle to the implementation of a more inclusive disability policy. At the same time, there are reasons to believe that a more persistent implementation of such policies would have had an impact on the prevailing attitudes and practices. Therefore, the question remains as to why so little has been done since accession to the EU, both in terms of incorporating EU disability policy into the national policy and legislation and in terms of implementing policies already in place.

Some indications suggest that certain developments might be underway. National disability policies are gradually becoming more in compliance with EU policies (ANED, 2018), although questions are being raised about clear policy measures for their implementation. It is also suggested that media representations of disabled people are generally more positive than they used to be (Ciot 
and Van Hove, 2010). However, the development is slow and there is no great impatience associated with the issue. The question is how to make sense of this seeming lack of energy in the design and enforcement of an inclusive disability policy in Romania.

One explanation could be that it represents a kind of cultural lag. The term was coined by sociologist William F. Ogburn (1922) in his work on social change, and it refers to the notion that non-material culture needs time to catch up with technological or material changes in society. According to Ogburn, cultural lag occurs because material culture tends to evolve and change rapidly, while non-material culture is more reluctant to change. New technology is often imposed from outside and is likely to challenge established practices and associated culture. Could the same apply to new policies imposed from outside without a root in existing practices and culture?

The idea is alluring because it indicates that it is just a matter of time before attitudes and practices adapt to prevailing international policies, even though the idea suggests that adaptation might take a slightly different path than intended in order to merge with other parts of culture. The question, however, is whether it is reasonable to perceive social change simply as a passive, albeit reluctant, adaptation to external pressure. First, one needs to explain what creates the external pressure. Second, adaptation is not always passive, and resistance does not necessarily express a backward unwillingness to change.

Sometimes the resistance is directed not so much towards the imposed changes as towards the power to impose - the hegemony that allows someone to universalize their own cultural values. According to Ghai (2001, p. 93), the discourse of disability activism in India constitutes 'a meta-narrative that universalizes disability'. She contends that the leaders of the movement are middle-class urban men from an elite background and that their fight for disability rights and independent living is borrowed from their Western counterparts. Such values, she argues, while perfectly appropriate in some contexts, become universal solutions that ignore the specifics of other contexts:

Whereas the West can focus on male-centric concepts of autonomous and independent individuals without any notion of collective responsibility, Indian society is not in the position to do so, not only because of a lack of resources and insight, but also because of the cultural construction of social realities along patriarchal lines.

(Ibid., pp. 93-94)

Along the same lines, we can ask if the conception of disability underpinning the EU disability policy is fully applicable in Romania today. This is not to criticize the theories and conceptions of disability developed in a Western context, but rather to question their immediate and universal applicability. For example, are the structural conditions for a realistic implementation of EU disability-inclusive policies present in Romania today? If not, the resistance is not necessarily 
directed only towards the policies as such, but also towards the conditions for their implementation.

\section{The historical legacy}

The state welfare arrangements in Romania have remained very much the same since the abolishment of the communist regime in 1989, particularly so with respect to disability. As we have seen, disability is predominantly a medical term, denoting deficiency and incapability. Being classified as disabled not only qualifies one for disability benefits, but might also disqualify one for ordinary education or work. Being able to go to ordinary schools, to enter university, or to get a job on the ordinary labour market requires another certificate saying one is fit. Some of our interviewees tell that they struggled for years for such certificates (Alexiu et al., 2015a). The general attitude in Romania is that disabled people are not normal and therefore do not belong in normal settings such as regular schools, higher education, or the labour market. The problem lies solely with the individual and needs to be corrected in order to qualify for ordinary education or work.

This perception of disability is a state socialist legacy, which, according to Mladenov (2017, p. 104), 'is still conditioning the understanding of disability and guiding disability policy in postsocialist countries'. It is a state socialist legacy in the sense that it was the prevailing perception under state socialism, but it also preceded state socialism. The degrading medical perception is a legacy also of the medical and eugenic thinking that prevailed in the whole of Europe and beyond in the early decades of the twentieth century. Even though eugenic ideas became somewhat discredited during World War II, the basic thinking about disability as " "flawed" minds and bodies' (Barnes and Mercer, 2003 , p. 1) remained much the same throughout most of the twentieth century. During the 1960s, however, the common-sense conception of disability was contested in the West, first by disabled people themselves. An emerging disability movement managed to turn public attention also towards the environment. The 'problem of disability', as Hunt (1966) expressed it, 'lies not only in the impairment, but also, more importantly, in the area of our relationship with "normal" people' (in Barnes and Mercer, 2003, p. 9). This happened not only in Britain and the US, as some biographers might want us to believe, but across most Western countries and probably also elsewhere. In Norway, the 1968 annual meeting of the National Association of the Disabled gave rise to the following story in the main national newspaper: 'Like a storm the [association] has come rushing in on the societal scene during the last years, led by new leaders from a new generation, rooted in a new time, with new ideas and new ways of thinking.' The newspaper also referred to the following question raised at the meeting: 'Shouldn't the society be built in such a way as to suit all those who are to live in it?' (Arbeiderbladet, in Froestad and Ravneberg, 1991, p. 304, our translation). This is probably something that disabled people have thought about and 
even articulated long before this time. What was new in the 1960s and onward was a political climate that allowed for it to be expressed in public, loudly, and even to be heard.

This was a collective fight for collective rights and for dignity and respect. It was a fight that gradually paid off, albeit slowly, at the national as well as EU level. Considering the EU, or EEC as it was from its start in 1957, the first document that had any direct relevance for disabled people is from 1974, regarding a 'Community action plan for the vocational rehabilitation of handicapped persons' (Waldschmidt, 2009). The EU policy continued to focus on vocational rehabilitation, if anything at all, until the late 1980s when the focus shifted more towards labour market integration. Only from around the turn of the millennium, on the background of the Amsterdam Treaty (1995), was there a new orientation in European disability policy, emphasizing anti-discrimination and equal rights. The policies that Romania and other CEE countries are expected to implement, promptly, are thus the outcome of half a century of gradual development, launched and enforced by a collective disability movement.

It is difficult to overestimate the political significance of the disability movement, which at the time it was at its strongest was more or less completely unknown to the communist countries. Mladenov (2017, p. 112) says, with reference to Phillips (2009), '[I]t was not until the late 1980s and early 1990s that disability rights activists in the (former) Soviet Union were able to tap into international advocacy discourse and rights movements', which was probably no less true for other state socialist European countries. Also, according to Mladenov, while the post-socialist 'transition' restored party pluralism and representative democracy, civil society, including disability organizations, remained weak (ibid.). It is also important to note that many of the core values and principles currently being imposed on the CEE EU member states are just about to become part of mainstream policies and discourse in Western countries. One should not expect these policies to be easily transferable to a context that has had no interference with its generating forces.

\section{Opposition}

What has been said so far might create the impression that obstacles to the implementation of the EU disability policies are solely due to antiquated conceptions of and attitudes towards disability and disabled people. However, the reluctance to adapt to EU policy and regulations goes far beyond the disability inclusion policies. Hunya (2017) claims that Romania's accession to the EU was premature and that, despite a demonstrated willingness to adapt to the EU regulations prior to the accession, there has been a 'slowdown of the pace of reforms in the post-accession period' (ibid., p. 6). Vasile Puscas, who supervised Romania's negotiations prior to its accession in 2007, says no Romanian governments have been very committed to implementing EU policies, and that: 'Successive governments, not a specific government, both conservatives and social democrats, 
followed the same pattern of EU policy inside the country' (EURACTIV, 2018 ${ }^{4}$ ). This suggests the need for a broader explanation for the poor implementation of the EU disability policy as a supplement to those already discussed. Could it be that Romania is generally reluctant to comply with EU policies and regulations? If so, is this due to EU's superior position and to the fact that Romania has long experience of being subject to supremacy?

It is important to note that the legacy of the national territory that eventually would become the Romanian nation state is fragmented, to put it mildly. The territory has been subjected to a number of colonial powers, such as the Persians, the Romans, the Goths, the Huns, and the Avars (in that order), before the territory in 700 became part of Bulgaria. In the late Middle Ages, large parts of today's Romania came under Ottoman rule, and later, from around 1700, were subject to the Habsburg Empire. Parts of the area were later conquered by Hungary, Austria, and Russia. Only in 1866 was Romania recognized as an independent empire, although parts of the country were still under the rule of Austria-Hungary (Transilvania) and Russia (Bessarabia). Romania received its current borders only in 1944. At that time, however, the country was for all practical purposes occupied by the Soviet Union, who, as an ally, had passed through Romania on its way to Germany, and, through pressure, managed to transform the country into a Communist People's Republic, which it remained until 1989. Prior to this, with the exception of two decades in the Middle War, when Romania was a relatively liberal constitutional monarchy, Romanians had always been subject to either colonial powers or internal dictatorships.

This might explain why Romania, unlike many of the other CEE countries, lacked an organized opposition to the communist regime that could take responsibility for the transition to a new liberal democracy. Ion Iliescu, who was president from 1989 to 1996, was a former communist who 'tried an in-between approach in the first years of the transition and failed' (Mungiu-Pippidi, 2006, p. 27). Also, Prime Minister Nicolae Vacaroiu (1992-1996) was very reluctant to pursue economic reforms (Gallagher, 2005, p. 114). The fact that Iliescu was later re-elected as president (2000-2004) shows the ambivalence of the population. As late as 1999, two-thirds of Romanians still thought that communism had been a good idea but was badly put into practice, and according to MungiuPippidi (2006), 'Support for post-communist parties throughout the transition remained higher than support for challenger parties' (ibid., p. 25).

The ambivalent attitude towards the aftermath of communism depended partly on the fact that living conditions declined in the early years after the fall of communism. Nevertheless, it also reflected a basic scepticism in large parts of the population about foreign ideas and values and an orientation towards what were perceived as traditional Romanian values, in the search for a 'true identity' (Alexiu, et al., 2015b). It is therefore perhaps not surprising that Romania is a bit wary of again having to submit to a new supranational regime. Like many of the CEE countries, becoming an EU member gave access to economic resources, which was gravely needed for a depleted post-communist economy, but escaping 
one supranational regime just to submit to another was perhaps not what most people were longing for.

Postcolonial theory offers a critical perspective on the cultural consequences of European colonization, consequences that have remained even long after the colonized countries regained their freedom. Although primarily concerned with Western European colonialization, Korek (2009, first paragraph) argues that: 'We can look in a similar way at the modern history of Central and Eastern Europe, at the recently fallen Soviet Empire, and research the imperialist discourses of the "West" on the subject of the European "East" .

Western Europe has great power, not only economically, but also because of its political and normative position in the world. Western Europe, and the EU in particular, has become an ideological and moral superpower as the protector and manager of the UN conventions and the location of the majority of global humanitarian organizations. The position of Western Europe in this respect is seldom debated, which has led to what some have termed Eurocentrism (Amin and More, 1989). A feature of Eurocentrism is the tendency to regard European values and principles as universal and as the benchmark for the evaluation of others. As Lindelöf (2001, in Korek, 2009) puts it:

In the 'West' - both in the street and in the university - Eastern Europeans are commonly treated as somewhat old-fashioned, backward and not modern, as 'not yet' people, to borrow an accurate term from John Stuart Mill. After the fall of Communism, Eastern European countries should 'catch up' with the West, both economically and politically and socially and culturally; 'they' should join the European Union and NATO and become normal people - in other words, like 'us'.

(Lindelöf, 2001, p. 15)

Hence, CEE countries are regarded as European countries in the making. To perceive this from a postcolonial perspective is to acknowledge the realities of power and of hierarchy. In this perspective, Romania is not only committed to EU's policy and regulations, but is also subordinated to a cultural and moral supremacy. There is every reason to believe that this is something felt, albeit not necessarily in a conscious way, and that it creates a certain resistance towards obediently submitting to the EU's values, policies, and control. Hunya (2017, p. 14) claims: '[E]ven if not outspokenly, Romania's policy has never gone beyond nationalist self-interest. Even the undercurrent of EU-scepticism comes to the surface time to time in the form of demonstration of national pride and refusal of international control mechanisms.'

\section{Conclusion}

The aim of this chapter was to explore possible explanations for the poor implementation of EU disability policies in Romania. As a member of the EU, 
Romania is committed to EU policies and regulations, including with respect to a rather ambitious, inclusive, and rights-based disability policy. However, as we have tried to show, Romania is far from fulfilling their obligations in this respect. On the contrary, huge gaps exist between adopted policies and regulations and the actual situation on the ground. This chapter discusses possible obstacles to a more effective policy implementation.

Among the obstacles discussed is an overly bureaucratic and medicalized system of assessment and support that is characterized by authoritarian and patriarchal attitudes. With reference to the term cultural lag, it is suggested that the prevailing cultural attitudes in Romania do not (yet) constitute favourable conditions for the implementation of inclusive policies. However, the notion of cultural lag indicates that it is just a matter of time before the culture adapts to mainstream (Western) European values, hence being synchronized with the policies that the country has committed to. We have argued that this is somewhat simplified.

Both the medicalized system and the aligned culture are legacies of state socialism. However, we have argued that these precede state socialism and can be traced all the way back to the medical and eugenic thinking dominating the whole of Europe in the early decades of the twentieth century. While this thinking was challenged starting in the 1960s by a growing and increasingly selfconfident disability movement, the state socialist countries were cut off from this influence. After the collapse of state socialism, civil society remained weak, including disability organizations. This allowed the medical and patriarchal perception to maintain hegemony, which in turn impeded the introduction and implementation of new and more inclusive policies.

We have also seen that the reluctance to submit to the EU's policies and regulations is not limited to disability, and it seems that Romania might be generally reluctant to submit to EU supremacy (Hunya, 2017). This might be due to previous experiences of subordination, most notably in relation to the Soviet empire, but also in relation to a series of other empires throughout history. Even Western Europe works and acts as a supremacy - a moral superpower tending to universalize its own values, leaving Central and Eastern Europe to a kind of moral outskirt. It should not be a surprise, therefore, that Romania is hesitant to submit to yet another supremacy. Moreover, it helps to shed light on the poor implementation of the EU disability policy in Romania.

However, merely understanding the reluctance to bow to EU supremacy and policy demands does not help disabled people in Romania. Without substantial policy improvement, their situation will remain precarious. What the discussion above indicates, however, is that moral indignation on the part of the EU is perhaps not what will give momentum to making improvements. A stronger and more whole-hearted effort on the part of Romania to comply with the EU disability inclusion policies might require a different communication that not only aims at balancing the feeling of subordination, but which also aims to convince more than to persuade regarding the supremacy of the values on which the EU disability policies are based. 


\section{Notes}

1 The study was carried out in cooperation between West University Timisoara, Romania, and Nord University in Norway, funded by the EEA financial mechanism (2014-2016). The study included qualitative interviews with disabled people $(\mathrm{N}=25)$ and a wide spectrum of public and private service workers and representatives of different authorities $(\mathrm{N}=40)$ about their experiences and perceptions regarding disability policies and practices, particularly with respect to education and access to the labour market.

2 Academic Network of European Disability Experts.

3 Law 448/2006 defines disabled persons as "those persons who, due to a physical, mental, or sensorial affection, do not have the abilities for performing day-to-day activities, requiring protective measures in support of their social recovery, integration, and inclusion' (European Commission, 2018, p. 52).

4 www.euractiv.com/section/enlargement/news/architect-of-romanias-eu-bid-saysdecade-of-membership-was-mishandled/.

\section{References}

Alexiu, T.M., Bîrneanu, A.G., Baciu, E.L., Sandvin, J.T., Fylling, I., Breimo, J.P., Lazár, T.A., Dincá, M., and Ungureanu, R. (2014). The Labor Market Integration of People with Disabilities In Europe and Romania: Literature and Policy Review Report. Timisoara: West University of Timisoara.

Alexiu, T.M., Baciu, E.L., Bîrneanu, A.G., Sandvin, J.T., Fylling, I., Breimo, J.P., Lazár, T.A., Dincá, M., and Ungureanu, R. (2015a). Mapping the Hindrances and Barriers to Employment as Experienced by Vulnerable Populations. Timisoara: West University of Timisoara.

Alexiu, T.M., Baciu, E.L., Sandvin, J.T., Fylling, I., Breimo, J.P., Bîrneanu, A.G., Lazár, T.A., Dincá, M., and Zamfirescu, I. (2015b). Final Report on the Institutional Ethnography of Labour Market Integration of Vulnerable Populations (Disabled Individuals), Discussed in Relation to European and National Policy and Research. Timisoara: West University of Timisoara.

Ali, S. (2006). Why does policy fail? Understanding the problems of policy implementation in Pakistan - a neuro-cognitive perspective. International Studies in Educational Administration, Vol. 34(1).

Amin, S. and More, R. (1989). Eurocentrism. New York: NYU Press.

ANED (2018). European Semester 2017/2018 country fiche on disability, Romania.

Baciu, E.L. and Lazar, T.A. (2017). Between equality and discrimination: disabled persons in Romania. Transylvanian Review of Administrative Sciences, No. 51 E/2017, pp. 5-19.

Barnes, C. and Mercer, G. (2003). Disability (Key Concepts). Oxford: Polity.

Brynard, P. (2005). Policy implementation: lessons for service delivery. Journal of Public Administration, Vol. 40, Special Issue 3, pp. 649-664.

Cerna, L. (2013). The Nature of Policy Change and Implementation: A Review of Different Theoretical Approaches. Brussels: OECD.

Ciot, M.-G. and Van Hove, G. (2010). Romanian approach to media portrayals of disability, Disability \& Society, Vol. 25(5), pp. 525-538.

Collins, T. and Coughlan, B. (2016). Experiences of mothers in Romania after hearing from medical professionals that their child has a disability. Journal of Policy and Practice in Intellectual Disabilities, Vol. 13(1), pp. 4-14. 
Dinu, A. (2014). Rights of children with disabilities in post-communist Romania. Righting Wrongs. A Journal of Human Rights, Vol. 4(1). http://blogs.webster.edu/humanrights/files/Dinu_Children-in-Romania.pdf

EPRS (2018). EU policies for persons with disabilities. Topcal Digest, European Parlamentary Research Service. www.europarl.europa.eu/EPRS/TD_Persons_with_disability.pdf.

EURACTIV (2018). www.euractiv.com/section/enlargement/news/architect-of-romaniaseu-bid-says-decade-of-membership-was-mishandled/.

European Commission (2010). The European Disability Strategy 2010-2020: A Renewed Commitment to a Barrier-Free Europe.

European Commission (2018). Country Report, Non-Discrimination, Romania. European network of legal experts in gender equality and non-discrimination.

Froestad, J. and Ravneberg, B. (1991). Fra veldedighet til rettferdighet. Historien om Norges Handikapforbund (From Charity to Justice. The History of the Norwegian Association of the Disabled). Oslo: Norges Handikapforbund.

Gallagher, T. (2005). Theft of a Nation. Romania since Communism. London: Hurst \& Co.

Ghai, A. (2001). Marginalization and Disability: Experiences from the Third World. In: M. Priestley (ed.), Disability and the Life Course. Global Perspectives. Cambridge, UK: Cambridge University Press.

Goffman, E. (1963). Stigma. Notes on the Management of Spoiled Identity. Harmondsworth: Penguin.

Hunt, P. (1966). A Critical Condition. In: P. Hunt (ed.), Stigma: The Experiences of Disability. London: Geoffrey Chapman.

Hunya, G. (2017). Romania: ten years of EU membership. Romanian Journal of European Affairs, Vol. 17(1), pp. 5-15.

Keiser, L.R. (2001). Street-level bureaucrats, administrative power and the manipulation of federal social security disability programs. State Politics and Policy Quarterly Vol. 1(2), pp. 144-164.

Korek, J. (2009). Central and Eastern Europe from a Postcolonial Perspective. Postcolonial Europe. www.postcolonial-europe.eu/essays/60-central-and-eastern-europefrom-a-postcolonial-perspective.html.

Lindelöf, K.S. (2001). Polen i postkolonialt perspektiv (Poland in a postcolonial perspective). In: Nätverket, No. 10. http://publications.uu.se/journals/1651-0593/natvarket.htm.

Mladenov, T. (2017). Postsocialist disability matrix. Scandinavian Journal of Disability Research, Vol. 19(2), pp. 104-117.

Mungiu-Pippidi, A. (2006). Europeanisation without Decommunization: A Case of Elite Conversion. In: D. Phinnemore (ed.), The EU \& Romania. Accession and Beyond. Federal Trust for Education and Research, pp. 17-28.

Mussida, C. and Sciulli, D. (2016). Disability and employment across Central and Eastern European Countries. IZA Journal of Labor \& Development, Vol. 5(1), pp. 1-24.

Ogburn, W.F. (1922). Social Change with Respect to Culture and Original Nature. New York: B.W. Huebsch.

Phillips, S.D. (2009). There are no invalids in the USSR!: A missing Soviet chapter in the new disability history. Disability Studies Quarterly, Vol. 29(3), n.p.

Rose-Ackerman, S. (2004). The Challenge of Poor Governance and Corruption, Copenhagen Consensus Challenge Paper. In: Lomberg, B. (ed.), Global Crises, Global Solutions. Cambridge, UK: Cambridge University Press.

Stamatin, V. (2010). The Social Perception of Disabled People in Romania. Doctoral Thesis Summary. University Cluj-Napoca. Faculty of Sociology and Social Assistance. 
Waldschmidt, A. (2009). Disability policy of the European Union: the supranational level. European Journal of Disability Research, Vol. 3(1), pp. 8-23.

Weaver, K. (2009). Target Compliance: The Final Frontier of Policy Implementation. Issues in Governance Studies, No. 27, 30 September.

Wild, L., Chambers, V., King, M., and Harris, D. (2012). Common constraints and incentive problems in service Delivery. ODI Working Paper 351. London: Overseas Development Institute. 


\title{
EU social inclusion policy implementation in Poland | 989-20 I 8
}

\author{
Ryszard Szarfenberg
}

\section{Introduction}

The concepts of social inclusion (integracja społeczna) and social exclusion (wykluczenie spoteczne) were introduced into the Polish social policy agenda in the early 2000s. However, the assumption that this also started Polish social inclusion policy is unconvincing. Let us assume as a starting point that the universal core meaning of the social inclusion concept is to help those persons who are long-term unemployed or outside the labour market to get a job and to protect their income while they are without earnings from work (temporary protection from poverty) [on activation regimes in Europe, see Serrano Pascual and Magnusson, 2007]. Many categories might be target groups for such a social inclusion policy, e.g. older unemployed, disabled, women with children, caregivers to adult dependants, addicts, ex-convicts, youth at risk of exclusion, lowqualified unemployed, and asylum seekers. These categories had been recognized well before Poland's accession to the European Union (EU), and people with disabilities were recognized early in the emerging labour market policy (Act On Employment, 1989) together with youth at risk of exclusion (Act On Employment and Unemployment, 1991). ${ }^{1}$ The separate disability policy that focused on vocational rehabilitation services and sheltered employment was well developed in the socialist period and was quickly regulated by the new separate act (Act on Employment and Vocational Rehabilitation of Disabled People, 1991). The first list of groups at risk for labour market exclusion as a target for special programmes was adopted in 1995. Among them were those unemployed longer than a year, single parents, unemployed couples, people without qualifications or lowqualified, those without jobs after liquidation of state farms, graduates, and exconvicts (Directive on Special Programs in Counteracting Unemployment, 1995).

Finally, they were also recognized in the social assistance system with its primary goal of meeting people's needs and enabling living in dignifying conditions, but also its secondary goals such as making people independent from social assistance and integrating them into the social environment (Act on Social Assistance, 1990). On the list of eleven reasons justifying delivering social 
assistance were poverty, orphanhood, homelessness, the need to protect motherhood, unemployment, physical or mental impairment, long-term illness, helplessness in care and educational matters and in running a household (especially in single-parent or multi-child families), alcoholism or drug addiction, and difficulties in adapting to life after leaving prison.

This chapter first presents a literature review with a focus on the development of Polish social inclusion policy and the impact of the EU social inclusion policy on this process. Theoretical and methodical details are described and explained in the second section. The subsequent three sections are organized within temporal logics related to accession to the EU: pre-accession 1989-2000, accession 2001-2006, and post-accession 2007-2018. Every section contains descriptions and institutionalist interpretations of Polish social inclusion policy changes along with one case that is important for understanding the EU social inclusion policy implementation in Poland in the specific period.

\section{Literature review}

There is a hypothesis that social or active inclusion policy (active social policy) was introduced long after the beginning of transition process: 'After 1989, Polish social policy was for approximately 15 years dominated by protective measures designed to counteract the negative side effects of the economic reforms' (Rymsza, 2013, p. 325), and, 'The social policy of the first post-transformation decade was focused not on activation, but basically on mitigating the side effects of the shock therapy that the economic system was undergoing' (Kaźmierczak and Rymsza, 2017, p. 125). Other researchers shortened the successful 'protective stage' to the first 5-6 years of the transition period, but in this interpretation the second half of the 1990 s was dominated by retirement pension reform (Inglot, 2009, pp. 87-88). The concept of active social policy emerged in Polish academic literature in the early years of the twenty-first century (Rymsza, 2003) and was subsequently developed on a conceptual level and inspired empirical research (Karwacki et al., 2014).

The theoretical framework and normative justification of European 'social inclusion through work' (versus the US concept of 'workfare') was an idea taken from Durkheim's theory of social cohesion through participation in the social division of work (Rymsza, 2013, p. 320). A recent conceptual development was the invention of two models of activation, namely the management of the underclass model focused on vocational (re)integration of the unemployed and economically inactive and the empowerment model focused on the social inclusion of 'helpless, socially unfit, disabled persons' (Rymsza and Karwacki, 2017, pp. 39-51). ${ }^{2}$

Polish active inclusion policy from the perspective of frontline delivery in social assistance and social integration centres was recently characterized as an optional activation model with strong discretion and without obligatory activation contracts or sanctions (Kaźmierczak and Rymsza, 2017, p. 141). More 
recent empirical research seems to come to a similar conclusion: 'Conditionality based on behavioural sanctions is not particularly well embedded in social assistance' (Poławski, 2018, p. 95). Western researchers compared the Polish model of activation policy to more developed models and concluded that the Polish model is underdeveloped but that there is a possibility of strengthening the emphasis on activation, and they proposed several reforms in that direction (Moreira and Lødemel, 2012, p. 150).

In the literature about Polish social inclusion (activation) policy summarized above, there is a thesis that the very genesis of Polish activation policy was directly linked to the EU and its social inclusion policy:

Increased interest in the concept of active social policy resulted from the conjunction of two factors: (1) Poland's nationally specific experiences of economic and political transformation, one of the corollaries of which is the conviction that protective social policy measures have largely outlived their usefulness; and (2) the implementation of EU priorities in the field of active labour market policy and active social policy.

(Rymsza, 2013, p. 322)

Other authors declared in the context of Europeanization of Polish social policy, 'The current system of social assistance (care and rescue) has been gradually transformed into a system of social integration and activation since 2004' (Danecka, 2014, pp. 132-133).

In the literature directly related to implementation of the EU social inclusion policy, there is a focus on the strategic (Zieleńska, 2015, 2018; Szarfenberg, 2013, 2015b) and operational level (ESF projects). In the process of drafting the main Polish social Open Method of Coordination (OMC) document, ${ }^{3}$ different departments from different ministries delivered their contributions sometimes with delays and not as expected by the coordinating department. The final result was described as a patchwork of weakly adjusted parts, and this was interpreted as a reproduction of the organizational structure of the government administration involved in the drafting process (Zieleńska, 2015, p. 186). The main message seems to be that there are multiple communication and organizational obstacles in implementing the EU social OMC in Poland. Though something had been implemented as a required document, its impact on the policy-making and the reality seems to have been very limited.

The stake in the game of compliance was the EU funds for Poland that had been negotiated for the new financing period 2014-2020 (Zieleńska, 2018). Three arguments support this gaming interpretation. First, government responses to social Country Specific Recommendations (CSRs) were positive (generally that the government was doing a lot) but without any substantial increases in social expenditures outside the EU funds. Second, the Polish government was under the Excessive Deficit Procedure (2009-2015), which restricted its decisions regarding social spending. Third, the EU indicator of being at risk of 
poverty or social exclusion decreased substantially, thus reducing the internal pressure and weakening social inclusion on the government's agenda.

The operational level of implementation of the EU social inclusion policy should not be neglected. ${ }^{4}$ The EU social or active inclusion policy was also implemented in Poland within the European Social Fund (ESF) architecture from negotiating and drafting priorities of operational programmes (Szarfenberg, $2012,2013,2015$ a) to the concrete active inclusion projects carried out by public social assistance units at the local government level (Miżejewski and Ołdak, 2011; Szarfenberg, 2015b). In the Polish case for the mid-term of the 2007-2013 perspective, the conclusion was rather positive:

... many new solutions have been introduced under the influence of the European Commission. ... There were a number of new ideas and activities, new concepts and local solutions that should become the norm in social assistance in the future.

(Miżejewski and Ołdak, 2011, p. 358)

The main contribution of this chapter to the above literature is based on the analysis of the long period from the start of transition (1989) to the most recent events (2018) within an institutionally embedded multi-level implementation framework.

\section{Theoretical and methodological perspective}

The Europeanization literature recognizes two research approaches to implementation of EU policies in member states - namely top-down and bottom-up approaches (Exadaktylos and Radaelli, 2009). The first seeks evidence for the impact that specific EU policies have on Polish policy. In the second approach, the starting point is Polish social inclusion policy with its long-term dynamics, and the main task is to explain such policy with the EU as one of the multiple internal and external factors. For this chapter, the second perspective is more important.

Historical institutionalism (e.g. Hall, 2016) will be applied here as the conceptual framework for the explanation of long-term changes in the welfare-state institutions (Lynch and Rhodes, 2016) because Polish social inclusion policy developed in the long term as a set of weakly interrelated institutions. The main analytical concepts used here are path dependence, critical juncture, unintended consequences, actors, and policy ideas. Path dependence allows one to explain continuity in social policy (for an early critique, see Kay, 2005). Pre-existing institutions with their histories and vested interests are difficult to change and are prone to institutional inertia. The concept of critical juncture is useful in explaining changes in institutional frameworks (Capoccia, 2016). For Poland and similar post-socialist countries, the first candidate phenomenon of this kind is the transition from an undemocratic and centralized political system and nationalized 
economy to decentralized democracy with a free-market private economy. Together with economic conditions, there was a window of opportunity for change in many social policy institutions and for creating new ones (for an early assessment, see Księżopolski, 1993). Social policy is not free from unintended consequences, and such consequences include unemployment or poverty traps, and disincentives to work, as well as benefits cheating or non-use by people entitled to them (for an example from the US, see Bitler and Karoly, 2015). Recognizing them is one of the reasons for adjusting existing institutions to address unintended consequences. Without actors who promote or resist institutional change, it is difficult to understand it (Sharpf, 1997). The Polish transition created new political, administrative, and non-governmental actors, and changes in the institutional framework of social policy added new actors, e.g. social cooperatives created by a legal act, which subsequently became a reality with emerging actors representing their ideas and interests on different levels. Actors with advocacy coalitions are undertaking complex strategic actions to change existing institutions and to create new ones (for a recent overview, see JenkinsSmith et al., 2018). Finally, new ideas have gained more and more attention in research on policy change (Schmidt, 2008), including social policy (Béland, 2016). Influential ideas that were imported from the EU policy documents are in the Polish case social exclusion (wykluczenie spoleczne), social integration and reintegration (integracja społeczna, reintegracja społeczna), active inclusion (aktywna integracja), and active social policy (aktywna polityka społeczna). For Polish actors involved in the social inclusion policy processes, these ideas were important as instruments of framing the debate about social problems (from poverty to social exclusion) and their preferred solutions (from cash benefits to activation services).

The third cornerstone of the research approach is the selection of three cases involving possible contributions from the EU level over three decades of Polish social inclusion policy. The first is related to the failure of minimum income reform from the 1995-1996 period in the context of the EU recommendation in this area. The second case is based on the participatory drafting and adopting by the government of the first Polish National Strategy of Social Integration (Narodowa Strategia Integracji Spotecznej, 2004) within the process of joining the EU social OMC. The third case is related to the similar strategy from 2014 that fulfilled the ex-ante conditionality for the ESF financing period 2014-2020.

There were three main sources of data and insights for the analysis in this chapter. The first consisted of legal acts (adopted and proposed) regulating Polish social inclusion policy over the three decades since 1989. The assumption is that these acts represent complex institutions that can be understood as rules in law vs. rules in use, e.g. labour market policy as an institution has developed over time in response to four subsequent legislative acts. The second source consisted of strategic documents in this area, especially the National Strategy for Social Integration (Narodowa Strategia Integracji Społecznej, 2004) and the Programme for Counteracting Poverty and Social Exclusion: New Dimension of 
Active Integration (Krajowy Program przeciwdziałania ubóstwu i wykluczeniu społecznemu. Nowy wymiar aktywnej integracji, 2014). These are statements of the government's intentions and are not legally binding. The third source comprised personal documents (e.g. notes from meetings) of the author, who was involved as an expert in drafting the second type of documents and who was engaged as the EAPN Poland representative in the EU processes of social OMC under the Lisbon Strategy and the European Semester under the Europe 2020 strategy. The author is aware of possible biases of being a part of the researched processes, e.g. by focusing mainly on what was his direct experience and seeing the process from only one institutional actor point of view.

This research has an exploratory character both in terms of methodology (bottom-up Europeanization within an institutionalist conceptual framework) and in terms of the substantial social inclusion policy development in Poland, and it accounts for causal mechanisms of Europeanization.

\section{Failure of the EU social inclusion policy implementation in pre-accession Poland (1989-2000)}

Unemployment and poverty are two key issues for social inclusion policy, but these were nearly absent in socialist Poland's policy agenda. The reasons for this were both ideological and economic. The former was related to the assumption that socialism is better than capitalism in dealing with economic and social problems (Polakowski and Szarfenberg, 2018), and censorship prevented disseminating any information that questioned this assumption. ${ }^{6}$ The economic reason was based on the theory of economic planning; in the nationalized and centrally planned economy there should be full formal and insured employment, and thus no involuntary unemployment and no poverty.

The above conclusion does not mean that similar issues to those for social inclusion policy were totally absent in socialist times. The best example of a successful socialist activation policy is the vocational rehabilitation policy for people with disabilities undertaken in special cooperatives (e.g. Trampczynski, 1973). Some of the features underlined by the social inclusion approach, e.g. the comprehensiveness of policy measures, were well known in the rehabilitation literature and in practice. The concepts of social marginality or social pathology were also well recognized in the literature but were less visible on the level of policies, especially in the employment domain. In the full employment environment, it is difficult to recognize the involuntary exclusion from the world of work as a policy problem.

The designers of the transition strategy were aware of the risk of unemployment, and they created institutions for mitigating this, including employment services with unemployment benefits ${ }^{7}$ within a common legal framework (the Act on Employment of 1989 was replaced by the Act on Employment and Unemployment of 1991, and subsequently by the Act on Employment and Counteracting Unemployment of 1994). The first act embraced special groups 
and included vocational activation of the disabled (later in a separate act concerning vocational rehabilitation) and work corps for vulnerable youth.

For the rising wave of long-term unemployed who exhausted their entitlement to unemployment benefit (from 1993), there was a last-resort minimum income scheme with social assistance services and temporary benefits (Act on Social Assistance, 1990). This existed in socialist Poland, but only at the margin of the full employment and not for the people who were able to work (those unwilling to work were treated with a punitive approach; see the comparative framework in Romano, 2014).

These policy developments in the 1990s were undertaken in the context of the systemic transition from the Communist Party-dominated centralized politicoadministrative system and nationalized centrally planned economy to the competitive and decentralized (but still unitary) democracy and private free market economy. In this new and evolving institutional and economic framework, new actors emerged, including political (new parties), administrative (new independent local governments), economic (new private companies), and social actors (new non-governmental organizations [NGOs]). For social inclusion policy, two actors became of key importance - local governments and social NGOs. The former became important due to the decentralization of social assistance policy (from 1990), labour market policy, and disability policy (from 1999 the administrative reform adding a new secondary level of local government). The latter, in turn, became important due to the general trend for the privatization of the delivery of social services.

The basic institutions of Polish social inclusion policy emerged from the start of the economic and political transition. The main legal framework was developed in several laws related to unemployment, disability, and social assistance from the early 1990s. Characteristic features of this development were the gradual restriction of access to the unemployment benefit, lowering its level, the development of activation benefits, the rise of the focus on at-risk groups, and the lack of guaranteed social assistance for the unemployed (with some exceptions for single parents [Szylko-Skoczny, 2004]).

\section{Case I Guaranteed minimum income}

The social assistance act from 1990 established a new legal framework for minimum income in post-socialist Poland. Its main cash instrument for unemployed non-disabled people of working age was a temporary benefit. Entitlement to it required not only living in income poverty, but also experiencing a 'difficult situation' - also called a 'dysfunction' - such as unemployment. Fulfilling these conditions did not guarantee the benefit, however, and in the law it was stated that it only 'might' be granted, and social assistance offices sometimes rejected claims due to the lack of financial resources. In 1993 this was a common occurrence as the first wave of unemployed lost their unemployment benefits and started to claim temporary benefits. 
Early attempts to make temporary benefit genuinely guaranteed, i.e. the introduction into Polish law of a guaranteed minimum income, started officially in 1995. In the parliamentary speech justifying the government's proposal for an amendment to the social assistance act, there was a reference to the process of ratification of the European Social Charter (ESC, signed in 1991 when Poland joined the Council of Europe). The Government, however, abandoned its own proposal in this regard in 1996. Ratification of the ESC (1997) was finally completed with substantial exceptions in Article 13, establishing the right to social and health assistance. The first Polish National Programme for the Adoption of the Acquis (1998) included an item (29.17) about the necessity of implementing the Council recommendation on common criteria concerning sufficient resources and social assistance in social protection systems (92/441/EEC). This was one of the early EU soft laws regarding social inclusion policy. There was short notice about abandoning this point in the implementation report of the National Programme due to the substantial financial cost for the public budget (Szarfenberg, 2010).

\section{Institutional interpretation}

The systemic transition process was started in 1989, and it was a critical juncture for new social inclusion policy institutions in Poland. This juncture started new path dependencies for the subsequent institutional developments. The first legislative acts regulating labour market policy with recognition of special groups (the disabled and vulnerable youth in particular) and social assistance with the goal of making recipients independent and integrated within the community were in force in the same or following year. The separate institutionalization of the policy for people with disabilities added a third social inclusion policy venue for this special group. Other special at-risk groups were also recognized within the framework of labour market policy, and special measures and programmes were developed for them. In terms of services, three broad types were recognized - employment services, social work, and rehabilitation. None of these was new, but they operated in the new legal, economic, political, and social context. Within labour market policy, new forms of cash benefits were established. Unlike in the socialist period, the registered unemployed were also recognized as entitled to social assistance in the form of cash benefits. One of the later effects of the critical juncture worth noticing is the reform of family benefits. Their institutional nature was radically changed from being based on a social insurance to a social assistance principle (targeted to the poor families), but with making them much easier to access than standard social assistance benefits. Radical decentralization of the public administration even for employment services in the late 1990s completed the building of the institutional framework that had started with the critical juncture of the systemic transition.

The main unintended consequence of social policy development in the first years of the 1990s was economic deactivation of some categories of people, e.g. 
older workers, by making disability pensions and early retirement schemes more accessible, but also by other emergency measures for many workers made redundant by the economic transition. This seems to be a plausible explanation for the subsequent radical reforms of disability certification (splitting it into certification for the disability pension and for employment reasons) and retirement pensions (from defined benefit to the defined contribution principle). Together with restricted access to the unemployment benefit, this was the final act of making Polish social policy's post-transition path complete.

Within broader advocacy coalitions, two were important in the context of social inclusion policy. The first, which supported pro-market reforms, distrusted the welfare-state idea and was convinced that transition by shock therapy with temporary social protection for the losers was the best possible way forward. The second had many reservations with regard to the radical economic transformation necessary. The actors involved were very concerned about its social costs and were reluctant at the idea of the end of the welfare state that was popular at that time. The lost battle for a guaranteed minimum income from Polish social assistance even during the post-communist party government was a clear sign that the second coalition was weaker. Another point for crystallizing new coalitions was related to family benefits. On one side there was strong support for targeting of family benefits to families in poverty. Actors from the other conservative side disagreed and promoted universality.

The idea of multi-dimensional and dynamic social exclusion at that time was barely known. The main economic and social problems of the transition period were understood as monetary poverty explained by unemployment with the selfevident conclusion that fighting the latter was the best social policy strategy (e.g. Golinowska, 2002).

Case 1 is about the failure in implementing Poland's early EU social inclusion initiatives. Poland joined the Council of Europe in 1991 and had obligations to ratify its core conventions. One of them was the ESC, with Article 13 establishing the right to social assistance. Adoption of the EU law became a government programme in 1998, just after the ratification of the ESC. Article 13 was only partially ratified, without the main point about granting adequate assistance. The EU recommendation from 1992 was soft law, and the government decision was not to implement it, with the simple excuse that it would be too expensive.

\section{Partial success of the EU social inclusion policy implementation in the accession period (200I-2006)}

The most visible institutional innovation in Polish social inclusion policy in the accession period was social employment (Act on Social Employment, 2003). This created new social inclusion organizations (social integration centres and clubs), new social services offered by them (vocational and social reintegration training), and new cash benefits for participants (integration benefit, motivational 
premium). After six months of individualized vocational and social training combined with cash benefits, participants may be employed in supported employment by ordinary employers with partially refunded wages and social insurance contributions or become founders of social cooperatives with jobs subsidized for up to one year. Social cooperatives first introduced within the broader legal framework related to cooperatives were subsequently developed within a new law at the end of this period (Act on Social Cooperatives, 2006). Establishing social integration centres or clubs and social cooperatives was, however, not obligatory for local governments.

In the government proposal of the Act on Social Employment from 2003, there were many direct references to the EU treaties, the EU social inclusion policy, the European Employment Strategy, and the ESF implementation in 2004-2006 (fighting social exclusion in the operational programme). It seems that this was also an example of a 'usages of Europe' approach in the social inclusion area (Warleigh-Lack and Mccallion, 2012). Another source of inspiration mentioned there was the integration work of social enterprises in different EU countries, especially Italian social cooperatives. The Polish NGOs' contribution was also recognized.

In this period there were also changes in previously developed social inclusion policies, including the new Act on Promotion of Employment and Institutions of the Labour Market (2004) and the new Act on Social Assistance (2004). In the former, the special programmes for groups at risk were dropped probably due to moving these groups to be covered by the social employment act. The amendment in 2005 introduced a new activation instrument for the unemployed who were recipients of social assistance benefits, namely socially useful jobs (prace społecznie użteczne) for local governments in social services for not more than 10 hours a week. The cash benefit for that work (it was not a wage) was in a fixed amount for an hour (less than minimum wage divided by standard full-time work time). In case of the refusal of an offer of this kind of job, a sanction might be applied to social assistance benefits. What is also important is that the wage-benefit for that job may be combined with social assistance benefits without any restrictions for the latter, which is a rare exception.

The new social assistance act also brought several changes, e.g. the nonobligatory social contract, ${ }^{8}$ the temporary benefit being partially guaranteed (gradually to 50 per cent of top-up from 2008), the income test and minimum income standard being based on a modified subsistence minimum, and the verification mechanism with social partners to be performed every three years being introduced.

The Polish social inclusion policy was more institutionally fragmented after establishing the social employment measure. The non-obligatory character of the latter resulted in a rather low incidence of social integration centres and very low coverage for target groups (from 35 in 2005 to 159 in 2016, they covered only 1.4 per cent of the long-term unemployed). ${ }^{9}$ 


\section{Case 2 National Social Integration Strategy (Narodowa Strategia Integracji Społecznej, NSIS)}

In 2002, the social-democratic government (2001-2005) established a special task force (Zespót Zadaniowy do spraw Reintegracji Społecznej) ${ }^{10}$ to prepare a new and unprecedented strategic document that was not an obligatory element of the EU social inclusion OMC. Different actors were invited to participate, including representatives of several ministries (education, finance, administration, and justice), local government agencies, NGOs and social partners, international organizations (the UN Development Programme and the World Bank), individual countries (Germany, Austria, and France), and the European Commission. Four working groups were formed with responsibilities for research and indicators, the identification of inequalities in access to social services (later changed to the topic of theory and values), social policy analysis, and good practices from NGOs. Every group had a chairperson from an NGO. Independent experts were invited to be secretaries for the groups, and there was an additional main academic expert. The head of the task force was the minister of labour and social policy, and the secretariat supporting and coordinating the process was established in the same ministry.

The principles founding the task force directly mentioned the Lisbon Summit and EU commitment to combating poverty and social exclusion and the Community Action Programme to Combat Social Exclusion 2002-2006. Poland joined the latter in 2002. The document contained a short criticism of the narrow understanding of social integration as merely the activation of those in the most difficult situations into the labour market. For a broader meaning, it pointed out the legislative proposal of the act on social employment.

The main output of that initiative was the National Strategy of Social Integration adopted by the government in 2004 for the period up to 2010. Each working group issued its final report, and the entire process was documented on the special web page dedicated to social inclusion in Poland. ${ }^{11}$

The final document was near 100 pages long. It embraced pre-school and school education, labour market and social insurance, healthcare, housing, transport and communication, social assistance, criminal justice, and culture. The link to the social exclusion idea was made by identifying several categories more at risk of exclusion, e.g. school dropouts, people with mental illnesses, those leaving prisons, the long-term unemployed, persons at risk of eviction, the homeless, immigrants working in informal jobs, former employees of state farms, alcohol and drug addicts, and the Roma ethnic minority.

Among 20 priorities, there were not only radical reduction of extreme poverty, reduction of long-term unemployment, and increased numbers of people participating in the ALMP, but also increased participation in pre-school education, improvement in the quality of lower and higher secondary education, reduction of income inequality, increased employment among people with disabilities, promotion of life-long learning and universal healthcare, and increased housing 
for people at risk of homelessness. For most of the priorities, the Strategy proposed indicators with targets for 2010 .

\section{Institutional interpretation}

The second critical juncture for Polish social inclusion policy was accession of Poland to the EU and its processes and strategies, especially to the European Employment Strategy (EES) and to the Social Inclusion Process (social OMC). According to path-dependence logic, new legislative initiatives in social inclusion policy were bounded by previously adopted and implemented institutions. There were at least two possible courses of action - incremental changes in preexisting institutions or creating new ones. As was described above, both were undertaken. New institutional innovations (social employment and social cooperatives) differed substantially from already established labour market policy, social assistance, rehabilitation, and employment for the disabled. Local governments were not obliged to run such programmes, and for NGOs their organization and financing was a very complex task. One possible explanation might be institutional development in the past that made it more difficult to introduce a completely new institution related to some marginalized groups (e.g. for a group other than the disabled or marginalized youth) when there was a pre-existing complex institutional mix also embracing some more vulnerable groups within multi-level public administration. The economic context of the recession in the years 2002-2004 was also very unfavourable for convincing the Ministry of Finance to fund new social expenditures. The perspective of ESF financing gave hope that the EU funding would be the solution.

The main mechanism of unintended consequences after introducing new institutions was the growing complexity of the institutional mix. It was plagued with problems of coordination and collaboration between central, regional, and two local administrative levels, between different social inclusion institutions (mainly employment bureaus and social assistance centres), between public and private, and between the for-profit and not-for-profit sectors. This new dimension of complexity came with temporary projects financed by the ESF money, and the coordination between what were standard practices within a changing legal framework and what was required by ESF procedures also changed from one financing period to another.

The introduction of the new social employment institutions had its proponents. The relative weakness of their status within institutional frameworks, as explained above, constantly mobilized these institutions to use EU strategies and ESF money as permanent supporting mechanisms. The oppositional coalition was not very strong because of the division between neoliberal actors who contested the very need for new institutions (they were then in the political opposition) and communitarians who valued NGOs as civic society manifestations, but who also saw collaboration with public administration as a threat to the independence and the real mission of non-governmental organizations. 
In the ideational sphere, social exclusion and social integration or inclusion emerged as new ideas and were hotly debated, for example the relation with older Polish terms like social marginality or marginalization. The multidimensionality and processual character with the heterogeneity of the population at risk made these concepts difficult to grasp, to measure, and to indicate in concrete terms in policy instruments as solutions. New ideas were defined in the National Strategy for Social Integration in general terms and with a plethora of priorities. Another new idea introduced at the same time was about the social economy, with discussion about old (traditional cooperatives) and new economies under the influence of experience relating to Italy (social cooperatives types A and B).

Case 2 is related to an innovative and participatory process started in 2002, the main output of which was the first Polish social inclusion strategy adopted by the government in 2004. The scope of this strategy was much broader than the narrow meaning of social inclusion as economic activation of hard-to-employ people. Together with the above-mentioned institutional innovation of social employment, this is clear evidence of the EU social inclusion policy's impact on the Polish social policy agenda.

The results of these processes show a clear duality between implementation of the social inclusion OMC and implementation of the emerging social inclusion part of the EES and ESF was begun. The former was underfinanced, understaffed, and without legal basis in Polish hard law. ${ }^{12}$ The main focus of implementation was on creating strategic documents that were obligatory in the social OMC (National Action Plan for Social Integration ${ }^{13}$ ). The latter was within the broader context of the EU economic and employment strategy and funds. It was well financed, with its own personnel, and with a basis in EU and Polish law. Main focus of the EU policy implementation in this area was on absorption and spending a huge amount of EU money on concrete projects that were national, regional, or local in scope.

\section{Preserving the legacy of previous successes: the EU social inclusion policy implementation in the post-accession period (2007-2018)}

The national strategy prepared during the accession period and adopted in 2004 was a strong incentive for subsequent developments on the legal front. There was an advanced proposal for introduction of the new institutional architecture for broad social inclusion policy planning and implementation within multi-level governance (Proposal of the Act on Principles of Conducting Social Policy, 2007). In the first article of this legislative proposal, it was stated that 'the act defines the principles of planning, implementation and evaluation of social policy conducted in the framework of development policy and as part of the EU undertakings for employment, development of human resources, and social integration, as well as entities implementing this policy' (ruling coalition MPs' 
proposal). In the same proposal, there was an amendment to the Act on Social Assistance, adding the whole new chapter under the title 'Tools and Instruments of Active Integration', with a classification of instruments into separate categories of vocational, educational, health, and social activation. In the same year the ruling conservative coalition (2005-2007) fell apart and the mandate of parliament was shortened. In the new elections, the liberal opposition won and it was not interested in the continuation of this proposal, even the restricted version. The opposition party MPs' proposal (2008) was finally rejected after the negative opinion of the government. ${ }^{14}$

During this period, Polish social inclusion policy development seems to have been more under the influence of path-dependent logics. There are four core institutionalized policies in this area-employment promotion, social assistance, vocational and social rehabilitation, and social employment with social cooperatives. In the organizational structure of the ministry responsible for work and social protection, both social assistance and social employment are within one department previously responsible for social assistance only (Departament Pomocy i Integracji Spolecznej). A separate department is responsible for labour market policy (employment promotion). Social cooperatives and social economy are in another department. ${ }^{15}$

Developments in the third analysed period took place inside already institutionalized venues. Employment promotion was reformed extensively in 2014, but minor changes had also been introduced previously (e.g. the regressive unemployment benefit). The amendments combining socially useful jobs with reintegration services in one short (two-month) programme called activation and integration (program aktywizacja i integracja) were relevant to social inclusion. The main target group for this programme was the unemployed, who were also social assistance clients, profiled as the third category of support measures and who had signed the social contract. ${ }^{16}$ This new programme seems to be the sign of a duplication of social employment, but in a very rudimentary form. Instead of an entire institutional structure with special reintegration services and integration cash benefits over six months of an individualized programme in a special organization, we have a combination of work requirement for local government combined with activation services shortened to two months (with the possibility to extend it to six months). ${ }^{17}$ Supported employment introduced with social employment is now also for graduates of this new activation and integration scheme.

Social cooperative institutions, previously only one of the possibilities for graduates in social employment, gained more and more importance and independence from its earlier subordinated status. It was reformed substantially in 2009. The main intention seems to have been to address the barriers to social cooperatives' development (not more than 100 had emerged in the years 2004-2007). Among many amendments, there was the possibility of legal persons to be founders of the cooperative, and a change was made in the maximum number of nonexcluded people who could act as founders. Previously it was not more than 20 per 
cent, and it was then changed to 50 per cent. ${ }^{18}$ Those changes, as well as the funds from the ESF 2007-2013 for subsidizing jobs in social cooperatives, resulted in the substantial increase of the number of these organizations (there were 900 active entities in $2016^{19}$ ). Amendments with similar intentions were introduced in 2018, and an extensive system of support for social cooperatives (and other social economy units) is being continued within the ESF 2014-2020 period.

This area seems to be most fruitful for the new strategic and institutional initiatives. As for strategic documents, the key is the National Programme for Social Economy Development (Krajowy Program Rozwoju Ekonomii Społecznej) adopted in 2014 within the broader framework of strategic documents for the EU financing period of 2014-2020. Two legislative proposals have been brought forth since then, namely the proposal of the Act on Social Enterprise and Supporting Social Economy Entities ${ }^{20}$ and the current government's proposal of the Act on Solidarity and Social Economy (still in the consultation process as of early 2019).

The new government in office from 2015 implemented some new reforms, but outside the social inclusion logics. Its main preoccupation has been family policy. The government's flagship programme (called 500 Plus) is simply a new generous child allowance added to the existing family benefits (Act on State Aid in Education of Children, 2016). The policy reason for its introduction was mainly to stimulate birth numbers, but also to reduce child poverty. Both aims seem to be out with the social inclusion agenda focused on employment and adults.

\section{Case 3 Ex-ante conditionality and the successor of NSIS}

In the directive regulating EU structural funding for the 2014-2020 period, legislators used a new implementation tool, ex-ante conditionality. This is another tool in the international organization toolkit to influence national policies, e.g. conditions imposed by the IMF and World Bank in structural adjustment programmes (for an overview relating to the IMF, see Dreher, 2009; for the Eurozone case, see Greer, 2013).

For national policy related to poverty and social exclusion, the main condition was 'the existence and the implementation of a national strategic policy framework for poverty reduction aiming at the active inclusion of people excluded from the labour market in the light of the Employment guidelines'. ${ }^{21}$

At the time of starting the drafting of national documents for ESF implementation (2012), the government was not able to meet this condition. National actors involved in updating the National Reform Programme (EAPN Poland) raised the issue in 2012, and it was a concern for the ministry responsible for EU structural funds implementation (Ministerstwo Rozwoju Regionalnego). The first response from the other ministry responsible for social policy (Ministerstwo Pracy i Polityki Społecznej) was an attempt to extract the social elements from the main strategic document for employment, which was drafted at the same 
time (Strategia Rozwoju Kapitału Ludzkiego adopted in June 2013). The idea was to combine it with information provided by the Main Statistical Office (Gtówny Urzad Statystyczny) and the analytical unit of the social ministry. It is not clear why this idea was abandoned. The social ministry decided to appoint an independent expert ${ }^{22}$ as an informal coordinator for the process of drafting a new document. Supported by the ministry, by voluntary academic experts, and by representatives of eight NGOs, he managed to finish the final draft of the new programme. After official social consultations, the government adopted it in August 2014 (Krajowy Program Przeciwdziałania Ubóstwu $i$ Wykluczeniu Społecznemu 2020. Nowy wymiar aktywnej integracji).

\section{Institutional interpretation}

Path dependence seems to be a good explanation for survival of the social employment institution despite its weak status within the broader institutional framework. Its complexity made it difficult to introduce new institutions. Some failures can also be explained by external factors; for example the introduction of new social policy coordination (2006-2007) was blocked by the change of government (from conservative and more supportive of social policy initiatives to liberal and more reluctant to embrace them). The reform introducing more activation in social assistance also failed due to internal blockage by the Ministry of Finance.

Other policy failures are also illustrative of path dependence due to institutional complexity accumulated in the past, and the social cooperative institution is one of the puzzles within this complexity. From at least 2008 there were ongoing discussions about broadening the institutional scope under the heading of social enterprise and social economy. It seems that despite the extensive effort put in to this initiative, it will fail again, following its first failure prior to the previous elections in 2015. Another path dependence mechanism is embedded in the ESF programming. What was achieved in the 2007-2013 period was worth sustaining into the next financing period.

The critical juncture for social economy institutional development (i.e. a new and unprecedented strategic document) was the new EU financing perspective 2014-2020. As was explained above, a substantial share of the financial resources for Polish social inclusion policy comes from the ESF. What was developed in the previous period should now be programmed again in the discussion with other stakeholders. Ex-ante conditionality was a part of the critical juncture mechanism in the case of the 2014 strategic framework for active integration described here in Case 3 (but social economy was not mentioned in the conditionality framework ${ }^{23}$ ).

Institutional complexity might be interpreted as an unintended consequence of previous developments, and it continues to be a part of the makeup of institutional development. Duplication of social employment in the form of a simplified and shortened activation and integration programme seems to be an interesting and illustrative case. 
Regarding the actors and their coalitions, what arises in this period is the consolidation of two camps within social economy institutional development. The social cooperatives camp is successfully finding a way not only to sustain, but also to strengthen this institutional development using the EU social economy documents as support and ESF funds for financing the implementation of the National Programme for Social Economy Development. The opposition coalition seems to be more and more critical of this development mainly on the grounds that social cooperatives are too demanding an organizational form for work reintegration, and they preferred other simpler and easier forms such as not-for-profit companies. Another critical point is that too many financial resources are directed to the social cooperatives sector relative to other forms of civic organizations with other missions.

Ideational development was under the influence of the idea of active social policy, but its dynamic was undermined by the new government elected in 2015 and its idea of universal family policy. First, this was the least-explored topic in the active social policy discourse due to its gender blindness (Szarfenberg, 2016). Second, the institutional development of family benefits was focused on the cash benefits and child poverty, not on activation services for mothers at risk of social exclusion.

New institutions introduced before the analysed period survived, however, despite their weak relative status and complex implementation, but only social cooperatives have undergone marked institutional development. The same actors who were involved in their creation in the previous period are still mobilized for the idea of broader institutions of social economy. They have successfully used the EU policy documents and the ESF financing for the continued support of its promotion and development in Poland.

The working of the new EU mechanism of ex-ante conditionality in Poland is illustrated by Case $3 .^{24}$ It was used by non-governmental internal actors to strengthen the focus on poverty, social exclusion, and active integration in the government's agenda. The reforms of the labour market policy and social assistance were designed in separate processes, and the strategic document described in Case 3 did not change their paths - the first to the fragile success threatened by new initiatives (the proposal of the Act on Labor Market ${ }^{25}$ ) and the second to failure.

\section{Conclusion}

Summing up, Polish social inclusion policy was built as a set of weakly connected institutions as a result of the critical juncture of systemic transition and its economic and politico-administrative consequences. The three main institutions of labour market, vocational and social rehabilitation, and social assistance were completed within a new administrative structure well before accession to the EU. The resulting path dependence mechanism restricted institutional innovation in social inclusion policy despite the new critical juncture of the accession process. 
Incremental changes toward more activation in existing institutions were made without any breakthroughs, but also new institutions emerged. Their relative status in comparison to established institutions was, however, weak and they needed the constant support and mobilization of advocacy coalitions. Determined actors who recognized the power of the European Union's ideas and funds in relation to domestic social policy have successfully harnessed this power to maintain the new status quo and to selectively strengthen what they previously achieved. They are still mobilized and put great effort into the development of a broader institution of social economy embracing much more than social cooperatives and making a fragmented system more coordinated at the governance level and in the local delivery of social services.

The explanation for the partial success of EU policy implementation around the time of accession is complex. First, the Lisbon Strategy introduced the social OMC, which was new and strongly supported by the EU institutions in its first years. Second, it is obvious that in this period EU accession was high on the Polish government's agenda. Third, social policy was also high on the then social-democratic government's agenda. Fourth, unemployment and poverty, i.e. key issues for social inclusion, re-emerged as a result of severe economic recession (2002-2004). Fifth, during the recession the strategy of increasing social spending was not considered a possible solution. All in all, it was a favourable socio-political environment for institutional innovations in social inclusion policy. Due to institutional processes, the newly created institutions were weak and in constant need of external support.

The subsequent evolution of the EU social inclusion policy implementation in Poland might also be explained by several factors. First, social inclusion was less and less important on the EU policy agenda (especially from 2005), and the global economic crisis reinforced this trend with fiscal stability in the Eurozone being a priority. Second, after the accession, the economic situation in Poland eased and the global economic crisis hit Poland relatively less severely in comparison to other countries. Unemployment and poverty did not return as policy issues. Third, the main preoccupation of subsequent governments with the EU was an effective absorption of enormous amounts of EU funds mainly for infrastructural projects. Fourth, for the liberal coalition ruling Poland in the period 2007-2015 social policy was not as important as it had been for their socialdemocratic predecessors. Despite these factors, constant support for the new social inclusion institutions was sustained by path dependency in the ESF 2007-2013 period and by mobilization of actors in the programming of the 2014-2020 financial period.

The post-socialist past was important in this explanation in at least two ways. First, Poland was separated from Western Europe due to its forced belonging to the block of undemocratic countries with nationalized economies under Soviet domination. The deep economic crisis and martial law in the early 1980s dispelled any lingering illusions about the idealized socialist system as benevolent for the working class. The transformation from undemocratic socialism to 
democratic capitalism emancipated Polish aspirations to be part of Europe and the Western World. The EU was, however, less important to achieving this goal in the 1990s. Accession to other European and international organizations was easier, and their agendas were more important in that formative decade.

Second, it became clear at a very early stage that the transformation into capitalism has its damaging side effects, e.g. mass unemployment and the resulting poverty. These new social problems required a quick social policy response. Initially, it was delivered in the form of easily accessible permanent cash support in different forms within old and new institutional venues. In a very short time Poland developed its emergency welfare state, but this quickly became an unnecessary burden. Its successful retrenchment in the second part of the 1990s created a mature and implicit activation regime.

Institutionally embedded bottom-up Europeanization focused on rules and laws seems to be a useful conceptual framework for long-term, multi-centred and multiinstitutional analysis, but it needs further development, clarification, and testing with a more rigorous approach to obtaining data about institutions from a multitude of legal acts that are in a constant process of change. After the identification of all those changes in the specified period, their thorough classification is needed, e.g. fundamental or trivial changes. To make this possible, there needs to be a clear understanding of what social inclusion policy is and what all its possible models are. Finally, identified institutional dynamics need explanations, and here concepts derived from contemporary institutionalism seem to be indispensable.

\section{Notes}

1 The Disabled were listed under the heading 'vocational activation'. Responsibility for integration of youth at risk was granted to institutions developed in socialist Poland, and in the post-socialist era these were transformed into the youth education and employment agency (Ohotnicze Hufce Pracy). In the early 1990s the main target group was 'neglected and requiring special concern' or 'at risk, socially maladjusted and requiring special treatment' youth.

2 For a critical overview see: Szarfenberg (2016).

3 National Report 'Social protection and social integration' 2008-2010 (Krajowy Program 'Zabezpieczenie społeczne i integracja społeczna').

4 For confirmation of the ESF impact on activation policies for several countries, see Verschraegen et al. (2011) and van Gerven et al. (2014).

5 Cezary Miżejewski was a socialist MP in the 1990s and was an influential government official in the ministry responsible for social affairs in the process of joining Poland to the EU social inclusion process (2001-2005), and he retained his position even during new conservative government mandates (2005-2007). He is also a member of the Executive Council of the EAPN Poland.

6 The first Polish estimation of a social minimum (reference budget) important for assessment of the extent of poverty was published in 1971, but not for public dissemination and with confidentiality stamps ('tylko do użytku służbowego') [Tymowski, 1971; see Romano, 2014, pp. 37-39].

7 Early attempts to introduce unemployment insurance failed (announced in the 1994 government strategy; Piotrowski, 1995). Unemployment benefits were and still are financed from the Labour Fund, for which the main source of revenue is the 
obligatory employer contributions. From 1992, the level of these benefits has not been related to previous earnings.

8 It was made obligatory at first, but very quickly the government withdrew this condition from the enacted act by amendment.

9 For assessment of the decentralization of Polish social policy, see SztandarSztanderska and Mandes (2015) and Mandes (2016).

10 The first meeting was in November 2002.

11 In the domain name there was found the word 'reintegration'; www.reintegracja.gov. pl. It ceased to function around 2007-2008. This may be interpreted as an indicator of the weakening of social integration issues in the government and ministry agendas.

12 In the case of the EES, an obligation to adopt the National Action Plan for Employment (Krajowy Plan Działań na rzecz Zatrudnienia) was written into labour market policy legislation in 2004, and the first plan was adopted in 2005. Subsequent documents of this type were adopted for the years 2006, 2007, 2008, 2009-2011, 2012-2014, 2015-2017, and 2018. In the last plan there is an announcement of introducing '.. legislative works that provide for the discontinuation of this document due to the exhaustion of its current formula and too little added value' (Krajowy Plan Działań na rzecz Zatrudnienia na rok 2018, p. 5).

13 From the second document the name was changed substantially. The phrase 'plan of action' was replaced by the word 'programme' translated into English as 'report': http://ec.europa.eu/employment_social/social_inclusion/docs/2006/nap/poland_pl.pdf.

14 Instruments of active integration however, did not vanish. The same classification was a part of the Polish ESF operational programme 2007-2013 (Program Operacyjny Kapital Ludzki; see Miżejewski and Ołdak, 2011). It is interesting as to how some parts of the agenda of previous governments survived in the ESF implementation documents.

15 Until 2016 Departament Pożytku Publicznego. Its name was changed recently and now includes only social and solidarity economy: Departament Ekonomii Społecznej $i$ Soildarnej. It was related to reorganization of competences within government (general issues of NGOs were transferred to the Prime Minister's Bureau and independent agencies).

16 The amendments introduced obligatory profiling for all unemployed registered in employment services (for an extensive critique of this measure see Niklas et al., 2015).

17 The ministry responsible for labour market policy issued guidelines in 2014: Program Aktywizacja i Integracja - kierunkowe wytyczne dla podmiotów organizujacych Program Aktywizacja i Integracja: http://mcps-efs.nazwa.pl/upload/File/ops_pup/pai_ wytyczne.pdf.

18 For an extensive critique of this proposal see Szarfenberg (2008).

19 Data from Spótdzielnie socjalne w 2016 r. published by Main Statistical Office (Gtówny Urząd Statystyczny) in 2018.

20 On MPs' initiative, it obtained official status in parliamentary procedure in April 2015 , but it was not adopted before the elections. Work on the project and broader reform in this area started officially in 2008 by establishing a special task force (Zespót do spraw rozwiazań systemowych $w$ zakresie ekonomii społecznej, prime ministerial decision from December 2008).

21 Regulation (EU) No 1303/2013 of the European Parliament and of the Council of 17 December 2013 laying down common provisions on the European Regional Development Fund, the European Social Fund, the Cohesion Fund, the European Agricultural Fund for Rural Development, and the European Maritime and Fisheries Fund and laying down general provisions on the European Regional Development Fund, the European Social Fund, the Cohesion Fund and the European Maritime and Fisheries Fund and repealing Council Regulation (EC) No 1083/2006. 
22 Cezary Miżejewski - well-known policy architect of the social employment and social cooperatives institutions, member of the EAPN Poland.

23 It seems to have changed in the next ESF period because social economy was mentioned in legislative proposals within the conditionality concerned with A strategic policy framework for active labour market policies.

24 It should be noted that early European Semester Country Specific Recommendations for Poland (2012 and 2013) mentioned poverty. It was not about general poverty with specific at-risk groups but in-work poverty. Internal social actors attempted to use it as policy advocacy tool, but it was dropped from 2014 CSRs without any official explanation.

25 The entry into force was planned for 1 January 2019, but the government withdrew the proposal of the new act for unclear reasons.

\section{References}

Béland, D. (2016). Ideas and institutions in social policy research. Social Policy and Administration 50(6), pp. 734-750.

Bitler, M.P., and Karoly, L.A. (2015). Intended and unintended effects of the war on poverty: what research tells us and implications for policy. Journal of Policy Analysis and Management 34(3), pp. 639-696.

Capoccia, G. (2016). Critical junctures. In: O. Fioretos, T.G. Falleti, and A. Sheingate, eds., The Oxford handbook of historical institutionalism. Oxford: Oxford University Press.

Danecka, M. (2014). Partycypacja wykluczonych. Wyzwanie dla polityki społecznej. Warszawa: Oficyna Naukowa.

Dreher, A. (2009). IMF conditionality: theory and evidence. Public Choice 141(1-2), pp. 233-267.

Exadaktylos, T. and Radaelli, C.M. (2009). Research design in European studies: the case of Europeanization. Journal of Common Market Studies 47(3), pp. 507-530.

Golinowska, S. (2002). Poverty in Poland. Causes, measures and studies. In: M. Beblo, S. Golinowska, C. Lauer, K. Piętka, and A. Sowa, eds., Poverty dynamics in Poland: selected quantitative analyses. Warszawa, Manheim: CASE/ZEW.

Greer, S. (2013). Structural adjustment comes to Europe: lessons for the Eurozone from the conditionality debates. Global Social Policy 14(1), pp. 51-71.

Hall, P.A. (2016). Politics as a process structured in space and time. In: O. Fioretos, T.G. Falleti, and A. Sheingate, eds., The Oxford handbook of historical institutionalism. Oxford: Oxford University Press.

Inglot, T. (2009). Czech Republic, Hungary, Poland and Slovakia: adaptation and reform of the post-communist 'emergency welfare states'. In: A. Cerami and P. Vanhuysee, eds., Post-communist welfare pathways: theorizing social policy transformations in Central and Eastern Europe. Basingstoke: Palgrave Macmillan.

Jenkins-Smith, H.C., Nohrstedt, D., Weible, C.M., and Ingold, K. (2018). The advocacy coalition framework: an overview of the research program. In: C.M. Weible and P.A. Sabatier, eds., Theories of the policy process. London: Westview Press.

Karwacki, A., Kaźmierczak, T., and Rymsza, M. (2014). Reintegracja. Aktywna polityka społeczna w praktyce. Warszawa: Instytut Spraw Publicznych.

Kay, A. (2005). A critique of the use of path dependency in policy studies. Public Administration 83(3), pp. 553-571. 
Kaźmierczak, T. and Rymsza, M. (2017). Activation work within the social welfare system: the case of Poland. In: R. van Berkel, D. Caswell, P. Kupka, and F. Larsen, eds., Frontline delivery of welfare-to-work policies in Europe: activating the unemployed. New York: Routledge.

Księżopolski, M. (1993). Social policy in Poland in the period of political and economic transition: challenges and dilemmas. Journal of Social Policy 3(3), pp: 177-194.

Lynch, J. and Rhodes, M. (2016). Historical Institutionalism and the Welfare State. In: O. Fioretos, T.G. Falleti, and A. Sheingate, eds., The Oxford handbook of historical institutionalism. Oxford: Oxford University Press.

Mandes, S. (2016). Activation policies in a fragmented welfare system: the case of Poland. In: M. Heidenreich and D. Rice, eds., Integrating social and employment policies in Europe: active inclusion and challenges for local welfare governance. London: Edward Elgar.

Miżejewski, C. and Ołdak, M. (2011). Wdrażanie Programu Operacyjnego Kapitał Ludzki w obszarze pomocy i integracji społecznej. In: W. Anioł, M. Duszczyk, and P. Zawadzki, eds., Europa socjalna. Iluzja czy rzeczywistość? Warszawa: ASPRA-JR.

Moreira, A. and Lødemel, I. (2012). Zarządzanie aktywizacją. Polska na tle Europy. In: T. Kaźmierczak and M. Rymsza, eds., W stronę aktywnych stużb społecznych. Warszawa: Instytut Spraw Publicznych.

Niklas, J., Sztandar-Sztanderska, K., and Szymielewicz, K. (2015). Profiling the unemployed in Poland: social and political implications of algorithmic decision making. Warszawa: Panoptykon. https://panoptykon.org/sites/default/files/leadimage-biblioteka/ panoptykon_profiling_report_final.pdf.

Piotrowski, W. (1995). Uwagi na temat programu reformy ubezpieczeń społecznych w Polsce. Ruch Prawniczy, Ekonomiczny i Socjologiczny LVII(4), pp. 19-32.

Polakowski, M. and Szarfenberg, R. (2018) Social policy in the mature socialism period 1956-1980. Polityka Społeczna, English issue 14(1), pp. 8-14.

Poławski, P. (2018). Punitywność i sankcje socjalne w pomocy społecznej. In: P. Poławski, ed., Warunkowość i kontraktualizm w pomocy społecznej. Lokalne zróżnicowania i konsekwencje. Warszawa: Instytut Pracy i Spraw Socjalnych.

Romano, S. (2014). The political and social construction of poverty: Central and Eastern European countries in transition. Bristol: Policy Press.

Rymsza, M. (2003). Aktywna polityka społeczna w teorii i praktyce. In: T. Kaźmierczak and M. Rymsza, eds., W strone aktywnej polityki społecznej. Warszawa: Instytut Spraw Publicznych.

Rymsza, M. (2013). Two decades of social policy in Poland. From protection to activation of citizens. In: A. Evers and A.-M. Guillemard, eds., Social policy and citizenship. The changing landscape. Oxford: Oxford University Press.

Rymsza, M. and Karwacki, A. (2017). Między podejściem empowerment a zarządzaniem underclass. Dwa modele aktywizacji w polityce społecznej. In: A. Karwacki, M. Rymsza, B. Gąciarz, T. Kaźmierczak, and B. Skrzypczak, eds., Niezatrudnieniowe wymiary aktywizacji. W strone modelu empowerment. Toruń: Wydawnictwo Naukowe UMK.

Scharpf, F. (1997). Games real actors play: actor-centred institutionalism in policy research. Boulder: West View Press.

Schmidt, V.A. (2008). Discursive institutionalism: the explanatory power of ideas and discourse. Annual Review of Political Science 11(1), pp. 303-326. 
Serrano Pascual, A. and Magnusson, L., eds. (2007). Reshaping welfare states and activation regimes in Europe. Bruxelles, Bern, Berlin, Frankfurt am Main, New York, Oxford, Wien: PIE Lang.

Szarfenberg, R. (2008). Opinia na temat projektu nowelizacji ustawy o spótdzielniach socjalnych. Polskie Towarzystwo Polityki Społecznej.

Szarfenberg, R. (2010). Minimalny dochód gwarantowany i pomoc społeczna. In: C. Żołędowski, R. Szarfenberg, and M. Theiss, eds., Polityka publiczna wobec ubóstwa $i$ wykluczenia społecznego. Warszawa: Elipsa.

Szarfenberg, R. (2012). Nowy priorytet EFS - promowanie właczenia/integracji społecznej i zwalczanie ubóstwa. Ekspertyza dla Ministerstwa Rozwoju Regionalnego.

Szarfenberg, R. (2013). Organizacje pozarządowe w procesie programowania polityk publicznych. Zoon Politikon (4), pp. 29-40.

Szarfenberg, R. (2015a). Organizacje obywatelskie promuja włączenie społeczne, walcza $z$ ubóstwem $i$ wszelka dyskryminacja poprzez projekty finansowane z regionalnych programów operacyjnych 2014-2020 Przewodnik. Projekt 'W stronę skutecznego modelu partycypacji obywatelskiej’. Warszawa: Wspólnota Robocza Związków Organizacji Socjalnych.

Szarfenberg, R. (2015b). Konkretyzacja i koordynacja celów polityki publicznej w wielopoziomowym rządzeniu. Przykład celu Unii Europejskiej w zakresie ubóstwa. Studia z Polityki Publiczneji 2(2), pp. 41-56.

Szarfenberg, R. (2016). O genderowej ślepocie i innych słabościach koncepcji aktywnej polityki społecznej. In: A. Kurowska, A. Wójtewicz, B. Pieliński, and R. Szarfenberg, eds., Perspektywa gender w polityce spolecznej. Toruń: Wydawnictwo Naukowe Uniwersytetu Mikołaja Kopernika.

Sztandar-Sztanderska, K. and Mandes, S., eds. (2015). Lokalna polityka społeczna. Polityka Spoleczna, thematic issue 17(1).

Szylko-Skoczny, M. (2004). Polityka społeczna wobec bezrobocia w Trzeciej Rzeczpospolitej. Warszawa: ASPRA-JR.

Trampczynski, B. (1973). Cooperatives of the disabled in Poland. International Labour Review 108(5), pp. 423-437.

Tymowski, M. (1971). Próba określenia minimum spożycia. Seria Opracowania i Materiały $\mathrm{nr}$ 72. Warszawa: Instytut Handlu Wewnętrznego.

van Gerven, M., Vanhercke, B., Gürocak, S. (2014). Policy learning, aid conditionality or domestic politics? The Europeanization of Dutch and Spanish activation policies through the European Social Fund. Journal of European Public Policy 21(4), pp. 509-527.

Verschraegen, G., Vanhercke, B., and Verpoortenand, R. (2011). The European Social Fund and domestic activation policies: Europeanization mechanisms. Journal of European Social Policy 21(1), pp. 55-72.

Warleigh-Lack, A. and Mccallion, M.S. (2012). 'Usages of Europe' and Europeanisation: evidence from the regionalisation of Sweden. Journal of European Integration 34(4), pp. 379-396.

Zieleńska, M. (2015). Mechanizmy reprodukcji i zmiany $w$ administracji publicznej na przykładzie wdrażania otwartej metody koordynacji. Warszawa: Scholar.

Zieleńska, M. (2018). The game of compliance: Polish anti-poverty policy and Europe 2020. In: M. Jessoula and I. Madama, eds., Fighting poverty and social exclusion in the EU: a chance in Europe 2020. London, New York: Routledge. 


\section{Polish hard and soft law}

\section{Hard law}

Act on Employment, 1989 (ustawa o zatrudnieniu)

Act on Employment and Counteracting Unemployment, 1994 (ustawa o zatrudnieniu i przeciwdziałaniu bezrobociu)

Act on Employment and Unemployment, 1991 (amendment to level of unemployment benefits, 1992)

Act on Family Allowances, 2003 (ustawa o świadczeniach rodzinnych)

Act on Promotion of Employment and Institutions of the Labour Market, 2004 (ustawa o promocji zatrudnienia i instytucjach rynku pracy) (amendment introducing socially useful jobs, 2005; amendment introducing activation and integration programme, 2014)

Act on Social Assistance, 1990, 2004 (ustawa o pomocy społecznej) (amendment introducing limited possibility of combining full wage and temporary benefit)

Act on Social Cooperatives, 2006 (ustawa o spółdzielniach socjalnych) (amendment raising the limits for non-excluded members, 2009)

Act on Social Employment, 2003 (ustawa o zatrudnieniu socjalnym)

Act on State Aid in Education of Children, 2016 (ustawa o pomocy państwa w wychowywaniu dzieci)

Directive on special programmes in counteracting unemployment, 1995 (rozporządzenie w sprawie programów przeciwdziałaniu bezrobociu)

\section{Hard law proposals}

Proposal of the act on social services delivery by social services centres, 2018 (projekt ustawy o realizacji usług społecznych przez centra usług społecznych)

Proposal of the act on principles of conducting social policy, 2007, 2008 (projekt ustawy o zasadach prowadzenia polityki społecznej)

Proposal of the act on social employment, 2003 (projekt ustawy o zatrudnieniu socjalnym)

\section{Polish and EU soft law (CSRs)}

Activation and Integration Programme - Directional Guidelines for Entities Organizing Activation and Integration Programme, 2016 (Program Aktywizacja i Integracja kierunkowe wytyczne dla podmiotów organizujących Program Aktywizacja i Integracja)

Country Specific Recommendations for Poland, 2012

Country Specific Recommendations for Poland, 2013

National Action Plan for Employment, 2018 (Krajowy Plan Działań na rzecz Zatrudnienia na rok 2018)

National Plan for Social Inclusion, 2004-2006 (Krajowy Plan na rzecz Integracji Społecznej)

National Programme of Counteracting Poverty and Social Exclusion. New Dimension of Active Integration, 2014 (Krajowy program przeciwdziałania ubóstwu i wykluczeniu społecznemu. Nowy wymiar aktywnej integracji) 
National Report 'Social Inclusion and Social Protection', 2006-2008 (Krajowy Program 'Zabezpieczenie społeczne i integracja społeczna')

National Social Integration Strategy, 2004-2010 (Narodowa Strategia Integracji Społecznej)

Operational Program Human Capital, 2007-2013 (Program Operacyjny Kapitał Ludzki) Strategy of Human Capital Development, 2013 (Strategia Rozwoju Kapitału Ludzkiego) Strategy of Responsible Development, 2016 (Strategia Odpowiedzialnego Rozwoju) 


\title{
Social inclusion and political participation of persons with disabilities in Slovakia
}

\author{
Alexandra Strážnická
}

\section{Introduction}

Because Slovakia is a contracting party of the UN Convention on the Rights of Persons with Disabilities (CRPD), the main purpose of this chapter is to illustrate how one of the international obligations arising from this international treaty is respected and followed in the legal regulation of the Slovak Republic and how its implementation affects the social inclusion and political participation of persons with disabilities in Slovakia. Article 29 of the CRPD (Participation in political and public life) is in play, according to which: 'States parties shall guarantee to persons with disabilities political rights and the opportunity to enjoy them on an equal basis with others.'

In my study, I start from the Priestley et al.'s (2016) perception of political participation as a broad definition grounded in human rights, encompassing individual and collective participation in the public sphere, and located within a context of multi-scalar governance from the global to the local. Political participation resources are distributed differentially among groups defined by socioeconomic status (ibid., 4), and Grammenos (2013) confirmed this by stating that despite compelling evidence that disabled people experience systematically higher risks of household poverty and social exclusion in terms of employment, education, relative income, and material deprivation, comparative studies have not included disability status as a variable. When researching political participation, disability equality should be considered along with other socioeconomic variables (ibid., 4-11).

Priestley et al. (2016) argue that in the case of disability we need to consider both 'access to' and the 'accessibility of' political activities for people with impairments (for wheelchair users, blind people, deaf people, people with cognitive impairments, etc.). Despite prominent non-discrimination legislation, some gaps may remain large, possibly due to the combined and interactive effects of polling place inaccessibility, social isolation, fewer economic resources, and perceptions that the political system is unresponsive. The political involvement of people with disabilities might greatly depend on the extent to which political elites attempt to address their political concerns (ibid., 2016, 6). 
The ambition of this chapter is to illustrate how and discuss why there are still several systematic and practical obstacles creating various disadvantages for people with disabilities in exercising their political rights. Searching for relevant information in respect to Slovakia, I found that there exist very few data related to the topic in question. The most comprehensive research data available are refer in particular to the right to vote. To illustrate the gap between the political rights granted by law and the abilities to exercise these rights in practice by persons with disabilities as concretely as possible, the chapter focuses on the analysis of this particular right.

Accessibility might mean different things for persons with varying disabilities. Because 'access to' and the 'accessibility of' political activities for persons with disabilities have to be taken into consideration, special attention will be paid to the aspects of 'access to and accessibility of' election communication, broadcasting, and of voting procedures in polling stations from both perspectives - first from the perspective of relevant duty-bearers (political parties, election authorities, etc.) and second from the perspective of the targeted group (persons with disabilities). The combination of both perspectives will provide a more comprehensive overview of the issue in question.

The methods used include collecting, selecting, and analysing relevant information and data. The research is based on a qualitative document analysis, including the Constitution of the Slovak Republic and relevant legal acts related to the topic being analysed, as well as relevant bibliographic, topic-focused, and/ or country-focused reports on the social inclusion and/or political participation of persons with disabilities, European and national policy papers, and the case law of the Slovak Constitutional Court.

The analysed data enable (i) an understanding of the recent state of affairs in the area of protection of rights of persons with disabilities in Slovakia, (ii) the identification of facilitators and barriers for effective exercise of the rights in question, and (iii) the formulation of conclusions and recommendations (see the last part of the chapter).

\section{Recognition of the special status of persons with disabilities in Slovakia framed in a historical context}

Slovakia (officially the Slovak Republic) is situated in Central Europe. In 1989, the Velvet Revolution peacefully ended communist rule in the former Czechoslovakia. Slovakia became an independent state on 1 January 1993, after the peaceful dissolution of Czechoslovakia, sometimes known as the Velvet Divorce. However, the political diffraction in the decades following has propelled drastic political swings and mixed priorities in the restructuring of political, economic, and social life of the country.

In Central Europe, the year 1989 variously marked the 'end of socialism' and a 'return to Europe'. It also signified among other things a desire for unity and 
common spaces of political security and economic integration. As Pickles (2010) points out, these desires might be mediated by geographical specificities, historical legacies, and complex processes of political and economic differentiation. In the context of the former Czechoslovakia, the 'return to Europe' was both a strategic claim to sustain the Velvet Revolution and a real belief that post-war collectivism had been an interruption of the natural historical development of the market, democracy, and civil society. The memories of lost inter-war economic growth led to a much fuller embrace of European integration and market deregulation in the former Czechoslovakia. As stated in Pickles' study (2010), from the political point of view the post-socialist period in Slovakia is marked by the return of socialist or social democratic parties to power through the electoral process (ibid., 132-134). In the progress of morphing towards a more deregulated liberal economy, elements of post-communist rule and social democratic influence further complicated systemic policy changes (Gould and Harris, 2012). Many of the liberal principles of increasing economic growth in the private sector were established in response to the welfare policies of the first elected premier of the new Slovak government, Vladimír Mečiar. Mečiar developed a negative public image when the government maintained flawed policy from the communist system and further stunted economic growth during a period of high political corruption (Fisher et al., 2007). The growing influence of neoliberalism in Slovak governance is entwined with the restructuring of the welfare state. Since the initial economically driven policy push of the centre-right government in 2002, Slovakia has embraced a more neoliberal approach to its welfare-state policies. Left-wing and right-wing parties alike in post-communist countries have largely supported deregulating private markets and decreasing government expenditures (Gould and Harris, 2012).

The year 2004 is generally considered as one of the most significant markers of post-1989 transitions in Central and Eastern Europe, when the first group of post-socialist states was admitted into the EU (European Union) (Poland, the Czech Republic, Slovakia, Hungary, Estonia, Latvia, Lithuania, and Slovenia). For some it also marked the end, in practice, of 'post-socialism' as a discursive strategy for dealing with transformation in favour of harmonization and integration. The period prior to 2004 was devoted to meeting the requirements of the acquis communautaire in terms of dealing with issues of institutional transparency, legal and regulatory frameworks, and forms of governance (Pickles, 2010, 135-136). In March 2000 at the European Council in Lisbon, countries wishing to join the EU were pressed to adopt policies that had 'decisive impact on the eradication of poverty' (European Council, 2000, Section 32). Slovakia - at that time a candidate state for EU membership - participated in the meeting and received guidance for implementing economic and social policies promoting the inclusion of disadvantaged groups. The social inclusion might be understood very generally as a process of improving the ability, opportunity, and dignity of vulnerable and disadvantaged groups of the population within society (Džambazovič and Gerbery, 2005, 144-146; 2011, 132). Persons with 
disabilities are only one of various and different vulnerable and disadvantaged groups of a population. As Grammenos (2013) noted, persons with disabilities experience systematically higher risk of household poverty and social exclusion in various spheres of their lives (ibid., 4-10).

To frame the recent developments in the EU social inclusion agenda focused on the position of persons with disabilities, it is important to briefly refer to the Europe 2020 Agenda and the European Disability Strategy 2010-2020. The Europe 2020 Agenda is a new strategy for the EU to develop as a smarter, knowledge-based, greener economy delivering high levels of employment, productivity, and social cohesion. The European Disability Strategy 2010-2020 is a comprehensive framework committing the Commission to the empowerment of people with disabilities to enjoy their full rights and to removing everyday barriers in life. The Strategy builds on the UN CRPD and takes into account the experience of the Disability Action Plan 2004-2010 (ibid., 2013, 12-13).

As stated in Repková et al.'s report (2011), the national regulations and policies dealing with social protection and social inclusion of persons with disabilities are divided into two groups. The first group is focused on a 'mainstreaming policy' approach and is reflected in the 2004-2006 National Action Plan of Social Inclusion aimed at all groups of persons who are at risk of poverty and social exclusion. Persons with disabilities are considered to be persons at high risk of poverty and social exclusion, especially persons with high-level disabilities who are dependent on long-term care. Measures to increase the social inclusion of disabled persons and their families are focused on increasing their employability, supporting their income situation through the compensation system, ensuring an integrative social approach to long-term care for dependent persons, ensuring a barrier-free public environment (access to post-offices, hospitals, schools, leisure-time facilities, etc.), encouraging family solidarity by facilitation of family caregivers, and supporting Internet and computer literacy. The second group of documents dealing with measures focused especially on persons with disabilities in all living areas is considered to consist of 'targeted policies'. The National Programme on Development of Living Conditions for Persons with Disabilities in all Living Areas (2001) includes education, transport, employment, family life, healthcare, access to social services, leisure-time, environment, and income support as well as political, social, and cultural participation (ibid., 2).

Besides the official 'state-based approach', a so-called civic-society approach is noticeable in Slovakia. Priestley et al. (2016) refer to the findings of the research carried out in the United Kingdom that drew attention to the specific barriers facing people with intellectual impairments and the importance of social capital and networks of support as enablers of political participation, and they point out that these findings suggest that establishing political rights and providing accessibility might not be sufficient to achieve full participation without also engaging proactively with disabled people in civil society and with their political claims. Civil society organizations foster new forms of political participation 
that do not exclude persons with disabilities, and outreach policies of disability organizations can play a large role in creating conditions that encourage political participation by disabled persons (ibid., 5-7).

A huge number of civic society organizations in the disability field have emerged in Slovakia since the political and economic transformation in the 1990s. In 2008, the Ministry of the Interior registered almost 750 such organizations. On the other hand, only 21 of them gained the status of 'organisation with confirmed activities'. Repková et al. (2013) described the situation as a 'wild development of a civic society' accompanied by two contradictory phenomena: (1) the extensive rise of the number of organizations leading to fragmentation of the civic society movement in the disability sector, and (2) the poor preparation of the majority of such organizations for meeting their original functions and responsibilities. Such development has mirrored how the whole of civic society has been re/developed since the turn of the millennium in Slovakia (ibid., 4).

\section{Notions of 'disability'}

To talk about the situation of persons with disabilities in Slovakia, it is indispensable to explain who is considered to be 'disabled'. There is no unified definition of 'disability' in the Slovak legal system, but Slovakia has accepted the term 'persons with disabilities' as those who have long-term mental, physical, or other disabilities that prevent them from being integrated into society on an equal basis with others.

The decisive point for disability assessment is the so-called functional disorder or functional defect level. A functional disorder is the lack of physical, sensory, or mental capacities in an individual, which in view of the expected development of the disability concerned will last for more than 12 months. There are two notions of disability used with regard to the level of functional disorder of a person, namely disability/invalidity and severe disability. A person is considered as disabled/invalid if, due to his/her long-term unfavourable health condition, his/her ability to perform gainful activity is reduced by more than 40 per cent compared to that of a healthy person. Severe disability is a disability involving a functional disorder of at least 50 per cent (Central Office of Labour, Social Affairs and Family, 2018).

Medical assessments are carried out by the medical assessor of the relevant branch of the Social Insurance Agency and by the medical assessor at the headquarters of the Social Insurance Agency (European Commission, 2018, 16-18).

Based on the findings concerning the perception of persons with disabilities in the Slovak society, common people feel that persons with disabilities are in different living situations and contexts in disadvantaged/unequal positions, but it is difficult to obtain evidence about direct discriminatory practices of employers, service providers, or public authorities (Repková et al., 2011,4). 


\section{Exercise of civil and political rights by persons with disabilities}

In modern democracies, civil and political rights are guaranteed equally to all citizens, even people with disabilities. There are several pillars in the Slovak legislation that guarantee the civil and political rights of persons with disabilities, and these are constituted in a generic pattern as a natural part of the political and participative rights of the entire adult population. The framework is built as a combination of a generic legal framework with some affirmative provisions focused particularly on persons with disabilities (Repková et al., 2013,2).

The principle of equal treatment, or prohibition against discrimination, is guaranteed in Article 12 of the Constitution of the Slovak Republic:

Fundamental rights shall be guaranteed in the Slovak Republic to everyone regardless of sex, race, colour, language, belief and religion, political affiliation or other conviction, national or social origin, nationality or ethnic origin, property, descent or any other status. No one shall be aggrieved, discriminated against or favoured on any of these grounds.

The Slovak Constitution constitutes a set of general political rights - the right to vote, right to stand for political and public office, freedom of expression, the right to information, the right to assemble and to set up associations, and the right to petition.

In the legal framework, civil and political rights are guaranteed for all, and nobody shall be discriminated against on any of the protected grounds, including disability. Although persons with disabilities are by no means excluded from being subjects of civil and political rights, they might face certain barriers in exercising these rights, especially in terms of practical restrictions and the lack of awareness among relevant authorities on necessary and reasonable adjustments to ensure accessibility of political activities and participation in public life. In order to demonstrate this statement - the right to vote will be analysed from a constitutional, legal, and practical perspective because the research data that are available concentrate especially on aspects of this particular political right.

\section{Voting rights regulation}

Voting rights are regulated in several legal norms:

- Act No. 346/1990 Coll. on Election to the Local Self-government Bodies

- Act No. 46/1999 Coll. on Presidential Elections

- Act No. 303/2001 Coll. on Election to Regional Governments

- Act No. 331/2003 on Election to the European Parliament

- Act No. 333/2004 Coll. on Elections for the National Parliament

- Act No. 180/2014 Coll. on Conditions to Exercise Voting Rights 
Each of the cited Acts has been adopted and has come into legal force at different times, and this has led to different rules related to the exercise of voting rights by persons with disabilities. A special rule concerns a barrier to exercise one's voting right in regard to the legal capacity of the person concerned. According to the Act on Election to Local Self-government Bodies, the limitation or deprivation of legal capacity prevents a person from exercising his/her right to vote. Partially different legal requirements are in place for elections to the European and National Parliament and to the Regional governments. In these instances, a person is prevented from exercising his/her voting right only if he/ she is totally deprived of his/her legal capacity. There is no restriction with regard to a person's legal capacity pursuant to the Act on Presidential Elections (Repková et al., 2013, 10).

\section{Deprivation or restriction of legal capacity}

The denial of disabled people's voting rights has drawn attention in the past, notably in the denial of rights to people with intellectual or psychosocial impairments that are perceived to affect their mental capacity. Disabled people deprived of legal capacity also had no direct access to redress if their voting rights were infringed. Slovakia is among those EU member states where a person would first have to challenge the decision on their legal capacity in order to then seek redress for deprivation of their right to vote (Priestley et al., 2016, 14-15).

There were several initiatives to tackle the exclusion of people with intellectual disabilities from the right to vote. With regard to the obligations of the Slovak Republic to comply with the international standards in various international human rights treaties that were signed and ratified by the Slovak Republic (especially the UN CRPD) and with the decision of the Constitutional Court of the Slovak Republic (hereinafter referred to as the 'Court'), the concept of legal capacity has been completely redefined during the recodification process of civil law in Slovakia in recent years.

In Judgment No. I. ÚS 313/2012-52 of 28 November 2012, the Court remarked that present-day professionals observe disability differently in comparison to the past. Disability is not understood merely in a medical sense but it is being set in a social and legal framework that integrates the values that form the core of human rights, such as human dignity. Within the bounds of the constitutional dimension of human rights, the deprivation/limitation of legal capacity ex constitutione pursues primarily the interest of the person concerned and only consequently the public interest or the interest of third persons. The Court expressed its regret that the public interest is being given precedence, even at present, to the detriment of the person concerned. Deprivation of legal capacity means 'legal death' of the person concerned, and it should be viewed as ultima ratio. Deprivation should be considered only if the application or implementation of less repressive means is excluded or ineffective. Complete deprivation is equally out of the question when the disabled person concerned demonstrates at 
least partial capacity. General courts are obligated to consider it ex officio, but even more so if the parties explicitly requested it. In other words, if the mental illness does not entirely prevent the person from acting within the law, the courts should order the limitation of the capacity and not its deprivation (Constitutional Court of the Slovak Republic, 2012).

The Court's reference might be interpreted that a diagnosis of permanent mental illness by an expert does not suffice in order to deprive a person of legal capacity. It is necessary that courts find other evidence of the permanent mental disability that completely precludes the person concerned from carrying out any legal acts. The Court must also reflect on the possible violation of human rights that are guaranteed by international treaties (Chládeková, 2013, 561-566).

In May 2015, the National Council of the Slovak Republic adopted a proposal for three new codes replacing the previous Act on Civil Proceedings. Since 1 July 2016, the former Act on Civil Proceedings has been replaced by three separate codes, namely the Rules of Civil Contentious Litigation (RCCL), the Rules of Civil Non-contentious Litigation (RCNCL), and the Code of Judicial Review of Administrative Decisions (CJRAD).

In terms of protection of the rights of persons with disabilities with regard to deprivation of legal capacity, the Act on Rules of Civil Non-contentious Litigation is of a particular importance. According to the new provisions, there are only the following procedures concerning legal capacity: a limitation of legal capacity to legal acts, a change of limitation of legal capacity to legal acts, and a re-granting of legal capacity to legal acts to a natural person. Efforts of the recodification committee to develop a more precise elaboration of requirements for the procedure concerning legal capacity are also visible from further regulations of this procedure. Actions to start a proceeding have to contain - in addition to the general requisites of the proceeding - a description of the evidence justifying the intervention into the individual's legal capacity and the reason that less-restricting action is not possible, and a description of the evidence justifying the change in the restriction of the individual's capacity to legal acts, or of evidence justifying the return of the individual's capacity to legal acts. The parties in the proceedings are a plaintiff and the person whose legal capacity is being determined. A close person or a person who can prove a legal interest can suggest that the court should include him or her as a party of the proceedings. The person whose legal capacity is being determined has the capacity to act fully independently in the court.

\section{Access to and accessibility of voting and elections from the perspective of the responsible authorities}

Election administration is delegated to election commissions that consist of the nominees of the political parties competing in elections. The competencies of all election commissions for a given type of election (local, regional, national, presidential, European) are the same. Guidelines on the accessibility of voting for people with disabilities are set in the cited voting acts, and they are the same 
for all types of elections. In Slovakia it is not possible to provide continuing education of election commission members because the composition of the election commission is different each time. According to the statement of the Ministry of the Interior, before any election the election commission members at all levels must attend training on how to apply voting and election legislation in practice (Repková et al., 2013, 12).

Political parties in the EU operate independently of the state, and they are not subject directly to the global disability governance framework, but states do have obligations under Article 29 CRPD. It is obvious that the concept of political participation has been expanded to include, for example, attending meetings, signing petitions, or activism in political protests and new social movements. For persons with disabilities, accessibility to the physical environment is necessary for equal participation in public life (Priestley et al., 2016, 17-25).

The most important code regulating the activities of political parties in Slovakia was passed in 2005. All documents regulating the positions, programmes, and activities of any political party have to be in compliance with the Slovak Constitution, constitutional and legal norms, and obligations from international treaties signed and ratified by the Slovak Republic. There are no special requirements related to persons with disabilities.

The standard accessibility rules for each newly constructed building are regulated in a separate act from 1976, and all public and private bodies (including political parties) have to follow them. On the other hand, the legal regulation on Internet and computer technology accessibility standards is compulsory only for public sector institutions, meaning that political parties are not subject to these standards. This leads to a situation in which political parties are in general not obliged to make their manifestos, programmes, application forms, or websites accessible for people with visual or hearing impairment. However, if invited and providing space for presentations, political parties are usually willing to present and inform about their intentions and programmes related to the improvement of living conditions of persons with disabilities.

In relation to the flash survey of Repková et al., (2013) in the ANED Report 2013, two of six political parties present in the parliament responded in terms of accessibility that there are no internal rules going beyond legal requirements and that the issue as such remains unaddressed. In particular, a representative of the political party stated that they have no regulations to ensure accessibility, nor do they consider these issues in the planning of activities. In practice, they claim, many of their activities take place in buildings that are accessible, including the barrier-free building where the party has its headquarters. Regarding their opinion towards the potential introduction of legally binding accessibility requirements for political parties, the representatives of the political parties in question referred to the mechanism of enforcement and sanctions. In general, it was stated that requirements in this area should be reasonable with regard to the expenses that political parties would have to bear in order to comply with the requirements. When asked to estimate the number of its members with 
disabilities (holding an office within the party), the response was that the data were not available because they do not record that (ibid., 14).

There are no additional legal requirements for accessibility that would be binding for holders of public office based on the sole fact of their status. Thus, despite the fact that there are general rules requiring, for example, accessibility of each newly (re)constructed building, no legal norm at the national level imposes a duty on holders of public office to hold meetings in venues that are accessible. However, even these general legal obligations seem to have had a definite impact on accessibility in practice. One example of a proactive approach is that most of the briefings of the Slovak prime minister in 2010-2012, especially those broadcast by television, were simultaneously interpreted into sign language without any legal obligation to do so. In order to gain more evidence on potential voluntary action as well as accessibility practice among public office holders, Repková et al. (2013) conducted a flash survey addressing the Office of the National Council of the Slovak Republic and eight offices of the self-governing regions. These bodies are inter alia responsible for providing assistance to members of the national/ regional parliaments in all areas, including on accessibility. The survey found that neither the Office of the National Council nor any of the regional offices have an internal written statement on how to ensure accessibility for citizens with disabilities. However, each of them confirmed their compliance with legal obligations regarding physical accessibility, and they also declared their readiness and flexibility to ensure equal opportunities in cases of such requests (ibid., 15-16).

There are no special legal requirements concerning the situation if an office holder is a person with disability. At the same time, as shown by the flash survey, neither the Office of the National Council nor any of the regional offices have a written document regulating this area. The Office of the National Council has had specific experience with ensuring accessibility for an elected official. In the election term 2002-2006, one of the members of the parliament was a wheelchair user. At that time, accessibility of the building was ensured. At the regional level, since its introduction in 2001, none of the regions responding to the survey has had a member of parliament with a disability. One of the regional offices stated that at the beginning of each election term, they themselves contact each member of parliament to find out their needs for adjustments, e.g. special dietary requirements. Otherwise, all eight regional offices declared themselves ready to provide reasonable accommodations. As for financial costs, these would be part of the budget of a region, but these seem to have no importance when adopting reasonable accommodations (ibid., 16-17).

\section{Access to and accessibility of elections communication and broadcasting from the perspective of persons with disabilities}

From the majority population's point of view, election broadcasting during election campaigns does not seem to be problematic. However, the current legislation 
does not set out any legal obligation that the election procedure is available to all eligible voters (Strážnická, 2016, 9-11). People with visual or hearing impairment have limited access to information if it is not translated into Braille script or sign language. Consequently they have limited opportunities to follow political debates, to familiarize themselves with the programme of political parties, or to familiarize themselves with the competences and moral standing of the candidates and to make their own choice whom to vote for. Despite some good examples, in general it is far from common practice that political debates on television are interpreted into sign language. Likewise, there are no statistics concerning other forms of accessibility of election broadcasting, e.g. via the Internet. There are apparent limits in accessibility of election broadcasting in terms of legal requirements and common practice (Ondrušová et al., 2014, 24-28).

In practice there is a general impression that elections are gradually becoming more accessible. Occasionally there have been some efforts directly targeted at persons with disabilities to communicate information on the election in Braille and audio-recorded formats. Formally, the section responsible for elections and referendums at the Ministry of the Interior of the Slovak Republic orders the production of such material. The Slovak Library for the Blind usually starts negotiations in advance in order to include this activity in the election budget. The candidate lists are distributed to all subscribers to journals for the blind, which are also produced by the library. In addition, the lists are available at each of the eight regional offices of the Slovak Blind and Partially Sighted Union, the biggest organization of people with visual impairment in Slovakia. The lists in alternative formats are not used directly at the elections; rather, they are complements to a procedure in which a citizen with a visual impairment is delivered candidate lists by e-mail in advance in order to familiarize him/her with the candidates' profiles and to make an informed choice (Repková et al., 2013, 24-28).

\section{Accessibility of voting procedures}

The mainstream way of voting is to come to the official polling station in the election administrative area, fill in the ballot, put it in the envelope, and put the envelope into the ballot box in the official polling station. However, this way of voting might not be easily available for all eligible voters, especially for persons with disabilities.

Therefore the legislation sets two alternatives for those who cannot vote in polling stations: (1) a regular e-mail or (2) a mobile ballot box system. Voting by regular e-mail is designed only for citizens living outside the country. A mobile ballot box system is available for those who cannot come to the polling stations due to serious health problems or physical inaccessibility of a building in which the polling station is situated. As an example, a voter who is a wheelchair user might ask for voting through the mobile ballot box. In such a case, the members of the election commission come to the voter's home and enable him/ her to vote. According to the statement of the Ministry of the Interior, the voter 
may ask the municipality to be able to vote through the mobile ballot box in advance or just on the day of elections with the help of the competent local election commission. Coming back with the mobile ballot box, the members of the election commission will mark the voter's serial number in the list of voters. However, they are not obliged to keep a special register of voting through the mobile ballot box. As a result, it is technically possible to know the numbers of voters using this means of voting, but in practice this is not done. Therefore it is hard to estimate the participation rate of people with serious health problems in the elections. Voters who themselves cannot read or write and who cannot fill in the ballot are granted the right to be accompanied by another voter in a special voting space. This assistant is allowed to fill in the ballot according to the instructions of the voter with a disability or of an illiterate voter and put it into the envelope. If the voter is not able to put the envelope into the ballot box due to his/her disability, he/she can ask another voter to do it in his/her presence. For such assistance, approval of the election commission is not required. The only restriction is that the assisting voter cannot be a member of the local election commission (Ondrušová et al., 2014, 24-28).

People living in institutions have political rights, including the right to vote, on an equal basis to other people, and there are some supportive measures for the practical enforcement of voting rights for people living in residential care. In order to increase the motivation of people living in residential care to participate in elections, institutions organize, in cooperation with political candidates or others engaged in political issues at different levels, debates and meetings located in these institutions (Repková et al., 2013, 10-11). In practice, people living in residential care usually vote through the mobile ballot box. After delivering voting cards for individuals living in an institution from the local authorities where the individuals have their permanent residence, institutional service providers ask the relevant election authority to provide a mobile ballot box. The residential voters then put their ballots into this box. The option to vote in an official polling station corresponding to the permanent residence of an individual residential voter is not necessarily avoided. To apply this option, the residential caregivers rely on the assistance of the resident's family members. A particular problem related to regional elections has been raised, and this refers to a situation in which relevant election authorities refuse to ensure the possibility of using a mobile ballot box due to a residential voter having a permanent address that is different from that of the institution in which the voter is living (Priestley et al., 2016, 15).

\section{Policy options for improving access to the exercise of civil and political rights by persons with disabilities}

Up to one quarter of the European electorate identify themselves as having some kind of impairment or long-term health condition that affects their daily activities 
(some 80 million people). Disabled people are a very significant constituency in European countries, growing with demographic ageing, and their concerns are those that any political party or candidate seeking election should be mindful of. To ensure that rights become a reality, states need to raise the awareness of all stakeholders in the political process. Raising disability awareness in general is a CRPD obligation (Article 8) as is ensuring participation in cultural life, including the mass media (Article 30). More specifically, electoral authorities need to be better informed on disability equality in order to monitor outcomes and to ensure that officials are briefed on reasonable adjustments and accessibility for disabled voters. However, it has been suggested that establishing political rights and providing accessibility might not be sufficient to achieve full participation without also engaging proactively with disabled people in civil society and with their political claims (Priestley et al., 2016, 26-27).

According to Repková et al. (2011), the formal legal regulations of measures for improving living conditions for persons with disabilities reflected in the state policies have been well prepared. The real problem is their implementation in practice (primarily in small cities and in economically poorer and rural areas) and the cooperation of different types of stakeholders having direct or indirect responsibilities in the field (ibid., 2-4). There are two proposed options for improvement the accessibility and effective exercise of civil and political rights by persons with disabilities, discussed in the following section.

\section{'Top-down' approach and 'Bottom-up' approach}

Implementation of the 'top-down' option would, in the above-mentioned context, include preparation of recommendations and guidelines for all relevant authorities at the central level for various situations related to the position of persons with disabilities in cooperation with representatives of associations defending the rights of these populations (e.g. the Slovak Disability Council, the Committee for Persons with Disabilities of the Governmental Council for Human Rights, and Government Council of the Slovak Republic for Human Rights, National Minorities and Gender Equality). The advantage of the universal approach and of general guidelines adopted at the central level is that there are common principles and procedures for the same situation across the whole country. On the other hand, this approach does not take into account regional specificities or differences that contribute to gaps in terms of the quality and effectiveness of the exercise of the civil and political rights of persons with disabilities. At the same time, the 'top-down' approach would in some cases disregard the current procedures applied by various public bodies in the field of accessibility of rights or it would decrease their effects (Kešelová et al., 2014, 29-30).

The 'bottom-up' approach is based on the principle of subsidiarity and recognizes the specific needs of the institutions responsible for the accessibility of procedures (the competence and experience of a district office, election commission, political party, etc.). Such an option might be appropriate in cases in 
which public bodies already have some experience in the field of promotion of rights of persons with disabilities and are able to respond to their special needs. However, as the flash surveys of Kešelová et al. (2014) show, Slovak institutions lack this kind of experience. According to the cited researchers, it would be a clear risk to rely only on one of the described approaches. As stated in the policy paper, follow-up research is required. With regard to the current state of affairs, there would be a preference for the 'top-down' option based on the network of all relevant stakeholders sharing their best practices with regard to the accessibility of rights of persons with disabilities (ibid., 30-31).

\section{Main findings and conclusions}

In Slovakia, there are hardly any data available on the impact of disability on the participation of persons with disabilities in public and political life. The exercise of the right to vote is a special demonstration of personal identity and is an expression of personal opinion. Particular elements of the right to vote have been researched and analysed most comprehensively in the framework of political rights in the sources referred to in this chapter. Therefore, special attention has been paid to the aspects of 'access to and accessibility of' election communication, broadcasting, and voting procedures in polling stations from the perspective of responsible duty-bearers as well as of the persons with disabilities.

Based on the provided analysis, the following barriers and facilitators for the proper exercise of political rights (including the right to vote) might be indicated:

Special right to vote-related barriers: lack of continuing education of election commission members; performance of only ad hoc training of election commission members before a particular election; lack of legally binding regulations on accessibility requirements for political parties and other private bodies with respect to their activities; insufficient participation of civic organizations for the promotion of the rights of persons with disabilities in public life.

Barriers related generally to political rights: persons with disabilities experience structural and status injustices because they are placed in a position of social subordination preventing them from full participation in various aspects of their lives. This might be partially explained by the fact that Slovakia, as a postsocialist country, has engaged in neoliberal political and economic reforms. Implementation of social inclusion policies has been inter alia marked by a hybrid model of a welfare system embracing elements of both social democracy and neoliberalism (Gould and Harris, 2012).

Another obstacle in reaching a progressive realization of political rights of persons with disabilities is the fact that there are still insufficient data concerning various aspects of disabled persons' social lives and political participation. The data collection is not performed systematically, and therefore there is still a lack of evidence on barriers, facilitators, and participation of these people in political activities and in governance. Based on the findings of the authors of the ANED country reports, it might be noted that the limitations and barriers in exercising 
their rights may be caused also by a limited demand for improvements. Most of the relevant stakeholders have rarely, if ever, received a request to make certain adaptations in relation to specific needs on the grounds of disability. This is also due to the fact that persons with disabilities, as a relatively minor group of the population, are not able to defend their rights at each venue separately.

Facilitators for the promotion of political rights (including the right to vote): with regard to the ongoing adaptation and implementation of the EU social inclusion policies, Slovakia has to act in compliance with the outcomes highlighted in the Report on Implementation of the European Disability Strategy by the European Parliament in October 2017, including the participation aspect for persons with disabilities (European Parliament, 2017). The recently adopted National Program on Improving Living Conditions for Persons with Disabilities for the Years 2014-2020 formally covers all relevant areas.

An important milestone to enhance the protection of the rights of disabled persons in Slovakia, arising from the CRPD, is the establishment of the Office of the Commissioner for People with Disabilities, which constitutes a new type of legal institution providing a considerable range of social and legal services, in particular with regard to the application, guaranteeing, and respecting of fundamental human rights and freedoms of persons with disabilities.

After identifying some of the barriers and facilitators for the progressive realization and effective exercise of political rights by persons with disabilities, the following recommendations might be formulated:

- To adopt and distribute guidelines ensuring regular education of election commission members with regard to the special needs of persons with disabilities during the election by the Ministry of the Interior and the relevant subordinate bodies.

- To make the public more sensitive to issues regarding the protection of the rights of persons with disabilities and their special needs via the support of civic organizations in this field and via the incorporation of disability and non-discrimination related topics into the school citizenship curricula.

- To monitor the political participation of persons with disabilities in order to provide equal opportunities for exercising civil and political rights.

- To adopt regulations in the form of legal obligations for political parties, the press, and broadcasters to perform their activities in accessible forms for persons with disabilities in order to enable them to fully participate in public life.

The supportive measures might include legal amendments, awareness-raising campaigns, and/or increased funding. This non-exhaustive list of possible supportive measures reflects the current challenges of the ongoing process of improving the quality of life and the effective exercise of the fundamental rights and freedoms of persons with disabilities in Slovakia. 


\section{References}

Central Office of Labour, Social Affairs and Family (2018). Severe Disability (available at: www.upsvr.gov.sk/socialne-veci-a-rodina/tazko-zdravotne-postihnuti.html?page_ $\mathrm{id}=231$ ).

Chládeková, M. (2013). Slovak constitutional court: deprivation of legal capacity due to mental illness - a legacy of the past? International Constitutional Law Journal 7(4), pp. 561-566.

Constitutional Court of the Slovak Republic (2012). Decision No. I ÚS 313/2012-52 (28.11.2012), Collection of Findings and Ruling of the Constitutional Court (available at: www.ustavnysud.sk/vyhladavanie-rozhodnuti\#!DecisionsSearchResultView).

Džambazovič, R. and Gerbery, D. (2005). Od chudoby k sociálnemu vylúčeniu, Sociológia 37(2), Bratislava: Comenius University, pp. 143-176.

Džambazovič, R. and Gerbery, D. (2011). Inovativne orientácie v sociálnej politike-perspektíva sociálnej inklúzie. Bratislava: Comenius University, pp. 1-132 (available at: https://fphil.uniba.sk/fileadmin/fif/veda/centra_ex_akad_siete/cesiuk/socialna_dimenzia/ Monografie_Gerbery_Dzambazovic.pdf).

European Commission (2018). Your security rights in Slovakia. Brussels: DirectorateGeneral for Employment, Social Affairs and Inclusion (available at: ec.europa.eu/ social/BlobServlet?docId=13773\&langId=en).

European Council (2000). Presidency Conclusions. Lisbon: European Parliament (available at: www.europarl.europa.eu/summits/lis1_en.htm).

European Parliament (2017). Report on the Implementation of the European Disability Strategy (available at: www.europarl.europa.eu/sides/getDoc.do?pubRef=-//EP// TEXT+REPORT+A8-2017-0339+0+DOC+XML+V0//EN\&language=en).

Fisher, S., Gould, J., and Haughton, T. (2007). Slovakia's neoliberal turn. Europe-Asia Studies 59(6), pp. 977-998.

Gould, R. and Harris, P.S. (2012). Welfare reform and disability in Slovakia: exploring neoliberalism, social justice and employment policy, Disability Studies Quarterly (DSQ) 32(2) (available at: http://dsq-sds.org/article/view/3200/3071).

Grammenos, S. (2013). European comparative data on Europe 2020 \& people with disabilities. Academic Network of European Disability Experts (ANED), Cornell University, ILR School (available at: https://digitalcommons.ilr.cornell.edu/cgi/viewcontent.c gi? article $=1569 \&$ context $=$ gladnetcollect $)$.

Ondrušová, D., Kešel’ová, D., and Repková, K. (2014). Civil and political rights of persons with disabilities - Current state and challenges. Policy paper - Bratislava: Institute for Labour and Family Research, IVRP1/2014, pp. 1-70.

Pickles, J. (2010). The spirit of post-socialism: common spaces and the production of diversity. European Urban and Regional Studies 17(2), pp. 127-140 (available at: http:// citeseerx.ist.psu.edu/viewdoc/download?doi=10.1.1.912.5228\&rep=rep1\&type=pdf).

Priestley, M., Stickings, M., Loja, E. et al. (2016). The political participation of disabled people in Europe: rights, accessibility and representation. Electoral Studies 42, pp. 1-9.

Repková, K., Hanzelová, E., and Brichtová, L. (2011). Report on the social inclusion and social protection of disabled people in European countries - Slovakia. Academic Network of European Disability Experts (ANED), University of Leeds, UK (available at: www.disability-europe.net/country/slovakia).

Repková, K., Kešel'ová, D., and Ondrušová, D. (2013). Country reports on citizenship and political participation - Slovakia. Academic Network of European Disability 
Experts (ANED), University of Leeds, UK (available at: www.disability-europe.net/ country/slovakia).

Strážnická, A. (2016). Accessibility of rights for people with disabilities, Human Rights News 4(3), pp. 9-11 (available at: http://fses.uniba.sk/fileadmin/fsev/o_fakulte/ dokumenty/HRN/Human_Rights_News_ENG_3-2016_prac.pdf). 


\title{
Social economy entities as a practical instrument to enhance social inclusion in Poland
}

\author{
Urszula Bronisz, Andrzej Jakubowski, \\ Magdalena Miszczuk, and Andrzej Miszczuk
}

\section{Introduction}

Social economy is a multi-dimensional concept that is variously defined and understood. In the last decade a resurgence of social economy values was observed, especially in new market sectors associated with welfare services. In Europe, the social economy is commonly perceived as a 'third sector', understood as the ensemble of non-profit organizations with a democratic structure, not-for-profit private enterprises, and private enterprises with social aims (Nicholls, 2006), and the role and importance of the social economy in attaining both the Lisbon Strategy and Europa 2020 objectives of sustainable growth and full employment have been emphasized by European institutions (European Parliament, 2008; European Commission, 2011). Despite the growing economic and political relevance of the social economy, there is still a lack of a universally accepted definition of this notion. The diversity of national economic structures, cultural traditions, legal frameworks, and roles played by the social economy in European Union (EU) member states makes the comparison and assessment of the size and impact of social capital a real challenge. However, despite the difficulty in defining the concept, J. Defourny, P. Develtere, and B. Fonteneau (Defourny et al., 1999) recognized specific features for social economy entities, namely autonomic management, democratic decision-making processes, precedence of providing services to members or community over profit, and primacy of people and labour over capital during profit sharing. The visible increase in the importance of the social economy sector led to the emergence of the notion of social investment. This concept refers to different kinds of social entities like community organizations, charities or non-profits, social enterprises, and social business, but the key is that they engage private investment to contribute to the public benefit (Wilson, 2014). The approach to the social economy among EU countries is diverse, but in general they can be assigned to three groups. The first comprises countries like France, Spain, Greece, and Portugal, in which the concept of social economy is widely accepted and finds firm recognition by public authorities and researchers. The second group includes countries like Poland, Italy, Denmark, and Malta in which the concept enjoys a moderate level 
of acceptance and coexists alongside other concepts such as the non-profit sector, the voluntary sector, and social enterprises. Finally, the last group includes countries like Austria, Germany, Hungary, and Slovakia where there is little or no recognition of the concept of social economy (Monzon and Chaves, 2012).

In Poland, the social economy is understood to be an economic activity including both social and economic objectives, and the idea has a fairly long tradition dating back to the partition period. The revival of the social economy sector took place after the political transformation and collapse of communism, but its more dynamic and structural changes have been related to the Polish accession to the European Union in 2004.

Poland has 16 regions that correspond to the EU NUTS (Nomenclature of Territorial Units for Statistics) II level. The existence of territorial disparities results from infrastructural gaps, low productivity and innovation, and a failure to adjust the social and economic structure to development needs. Therefore, to prevent the risk of marginalization and to counteract the problems of regional unemployment while simultaneously increasing human and social capital development and improving access to the labour market, the solutions of EU social economy policy were implemented. This was associated with overcoming the structural, institutional, and financial barriers, and problems related to the insufficient cooperation of non-governmental organizations with local governments. Incorporating the purposes of the social economy into the framework of cohesion policy resulted in many changes to the Polish legal system in addition to the development of strategic documents for the development of social enterprises, both at the national and regional level. Financial support from the Human Capital Operational Programme, co-financed by the European Social Fund, contributed to promoting the idea of social entrepreneurship and the creation of new social economy entities.

Poland's accession to European structures has influenced the change of the social policy programming model. One of the important issues became the construction of a system to strengthen the social economy sector. On the basis of the structural funds, the existing entities were supported, and assistance was provided for the creation of new ones, with the majority of measures being implemented at the regional level. As part of the undertaken actions, the provisions concerning the social economy sector were amended, and the adopted strategic documents underlined the importance of the social economy as an important tool combining pro-development activities with actions for social cohesion. The transformations in the legislative sphere have influenced the increase in the activity of social economy entities, and have also enabled the development of new organizational and legal forms of the social economy.

The main purpose of this chapter is to analyse the role of the social economy entities in promoting social inclusion and in solving the socioeconomic problems in Poland since joining the European Union, in particular in the programming period 2007-2013. The chapter is divided into three main sections. In the first section the concept of the Polish model of the social economy is described. In 
the second the spatial structure of social entities in Poland is presented. In the third section an empirical study concerning the correlation between the development of the social economy entities, the availability of EU funds, and the intensity of social problems is included, and finally a short conclusion summarizes the findings.

\section{Polish model of the social economy}

The social economy is one of the essential elements of Polish social policy, and Polish traditions in the field of social economics date back to the early nineteenth century. At the end of that century in particular, partitions were created whose dominant goal was combating alcoholism and promoting hygiene (the Russian and Austrian partitions) and supporting entrepreneurship (the Prussian partition). In the interwar period, many social economy entities focused on social integration appeared after 123 years of partitions. An important role in this respect was played by the Act of 29 October 1920 on cooperatives (Journal of Laws of 1920, No. 111, item 733), which was in force until 1961. The period of real socialism (1945-1989) caused the decline of social economy organizations both in Poland and in other countries of the region under the control of the communist authorities. The legal and economic status of social economy entities was considerably eroded. Their properties were nationalized, and even though their pre-war names were left or new cooperatives or societies were created, they were under the full control of the state authorities. At the end of communism in Poland, the freedom to create associations was restored, thanks to the Act of 7 April 1989, the Law on Associations (Journal of Laws of 1989, No. 20, item 104, with subsequent amendments). However, the effects of political and socioeconomic transformation directed the non-governmental organizations to mitigate the social consequences of radical market reforms carried out by Deputy Prime Minister Leszek Balcerowicz (Grygieńć, 2015).

In 1990, as a result of the first local government elections after the Second World War, an important partner of social economy entities - municipal selfgovernment - was constituted. As a result of the next self-government reform in 1999, poviat self-governments were reactivated and local governments of 16 newly created regions (voivodeships) were created in place of 49 previously functioning ones. The decentralization of public administration obtained as a result of the reform proved to be a favourable determinant for the activity of the social economy sector. In 2002, Poland participated in the First European Social Economy Conference for the EU-candidate countries, organized in Prague. Subsequently, in 2004, Poland was the host of the Second European Social Conference. The potential of the social economy was appreciated at the national level, and the social economy sector was supported by two important legal acts:

- Act of 24 April 2003 on public benefit and voluntary work (Journal of Laws of 2003, No. 96, item 873, as amended), which defines the principles of 
public benefit activities carried out by non-governmental organizations in the sphere of public tasks and the cooperation of public administration bodies with non-governmental organizations, identifies public benefit entities, defines their financing and supervision methods, provides advice for public benefit activities (with the minister for social security and local selfgovernment units), and supports the function of volunteers.

- Act of 27 April 2006 on social cooperatives (Journal of Laws of 2006, No. 94, item 651, as amended), which defines the principles of establishing, operating, merging, and liquidating social cooperatives that work for the social and professional reintegration of their members.

Poland's accession to the European Union strengthened the social economy sector, which was more developed compared to 1990. However, the most urgent issue was deficiency of due consideration of the sphere of activity of social economy entities in the strategic documents of the central and regional levels and the shortage of diversified and adequate financial resources.

From the beginning of the twenty-first century, the social economy has become one of the most important areas of EU policies, and this has been expressed, among other places, within the Community Initiative EQUAL 2000-2008 and, more broadly, within the European Social Fund. As a result of the implementation of EQUAL 2004-2008 in Poland, both methodical assumptions for the development of the social economy and specific solutions supported by the state regulatory actions were developed. Thereafter, the National Development Strategy 2007-2015 ${ }^{1}$ and the National Programme for Social Protection and Social Inclusion 2006-2008 were the driving force of the social economy, while the Citizens' Initiatives Fund and the Human Capital Operational Programme were key supports in terms of financing. Finally, in 2014, after public consultation, a strategy called the National Programme for Social Economy Development (KPRES) ${ }^{2}$ was adopted as part of the preparations for the 2014-2020 programming period (Resolution No. 164 of the Council of Ministers of 12 August 2014. MP 2014, item 811). KPRES is an operational and implementation document established in order to implement the medium-term development strategy of the country, including the National Development Strategy 2020, the Social Capital Development Strategy, the Human Capital Development Strategy, the National Strategy of Regional Development, and other development strategies (including regional ones) and according to which the social economy in 2020 will constitute an important element of public policies, contributing to employment growth, social cohesion, and the development of social capital. On the basis of KPRES, regional strategies for the development of the social economy were developed in each region. The resulting priorities have found their financial expression in the Regional Operational Programmes for the years 2014-2020. The social economy was included in the Strategy for Responsible Development adopted in February 2017. 


\section{Structure and development of social economy entities in Poland}

The concept of social economy (also called solidarity economy) is an ambiguous category. In the course of the study, the Polish definition of social economy was created, defining it as a sphere of civic activity that, through economic activity and public benefit activities, serves the professional and social integration of people at risk of social marginalization, creates jobs, and provides social services of general interest and local development (National Programme for Social Economy Development). According to the above definition, entities operating in the sphere of the social economy can be divided into the following four main groups:

1 Social enterprises that make up the foundation of the social economy.

2 Reintegration entities aimed at social and professional reintegration of people at risk of social exclusion, i.e. vocational activity centres, occupational therapy workshops, social integration centres, and clubs for social integration.

3 Entities operating in the sphere of public benefit and that conduct economic activity and employ personnel even though their activity is not based on economic risk. These are non-governmental organizations conducting paid and unpaid public benefit activities, and these entities might become social enterprises if they undertake economic activities to a certain extent as well as undertake statutory obligations regarding the distribution of profits.

4 Entities of the economic sphere but which were created in connection with the implementation of social goals or for which the social purpose of common interest is the reason for the commercial activity. These are entities that do not have all the characteristics of a social enterprise, and they can be divided into four subgroups:

i non-governmental organizations conducting economic activity, from which profits support the implementation of statutory objectives

ii entities on professional activity

iii cooperatives whose purpose is employment

iv other cooperatives of a consumer and reciprocal nature.

Currently in Poland, according to K. Wygnański (Wygnański, 2009), three categories of social economy entities operate. The first includes social enterprises, the so-called old social economy, that is, cooperatives that are involved in providing goods that go beyond satisfying the needs and interests of their members. Their activities are regulated by the Act of 16 September 1982 on Cooperative Law (Journal of Laws of 1982, No. 30, item 210, as amended). There were 17,700 cooperatives in Poland registered in the National Official Register of National Economy Entities (REGON) in 2017. The second group of social economy entities in Poland consists of non-governmental organizations, mainly 


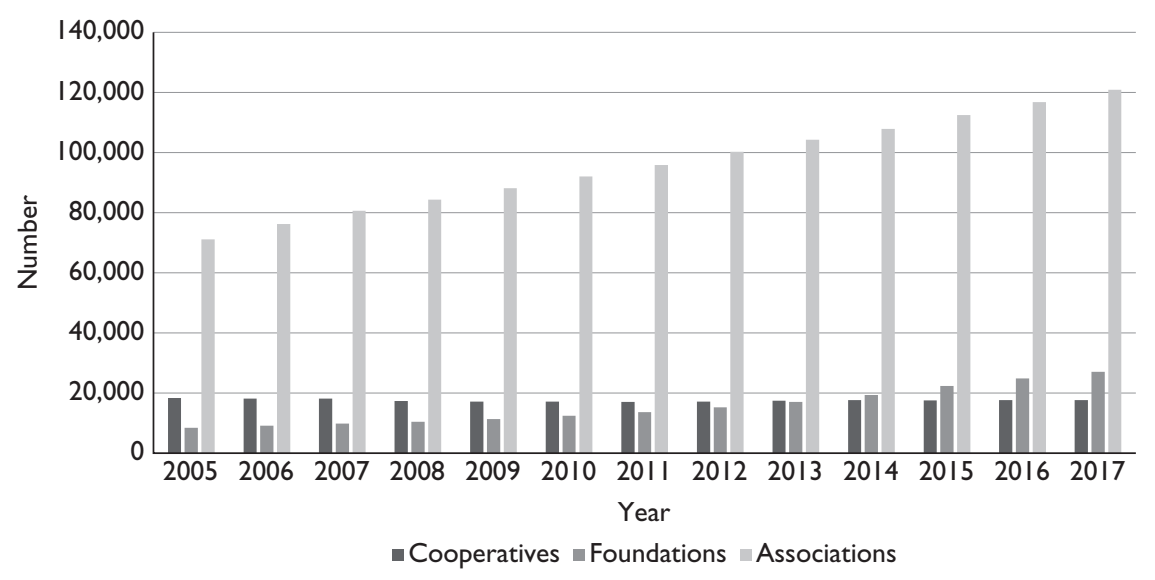

Figure 9.I Cooperatives, foundations, and associations in Poland registered in REGON.

Source: authors' interpretation of the Local Data Bank.

comprising associations (about 121,000) and foundations (about 27,000) (Figure 9.1).

In Poland the most common forms of not-for-profit organizations and nongovernmental organizations are associations and foundations. According to Polish law, an association is a self-governing, lasting (membership-based) organization formed of free will and with a non-profit motive. A foundation is defined as a non-membership organization established by a founder that pursues economically and socially beneficial objectives subject to the essential interest (such as healthcare, education, science, culture, environmental protection) of the Republic of Poland. A foundation might engage in business activity within the scope of its aims. Both associations and foundations might have the character of a public benefit organization, and some of the associations and foundations use economic instruments to achieve social goals. Wygnański (2009) estimates their number at approximately 20 per cent, stressing that in this group of social economy entities there is a great potential for the development of social enterprises.

The last group consists of the so-called new social economy entities, i.e. organizations that are more closely associated with the private sector and that focus their activities on the integration of people threatened by social exclusion in the labour market. These include social cooperatives, professional activity centres, occupational therapy workshops, social integration centres, and social integration clubs. Social cooperatives are treated as a kind of work cooperative that tries to enable its members, i.e. people who are excluded socially - the unemployed, disabled, addicted, etc. - to return to regulated social life and the labour market. They are, therefore, social enterprises with a reintegration character, functioning among 
other things in gastronomy, construction, and tourism. Participation of members and employees from the social exclusion group must be at least 50 per cent.

The other entities mentioned above in this group are also reintegration units because they serve the social and professional reintegration of people threatened with social exclusion, but they are not social enterprises. Instead, they can prepare people who are excluded to run or work in a social enterprise. The activities of these entities might also be conducted as a service for the local community by social enterprises.

Occupational activity establishments operate on the basis of the Act of 27 August 1997 on vocational and social rehabilitation and employment of disabled persons (Journal of Laws of 2004, No. 123, item 776, as amended). Their goal is professional activation of people with a moderate to significant degree of disability, and they can be created by the poviat and the commune (in which case they do not have the character of the social economy sector) or by foundations, associations, or other social organizations whose statutory purpose is the occupational and social rehabilitation of the disabled. They can receive co-financing from the State Fund for Rehabilitation of Disabled Persons and the voivodeship's self-government. Occupational therapy workshops operate on the same legal basis as professional activation centres and serve to actively support vocational and social rehabilitation of disabled people and to restore the skills needed to take up work and to live independently. Social integration centres operate on the basis of the Act of 13 June 2003 on social employment (Journal of Laws of 2003, No. 122, item 1143), and they can take the form of local government or non-governmental organizations. They provide services in the form of programmes for homeless people following an individual programme for getting out of homelessness, people addicted to alcohol, drugs, and other intoxicants, the mentally ill, the long-term unemployed, people dismissed from prisons with integration difficulties, refugees implementing an individual integration programme, and disabled people. Clubs of social integration operate on the same legal basis as centres of social integration and can be created by a municipality or a non-governmental organization. They organize full-time and part-time employment, preparation for employment, or the establishment of social cooperatives, socially useful works, public works, legal counselling, self-help activities in the field of employment, housing, and social affairs, and employee internships.

A new phenomenon under the so-called new social economy is the emergence of informal initiatives such as urban movements, tenants, and neighbourhoods, as well as the movement of cooperatives of consumers. The development of the new social economy took place first of all after the accession of Poland to the European Union, which was conditioned by changes made in both legislation and development policy, as well as the increase in the availability of financial resources to support this sector. In 2017, a total of 1456 entities of this type were registered. In the years 2005-2017 there was dynamic growth in the number of social cooperatives. Particularly dynamic growth was observed in 2012-2014, 


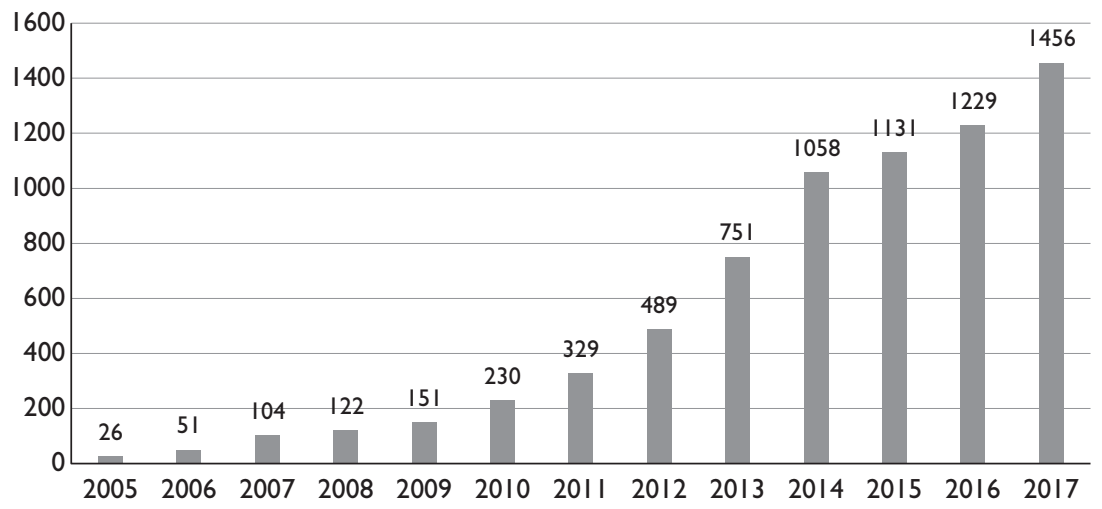

Figure 9.2 Social cooperatives in Poland in 2005-2017.

Source: own elaboration on the basis on National Catalog of Social Cooperatives. www. spoldzielniesocjalne.org/.

i.e. in the preparatory period for the new EU financial perspective for 2014-2020 (Figure 9.2), during which there was increased interest in the social economy, primarily in relation to work on the development of the National Program for Social Economy Development.

\section{Methods framework}

The transition from a centralized to a market economy led to many socioeconomic problems and challenges. After the period of socioeconomic transformation and Polish accession to the European Union, new forms of social economy organizations appeared. They were treated as a tool to solve the unfavourable situation in local and regional labour markets and then as a response to the emerging possibilities of obtaining funds from EU sources. The 'needopportunity-output' research model (Figure 9.3) was created to help analyse the correlation between the development of the social economy entities, the availability of EU funds, and the social problems of disability, poverty, unemployment, and other factors leading to social exclusion in addition to the level of social capital. We have assumed that the dynamic development of the social economy sector in Poland was caused to a large extent by needs, i.e. socioeconomic problems, as well as opportunities, including primarily financial determinants, but also legislative, political, and institutional determinants.

The analysis of factors influencing the development of the social economy sector in Poland in 2007-2013 was carried out using multiple regression. Four models were developed for this purpose. Two of them were aimed at explaining the development of social economy entities, while the other two looked at the value of the implemented projects in the area of the social economy as an 


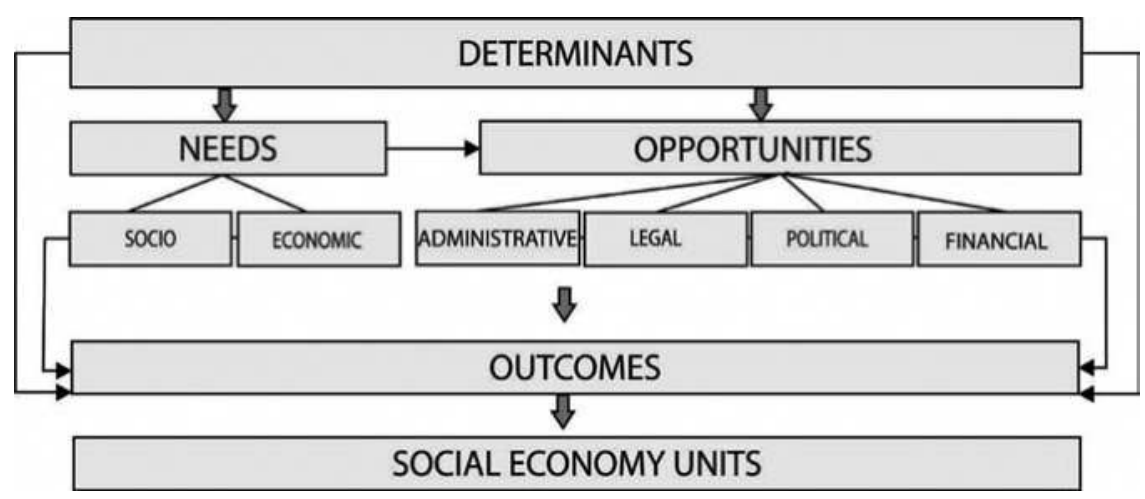

Figure 9.3 The need-opportunity-output research model.

Source: generated by the authors.

expression of their activity. In the first case, the dependent variable was the number of social cooperatives per 10,000 population, being the most popular category of the so-called new social economy entities in Poland. Due to the availability of data on the number of these units at the local level, the given variable was considered to be the best measure of the development of the modern social economy sector in Poland. In model B1 and B2 we used the value of the EU projects (in PLN) per 1000 population as the second dependent variable. This indicator can be treated as an expression of the activity of social economy entities, and thus it serves to define the involvement of social economy entities in overcoming social exclusion. Both variables indicate 'outcomes' of the development of the social economy sector in Poland after accession to the EU.

The study included a number of explanatory variables. Three of them (registered unemployment rate ${ }^{3}$, share of people benefiting from social assistance in 2015, and share of disabled people in $2011^{4}$ ) determined the intensity of social problems leading to social exclusion, i.e. unemployment, poverty, and disability. All of these could be associated with 'needs' (see Figure 9.3). The next three variables determined the level of economic and social activity of local communities. The ratio of natural persons conducting economic activity per 100 people of the population of working age reflected individual entrepreneurship. The number of cooperatives per 10,000 population was related to the entrepreneurship of a collective nature, combining economic criteria with social responsibility (i.e. traditional cooperative movements) (Kubiak, 2018). The last of the above-mentioned indicators - the number of foundations, associations, and social organizations per 1000 population - referred to so-called third-sector development and reflected the social and organizational capital of local communities. These were used as control variables that allowed for the verification 
of the extent to which the level of individual and collective entrepreneurship and the strength of the non-governmental organization sector (i.e. social 'activity') affected the development of the modern social economy sector in Poland. The analysis omits the study of the impact of the administrative, legal, financial, and political 'opportunities', due to the difficulty with quantifying these factors as well as to the fact that only after Poland's accession to the EU were appropriate conditions for the development of the entities of the social economy sector in the country created.

The A2 model differs from the A1 model by taking into account the variable value of EU projects (in PLN) per 1000 population as a variable explaining the development of the social economy sector, while the B2 model differs from B1 by taking into account the variable social cooperatives per 10,000 of population as a predictor of activity of entities in the field of social economy (value of EU projects (in PLN) per 1000 population). This means that in models A2 and B2, the explained variable from the second model was used as the explanatory variable. This was due to the fact that in Poland under the Human Capital Operational Programme, projects were financed that aimed at the development of the sector (i.e. the creation of new social economy entities), as well as projects aimed at preventing social exclusion, whose main beneficiaries were so-called new social economy entities. ${ }^{5}$

In the case of the first two models (models A1 and A2), the calculations were carried out for all poviats in Poland, ${ }^{6} \mathrm{n}=379$ ), while the B1 and B2 models accounted for 355 units. $^{7}$ The data used for the calculations were obtained from the Local Data Bank of Statistics Poland (2018), the National Catalog of Social Cooperatives (2018), and the National Information System SIMIK 07-13 (2018). All calculations were performed with the Statistica 10.0 package.

On the basis of the correlation calculations presented in Table 9.1, it can be concluded that the development of the social economy sector (measured as the number of social cooperatives per 10,000 population) is related to the intensity of social problems (the unemployment rate, the share of people benefiting from social assistance, and the share of disabled people) as well as the level of social and organizational capital of a given community, as manifested in the development of cooperatives and the third sector. On the other hand, the activity of the entities related to the development of the sector (measured with the value of $E U$ projects (in PLN) per 1000 population) shows a positive correlation with the registered unemployment rate, the number of cooperatives per 1000 population, and the number of social cooperatives per 10,000 population and a negative correlation with entrepreneurship.

The regression coefficients of the A1 model presented in Table 9.2 indicate the great importance of traditional cooperatives and the developed third sector as determinants of the development of the modern social economy sector (the number of entities). However, after including the value of EU projects (in PLN) per 1000 population (A2 model) in the variable regression equation, the strength of the relationship between traditional cooperative activity and the development of social cooperatives decreased, while the importance of the third sector turned 
Table 9.I Correlation between the control variables and the number of (new) social economy entities per 10,000 population and the value of the EU projects in the field of social economy per 1000 population (Pearson correlation coefficients, $r$ )

\begin{tabular}{|c|c|c|}
\hline & $\begin{array}{l}\text { Social economy entities } \\
\text { (social cooperatives) per } \\
\text { 10,000 population }\end{array}$ & $\begin{array}{l}\text { Value of EU projects } \\
\text { (in PLN) per } 1000 \\
\text { population }\end{array}$ \\
\hline Registered unemployment rate & $0.138 *$ & $0.453 *$ \\
\hline $\begin{array}{l}\text { Share of people benefiting from } \\
\text { social assistance in } 2015\end{array}$ & $0.220 *$ & $0.370 *$ \\
\hline $\begin{array}{l}\text { Share of disabled people in } \\
2011 \text { (Population census 201I) }\end{array}$ & $0.31 \mathrm{I} *$ & 0.078 \\
\hline $\begin{array}{l}\text { Ratio of natural persons } \\
\text { conducting economic activity } \\
\text { per } 100 \text { people of the } \\
\text { population of working age }\end{array}$ & 0.028 & $-0.227 *$ \\
\hline $\begin{array}{l}\text { Number of cooperatives per } \\
10,000 \text { population }\end{array}$ & $0.253^{*}$ & $0.309 *$ \\
\hline $\begin{array}{l}\text { Number of foundations, } \\
\text { associations, and social } \\
\text { organizations per I,000 } \\
\text { population }\end{array}$ & $0.232 *$ & 0.076 \\
\hline $\begin{array}{l}\text { Value of the EU projects (in } \\
\text { PLN) per I,000 population }\end{array}$ & $0.253 *$ & . \\
\hline $\begin{array}{l}\text { Social economy entities (social } \\
\text { cooperatives) per } 10,000 \\
\text { population }\end{array}$ & . & $0.263 *$ \\
\hline
\end{tabular}

Note

* Statistical significance at the level 0.01 .

out to be statistically insignificant. These results demonstrate the significant impact of cohesion policy on the development of the analysed sector. It turns out that the absorption of the European funds allocated for the development of the social economy sector has a greater impact on the formation of the so-called new social economy entities than it does on the level of social and organizational capital of local communities. In both cases, a relationship was also shown between the share of people with disabilities and the development of the sector. This can be explained by the activation and social inclusion of this category of people through employment in social cooperatives. This result moreover reflects a number of strategic goals and project assumptions regarding the development of the social economy sector in Poland.

The B1 and B2 models were aimed at exploring factors determining the level of absorption of the EU funds for social inclusion - which is considered an 
Table 9.2 Development of the social economy sector (social cooperatives per 10,000 population) and explanatory variables (standardized regression coefficients - beta)

\begin{tabular}{|c|c|c|}
\hline Explanatory variables & Model Al & Model A2 \\
\hline Registered unemployment rate & 0.09 & 0.04 \\
\hline $\begin{array}{l}\text { Share of people benefiting from social assistance in } \\
2015\end{array}$ & 0.04 & 0.04 \\
\hline $\begin{array}{l}\text { Share of disabled people in 201 I (Population } \\
\text { census 201I) }\end{array}$ & $0.24 * *$ & $0.24 * *$ \\
\hline $\begin{array}{l}\text { Ratio of natural persons conducting economic } \\
\text { activity per } 100 \text { people of the population of } \\
\text { working age }\end{array}$ & 0.00 & 0.02 \\
\hline Number of cooperatives per 10,000 population & $0.14 * *$ & $0.12 *$ \\
\hline $\begin{array}{l}\text { Number of foundations, associations, and social } \\
\text { organizations per } 1000 \text { population }\end{array}$ & $0.14^{*}$ & 0.11 \\
\hline $\begin{array}{l}\text { Value of the EU projects (in PLN) per } 1000 \\
\text { population }\end{array}$ & . & $0.15^{* *}$ \\
\hline$R^{2}$ (adjusted) & 0.15 & 0.17 \\
\hline
\end{tabular}

indication of the activity of social economy entities. Analysis of variables included in the models (Table 9.3) indicates the great significance of registered unemployment as a predictor of the above-mentioned explanatory variables. On this basis, it can be concluded that projects in the field of social inclusion have mostly been implemented in areas affected by permanent and high unemployment and have served to support the activation of unemployed people. This relationship also confirms the negative impact of the level of individual entrepreneurship on the analysed phenomenon. On the other hand, the value of the indicator social cooperatives per 10,000 population indicates the importance of the so-called new social economy entities as important, but not the only beneficiaries of European funds for social inclusion activities.

Summing up the conducted analysis, it should be noted that the overall impact of the analysed variables on the development of the social economy sector entities is not large, as evidenced by the relatively low level of prediction described by the values of the adjusted determination coefficient ( 15 per cent and 17 per cent for A1 and A2, respectively). Better results were obtained for the B1 and B2 models, which explain, respectively, 28 per cent and 30 per cent of the volatility of the variable value of EU projects (in PLN) per 1000 population. This means that there are other undiagnosed factors that also determine both dependent variables. 
Table 9.3 Value of EU projects (in PLN) per 1000 population and explanatory variables (standardized regression coefficients - beta)

\begin{tabular}{|c|c|c|}
\hline Explanatory variables & Model BI & Model B2 \\
\hline Registered unemployment rate & $0.37 *$ & $0.36^{*}$ \\
\hline $\begin{array}{l}\text { Share of people benefiting from social assistance in } \\
2015\end{array}$ & 0.01 & 0.01 \\
\hline $\begin{array}{l}\text { Share of disabled people in 201 I (Population } \\
\text { census 20II) }\end{array}$ & 0.00 & -0.04 \\
\hline $\begin{array}{l}\text { Ratio of natural persons conducting economic } \\
\text { activity per } 100 \text { people of the population of } \\
\text { working age }\end{array}$ & $-0.14 *$ & $-0.14 *$ \\
\hline Number of cooperatives per 10,000 population & $0.26 *$ & $0.24 *$ \\
\hline $\begin{array}{l}\text { Number of foundations, associations, and social } \\
\text { organizations per } 1000 \text { population }\end{array}$ & 0.06 & 0.04 \\
\hline $\begin{array}{l}\text { Social economy entities (social cooperatives) per } \\
\text { I0,000 population }\end{array}$ & . & $0.17 *$ \\
\hline $\mathrm{R}^{2}$ (adjusted) & 0.28 & 0.30 \\
\hline
\end{tabular}

Note

* Statistical significance at the level 0.01 .

On the basis of the obtained results, it can be seen that there is a relationship between the development of the social economy sector in Poland and the occurrence of real problems and social needs (unemployment, disability). Data analysis also indicates that the development of the social economy sector is conditioned by the availability of European funds, which have allowed for the increase in the number of so-called new social economy entities, as well as their activation, by guaranteeing financial support for their activities. At the same time, the more dynamic development of the sector and its greater activity in the scope of the social economy has been seen in the areas characterized by a greater intensity of various types of previously existing bottom-up and non-state forms of self-organization of the society. This means that the existence of a well-developed cooperative sector and the so-called third sector as a form of social and organizational background was the important prerequisite for the success of activities related to development of the social economy sector under the auspices of the cohesion policy in Poland.

It is difficult to say whether the patterns described here of the development of the social entities in Poland are related to the experience of several decades of the socialist system in Poland. There is no doubt that during the time of socialism in Central and Eastern Europe countries with centrally planned economies the state was the only economic actor, and social economy entities practically disappeared as a significant force in the process of economic growth. The post-socialist legacy definitely influenced to some extent the character and 
development of the social economy sector in Poland. On the other hand, SE seems to be an appropriate and effective tool that can be adjusted to the specificity of social problems that are characteristic for a post-socialist state like Poland, and thus is more suited to deal with them. The first of the above-described phenomena was influenced by the singular ability of Polish society to cooperate in order to achieve common goals shaped under the conditions of a totalitarian system. The activities of various off-the-record organizations of a political, social, cultural, educational, and even economic nature were of a bottom-up nature and were based on personal initiatives and connections, and this empowered the civic sphere as a whole (Praszkier et al., 2014). According to A. Churchill, nowadays 'being a postcommunist country, Poland is eager to develop a strong civic society and avoid the extremes of capitalism and communism, and social enterprise is seen as perhaps the key to "a different way" (Cahalane, 2011). In contrast, communism prevented many citizens from acting on their own, and this was especially the case for less developed rural areas affected by many social and economic problems. One of the most important features of the so-called post-communistic mentality is, among other things, a lack of faith in success. Therefore, social entrepreneurship is a way to decrease social apathy and to encourage people to express their own needs and to overcome existing social problems (Praszkier et al., 2014).

\section{Conclusions}

The social economy plays an important role in supporting economic development and improving economic well-being. However, the differences in legal status, types, forms, and structures of the social economy entities in different countries mean that there is no single, widely accepted definition or single universal model. The Polish social economy sector includes various forms of organizations ranging from the so-called old, i.e. more traditional, organizations to new forms of organizations that are associated with the private sector and are aimed at eliminating unfavourable phenomena such as social exclusion. The evolution of the social economy sector in Poland shows that it has the capacity to play a significant role in regional development. Social economy entities represent a nascent resource for labour market integration processes, and they are perceived as one of the most effective social inclusion initiatives. The rapid growth of social economy entities in Poland in the last few decades has been conditioned by a set of different factors, including the intensity of the social problems arising but also to a large extent due to the possibility of financing their activities with European Union funds.

The conducted research showed that the presence of social, intellectual, organizational, and physical capital were among many factors that contributed to the development of the social economy sector at the regional level. The survey also revealed the relationship between the occurrence of social economy entities and the reduction in the intensity of socioeconomic problems at the regional level. This is especially important because of the fact that social exclusion in Poland is primarily associated with barriers to the labour market and thereby 
might have long-term consequences for social integrity and cohesion. However, although in recent decades the social economy has become more appreciated, it does not provide a universal cure-all for all socioeconomic problems caused by the regional disparities. Therefore, the applied solutions and tools should be adapted to current developmental challenges and should be treated as a complementary sphere to other areas of the economy.

\section{Notes}

1 In the National Development Strategy 2007-2015, the issues of the social economy were included in two priorities, i.e. priority 3 , in which there is talk of increasing employment and raising its quality, including the announcement of strengthening the share of the social economy sector/non-governmental organizations in the employment process through activities such as implementation of employment promotion programmes and promotion of non-governmental organizations as employers, as well as combining employment in non-governmental organizations with support for groups at risk of social exclusion. In turn, priority 4 includes provisions on building an integrated social and security community, where integration and social activation will be promoted, in particular the development of social employment institutions, social cooperatives, social housing, and the vocational and social rehabilitation of disabled people, as well as the development of social and other contracts and activating instruments. Actions will be taken to create an inclusive labour market for people in a difficult situation or at risk of social exclusion.

2 The National Programme for Social Economy Development consists of six chapters. In the first chapter, definitional issues are addressed, and in the diagnostic part statistics of the social economy sector are presented, including the scale and scope of its current support system. Expectations regarding this sector are also formulated. In the second chapter, indicating the place and significance of the Programme in the structure of government priorities, the main objective and specific goals are defined together with the results and indicators assigned to them. In the third chapter, priorities, activities, and specific directions of public intervention are set. The fourth chapter contains a description of how to monitor the Programme implementation process, the fifth chapter presents the basic assumptions of the implementation system, and the sixth chapter presents a financial plan required and appropriate for the development programme.

3 Due to significant fluctuations in the indicator's value over time, the study used the geometric mean for the years 2007-2015.

4 National Population Census 2011 data.

5 Based on the available data, it was not possible to separate the two categories of projects.

6 Apart from the Wałbrzych poviat, created in 2013.

7 All poviats of the Małopolskie voivodeship have been removed from the model (due to the incompleteness of the data on the value of EU projects in the field of social economy) as well as the Bieszczady and Szydlowiec poviats (outliers).

\section{Bibliography}

Bank Danych Lokalnych. (2018). Warszawa: Główny Urząd Statystyczny, https://bdl.stat. gov.pl/BDL/start. (Local Data Bank, Statistics Poland).

Baza Podmiotów Ekonomii Społecznej, http://ekonomiaspoleczna.lubelskie.pl/bazapodmiotow-ekonomii-spolecznej. (Database of Entities of Social Economy.) 
Cahalane, C. (2011). The state of the social enterprise sector in Poland, Guardian 10 February, www.theguardian.com/social-enterprise-network/2011/feb/10/social-enterprisepoland-sector. [Accessed 31 January 2019].

Churski, P. (2011). Spójność a przestrzeń - dylematy polityki regionalnej (Cohesion and space - the dilemmas of regional policy), Rozwój Regionalny i Polityka Regionalna (Regional Development and Regional Policy) 15, pp. 98-108.

Defourny, J., Develtere, P., and Fonteneau, B. (1999). L'économie sociale au Nord et au Sud. Bruxelles: De Boeck.

European Commission (2011). Summary report: A European ecosystem for social business. Brussels: EC.

European Parliament (2008). European Parliament report on the social economy (2008/2250 (INI)).

Gąska, J., Kozłowski, W., Koloch, G., Lis, M., Regulski, A., and Skrok, Ł. (2009). Spójność wewnętrzna a konkurencyjność regionu tódzkiego. Diagnoza strategiczna. Raport $z$ badań (Internal cohesion and competitiveness of the Lodz region. Strategic diagnosis. Research report). Warszawa: Instytut Badań Strukturalnych.

Goleński, W. (2018). Uwarunkowania efektywności funkcjonowania podmiotów ekonomii społecznej (Conditions for the effectiveness of social economy entities' operations). In: D. Murzyn and J. Pach, eds., Ekonomia społeczna. Między rynkiem, państwem a obywatelem (Social economy. Between the market, state and citizen). Warszawa: Difin, pp. 156-172.

Grygieńć, J. (2015). Post-transitional social economy: the case of Poland. International Journal of Social Economics 42(9), 817-829.

Kontrakt Terytorialny dla Województwa Lubelskiego (Territorial contract for the Lublin Province). (2014). Lublin: Zarząd Województwa Lubelskiego, www.miir.gov.pl/ media/3260/KT_Lubelskie_05122014.pdf.

Krajowy Program Rozwoju Ekonomii Społecznej (National program for the development of social economy) (2014). Warszawa: Uchwała Nr 164 Rady Ministrów z dnia 12 sierpnia 2014 r. M.P 2014 poz. 811.

Krajowy Program Zabezpieczenie społeczne i integracja społeczna na lata 2008-2010 (National program social security and social integration for 2008-2010) (2008). Warszawa: Ministerstwo Pracy i Polityki Społecznej. http://analizy.mpips.gov.pl/images/ stories/publ_i_raporty/krajowy_program_2008_2010.pdf.

Kubiak, M. (2018). Systemowe uwarunkowania rozwoju spółdzielni socjalnych w województwie pomorskim (Systemic determinants of the development of social cooperatives in the Pomeranian Voivodeship). In: D. Murzyn and J. Pach, eds., Ekonomia społeczna. Między rynkiem, państwem a obywatelem (Social economy. Between the market, state and citizen). Warszawa: Difin, pp. 139-155.

Monzon, J.K. and Chaves, R. (2012). The social economy in the European Union. Brussels: European Economic and Social Committee.

Nicholls, A. (2006). Introduction. In: A. Nicholls, ed., Social entrepreneurship: new models of sustainable social change. Oxford: Oxford University Press, pp. 1-35.

Ogólnopolski katalog spółdzielni socjalnych (Polish catalog of social cooperatives). www.spoldzielniesocjalne.org/lubelskie.htm.

Praszkier, R., Zabłocka-Bursa, A., and Jozwik, E. (2014). Social enterprise, social innovation and social entrepreneurship in Poland: a national report. Warsaw: University of Warsaw. 
Regionalny program rozwoju ekonomii społecznej $w$ województwie lubelskim do roku 2020 (Regional program for the development of the social economy in the Lublin province until 2020) (2016). Lublin: Regionalny Ośrodek Polityki Społecznej w Lublinie, Uchwała nr CVIII/2216/2016 Zarządu Województwa Lubelskiego z dnia 14 czerwca 2016 r. http://ekonomiaspoleczna.lubelskie.pl/images/artykuly/Regionalny_Program Rozwoju_Ekonomii_Spolecznej_w_wojewodztwie_lubelskim_do_roku_2020-min.pdf. Strategia Polityki Spotecznej Województwa Lubelskiego na lata $201 \overline{4}-2020$ (Social policy strategy of the Lubelskie Voivodeship for the years 2014-2020) (2014). Lublin: Regionalny Ośrodek Polityki Społecznej w Lublinie. www.lubelskie.pl/file/2018/02/5f.ROPS-Strategia-Polityki-Spo\%C5\%82ecznej-Wojew\%C3\%B3dztwa-Lubelskiego-nalata-2014-\%E2\%80\%93-2020.pdf.

Strategia Rozwoju Kraju 2007-2015 (National development strategy 2007-2015) (2006). Warszawa: Ministerstwo Rozwoju Regionalnego. http://wrpo2007-2013.wielkopolskie. pl/downloads/dokumenty_krajowe/Strategia_Rozwoju_Kraju_dokument_przyjety_ przez_RM_29_listopada_2006_roku.pdf.

Strategia Rozwoju Województwa Lubelskiego na lata 2006-2020. Tom II: Cele i priorytety strategii oraz system wdrażania (The development strategy of the Lubelskie Voivodeship for the years 2006-2020. Volume II: objectives and priorities of the strategy and implementation system) (2005). Lublin: Zarząd Województwa Lubelskiego, www. npf.rpo.lubelskie.pl/front/page/get/281/.

Strategia rozwoju województwa lubelskiego na lata 2014-2020 (z perspektywa do 2030 r.) (Strategy for the development of the Lubelskie Voivodeship for the years 2014-2020 (with prospects until 2030) (2014). Lublin: Urząd Marszałkowski Województwa Lubelskiego. www.strategia.lubelskie.pl/Strategia_Rozwoju_Wojewodztwa_Lubelskiego_ na_lata_2014-2020_z_perspektywa_do_2030_roku.pdf.

Ustawa z 13 czerwca 2003 roku o zatrudnieniu socjalnym (Dz.U. 2003 nr 122 poz. 1143).

Ustawa z 16 września 1982 roku Prawo spółdzielcze (Dz.U. $1982 \mathrm{nr}$ 30, poz. 210 z późniejszymi zmianami).

Ustawa z 27 sierpnia 1997 roku o rehabilitacji zawodowej i społecznej oraz o zatrudnieniu osób niepetnosprawnych (Dz.U. nr 123 poz. 776 z późniejszymi zmianami).

Wieloletni regionalny plan działań na rzecz promocji i upowszechniania ekonomii społecznej oraz rozwoju instytucji sektora ekonomii społecznej i jej otoczenia w województwie lubelskim na lata 2013-2020 (A multi-annual regional action plan for the promotion and dissemination of the social economy and the development of institutions of the social economy sector and its environment in the Lubelskie Voivodeship for the years 2013-2020). www.flop.lublin.pl/media/Ekonomia_Spoleczna/Wieloletni_plan_ dzialan_na_rzecz_ekonomii_spolecznej.pdf.

Wilson, K.E. (2014). New Investment Approaches for Addressing Social and Economic Challenges, OECDScience, Technology and Industry Policy Papers, No. 15, OECD Publishing. http://dx.doi.org/10.1787/5jz2bz8g00jj-enOECD Science, Technology and Industry Policy Papers No. 15. New Investment Approaches for Addressing Social and Economic Challenges.

Wygnański, K. (2009). O ekonomii społecznej-podstawowe pojęcia, instytucje i kompetencje (On social economy - basic concepts, institutions and competences). Szczecin: Stowarzyszenie czas Przestrzeń Tożsamość. 


\title{
The promotion of social inclusion in the Slovak education system through 'Teach for Slovakia' programme
}

\author{
Gábor Szüdi and Jaroslava Szüdi
}

\section{The Slovak primary and secondary school system in international comparison in terms of equity and excellence}

The European Union (EU) has been concerned with combating social exclusion and achieving higher social inclusion at least since the 1989 formation of the Observatory on Policies to Combat Social Exclusion; however, the concrete policy measures aimed at decreasing the number of people at risk of poverty and social exclusion ${ }^{1}$ were mainly focused on the functioning of social protection systems until 1997 when a paradigm shift took place towards a more broadly defined social protection objective, officially formulated as a fight against social exclusion in the Amsterdam Treaty in 1999. Education as a means to achieve social inclusion has been on the official agenda of the European Union since then.

The objective of a more inclusive education in the EU serves the purposes of the overarching aim of having a 'decisive impact on the eradication of poverty' (European Commission, 2005). The European Commission argued that:

the fight against poverty and exclusion needs to rely on growth and employment as well as modern and effective social protection. Moreover, social protection intervention must be combined with a broad set of social policies including targeted education [...], all areas where welfare systems have so far tended to intervene with residual programmes.

(European Commission, 2010)

For the purposes of operationalization, commonly agreed on indicators (based on the work of Atkinson et al., 2002) have been adopted for each EU Member State corresponding to actual EU-level strategic objectives implemented through the open method of the coordination mechanism (Schoukens et al., 2015). The Commission's first joint report on social inclusion in 2002 had already identified poor qualifications and early school drop-out as risk factors increasing the danger of poverty, and it named 'tackling educational disadvantages' among the 
eight core challenges to address in order to achieve social inclusion (European Commission, 2001).

In this sense, the Europe 2020 Strategy's two EU-level target indicators on education - the decrease of the share of early school leavers to below 10 per cent by 2020 and achieving a minimum share of 40 per cent of people aged 30-34 with a higher education degree by 2020 - are mutually reinforcing and interrelated with the target set for social inclusion, i.e. moving at least 20 million people out of social exclusion by 2020 .

Lately, the European Union has aimed to better conceptualize the specific role that education plays in strengthening social inclusion, and it has adopted recommendations to help build inclusive cohesive societies through education. These recommendations - in particular, the Council Recommendation on Key Competences for Lifelong Learning and the Council Recommendation on promoting Common Values, Inclusive Education, and the European Dimension of Teaching, both adopted in 2018 - serve as a basis for new or revised objectives and indicators going beyond the output indicators related to the Europe 2020 Strategy that measure inclusion in education in line with the broader understanding of social exclusion - as Eurostat (2013) formulated it: 'The complexity of the concept of social exclusion has resulted in the elaboration of a portfolio of indicators which represent more broadly its various facets.'

The Slovak primary and secondary school system is presented in the following section by means of these indicators measuring its excellence, equity, and inclusion compared to other European school systems, taking into account the role of education in building inclusive societies as highlighted by the recent European-level developments mentioned above.

The period of compulsory schooling in Slovakia is ten years (age 6-16) and covers basic schooling at two levels: the primary level (4 years), and the secondary level - lower level of secondary education (5 years). Primary and secondary education in all forms of public schooling is free of charge, and various forms of financial support for children from disadvantaged families exist (including for care, meals, and materials). Secondary schools include, among others, grammar schools $(4,5$, or 8 years, ending with a secondary school leaving certificate, preparing students primarily for university studies), secondary vocational schools (2-5-year programmes preparing students for professional occupations through theoretical education and practical training), and conservatories (6- or 8-year programmes in artistic-pedagogical fields). Apprentice schools have been set up for those 15-year-old children who have not successfully completed basic school in order to prepare them for less demanding professional occupations. There are also special basic schools for children with special educational needs, and for educating children from socially and psychologically disadvantaged families. They differ only in terms of curriculum and educational strategy. The system also provides for a preschool class (year 0) for 6-year-olds coming from a disadvantaged background who do not meet the requirements for compulsory education (Kosova and Porubsky, 2015). 
The current system is the result of several reforms undertaken since the country's declaration of independence in 1993 even though a spontaneous process of democratization had already started at the beginning of the 1990s with the set-up of school self-administration bodies and the establishment of private and church schools (return to pluralism). The first official government strategy ('Millennium') was only adopted in 2001 and focused on 12 areas to be developed in 10-15 years to reach higher standards in education (Zelina, 2005).

These reform steps started to dismantle the centralized education system based on communist ideology in the 1990s (strict regulation of curriculum, material, and technical and personal provision and legal supervision of a uniform system with state-financed and maintained schools), but official decentralization only started in line with the Millennium strategy. Local communities and parent authorities became the maintainers of schools - formerly the sole responsibility of the state - and schools started to be funded from various sources based on a newly established normative system of funding (Siskovic and Toman, 2015); see Table 10.1.

With regard to social inclusion and to align its legislation with EU law, Slovakia adopted Act No. 365/2004 on Equal Treatment in Certain Areas and Protection against Discrimination in the year of its EU accession (2004). In line with this anti-discrimination act, an important educational reform was implemented in 2005 regulating the quality of opportunity in education with the aim of ending segregation, e.g. opening up primary schools to children with special educational needs or disadvantaged backgrounds, which was not possible based on the previous law adopted in 1984.

The school integration of Roma people, as the most disadvantaged group of the population, has been separately dealt with in various subsequent strategies, the latest of which is called the Slovak Republic's 2014-2020 Strategy for Roma Integration, which has a special emphasis on the elimination of segregation at schools, the prevention of early school leaving (by introducing a year 0 offering compensatory lessons to Roma children), and ensuring a successful transition to the labour market. The impact of such a reform step was limited without related curricular reforms (Kosova and Porubsky, 2015).

This oversight was corrected by the 2008 Act on Upbringing and Education (replacing the old socialist law adopted in 1984), which among other things introduced a new two-level participative curriculum model where minimum content and primary skills and competencies were formulated at the national level by the relevant ministry (State Educational Programmes), while each school was given the responsibility and autonomy to develop School Educational Programmes within the national framework. Educational standards guarantee that the minimum state-provided content is taught at the required level of quality. The framework study plan defines the structure of instruction of the minimum compulsory educational content within the obligatory study time (Siskovic and Toman, 2015). The option for more flexible curriculum building was strengthened by the new Pedagogical and Specialized Employees Act in 2009 granting 
Table 10.I School founders and types of schools in Slovakia

\begin{tabular}{|c|c|c|c|c|c|}
\hline & State & & & Church & Private \\
\hline Founder & $\begin{array}{l}\text { State administration } \\
\text { Regional state } \\
\text { authorities }\end{array}$ & $\begin{array}{l}\text { Self-governing } \\
\text { region }\end{array}$ & Municipality & $\begin{array}{l}\text { Registered } \\
\text { churches and } \\
\text { religious } \\
\text { communities }\end{array}$ & $\begin{array}{l}\text { Other natural } \\
\text { persons or legal } \\
\text { entities }\end{array}$ \\
\hline $\begin{array}{l}\text { Prevailing types of } \\
\text { schools }\end{array}$ & $\begin{array}{l}\text { Special } \\
\text { kindergartens, } \\
\text { special basic } \\
\text { schools, special } \\
\text { secondary schools }\end{array}$ & Secondary schools & $\begin{array}{l}\text { Basic schools, } \\
\text { kindergartens }\end{array}$ & $\begin{array}{l}\text { Basic schools, } \\
\text { secondary schools, } \\
\text { special basic } \\
\text { schools, special } \\
\text { secondary schools }\end{array}$ & $\begin{array}{l}\text { Basic schools, } \\
\text { secondary schools, } \\
\text { special basic } \\
\text { schools, special } \\
\text { secondary schools }\end{array}$ \\
\hline
\end{tabular}

Source: Siskovic and Toman, 2015. 
teachers greater freedom to choose pedagogical methods and training approaches (OECD, 2015).

If the country's educational performance is assessed in a narrower sense, the step-by-step reforms in education produced some results in terms of the official headline Europe 2020 target indicators. Slovakia's performance is better than the EU average in two aspects. The share of early school leavers among 18-24-yearold people is lower (9.3 per cent compared to an EU average of 10.6 per cent) and the share of people with at least upper secondary educational attainment in the age cohort of 25-64 years is greater (91.4 per cent compared to an EU average of 77.5 per cent), but Slovakia is still below the EU average in terms of people aged 30-34 with a tertiary educational attainment (34.3 per cent compared to an EU average of 39.9 per cent). Such results should not be surprising because the country has focused on improving these aspects at least since the 'Konstantín' strategy in 1994 that aimed at increasing the number of students leaving secondary education and admitted to tertiary study (Kosova and Porubsky, 2015).

Table 10.2 provides an overview on the Slovak performance concerning the Europe 2020 targets in education compared to the other Visegrad (V4) countries in Central-Eastern Europe. The data show that the post-socialist heritage is still visible in all countries in terms of above-average upper secondary educational attainment and below-average rate of early school leaving. This is partly due to the official stance in communist ideology to provide a level of education deemed sufficient in the labour market to the broadest population segment possible. Because participation in tertiary education was not such a prominent goal in the state socialist era, all V4 countries - with the potential exception of Poland struggle to reach the Europe 2020 target of 40 per cent (and even their officially set lower goals) without the initial 'hereditary' advantage.

Some Slovak trends, however, signal a country-level problem. In recent years, the share of early leavers from school has increased and is now above the official Slovak target (but still below the EU-level target and average), which hints at dysfunctions in the Slovak education system. The problems are more prominently displayed when a broader portfolio of indicators is used to assess the Slovak education system from an inclusion and equity perspective. As the recent OECD study on educational equity points out, more people in upper secondary and tertiary education is a prerequisite for, but does not automatically result in, a higher level of educational excellence and equity (OECD, 2018b).

This holds true for the Slovak education system because - despite the ongoing Slovak reforms changing the inherited socialist structure of education in several aspects - the country underperforms in excellence and equity measures in international comparison. If we take the OECD's PISA (Programme for International Student Assessment) survey as a benchmark, then Table 10.3 shows that the 15-year-old students in Slovakia are the worst performers in science, mathematics, and reading $(O E C D, 2016)$. In all three subjects measured, Slovakia was below the average of OECD countries and - with the exception of mathematics in 2012 - was 
Table 10.2 Educational indicators of Slovakia in international comparison

\begin{tabular}{|c|c|c|c|c|c|c|c|c|c|}
\hline & \multicolumn{3}{|c|}{$\begin{array}{l}\text { Early leavers from education, } \% \text { of age } \\
\text { group } 18-24\end{array}$} & \multicolumn{3}{|c|}{$\begin{array}{l}\text { Tertiary educational attainment, \% of } \\
\text { population aged 30-34 }\end{array}$} & \multicolumn{3}{|c|}{$\begin{array}{l}\text { People with at least upper secondary } \\
\text { educational attainment, \% of age group } \\
25-64\end{array}$} \\
\hline & 2017 & $\begin{array}{l}\text { Change } \\
\text { since } 2005\end{array}$ & $\begin{array}{l}\text { Europe } \\
2020 \text { target }\end{array}$ & 2017 & $\begin{array}{l}\text { Change } \\
\text { since } 2005\end{array}$ & $\begin{array}{l}\text { Europe } \\
2020 \text { target }\end{array}$ & 2017 & $\begin{array}{l}\text { Change } \\
\text { since } 2005\end{array}$ & $\begin{array}{l}\text { Europe } \\
2020 \text { target }\end{array}$ \\
\hline EU-28 & 10.6 & -5.1 & 10.0 & 39.9 & +11.8 & 40.0 & 77.5 & +8.1 & - \\
\hline SK & 9.3 & +3.0 & 6.0 & 34.3 & +20.0 & 40.0 & 91.4 & +3.5 & - \\
\hline$C Z$ & 6.7 & +0.5 & 5.5 & 34.2 & +21.2 & 32.0 & 93.8 & +3.9 & - \\
\hline $\mathrm{HU}$ & 12.5 & 0.0 & 10.0 & 32.1 & +14.2 & 34.0 & 84.0 & +7.6 & - \\
\hline PL & 5.0 & -0.4 & 4.5 & 45.7 & +23.0 & 45.0 & 92.1 & +7.3 & - \\
\hline
\end{tabular}

Source: Eurostat, 2018. 
Table 10.3 PISA results of I5-year-old Slovak students at the last two measurement rounds

\begin{tabular}{|c|c|c|c|c|c|c|}
\hline \multirow{3}{*}{ Country } & \multicolumn{6}{|c|}{ Mean score in } \\
\hline & \multicolumn{2}{|c|}{ Science } & \multicolumn{2}{|c|}{ Mathematics } & \multicolumn{2}{|c|}{ Reading } \\
\hline & 2006 & 2015 & 2012 & 2015 & 2009 & 2015 \\
\hline$O E C D$ & 498 & 493 & 494 & 490 & 493 & 493 \\
\hline SK & 488 & 461 & 482 & 475 & 477 & 453 \\
\hline$C Z$ & 513 & 493 & 499 & 492 & 478 & 487 \\
\hline $\mathrm{HU}$ & 504 & 477 & 477 & 477 & 494 & 470 \\
\hline PL & 498 & 501 & 518 & 504 & 500 & 506 \\
\hline
\end{tabular}

Source: OECD, 2016.

the last within its own closer region among the V4 countries. Despite the adoption of a new Education Act and related reforms, the trends are also negative in all three aspects - there is no other V4 country with a similar unequivocally worsening trend (Hungary nevertheless shows a very similar trend in the longer term).

For the purposes of our research, the PISA results on social inclusion and equity in education are even more relevant than the results on excellence. Equity in education means that all children - irrespective of their socioeconomic status - are provided with equal opportunities to acquire the skills required on the labour market. Equity does not mean that all students obtain equal educational outcomes, but that the differences in study outcomes (measured by, for instance, PISA tests on reading, science, and mathematics) are not significantly related to students' traits over which they have no control, such as family background and economic and social circumstances (OECD, 2018b). In this sense, socioeconomic status is a concept summarizing many different aspects of a student and is measured by an index based on such indicators as parental education and occupation, the number and type of home possessions, and educational resources at home (OECD, 2013).

Table 10.4 shows that Slovak students' socioeconomic background is more strongly related to their science, mathematics, and reading performance than the OECD average. In addition, in comparison to the OECD average, more Slovak children from disadvantaged backgrounds are taught at disadvantaged schools (schools where the share of students with tertiary-educated parents are in the bottom $25 \%$ in a country), exposing them to a 'double disadvantage' - fewer children feel socially integrated at their schools (partially due to this double disadvantage) and fewer disadvantaged students are 'core-skills resilient', meaning that they receive at least level-3 scores in all subjects (science: 484 points; reading: 480 points; and mathematics: 482 points).

The post-socialist heritage in education contributes to the fact that all V4 countries have similar results and struggle with ensuring a level of equity 
Table 10.4 Educational inequality measures in Slovakia in international comparison

\begin{tabular}{|c|c|c|c|c|c|c|c|c|c|}
\hline \multirow[t]{3}{*}{ Factor } & \multicolumn{6}{|c|}{ Variation explained by student's socio-economic status in } & \multicolumn{3}{|c|}{ Disadvantaged students who are } \\
\hline & \multicolumn{2}{|c|}{ Science } & \multicolumn{2}{|c|}{ Mathematics } & \multicolumn{2}{|c|}{ Reading } & \multirow{2}{*}{$\begin{array}{l}\text { in } \\
\text { disadvantaged } \\
\text { schools } \\
2015\end{array}$} & \multirow{2}{*}{$\begin{array}{l}\text { socially } \\
\text { integrated } \\
\text { at school }\end{array}$} & \multirow{2}{*}{$\begin{array}{l}\text { resilient in } \\
\text { core skills }\end{array}$} \\
\hline & 2015 & $\begin{array}{l}\text { Change } \\
\text { since } 2006\end{array}$ & 2015 & $\begin{array}{l}\text { Change } \\
\text { since } 2003\end{array}$ & 2015 & $\begin{array}{l}\text { Change } \\
\text { since } 2000\end{array}$ & & & \\
\hline OECD & 12.9 & -1.4 & 13.1 & -3.7 & 11.9 & -2.4 & 48.0 & 80.5 & 25.2 \\
\hline SK & 16.0 & -3.6 & 15.8 & -7.7 & 16.9 & 1.8* & 50.3 & 72.7 & 15.7 \\
\hline$C Z$ & 18.8 & 2.7 & 20.6 & 4.4 & 17.9 & -3.2 & 50.7 & 76.4 & 20.4 \\
\hline HU & 21.4 & 0.3 & 21.3 & -4.5 & 21.7 & -3.6 & 55.3 & 79.5 & 14.0 \\
\hline PL & 13.4 & -1.4 & 12.2 & -4.7 & 12.5 & -1.6 & 46.3 & 78.9 & 30.3 \\
\hline
\end{tabular}

Source: OECD, 2018b.

Notes

* Data for change only available from 2009.

All values given in percentage. 
deemed average in the OECD area. Poland seems to be the outlier in the V4 group, and it is the only country with an overall closer-to-average value (and better-than-average values in desegregation, core skills resilience, and equity in mathematics), as well as a generally improving trend in all fields moving towards a more inclusive and equitable education system. In contrast, Slovakia lags even behind the V4 group, and only Hungary has a tendency for higher variation in school performance explained by socioeconomic status in all subjects. However, Slovakia is the worst performer in terms of social integration, and the trends are unambiguous in the long run. From this process perspective, following Kosova and Porubsky (2015), we consider that the main problem contributing to high inequity and low rates of excellence in the Slovak education system is the negligence of the broader socioeconomic environment of education during the implementation of subsequent government strategies. The educational reforms were not comprehensive enough, but rather followed a pattern resembling a series of ad hoc measures lacking a more systematic perspective, with the general approach of subordinating the principles of social security and equality to the objective of enhancing economic competitiveness. Kascak and Pupala (2014) argue that this marketization process of education is the result of a (hidden) neoliberal agenda of subsequent governments; however, it is likely that the current state has come about rather for a variety of interrelated politico-economic reasons without a guiding principle, such as the weak political consensus on a long-term educational strategy, inappropriate or non-existing background studies, delayed or inconsistent implementation of legislative measures and regulations, and shortage of financial and human resources.

Through various measures, such as public expenditure cuts or the decentralization of school management and competences, the role of the state in education governance and management has been gradually weakened, leading to the current 'hybrid' education system including both post-socialist (centralized and collectivistic) and market economy (individualized, decentralized, and deregulated) features. The market economy aspects include free school choice, school self-administration, coexistence of various types of schools (public, private, and church), and the decentralization of governance and funding, while the postsocialist heritage comprises the detailed national education programmes that limit free curriculum-building, the central market of books for study purposes, the centrally issued regulations and methodological guidance for schools and teachers, and the fixed (and low) teachers' salaries and the related low prestige of the teaching profession (Bútora and Kríž, 2013).

Thus, the root of prevalent performance gaps in terms of educational equity and excellence compared to other OECD countries is the inclusion of certain market mechanisms in an education system based on a socialist structure operating within a broader socioeconomic environment still confronted with dilemmas stemming from the rapid socioeconomic transformation process. For instance, the high level of school segregation (disadvantaged students within disadvantaged schools) can be seen as a result of market elements introduced in recent 
decades. Free school choice means that parents have the right to send their children to any basic school they prefer, and school leaders have the autonomy to decide on enrolment (with a compulsory preference to children in their school districts) but have an interest to admit as many students as possible (due to another key market principle in the system, i.e. 'money follows students' through normative funding). While in principle this system should ensure equal opportunities, in reality it results in a horizontal segregation where disadvantaged students are less likely to be admitted to mainstream schools.

The situation is worst for Roma children, who are overrepresented in special schools or classes and are thereby subject to segregated education even in mainstream schools (mainly due to social disadvantages and not learning disabilities, which seems to be another post-socialist tradition rooted in the Czechoslovak past - see Kovács, 2015). A study on Roma conducted by the European Union Agency for Fundamental Rights (FRA, 2014) shows that 58 per cent of Roma students in areas where Roma live in higher density are enrolled in segregated classes, and 20 per cent of Roma students attend special classes or schools. The ethnic trait first manifests in residential segregation through loss of jobs and discrimination, which turns into educational segregation reinforced by poorly functioning complementary supporting services causing information asymmetry (Németh et al., 2014).

The horizontal segregation is coupled with vertical segregation because children can already be selected to follow different school paths at the age of 11 (compared to the OECD average of 14 years) based on their academic records (the best pupils go to an 8-year grammar school). Prior to the end of compulsory schooling, the next selection takes place where students go to various forms of secondary schooling for a minimum of 1 year. Subsequent division of children into separate tracks is in itself not inequity-enhancing because its effectiveness depends on country and school factors (Beblavý and Veselková, 2014), but PISA data show that the performance of Slovak students is closely related to their socioeconomic status and therefore the unintended result of separating students by achievement might lead to student segregation by socioeconomic status. Because the partly state-funded private schools are not obliged to admit every child to the first grade, a further differentiation within the system appears. Slovak non-state students tend to achieve better results than those in state schools, represented also by a 42-point better performance in mathematics on the 2012 PISA survey - and this difference is above the OECD average (Siskovic and Toman, 2015). The segregation is facilitated by the low rate of Roma participation in early childhood education and care, and only 28 per cent of 4-year-old Roma children were enrolled in pre-primary education in 2011, while this rate was 74 per cent for all 4-year-olds in Slovakia. A related and consequential issue is the very high incidence of early school leavers among the Roma ( 83 per cent) (FRA, 2014).

The rigidity in curriculum-building (even after the introduction of the 2-stage development in 2009) and choice of teaching methods prevents teachers from 
being completely free to adapt the study approach and conditions even in a desegregated environment with disadvantaged pupils. In addition, the general underfinancing within the system - while Slovakia had one of the largest increases in per-student expenditure among OECD countries between 2005 and 2012 , the per-student expenditure in primary education of US\$5,415 is still well below the OECD average of US\$8,247 (OECD, 2015) - and the inflexibility of the salary system for teachers causes most teachers to seek employment at mainstream schools with higher classroom performance and fewer discipline problems, contributing partly to the low share of core-skills-resilient pupils in Slovakia.

The interplay between the market economy and post-socialist features exacerbates social processes leading to educational inequity, as in the above case of segregation. Sensing the complex nature of the educational issues and urged on by the worsening below-average results in international comparisons, the need for a more systematic reform has also been formulated at the governmental level. 'Learning Slovakia' is a government strategy finalized after a broad expert and public stakeholder consultation in 2017, consisting of an eight-chapter document covering the whole spectrum of schooling from primary to tertiary education. The document details a reform plan for a more inclusive education focusing on individualized needs backed up by an overall increased funding level, higher teacher salaries, more flexible curricula with more soft skills and practical competencies, and an advanced support system of experts, psychologists, and assistants (Ministry of Education, Science, Research and Sport of the Slovak Republic, 2017). The importance of the issues is strengthened by the work of independent non-governmental think tanks that also provide comprehensive evidence-based policy recommendations for education at all levels - see, for example, 'Learning Makes Sense' (MESA10, 2018).

The reform plans aim to give more room to implement innovative alternative and flexible educational programmes, one of which will be presented and analysed in the following section, that take into account the current developments in the education system.

\section{Assessment of a case study: theoretical background and methodological framework}

Teach for Slovakia (TFS) is an innovative model to recruit, prepare, and place university graduates with a minimum 5-year master's degree as teachers in schools serving students in need. TFS is part of the global Teach for All network that offers educational opportunities to promising future leaders in 48 countries via a 2-year teaching placement in high-need schools. The partner organizations have reached 34,000 teachers and 5 million students since 1989 (Cumsille and Fiszbein, 2015).

In Slovakia, candidates having at least a 5-year master's degree are chosen through a rigorous and competitive selection process consisting of trial lessons, 
problem-solving exercises, interviews, and appraisal at an assessment centre. Successful applicants go through a minimum 6-week 'basecamp' training, as well as a practicum in different school environments. The training consists of acquiring practical skills, didactic methods, and theoretical knowledge on how to teach in such challenging environments and how to set personal goals. Highlevel professional mentors prepare the future teachers for their eventual 2-yearlong teaching placement at high-need primary schools, and support them during the whole teaching process in terms of how to manage time and how to prioritize and streamline work.

Three cohorts have already been placed since 2014 (with around 20-30 participants per cohort) under the guidance of 17 programme teachers. In line with their preferences and matching the needs of participating schools, successful candidates are placed at primary schools in five Slovak regions (Bratislava, Kosice, Presov, Poprad, and Michalovce - Zilina will soon join the programme as the sixth region). The participating regions are selected according to the needs of the partner organizations (sponsors), and these are typically places where the level of local education hinders economic development. Currently, TFS teachers teach various subjects at 32 primary schools for around 24 hours per week, according to school needs, mostly with children from a socially disadvantaged environment. Approximately 80 per cent of the participating schools are of a disadvantaged nature, while special schools cannot participate in the programme (TFS thus promotes desegregation). For their work, the participants receive a remuneration corresponding to the average Slovak salary of university graduates at beginner positions in the private sector, which is 50 per cent financed by the ministry responsible for education and 50 per cent financed by a wide range of sponsors and supporters (private companies and individuals).

The initiative supports all participants in developing their vision for how to induce changes contributing to a fairer and better-functioning education system built around children, and networking among participants and with relevant stakeholders (public authorities, private firms, civil society, NGOs, and the educational community) has become a more relevant element within the programme since its initiation. Participants also engage in various supporting activities, such as internships with sponsors, and they serve as ambassadors after completing the period of compulsory teaching. The programme's long-term objective is that ambassadors will instigate changes from their positions at public authorities or private organizations within the education system with the help of their experience gained during the 2-year teaching practice (top-down, comprehensive system-level reform).

Based on the above characteristics, we consider TFS to be a social innovation and intend to assess it from this perspective. We acknowledge that a uniform interpretation of social innovation does not exist but can be broken down to at least three main categories: (1) definitions by purpose, (2) definitions by focus, and (3) definitions by nature (Anderson et al., 2015). A common point in these definitions is an equal focus on both the process and outcome of innovations that 
are social in both their ends and means (Ilie and During, 2012). Because the overarching theme is related to EU social inclusion policies, we use the Commission's definition of social innovation, i.e. 'the development of new ideas (products, services and models) to meet social needs and create new social relationships or collaborations. It represents new responses to pressing social demands, which affect the process of social interactions' (European Commission, 2013).

As highlighted in the previous section, broader social, economic, and political processes in connection with the characteristics of the current 'hybrid' education system (including both post-socialist and market economy aspects) transform the personal, social, or environmental traits of students into factors of disadvantage contributing to higher educational inequity and lower rates of excellence. Following the European Commission's definition above, as well as reflecting Oosterlynck et al. (2013), the research aim was to analyse how TFS facilitates processes of change towards a more inclusive and higher quality education system by satisfying unmet local needs, changing social relations, and increasing socio-political mobilization or access to resources.

The specific details on the operation of TFS were collected through a twostep process - first was an online survey, and this was followed by semistructured interviews. The focus of the survey was to gain first-hand data on the functioning of TFS. The survey comprised mandatory five-level Likert-scale questions and mostly optional open-ended questions divided into six main query groups: personal data (age, qualification, role in TFS, and region and year of teaching), characteristics of the teaching environment (local students, teachers, and related organizations), self-assessed changes in student performance, selfassessment of personal development, self-assessment of local-regional changes, and closing questions, including consent to a potential interview.

The aim was to understand the specific change processes envisaged and implemented by TFS. For this purpose, the broadest stakeholder group was targeted through key persons within the organization, who were contacted through online channels or personally. They were asked to personally disseminate the online survey sheets or provide contacts to programme participants and team members. With their support, an extensive database was assembled, and the survey was sent to 76 TFS participants in September-October 2018, out of which 20 responses were received. This low response rate can be explained by two factors - the generally busy time schedule of participants at that time (beginning of the school year) and their reluctance to answer questions about programme-level operation rather than their 'place-based' experience. The lessons learned during this process will be used when designing future surveys in a potential follow-up research project.

As a second step, to analyse TFS activities through the bottom-up teaching, administrative, and organizational experiences of a balanced group of TFS team members, the authors conducted semi-structured interviews with 10 participants. A set of open-ended questions focused on the deeper understanding of the 
change processes - including the objectives, challenges, barriers, and potential solutions - that were planned and actually implemented within the broader socioeconomic context by TFS.

The interview sample was balanced in terms of experience, qualification, functions, and regional coverage. Two interviewees were younger than 26 , six were aged between 26 and 30, and two were between 30 and 40 years. Seven of them had a social sciences background, one had studied IT, one had studied theology, and one had studied art science. Seven interviewees taught disadvantaged students only, two of them taught non-disadvantaged students only, and one taught both categories. All interviewees served as teachers, and in addition three worked as mentors, four as ambassadors, and one as an office team member and career consultant (one person could have more than one role). One interviewee had already taught in 2014, and the other teaching years were evenly distributed, with a stronger focus on recent years: four interviewees had taught in 2015, three in 2016, five in 2017, and six in 2018, thus some interviewees had already finished their 2-year teaching period, while some were still in their first or second year of teaching. Four interviewees taught in Bratislava, four taught in the Presov region, two taught in the Kosice region, and one taught in the Poprad region (Michalovce as the newest region was not represented, and one person taught in two regions).

\section{Main findings and discussion}

Every social innovation aims to satisfy social needs that are inadequately addressed by macro-level welfare policies or private actors, and in the case of TFS the aim is to strengthen access to a high-quality education for children with a disadvantaged background. The interviews confirmed such an unfulfilled need from both the provider and receiver of support because each year more schools are interested in participating in the programme than new schools admitted, and there was a ten-fold oversubscription for the teaching places available at the last selection session. Currently 25-30 schools are served with around 50 TFS teachers, and the short-term plan is to sustain this number.

The main reason for this is that TFS recognizes that educational reforms cannot be implemented even at a local level if schools are unable to use the new methods and approaches in their everyday classroom practices, as shown by Petrová and Zápotočná (2018) in relation to new early literacy education. Therefore, only such schools were admitted to the programme where the chance of sustainable cooperation to induce educational changes was higher due to the existence of a local sponsor and interested school principal or teacher community. The need for a more inclusive (desegregated) education is illustrated by one example where the newly opened 'normal' school with TFS teachers quickly became much more popular than the older, parallel-functioning special school into which most disadvantaged local children were enrolled.

There is no institutionalized channel between principals and TFS, and the cooperation relies mainly upon pre-existing contacts and ongoing networking. 
Unlike in some other Teach for All countries, principals cannot advertise themselves and unilaterally select candidate teachers for their own schools, but the areas of interest of candidates (in terms of region, subjects taught, and school characteristics) are taken account of, providing a less distant and more harmonious collaboration between TFS teachers and the local school community from the beginning. This closer initial local teacher-TFS relationship might, however, be a barrier to further outreach to other regions, and if there is a change in strategic planning a more institutionalized approach to local stakeholder engagement would be required.

Thus, TFS teachers could start their work in local environments where school leaders - and sometimes mayors - were from the beginning inclined to approve of providing the opportunity for such socio-educational experimentation, but the acceptance and cooperation of local teachers still had to be gained. The main challenge was the most efficient introduction of less textbook-oriented teaching with a focus on soft and practical skills enhancement within an established structure where the local actors show little inclination for change. The OECD (2014) shows an extremely low motivation among Slovak teachers (4 per cent felt that their profession is valued in society compared to a 31 per cent OECD average). This situation should be addressed by the new dynamics introduced by TFS if the programme intends to achieve tangible results.

In overcoming this challenge, the interviewees stressed the importance of a mutual learning process within the school environment, which first takes place from the side of incoming TFS teachers through incumbent teachers having a better knowledge of local circumstances, after which TFS teachers could also introduce their portfolio of innovate teaching techniques adapted to local school needs. Ongoing cooperation with open-minded local teachers and school leaders from the outset is crucial for developing the capacity for collective action. Interview evidence shows a variety of forms of local teacher-TFS collaboration, ranging from common out-of-school programmes and study training to the adoption of new testing approaches or curriculum adjustment within the current legislative boundaries. This substantially improves the quality of interaction with schools during the teacher practicum, the intensity and duration of which is not sufficient in the official system.

These changes in intra-school student relations were also meant to alter student-student relationships, which was of utmost importance in the case of desegregated schools where enhanced mutual trust and cooperation between disadvantaged and non-disadvantaged students was sought. The interviewees mentioned that the challenge of establishing a more positive classroom environment could be met by the practical implementation of TFS values, such as highlighting the importance of persistence, investing more effort, using innovative teaching techniques and learning strategies, and encouraging the pupils to help each other. Without the engagement of local teachers, this process could not have been successfully initiated. A telling example of behavioural change was when, after one year of TFS involvement, a class of students complained about the 
undisciplined behaviour of other classes - which was the very same behaviour that class had demonstrated prior to TFS!

One of the main problems with previous subsequent educational reform steps was the negligence of a broader socioeconomic environment. To address this and to establish a more favourable local community spirit, TFS has also aimed at more wide-scale mobilization of local community actors. Interviewees considered a high level of interaction between schools and parents to be key to achieving better study results in vulnerable communities. The challenge lies in changing the established socio-cultural pattern where disadvantaged parents consider their role in their children's education to be limited to out-of-school activities. The interviewees at segregated schools particularly underlined the relevance of building a well-functioning relationship with parents. Surveys and interviews showed that stronger mutual trust could be built with TFS support, which is a prerequisite for stronger social cohesion at the community level. Dependent on local requirements, the trust-building and parent involvement was achieved by various forms of activities, including parent consultations, withinschool programmes, and out-of-school programmes with visits to children's homes.

Moving beyond the local level, the networking and community building on a broader scale was more scattered. Based on the interviews, it was mostly personal connections that resulted in governmental organizations or NGOs interested in changing local educational conditions getting involved. All interviewees highlighted the excellent work and cooperation with these organizations; therefore, the issue of the intensity and coverage of TFS outreach lies with the quantity - and not the quality - of connections going beyond the local level. When TFS was initiated in 2014, such a broader stakeholder engagement was not an explicit aim, but the programme should a find a way to bolster its outreach without compromising existing teaching quality.

The ultimate goal of these changes in social relations, achieved by local and broader-level community building, is to empower students (and their parents) and teachers. The method by which disadvantaged students and their local community can participate in discussions on educational means and methods to satisfy their own needs is in itself empowering because it recognizes disadvantaged persons as capable as other social groups. A more child centred teaching approach lies at the core of this educational method that is adapted to local needs, based on these discussions. TFS teachers place greater emphasis on communication, critical thinking, leadership, decision-making, and opinion-making of children, shifting the teaching process from being frontal to more problemoriented and collaborative.

This challenges established patterns, and the interviewees agreed that Slovak and, in particular, disadvantaged students are not used to their opinion being sought and valued, which contributes to their suffering from social disintegration and non-resilience in the classroom setting (see Table 10.4). The OECD (2018b) shows that socially and emotionally integrated and resilient students tend to do 
better academically; therefore, such soft skills enhancement is of key importance to better study outcomes. The most frequently mentioned positive effect by the interviewees was the development of the soft skills of pupils taught in TFS classes - they better understood their rights and roles in the education system and could better express their feelings and motivations. A higher level of attitude change was noted at one school where vulnerable students were interested in being involved in the school board - currently only in an advisory role, but which could be subsequently extended.

As regards the empowerment of other actors within the school environment, such as teachers and parents, training organized by TFS team members on educational, administrative, and management issues are of relevance. The experiences of the interviewees differ concerning this capacity-building process, and some school leaders and teaching communities are more open, while others are outright dismissive. Nevertheless, based on international studies, there is a clear need for such vocational training because Slovakia has the highest number of teachers not participating in collaborative practical training among the OECD countries (43 per cent) (OECD, 2014). To overcome this challenge, the interviewees emphasized the need to build up good relations with teachers and parents from the outset.

The more practical training ensured for both students and teachers is also favourable to programme sponsors that intend to align education with local labour market needs. TFS thus strategically mobilizes public and private institutions to alter and stabilize market relations in pursuit of the mutually beneficial social goal of more-inclusive, high-quality (primary school) education. TFS contributes to increased and diversified education funding by drawing in more private finances that are otherwise inaccessible in the system. The access to more diverse funding sources favours the sound functioning of the system because a very large share of the expenditure on educational institutions comes from public sources in the underfinanced Slovak education system (84.6 per cent in 2012 compared to the OECD average of 83.5 per cent - OECD, 2015). This is in line with the statement of Oosterlynck et al. (2013) that innovative local social innovations do not per se deny the importance of a well-functioning local market economy, but rather aim to recognize and strengthen other forms of economic and non-economic agency that are beneficial for the equal satisfaction of social needs.

To our knowledge, this is the first study on the actual change processes introduced by TFS and its related potential long-term effects. The present study, which has more of a qualitative nature, will be complemented by quantitative research currently being undertaken by an external company using the so-called Panorama Survey applied in each Teach for All country focusing on students' perceptions of a specific teacher, classroom, and school atmosphere (MercerGoelden, 2017), and preliminary results have shown advances in the nonacademic progress of Slovak TFS students.

In the framework of our qualitative research, we highlight the above-detailed mechanisms aimed at mitigating the post-socialist heritage by introducing new 
ideas, approaches, and methods within the limits of the national curricula and by enhancing the prestige of the teaching profession. In this sense, TFS practices directly or indirectly contribute to most policy recommendations by the OECD (2018a), and these are also implicated in the Learning Slovakia Strategy.

Nevertheless, these processes are part of a comprehensive educational reform in line with EU social inclusion policies. Our interviewees mentioned the following as the most relevant educational issues: strengthening of early childhood education and care, further desegregation and reconsideration of the special school system, improving the attractiveness of the teaching profession (salaries and conditions), improving teachers' capacity to detect student needs and to manage diverse classrooms (e.g. specific training or use of services of specialized teachers whose beneficial effects were mentioned by more interviewees), and the official acknowledgement of TFS teaching time for minimum teacher certification.

Until such issues are properly addressed in a systematic way, the TFS programme can only act as a complementary social innovation igniting local-level changes in school environments that are ready to embrace them. The higherlevel impact of TFS is dependent upon whether the programme can fulfil its long-term objective to facilitate the substantial reform steps described above in the Slovak education system through its ambassadors, i.e. alumni in adequate private and public decision-making positions who possess the necessary theoretical and practical knowledge gained during their programme involvement. In that case, TFS might act as a catalyst for systematic changes at all levels, but until then it serves the general objective of promoting a more inclusive Slovak education system through the more limited change processes detailed in this section.

\section{Funding}

This research was carried out in the framework of national projects VEGA No. 1/0001/16 and VEGA No. 1/0367/17.

\section{Note}

1 People living in households that either live below the relative poverty line, experience severe material deprivation, or have very low work intensity.

\section{References}

Anderson, T., Curtis, A., and Wittig, C. (2015). Definition and Theory in Social Innovation. The Theory of Social Innovation and International Approaches. ZSI Discussion Paper, Nr. 33. Vienna, Austria: ZSI.

Atkinson, T., Cantillon, B., Marlier, E., and Nolan, B. (2002). Social Indicators: The EU and Social Inclusion. Oxford, UK: OUP. 
Beblavý, M. and Veselková, M. (2014). Future of Skills in Europe: Convergence or Polarisation? CEPS Working Document No. 309.

Bútora, D. and Kríž, M. (2013). Prelomené lady: Vzdelávanie zacína byt témou krajiny. In: M. Bútora, Z. Bútorová, and M. Kollár (Eds.), Odkial' a kam. 20 rokov samostatnosti. Bratislava, Slovakia: Inštitút pre verejné otázky a Kalligram.

Cumsille, R.B. and Fiszbein, A. (2015). Créme de la Créme: The Teach for All Experience and Its Lessons for Policy-making in Latin America. Education Policy Analysis Archives 23(46), pp. 1-22.

European Commission (2001). Joint Report on Social Inclusion. [online] Available at: http://ec.europa.eu/employment_social/soc-prot/soc-incl/joint_rep_en.htm [Accessed 15 October 2018].

European Commission (2005). Working Together, Working Better: A New Framework for the Open Coordination of Social Protection and Inclusion Policies in the European Union. [online] Available at: https://eur-lex.europa.eu/LexUriServ/LexUriServ.do?uri= COM:2005:0706:FIN:EN:HTML [Accessed 1 October 2018].

European Commission (2010). The European Platform against Poverty and Social Exclusion: A European Framework for Social and Territorial Cohesion. [online] Available at: https://eur-lex.europa.eu/legal-content/EN/ALL/?uri=CELEX\%3A52010DC0758 [Accessed 21 September 2018].

European Commission (2013). Guide to Social Innovation. Brussels: Regional and Urban Policy Publications, Office of the European Union.

Eurostat (2013). The Measurement of Poverty and Social Inclusion in the EU: Achievement and Further Improvements. Seminar 'The Way Forward in Poverty Measurement' 2-4 December 2013, Working Paper 25. Geneva, Switzerland: United Nations Economic Commission for Europe.

Eurostat (2018). Education and Training in the EU - Facts and Figures. [online] Available at: https://ec.europa.eu/eurostat/statistics-explained/index.php/Education_and training_in_the_EU_-_facts_and_figures.

FRA - European Union Agency for Fundamental Rights (2014). Roma Survey - Data in Focus. Education: The Situation of Roma in 11 EU Member States. Luxembourg, Luxembourg: Publications Office of the EU.

Ilie, E. and During, R. (2012). An Analysis of Social Innovation Discourses in Europe: Concepts and Strategies of Social Innovation in Europe. [online] Available at: http:// edepot.wur.nl/197565 [Accessed 15 September 2018].

Kascak, O. and Pupala, B. (2014). Towards Perpetual Neoliberalism in Education: The Slovak Path to Postcommunist Transformation. Human Affairs 24, pp. 545-563.

Kosova, B. and Porubsky, S. (2015). Slovak Republic. In: W. Hörner, H. Döbert, L. Reuter, and B. von Kopp (Eds.), The Education System of Europe, Global Education Systems. Basel, SUI: Springer.

Kovács, K. (2015). Advancing Marginalisation of Roma and Forms of Segregation in East Central Europe. Local Economy 30(7), pp. 1-17.

Mercer-Goelden, Z. (2017). A Guide to Student Surveys About Teaching. [online] Available at: www.panoramaed.com/panorama-student-survey [Accessed 21 September 2018].

MESA10 (2018). Learning Makes Sense. [online] Available at: https://en.todarozum.sk/ [Accessed 22 September 2018].

Ministry of Education, Science, Research and Sport of the Slovak Republic (2017). Učiace sa Slovensko. [online] Available at: www.minedu.sk/data/files/6987_uciace_ sa_slovensko.pdf [Accessed 16 October 2018]. 
Németh, S., Nevsija, D., Oláhová, B., and Garáž, S. (2014). Advancing the Education of Roma in Slovakia - Ref Country Assessment 2014. Roma Education Fund, Slovak Country Assessment.

OECD (2013). PISA 2012 Results: Excellence Through Equity: Giving Every Student the Chance to Succeed (Volume II), PISA. Paris, France: OECD Publishing.

OECD (2014). A Teachers' Guide to TALIS 2013: Teaching and Learning International Survey, TALIS, OECD Publishing. [online] Available at: http://dx.doi.org/10.1787/ 9789264216075-en [Accessed 15 October 2018].

OECD (2015). Education Policy Outlook - Slovak Republic. OECD Publishing, Paris. [online] Available at: http://dx.doi.org/10.1787/9789264232178-en [Accessed 1 October 2018].

OECD (2016). PISA 2015 Results (Volume I): Excellence and Equity in Education, PISA. OECD Publishing, Paris. [online] Available at: http://dx.doi.org/10.1787/9789264266490en [Accessed 1 October 2018].

OECD (2018a). Education at a Glance 2018: OECD Indicators. OECD Publishing, Paris. [online] Available at: http://dx.doi.org/10.1787/eag-2018-en [Accessed 21 September 2018].

OECD (2018b). Equity in Education: Breaking Down Barriers to Social Mobility, PISA. OECD Publishing, Paris. [online] Available at: https://doi.org/10.1787/9789264073234en [Accessed 22 September 2018].

Oosterlynck, S., Kazepov, Y., Novy, A., Cools, P., Barberis, E., Wukowitsch, F., and Leubolt, B. (2013). The Butterfly and the Elephant: Local Social Innovation, the Welfare State and New Poverty Dynamics. ImPRovE Discussion Paper 13/03. [online] Available at: http://improve-research.eu/?wpdmact=process\&did=MjAuaG90bGluaw [Accessed 16 October 2018].

Petrová, Z. and Zápotočná, O. (2018). Early Literacy Education in Preschool Curriculum Reforms: The Case of Post-Communist Slovakia. Global Education Review 5(2), pp. 145-159.

Schoukens, A., de Becker, E., and Beke Smets, J. (2015). Fighting Social Exclusion under the Europe 2020 Strategy: Which Legal Nature for Social Inclusion Recommendations? International Comparative Jurisprudence 1, pp. 11-23.

Siskovic, M. and Toman, J. (2015). OECD Review of Policies to Improve the Effectiveness of Resource Use in Schools. Country Background for the Slovak Republic. Bratislava: Educational Policy Institute.

Zelina, M. (2005). Vzdelávacia politika o rozvoj skolstva po roku 1989 v Slovenskej republike. Technológia Vzdelávania 13(6), pp. 4-6. 


\title{
The integrated approach in practice: a framework for Roma work inclusion. Case studies from Romania
}

\author{
Theofild-Andrei Lazăr and Melinda Dincă
}

\section{Introduction}

Despite the adoption of targeted European and national policies, the Roma population in Europe still faces some serious challenges in accessing and securing proper employment and subsequent increases in their welfare and autonomy. A recent evaluation of the labour market outcomes of national strategies for Roma persons' inclusion at the European Union (EU) level (EC, 2018b) shows that, out of four indicators analysed, only one displayed progress between 2011 and 2016, with 'discrimination when looking for work' being reduced, but the number of 'Roma in paid work' stagnated, and the last two indicators - 'young

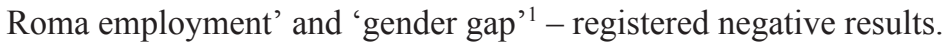

At the European level, on average only one in ten Roma has paid employment (Bernat and Rahman, 2014). A similar situation is found in Romania, where only 13 out of 100 Roma work full-time with a work contract (FRA, 2016). This massive exclusion from the labour market perpetuates the vulnerable state of Roma (Nasture, 2005; Messing, 2013) by reducing their opportunities for social and economic development (Anton et al., 2014).

The main barriers identified by most of the studies focusing on the labour market inclusion of Roma persons are (i) the widespread discrimination on the labour market (Messing, 2014) and (ii) the low levels of education ${ }^{2}$ and poor marketable skills that characterize a large proportion of the Roma population (Anton et al., 2014; Bernat and Rahman, 2014), and which are not compatible with the increasing and diversifying demands of the contemporary labour market. Additionally, the Romanian context presents a series of structural characteristics that contribute to low levels of work inclusion of Roma persons: being a predominantly young population, ${ }^{3}$ they are disproportionally affected by the low levels of employment that generally characterize the youth. ${ }^{4}$ Additionally, Roma persons in Romania are found to a larger extent in rural areas, where the employment opportunities are much scarcer than in urban areas (Anton et al., 2014).

In order to increase the effectiveness of the programmes for Roma work inclusion, the need for assessing the transformative potential of past initiatives is 
extremely important because it allows for building present or future interventions based on this knowledge in order to improve their chances for success (Nasture, 2005; Baciu, 2017).

This chapter aims to advance the integrated approach as a suitable framework for addressing in practice the challenges raised by complex social problems by providing the reader with an explanation on the why and the how of our proposed approach's value and use in the design and implementation of interventions addressed to the work inclusion of Roma persons. The concept of 'inclusion' is preferred to 'integration', Roma work inclusion being the act of making Roma citizens feel valued and belonging in a working context, not simply incorporated into such a context. Inspired by Brewer's Optimal Distinctiveness Theory (Brewer, 1991) Lynn Shore and her colleagues define inclusion in the work place as 'the degree to which an employee perceives that he or she is an esteemed member of the work group through experiencing treatment that satisfies his or her needs for belongingness and uniqueness' (Shore et al., 2011).

We argue that the integrated approach is appropriate for this task because of the increased complexity of the problem it tackles ${ }^{5}$ and because of the positive results documented through empirical evidence obtained by the interventions that have used it. In taking this approach, we employ different levels of analysis (diachronic and synchronic, top-down and bottom-up) and various conceptual frameworks (trust, person-in-situation, multi-level approach, social networks) inspired from fields that address issues related to social inclusion, social equality, and equity in contemporary society. Although we evoke various theories that ascribe the topic of this chapter, our undertaking is not theoretical per se, but rather uses theory as an argumentative tool to show how the roots of this approach to practice are strongly immersed in a solid theoretical background.

The chapter starts with an overall presentation of the integrated approach as a practical framework in addressing issues of vulnerability, and the main theories and concepts underpinning the approach are discussed. We continue with a short description of the dynamic of the Roma persons' situation on the labour market in post-communist Romania. Thus, the first part of the chapter is designed to advance the arguments on why we consider the integrated approach to be instrumental for interventions addressed to the work inclusion of Roma persons.

The second part of the chapter is dedicated to presenting arguments on how the use of the integrated approach can effectively tackle the challenges associated with the work inclusion of Roma persons and can produce valuable results. The discussion is based on two case studies of interventions addressed to the work inclusion of Roma persons, from which we extract examples of direct actions undertaken with the target groups based on the methodology prescribed by the integrated approach. The last section of the chapter reiterates the advantages of the approach in the interventions dedicated to enhancing opportunities for vulnerable groups. 


\section{The integrated approach - as a framework for intervention with vulnerable persons}

Recently, the integrated approach was highlighted to be an effective strategy towards Roma inclusion in several reports addressing issues of Roma social inclusion (Anton et al., 2014; EC, 2018a). The concept has its modern origins in the term 'integrated care' as used in health services. In fact, the health system had an important contribution towards the promotion of the integrated approach targeting vulnerable sectors of the population. Practitioners and researchers started to notice that the fulfilment of the medical needs of the patient was merely a small part of their overall recovery process (McGinnis et al., 2014). The 'integrated care' approach has been described as an efficient multidimensional intervention that includes services adapted to the specific needs of the clients (Nies and Berman, 2004: 12).

Based on social systems theory (Parsons et al., 1988), the integrated approach in social services acknowledges the need for a multilevel systems intervention that connects the inputs of various support systems and generates a combined action targeted towards reducing or solving a specific problem. The concept has gained value and popularity in redefining social services delivery mainly in the European political discourse as a means for social innovation in the context of the economic crisis from 2008 (Milotay, 2016). The 'integrated services' are conceptualized by the EU project ProCare as a way of providing tailored services by different institutions in a coordinated manner in order to improve the services' quality and cost-effectiveness, the purpose being to increase the level of satisfaction for both beneficiaries and professionals involved in the processes (Leichsenring and Alaszewski, 2004: 15).

McGinnis et al. (2014) advanced the following three mandatory elements for implementing the integrated approach in new social contexts: (1) the creation of entities responsible for the coordination and management of the collaboration across services, (2) the implementation of a formative evaluation system that can track and measure the outcomes, and (3) clear financing rules that include rewards for effective service integration.

The integrated approach provides a series of clear advantages, mainly when targeting complex social problems, and observers note that this approach results in better resource allocation and is able to achieve more with fewer resources (Fine et al., 2000; Munday, 2007; McGinnis et al., 2014; Milotay, 2016). The supporters of the integrated approach have strong arguments regarding the quantity and quality of the outcomes, both for the clients and the entities that implement the approach. From the client's perspective, the effectiveness is emphasized starting from better access to assistance (Fine et al., 2000), continuing with better needs assessment and response to the complexity of the situation (Munday, 2007; McGinnis et al., 2014; Milotay, 2016), and finally to providing qualitative care and increased user satisfaction through highly adapted and complete services (Nies and Berman, 2004). From a societal perspective, the integrated approach contributes to 
simplifying the implementation of national, regional, and local strategies through shared expertise and actions (Milotay, 2016) and to the strengthening of the community's capacity to respond to their members' needs through the development of local networks (Geinger et al., 2015). No less important, the integrated approach can 'lead to innovation and streamlining of service delivery' (Fine et al., 2000) through the professional communities that it creates.

However, one of the main disadvantages would be that the implementation of the integrated approach is time consuming and involves some 'transaction costs' (ibid.). Additionally, the change from a specialized social services system delivery to an integrated one needs time to develop. Policies and strategies need adaptation, professionals need qualification, the networks need to be created, and action plans need to be developed, including collaboration protocols and monitoring instruments. Besides the initial costs of development and the normal costs of functioning, the integrated approach also generates administrative and organizational costs for keeping the networks functioning.

\section{The Roma population's income sources in post-communist Romania}

The Roma population in Romania currently represents one of the largest ethnic minorities. The latest national census registered 621,600 Roma people, corresponding to 3.3 per cent of the total population (2011 Population Census). Other estimates show the Roma population at around 2 million citizens, representing 10 per cent of the total population (FRA, 2011; Anton et al., 2014).

Over the past three decades, European countries have faced major social, economic, and political changes. In Romania, after the fall of the communist regime, economic and social policies were marked by numerous socioeconomic changes and demographic shifts related to the transition to the market economy, including private property relations, economic reactivity in relation to the demandsupply dynamics of the free market, the decentralization of the state economy, industrial privatization, land and buildings retrocession, entrepreneurship, and private capital investments (Zamfir, 2004). As the new democratic society emerged, individual rights and liberties, including those of the ethnic minorities, gained more and more importance, at least within the legislative framework. But even so, the prejudice and persecution of Roma continued as social and economic insecurity started to grow, accompanied by trends of nationalism in second place. The 1990s were characterized by widespread discrimination, negative stereotypes, hostile attitudes, and even violence against Roma persons (CEDIME-SE, 2001:11).

The restoration of the right to property was a tedious process that began in 1990 with the abolition of the Collective ${ }^{6}$ and ended with the Ownership Act of 2005. ${ }^{7}$ Because the majority of Roma did not receive any land after the restoration of the right to land property, a major part of Roma people from the rural areas became daily workers, tried to find an income source from informal 
occupations elsewhere in the region, or migrated abroad. In the urban areas, many Roma lost their jobs due to the collapse of industry and massive layoffs that followed in the first decade after the '89 Revolution. ${ }^{8}$ Roma's vulnerability on the labour market was amplified by the inexistence at the time of an effective social protection system. Due to the fact that prior to 1989 employment was compulsory, the post-communist period debuted with little preoccupation for issues like unemployment or poverty, and there was no insurance system or a social protection system to counteract the economic effects on the population (Preoteasa, 2008: 56).

In the 1990s, more than 60 per cent of Roma persons were living below or near the poverty line. Some Roma agricultural and manufacturing cooperatives had been initiated, but they were exceptions rather than the rule (Braham, 1993). Even though according to the Romanian constitution discrimination was forbidden - regardless of ethnicity, gender, or religion - employment discrimination of Roma was still present, and work-related legislation in this area was severely lacking (Weber, 1998). Human rights organizations and non-governmental organizations (NGOs) for Roma monitored and reported discrimination against them in the process of finding a job or at the workplace. A multitude of situations have been reported about employers discriminating against Roma, many newspaper announcements for available jobs specifically exclude Roma applicants, and it is common practice of first getting rid of Roma employees when layoffs are made (CEDIME-SE, 2001).

In 2002 more than a half of the Roma population was living in severe poverty, compared with 9 per cent of the total population in Romania living under the same conditions (CASPIS, 2003). In 2007 the employment rate of the Roma population was 19 per cent, significantly lower than the overall employment rate, which was 58.8 per cent. In 2010, 93 per cent of the Roma population had an income corresponding to the minimum wage or less.

After another decade, progress towards Roma inclusion is still modest. Although poverty rates are declining, social exclusion persists for Roma, and the provision of integrated services targeted to disadvantaged groups is low (EC, 2018c: 2). Employment and activity rates for Roma still remain below the national and EU average. In 2016, 'only $17 \%$ of Roma women and $49 \%$ of Roma men reported to have engaged in "paid work". The discrepancy is more pronounced in Romania than in peer countries on average' (FRA, 2016: 100). The 2018 European Commission's country report on Romania emphasizes that for Roma 'residential segregation, forced evictions and discrimination at work persist. While the specific bodies dealing with Roma show more commitment, their impact depends on the work of other institutions. Measures addressing Roma inclusion are mainly supported by externally-funded projects' (EC, 2018c: 27).

Currently in Romania the legal framework, strategies, and social policies for Roma inclusion are favourable, but the gaps between central institutions and local authorities and the lack of sustainable institutional partnerships considerably reduce the direct impact on Roma beneficiaries (Anton et al., 2014; EC, 2018d). 
The creation of the post-communist welfare state in Romania was shaped, the same as in other East European countries 'in a mode of emergency policymaking' without having any previous models of transition from communism to democracy (Offe, 2010). The process was influenced by a multitude of factors, some resulting from the communist period, some specific for the transition period, and some related to the actual socioeconomic context. This conglomerate of influences resulted in a social service delivery system with fragmented responsibilities between institutions, a lack of clear coordination bodies, and no sustainable monitoring or evaluation of the impact (Scutaru, 2017).

The Europeanization of social policies (Fenger, 2007) was strongly influenced by the EU accession process, compelling Romanian authorities to create and implement a series of targeted measures towards the social inclusion of Roma citizens and important EU funds were allocated in support of this. This way the Roma ethnic group 'was no longer regarded as solely an Eastern European problem, but a collective and general European concern' (Boscoboinik, 2006: 95).

The current Strategy of the Government of Romania for the Inclusion of Romanian Citizens Belonging to the Roma Minority (for the period 2015-2020) defines the roadmap for public policies in the area of the social inclusion of Roma. Even though all four Romanian Government strategies for Roma Inclusion $^{9}$ were extensively criticized ${ }^{10}$ (Cace et al., 2011; EC, 2018b), they represented the main programmatic documents on Roma inclusion and constituted important steps towards the development and creation of programmes, networks, and specific projects in support of the social integration of Roma people.

\section{The use of the integrated approach for improving work inclusion of Roma}

Two successful initiatives undertaken in Romania with positive outcomes on the work inclusion of Roma will be used to exemplify the advantages of the integrated approach. ${ }^{11}$ The case studies are extracted from a series of ten successful models on work inclusion gathered for the last stage of a three-year qualitative research initiative at the national level. Based on interpretative theories and using the method of institutional ethnography (Smith, 2005), the research included several phases of data collection, consisting mainly of in-depth interviews with Roma persons, public officials, NGO representatives, employers, and other relevant institutional actors. Later, aiming to identify the mechanism by which the barriers to employment are overcome at the institutional and individual level, ten case studies on successful social interventions were selected for further analysis. The analysis was performed through a sociological investigation based on non-participating direct observation, document analysis, and semistructured direct individual interviews with representatives of the institutional actors involved, the direct beneficiaries of the interventions, and the local stakeholders. The aim of the analysis was to: 
improve the current understanding of what is considered as successful intervention when working with vulnerable groups, for their work inclusion, what particular factors influence and shape an intervention into a successful one, and which ones among these factors could be replicated in the future, so as to ensure the multiplication of such successful interventions.

(Baciu, 2017: 158)

The two case studies presented below were selected based on their illustrative value on the use of the integrated approach in the interventions dedicated to the work inclusion of Roma persons.

The first selected initiative is the Ruhama Foundation's Intervention at the Colony from Telechiu (hereafter, RICT).

Telechiu is a small village situated in north-western Romania with a population of 820 citizens, among them approximately 20 per cent being of Roma origin. Roma inhabitants live in a close-knit community named the 'Colony', located $1.5 \mathrm{~km}$ from the centre of the village in a residential area that is spatially segregated from the rest of the village by a belt of empty land. Spatial segregation from the village centre, the riverside location, the small size of houses compared to the number of household members, the lack of agricultural land and of domestic animals, the unpaved roads, and the streets filled with children and adults gathering in front of the houses all outline the typical image of a poor Roma community living in conditions below the poverty threshold of Romanian rural communities. Currently, the Roma community from Telechiu leads a better life than it did ten years ago, when the Ruhama Foundation engaged with the community and managed to direct the attention of the local authorities towards the living conditions of Roma people living in the Colony. Today, in terms of infrastructure, most households have electricity and access to public water supplies, as well as access via gravel roads. Moreover, some houses in which the poorest families in the community used to live have been demolished and rebuilt, and other houses properly rehabilitated. However, the most visible building within the entire community is the Community Centre, built within the framework of the A Good Start Project ${ }^{12}$ financed by the Roma Education Fund and the World Bank. The Community Centre building, located in the core of the Colony, is owned by the municipality and the personnel working at the Centre are hired from the local Roma community. The Community Centre addresses the Roma community directly, organizes activities, and offers various services free of charge, including a day centre for early education and care, a nursery, counselling on hygiene and parenting issues, access to showers for adults and children, access to baths for preschool children, access to washing machines supplied with water, adult literacy classes, after-school services, support for obtaining social benefits, access to employment and work mediation services, and children's enrolment in school. Equally important, the Community Centre was established as a link between the Roma community and the local authorities in Telechiu. Even though childhood early education was the main priority in 
which the most progress has been made in improving the situation of Roma, the integrated and targeted approach focused explicitly on Roma persons' needs has had various benefits, with employment and health in focus. One of these benefits was the successful labour market integration of more than 50 Roma from Telechiu. In fact, the greatest benefit to the community is the direct and sustained involvement of the Ruhama Foundation, which facilitated the concerted efforts of various local institutions and local and regional stakeholders that made these structural changes possible within the community.

The second example is Romano ButiQ (RBQ), an entrepreneurial initiative that draws on traditional Roma skills and crafts to help communities support themselves and to market their products. The programme was selected as one of the ten finalists in the European Social Innovation Competition in 2013. Initially started in 2010 as a three-year EU-financed project implemented by a partnership of five private bodies, the programme continues to be active today as a standalone programme. The project supported Roma craftsmen in developing self-sustained social economy units by providing training in business administration, public relations, social entrepreneurship, fund raising, sales and marketing, and in designing quality products and placing them on the market. An online distribution platform was created, and various events were organized for product marketing. The project's design focused on the specific needs of the targeted groups and adapted its activities to those needs. An initial assessment of the beneficiaries' situation was conducted through on-site research. Skills testing on the targeted groups was organized in order to identify what types of products each participant could create. This bottom-up approach has proven to be successful mainly because it takes into consideration the specific issues of the targeted group. ${ }^{13}$ The major challenge was to get the craftsmen to create and design products that have demand on the market. Initially, any product of any quality was remunerated, without a time limit for completion. The quality requirements were introduced gradually, from the production of already known objects to those that can be competitive on the market. The form of collaboration was also adapted. For example, the pay-per-product method was found to be preferred by the beneficiaries, and it gave them a high degree of independence, but also motivated them to produce more to earn more. In order to increase the effectiveness of the production activities, cooperatives of craftsmen were organized at the local level with the support of local stakeholders that work through a consultative network in more than 30 communities. The role of the cooperatives is that of handling legal and fiscal requests, aspects that were difficult to deal with before for most of the craftsmen. The main results of the initiative included the establishment of 33 craftsmen cooperatives and 150 Roma becoming social entrepreneurs (Chirițoiu, 2013). Today RBQ connects over 100 craftspeople with an online market.

Taking into consideration the main characteristics of the integrated approach from the literature and the findings from the research initiative on the good practice models mentioned above, we propose and analyse the following four core 
elements that have the potential to improve the work inclusion of Roma persons: (1) coordinated interventions implemented in networks; (2) individualized interventions based on needs assessments; (3) multi-level interventions; and (4) interventions based on trust and close relations with the targeted groups.

\section{Coordinated interventions implemented in networks}

Using networks to achieve social change through employment can increase the chances for success for the following reasons: (1) increased resource availability; (2) increased cost-efficiency of the allocated resources; (3) extended expertise availability; (4) increased adapted actions at the community level; (5) increased positive perception from the community; (6) and increased solidarity and trust at the community level.

Also referred to as the 'interorganizational field', working within networks was defined as 'the relationships between different services as consumers are required to make use of assistance that is only available from a variety of otherwise autonomous, or independently functioning, agencies' (Bruner, 1992 apud Fine et al., 2000). In 2004, Warmington et al. introduced the term coconfiguration in a study about interagency collaboration. Co-configuration means that professionals from different organizations form communities of practice. The forming of networks was also categorized as multi-agency activity (Atkinson et al., 2007). There are three dimensions of multi-agency activity: organization - the adaptation of the organizational structures to the specifics of working in networks, joint investment - shared vision and common goals, and integration - the compatibility of the team members (ibid.).

Network creation leads to increased community capacity for problem-solving (Graddy and Chen, 2006) in a broad variety of situations, being especially needed when targeting vulnerable categories of the population that face a multitude of social risks. Working within networks has been shown to be a core recommendation in various international studies and reports (Fine et al., 2000; Nasture, 2005; Bodewig and Kurekiva, 2009; Froy and Pyne, 2011) and has proven to be a strong asset in the investigated good practice models from the following two main perspectives:

1 Joining resources has proven to be a gainful approach, with the initiatives being able to provide more qualitative and sustainable services for their beneficiaries. In the RBQ initiative, the craftsmen cooperatives were developed and sustained by developing local networks with the support of local stakeholders. Local authority resources were made available to support the efforts of an NGO, making their initiative sustainable and reducing the costs for implementation. Also, in the RICT study case the local authorities, the County Employment Agency, and other regional level institutions, including students and professors from two universities, worked together in designing and implementing the development activities dedicated to the 
Colony members. Networks brought together entities with different expertise that made complex interventions possible.

2 Public-private partnerships have been proven to contribute to the sustainability of the results. NGOs have limited resources, and their activity is determined by the existence of donors and the governmental and EU funds that they are able to access. Thus, long-term interventions are hard to maintain. Local authorities or other regional or local stakeholders can assure the sustainability of the intervention's results and long-term impact by prolonging the initiatives that prove to be beneficial for the community. RICT, for example, was initiated by an NGO that formed fruitful partnerships with the local authorities, public institutions at the county level, and employers from the region. Its role proved to be crucial, both by providing resources and logistical support and through direct interventions, such as attracting employers in the region or infrastructure works, financing full-time professionals working at the Community Centre, and expanding the full-time nursery and kindergarten organizational charts with new teaching positions. The good collaboration between the public and private parties also had positive changes on the public body, with the NGO's expertise on accessing different funds also supporting the local development strategy priorities.

\section{Individualized interventions based on needs assessments}

When addressing the social inclusion of vulnerable categories of the population, it is imperative to consider their specific needs (Nasture, 2005) and to be able to adapt the services to them in order to increase the chances of successful interventions. Also known as the 'person-in-situation' concept in social work practice (Turner, 1996; Cooper and Lesser, 2002), the emphasis is on considering the complexity of both individual and contextual aspects in the social support processes of the individuals in need.

Roma face a multitude of barriers to work inclusion. Most of the funding programmes for the work-inclusion interventions for Roma in Romania do not allow too much leverage for adapting actions to specific needs, and this also means low efficacy. For example, an official report ${ }^{14}$ shows that from a sample of ten financed programmes that aimed for the development of social measures for work integration of vulnerable groups, a total of 15,572 Roma persons were reported to be targeted within these programmes, from which only 3,204 (20.57 per cent) participated in qualification courses, 486 (3.12 per cent) were certified after these courses, and only 257 (1.65 per cent) were reported to be integrated in the labour market. The weak results might be due to a variety of reasons, but all are related to not addressing the specific needs of the target groups in order to motivate them and to make the process easier and more accessible to them. One relevant example is that according to Romanian legislation most of the qualification courses offered through these projects require a certain education level - at least eight grades - and this aspect has eliminated an important part of the 
potential beneficiaries, those with lower education levels, and thus is an example of the lack of adaptation to the specific possibilities and characteristics of the targeted groups. Thus, the top-down design of the services rarely proves to be successful towards Roma inclusion (Messing, 2013).

RBQ's design concentrates on the specific needs of the targeted groups and adapts its activities in order to ensure that the beneficiaries gather positive experiences during its implementation. First, an initial assessment of the beneficiaries' situation is conducted through on-site research. Performing an initial assessment of the individual, group, or community before developing services leads to better-suited interventions (Milner et al., 2015: XII). Second, skills testing on the targeted groups is organized in order to identify what types of products could be created. Besides the objective evaluation of needs, in many interventions addressed to them, what minorities want is often neglected (Zimmermann et al., 2007). Adapting to the specific needs and to the particular skills and competences of the targeted groups can be in many cases considered as optional, or too difficult, but, as in the RBQ example, this can lead to visibly better results. Designing project activities based on the assessment of the actual skills and entrepreneurial capabilities of the direct beneficiaries, including their limitations, allows for the adaptation of future actions based on these observations. Implementing the change, in this case increasing the quality of the products created by the craftsmen, was performed gradually by considering the particular context and the initial situation. This needs-based approach has proven to be successful, with around 30 Roma traditional craftsman managing to produce in the end traditional but premium products that have been sold as unique art objects with a significant added value. The individualized approach based on a thorough needs assessment increases the chances for professional inclusion of Roma persons, and RBQ thus represents a good example from the perspective of needs-based adaptation of activities.

\section{Multi-level interventions}

The individual in need is seen as part of a specific situation or context, and the intervention must consider the complexity of different aspects that can influence the process. The structural problems that Roma are confronted with are those for which no solution can be found solely by the person's own means or with the support of the informal resource systems. They are the result of extreme poverty in Roma communities, including limited access to health services, education, and the labour market and an underdeveloped infrastructure. With the appropriate involvement of the local administration, local institutions, social services providers, local and regional employers, NGOs, and local intervention groups, solutions can be found to a great number of such issues concerning livelihood. Having access to the public transport network in the vicinity, you can reach your workplace or your school more easily, and not being discriminated against will increase the chances to find and keep a job. The work integration process must 
be accompanied by other 'flanking services' (EAPN, 2017) in order to obtain gainful and sustainable results.

Even though the National Strategies for Roma included multi-level approaches to specific problems related to Roma citizens' social inclusion, the lack of clear and stable action plans, structures, and financing means that most of the initiatives targeting Roma were undertaken through projects financed by the EU or other international financing bodies. And even though excellent and much-needed initiatives were implemented, without a sustainable multi-level social policy supporting the integration of their results, their efficacy and longterm impact is reduced.

The successful practice models investigated in this study address the issue of labour market inclusion of Roma in a multi-level manner by not limiting their services only to the specifics of work integration. The RICT example used interventions on multiple levels, including early childhood education and care services, dropout prevention for primary school pupils, adult education and lifelong education workshops, home visits, medical support through mobile medical campaigns, mediation of access to the public healthcare system, hygiene and health education sessions focused on family planning, immunizations, material support to ensure school attendance, and facilitation of the work integration process for Roma employees, and it provided support in obtaining legal documents, ${ }^{15}$ holding meetings and gatherings, opening a Community Centre in the Roma living area, holding community-motivation events, and providing work-integration mediation services. This multi-level intervention has strengthened and increased people's knowledge and parenting skills, increased families' abilities to interact with institutions and employers, improved social integration and solidarity practices within the community, and supported a healthier lifestyle and access to education and the labour market. The organizers also involved the public authorities in charge of the area, thus developing positive relationships between the Roma and the non-Roma locals and strengthening the capacity of local institutions to address the issues of vulnerable groups. Also, in order to ensure the sustainability of the multi-level intervention results, partnerships were developed with employers, the local authorities, and county and regional institutions in order to obtain formal approvals, to cover future expenditures, to ensure employment contracts, to lease contracts, and to monitor, correct, and evaluate the results of these framework conventions between institutional partners.

When targeting change for vulnerable groups that face an increased number of social problems, tackling one of them only is unproductive in general for the social situation and in particular for the specific problem being addressed. Also important from this perspective is the recommendation for more flexible funding opportunities that consider the complexity of the social situation of Roma and that allow for multi-level interventions that support the process of inclusion as a whole, not as targeted measures concentrating only on employment in order to ensure success. The final goal of the multi-level intervention is capacity building 
in order to ensure the sustainability and independence of the targeted group (Nasture, 2005).

\section{Interventions based on trust and close relations with the targeted groups}

In his 2001 literature review on the concept of trust, Locke showed its important contribution from a variety of perspectives, including economic development and prosperity, good government, schools, and healthcare. He also emphasized the potential of trust to reduce ethnic conflicts (Locke, 2001). From a sociological perspective, trust 'is the product of long term, historical patterns of associationism, civic engagement, and extra-familial interactions' (ibid.). Communities that often face inequality within their structures are less likely to grow trust (Rothstein and Uslaner, 2005). A strong asset for social interventions for Roma is the setting up of generalized trust, which is a form of trust that extends "beyond the boundaries of face-to-face interaction and incorporates people who are not personally known' (Stolle, 2002: 403). The narratives of the Roma persons investigated in various studies show that the level of trust in people that are from outside their community is extremely low (Anton et al., 2014; Lazăr, 2016) and that close interactions with familiar people in turn support sustainable social inclusion activities (Breimo and Baciu, 2016; Baciu, 2017).

When managing a diversity of cross-ethnic networks, one's trust in the general population starts to form and grows in positive correlation with the networks' size and the intensity of the interactions. However, in the cases of persons belonging to discriminated ethnic groups, the concept of generalized trust can be difficult to activate with the fear of being discriminated against in some future context remaining part of the individual's fears (Lazăr, 2017). Trust can be developed but particularized by person or group.

From the RICT study case, the direct approach of the organization that activated a segregated Roma community, with immediate and direct support to the people, opened the individuals up to collaboration in order to make positive changes. In that scenario, even though the interviewed locals remember the institutional help process, they mainly recall the persons who helped them, not the institution. The presence of a trusted organization within the social network of individuals, especially in a segregated community, can lead to important positive effects. The narratives show a variety of important changes, from improving living conditions, to enrolling in school, job qualification, and employment. In close relation with trust, another aspect identified as relevant in the successful models analysed here is the emphasis on the interpersonal and direct interactions between the professionals and the beneficiaries. The involvement of formal and informal leaders from the communities where the activities were implemented resulted in increased participation in the RBQ case as well. Implementing activities in the community with the support of persons who already have a close 
relation with the communities led to positive responses from the beneficiaries and increased the effectiveness of the action.

\section{Conclusions on the use of the integrated approach when working with vulnerable groups}

Roma people are one of the most discriminated against and socially and economically marginalized groups in Romania and in Europe. Considering the complexity of their current social and labour market situation, it represents an appropriate step to assess the effectiveness of the integrated approach as a way of dealing with difficult social issues. The four elements introduced above provide key actions for improving the support services delivery system, especially in societies that are still based on highly centralized and specialized structures. Romania is a good example from this perspective, still having almost 30 years after the fall of the communist regime a social service system that is deeply influenced by the past, including state-controlled services, increased bureaucracy, and concentration on offering support for wage earners (Tache and Neesham, 2011), all reducing the impact on supporting vulnerable categories such as Roma.

Transitioning to working within networks is not an easy task, and a high level of commitment is needed from the stakeholders involved in the process. As a first step, an entity responsible for the coordination and management of the collaboration across services should be created (McGinnis et al., 2014). Due to the high level of interdependency between the actors involved, building determination, motivation, and trust in the approach must follow. Along with the costs involved, restructuring is always hard, especially when addressing long established and complex systems, and thus openness to new experiences, change, and innovation promotion are mandatory conditions for the transition to an integrated system of social services delivery.

The change from standardized services to those based on specific needs assessment and client capabilities is also difficult. In this case, the relevant prerequisite is to prepare the practitioners for a new way of working. In the traditional arrangements of social service delivery systems, as is mostly the case in Romania today, the institutions are based on specific labour divisions and specialized tasks, with professionals being trained under a system that promotes specialization. Change could start from the educational institutions, with adapted curricula that promote an integrated approach.

Finding solutions to complex social issues, such as the work inclusion of Roma people, implies multi-level interventions in order to respond properly. The change from this perspective can be supported by creating synergies between different policies and systems. For example, employment and educational policies and measures can contribute greatly to the efficacy of the measures towards the work inclusion of Roma (Anton et al., 2014). The coordinators might rely on the existing social services delivery system by establishing partnerships based on 
their already proven competencies. ${ }^{16}$ From this perspective, rural communities have a disadvantage in that for most of them the local authority is the only organization delivering social services. But even in these cases, active local authorities can attract NGOs and county-level institutions in supporting their efforts.

Supplementary to the four elements, the transformative actions should be accompanied by the creation of a formative evaluation system that can track and measure the outcomes. Following the European and National Social Inclusion Strategies, clear goals should be formulated in addition to and in congruence with action plans and ensuring that financial resources and human resources are available for implementing these action plans, a monitoring system created and implemented by the national and regional coordinating bodies, and an independent evaluation report prepared that measures the impact and the sustainability of the results and promotes the guidelines for future social policies and interventions. The integrated services are difficult to evaluate because they are created from the bottom up, they are outcome-oriented, and they are fitted to respond to local and individual needs. These issues regarding the evaluation can be solved by implementing community-based systems of monitoring and evaluation, with local-level actors being those who best know the needs and can easily give feedback due to direct motivation and close proximity (ibid.).

Finally, clear financing that includes rewards for effective service integration represents the third element, and clear and predictable financing might come from the government as part of a national priority. The successful social inclusion of Roma -- the problem for Romania -- has been extensively discussed, both from the social perspective (de Laat, 2012) and the economic perspective (World Bank, 2010; Anan et al., 2014). Thus, as a first step to a sustainable integrated approach, the programmes for Roma inclusion must be integrated into the general local development strategies (Nasture, 2005). The allocated funds can be transferred to the interested parties in multiple ways, including as incentives per outcome in the community, the money being transferred through the local authorities, or as financing grants that promote local or regional partnerships for delivering integrated services towards Roma citizens. Also, local authorities in localities with large numbers of Roma inhabitants can provide stable financing considering the social integration of Roma citizens as a local priority. Accessing various external financing sources ${ }^{17}$ also represents an important source of funds. The difficulty arises from the fact that such funding sources rarely permit an integrated approach and from the lack of continuity if the sustainable benefits and partnerships rely exclusively on external grants. The sustainability of an integrated intervention depends on identifying funding opportunities after the implementation period. If the intervention has a continuity plan, with a tight network of inter-institutional partnerships, the further funding is expected to be provided by the local authorities and to be monitored and evaluated by the active local groups and by representatives of regional or national institutions. 
Looking back on this brief description, the integrated approach seems complicated, expensive, and time consuming to initiate. But there is also evidence that such an approach is effective, long lasting, and mandatory in today's dynamic societies where the complexity of the social contexts must be accompanied by innovative and adapted interventions. An issue for further discussions considering the vulnerabilities that affect Roma is to determine whether the integrated approach should be applied as clearly targeted measures towards Roma men and women (Anton et al., 2014) or if the focus should be on addressing vulnerable categories of the population in general (Messing, 2014).

\section{Notes}

1 As the difference between the employed Roma men and women.

2 The FRA Roma Pilot Survey from 2011 shows that 24 per cent of adult Roma, compared to only 1 per cent of non-Roma, have never been to school, and 68 per cent of the adult Roma left school before aged 16, compared to 30 per cent of non-Roma.

3 The last official Census from Romania showed that the age group 0-24 made up 52 per cent of the total Roma population, compared to only 28 per cent of the overall population.

4 The official data from the National Institute of Statistics (insse.ro) show that in the third trimester of 2018, the labour market participation of young Roma people was 26 per cent, compared with the general participation of 66.2 per cent.

5 The precarious situation of Roma persons in Romanian society and on the Romanian labour market consists of an intertwinement of objective and subjective factors including documented exclusionary practices, and discourses, inclusionary policies, self-exclusionary perceptions, culturally embedded stereotypes, etc.

6 In the 1945-1953 period all agricultural land properties over 50 hectares were confiscated by the state and transformed into Agricultural Cooperatives Holdings (CAP), and into headquarters of the State Agricultural Holdings (IAS, GOSTAT, GAS) and of the Industrial Construction Enterprises (IACM), generically named the 'Collective'. Between 1957 and 1962 an accelerated and oppressive collectivization continued, with the result that, in 1962, 96 per cent of the arable land and 93.4 per cent of Romania's agricultural area were collectivized and owned entirely by the state. Outside Romania and Albania, no other Eastern European state has embraced such a full collectivization. Other communist countries, such as the DDR, Bulgaria, and Czechoslovakia, have collectively owned land, but peasants were allowed to cultivate individual batches separate from those of the Collective. In the 1990s the Collective's cooperatives were disbanded across Romania, and the agricultural land was given back to the former owners.

7 This abolished the restrained surface limitations and enshrined the principle of land restitution on the old site.

8 In 1990 Romania recorded 8.2 million employees, however in 2002 the total number of employees amounted to 4.6 million. Eurostat, eee.ec.europa.eu/Eurostat

9 The first National Roma Inclusion Strategy was released in 2001 and was followed by revised versions in 2006 and 2012, and the current one in 2015.

10 The main criticism was towards the lack of clear financing for the strategies, the implementation plans relying almost exclusively on financial resources from European funds. Another lacunar aspect identified was the lack of integration of the strategies in the already active Romanian social policies. Also, even though the strategies were addressed to the vulnerable category of Roma, the services and social benefits 
were distributed by a universalistic criterion without the provision of sets of social measures adapted to the specific needs of the Roma population.

11 The two case studies are extracted from the analysis on 'Factors of success in interventions addressed to labour market inclusion of Roma Persons' implemented within the E-qual project (for more details see www.e-qual-see.ro).

12 EU Roma pilot initiated by the European Parliament and supported by the Directorate General for Regional Policy, implemented by the Ruhama Foundation and partners, including the Bernard van Leer Foundation, Early Childhood Education and Care, the International Step by Step Association, the Roma Educational Fund, the Unity in Diversity Foundation, the United Nations Development Programme, the Slovak Governance Institute, and the Partners Hungary Foundation.

13 Low level of education, difficulties in handling legal and financial aspects of a business, the desirability of traditional skills, and occupations on the labour market.

14 The report is available at http://old.fonduri-ue.ro/posdru/images/downdocs/raport. lot.3.pdf

15 Identity documents and property or rental papers needed for the legal employment contract, but also for accessing health services, enrolling at school, and receiving social benefits and social services.

16 An important actor, but not the only one, being the National Employment Agency with its system at the county and local level.

17 EU Funds, World Bank, Roma Education Fund, Open Society Foundation and other entities financing Roma inclusion programmes.

\section{References}

Anan, K., Karacsony, S., Anton, S., Balica, M., Botonogu, F., Catana, A., Dan, A., Danchev, P., Farcasanu, D., Ferre, C., Florescu, R., Grigoras, V., Ionita, S., Ivasiuc, A., Kits, B., Kullman, A., de Laat, J., Magheru, M., Mathema, A., Mihalache, C., Moarcas, M., Ofiteru, L., Rokx, C., Rostas, I., Stanculescu, M., Swinkels, R., Tan, L., Thapa, D., and Weber, M. (2014). Achieving Roma inclusion in Romania: what does it take? Final report (Vol.2). [online] Washington, DC: World Bank Group, pp. 1-293. Available at: http://documents.worldbank.org/curated/en/149471468333037165/Final-report [Accessed 17 September 2018].

Anton, S., Balica, M., Botonogou, F., Catana, A., Dan, A., Danchev, P., Farcasanu, D., Ferre, C., Florescu, R., Grigoras, V., Ionita, S., Ivasiuc, A., Kits, B., Kullman, A., de Laat, J., Magheru, M., Mathema, A., Mihalache, C., Moarcas, M., Ofiteru, L., Rostas, I., Rokx, C., Stanculescu, M., Swinkels, R., Tan, L., Thapa, D., and Weber, M. (2014). Diagnostics and policy advice for supporting Roma inclusion in Romania. [online] Washington DC: World Bank Group, pp. 1-293. Available at: http://documents.worldbank.org/curated/en/599081468094457693/Diagnostics-and-policy-advice-forsupporting-Roma-inclusion-in-Romania [Accessed 17 September 2018].

Atkinson, M., Jones, M., and Lamont, E. (2007). Multi-agency working and its implications for practice: A review of the literature. Plymouth: CfBT Education Trust.

Baciu, E. (2017). Factors of Success in Interventions Addressed to Vulnerable Categories. In: T.M. Alexiu and E.L. Baciu (eds.), An Ethnography of the Social Access of Vulnerable Groups in a Developing Country: Romania. Craiova: Academica Greifswald, pp. 150-198. Bernat, A. and Rahman, S. (2014). Integration policies focused on Roma. Discussion paper on the policies applied in practice in selected EU Member States through comprehensive programmes. Budapest: TARKI Social Research Institute. 
Bodewig, C. and Kurekiva, L. (2009). Enhancing the Employment Chances of Roma. ECA KnowledgeBrief, March 2009, Vol. 2.

Boscoboinik, A. (2006). Ethnicization Process among the Roma Communities in Bulgaria. In: F. Ruegg, R. Poledna, and C. Rus (eds.), Interculturalism and Discrimination in Romania. Berlin: LIT Verlag, pp. 95-104.

Braham, M. (1993). The Untouchables: A Survey of the Roma People of Central and Eastern Europe. Geneva: UNHCR.

Breimo, J.P. and Baciu, E.L. (2016). Romanian Roma: An institutional ethnography of labour market exclusion. Social Inclusion 4(1), pp. 116-126.

Brewer, M. (1991). The social self: On being the same and different at the same time. Personality and Social Psychology Bulletin 17(5), pp. 475-482.

Cace, S., Preoteasa, A., and Stanescu, M. (eds.) (2011). Legal and Equal on the Labor Market for Roma Communities. Bucharest: Expert.

CASPIS - Comisia Nationala Anti-Saracie si Promovare a Incluziunii Sociale [National Committee Against Poverty and for Promoting Social Inclusion] (2003). Suport social pentru populatia de romi. Analiza problemeleor sociale: directii de actiune [Social Support for the Roma population. Analysis of Social Issues: Action Plan]. Bucharest: The Romanian Government.

CEDIME-SE - Center for Documentation and Information on Minorities in Europe Southeast Europe (2001). Minorities in Southeast Europe. Roma of Romania. [pdf] Bucharest: CEDIME-SE Center for Documentation and Information on Minorities in Europe - Southeast Europe, pp. 1-77. Available at: www.edrc.ro/resurse/rapoarte/ Roma_of_Romania.pdf [Accessed 4 December 2017].

Chirițoiu, A. (2013). Case study: Romano ButiQ. [pdf] Bucharest: Agenția Împreună. Available at: http://agentiaimpreuna.ro/wordpress/wp-content/uploads/2014/08/Casestudy-Romano-BoutiQ-Impreuna.pdf [Accessed 11 December 2017].

Cooper, M. and Lesser, J.G. (2002). Clinical Social Work Practice: An Integrated Approach. Needham Heights: Allyn \& Bacon.

de Laat, J. (2012). Reducing Vulnerability and Promoting the Self-Employment of Roma in Eastern Europe through Financial Inclusion. Washington DC: World Bank.

EAPN - European Anti-Poverty Network (2017). Inclusive labor markets. Building pathway approaches to quality employment. Position Paper, pp. 1-29. [pdf] Brussels: EAPN. Available at: www.eapn.eu/wp-content/uploads/2017/02/EAPN-2017-EAPNPosition-Inclusive-Labour-Markets-1006.pdf [Accessed 17 September 2018].

EC - European Commission (2018a). Civil society monitoring report on implementation of the national Roma integration strategy in Romania, pp. 1-65. [online] Brussels: European Commission. Available at: https://cps.ceu.edu/article/2018-04-17/ roma-civil-monitor-civil-society-monitoring-reports-available [Accessed 17 September 2018].

EC - European Commission (2018b). Communication from the Commission to the European Parliament and the Council. Report on the evaluation of the EU Framework for National Roma Integration Strategies up to 2020, pp. 1-12. [online] Brussels: European Commission. Available at: https://ec.europa.eu/info/sites/info/files/com_2018 785.pdf? fbclid=IwAR210kBBQ5w24rrjqDqgHOwOVsbjzCyjbdImSHa4TqUUE2CC $\bar{d}$ FNXWU6M6sg [Accessed 17 September 2018].

EC - European Commission (2018c). Country Report Romania 2018. Brussels: European Commission. Available at https://ec.europa.eu/info/sites/info/files/2018-europeansemester-country-report-romania-en.pdf [Accessed 15 December 2018]. 
EC - European Commission (2018d). Assessment of progress on structural reforms, prevention and correction of macroeconomic imbalances, and results of in-depth reviews under regulation, pp. 1-62. [pdf] Brussels: European Commission. Available at: https://ec.europa.eu/info/sites/info/files/2018-european-semester-country-reportromania-en.pdf [Accessed 17 September 2018].

Fenger, H. (2007). Welfare regimes in Central and Eastern Europe: Incorporating postcommunist countries in a welfare regime typology. Contemporary Issues and Ideas in Social Sciences, [online] 3(2), pp. 1-30. Available at: http://hdl.handle.net/1765/34876 [Accessed 11 December 2017].

Fine, M., Pancharatnam, K., and Thomson, C. (2000). Coordinated and integrated human service delivery models. SPRC Report 1(5), pp. 1-44.

FRA - European Union Agency for Fundamental Rights (2011). Fundamental rights: Challenges and achievement in 2011. Luxembourg: Publications Office of the European Union.

FRA - European Union Agency for Fundamental Rights (2016). Second European Union minorities and discrimination survey 2016, pp. 1-196. [online] Luxembourg: Publication Office of the European Union. Available at https://fra.europa.eu/en/project/2015/ eu-midis-ii-second-european-union-minorities-and-discrimination-survey [Accessed 17 September 2018].

Froy, F. and Pyne, L. (2011). Ensuring labour market success for ethnic minority and immigrant youth, OECF Local Economic and Employment Development (LEED) Working Papers, Vol. 9, pp. 1-88. [online] OECD Publishing. Available at: http://dx. doi.org/10.1787/5kg8g210547b-en [Accessed 11 December 2017].

Graddy, E. and Chen, B. (2006). Influences on the size and scope of networks for social service delivery. Journal of Public Administration Research and Theory, [online] Vol. 11, pp. 533-552. Oxford University Press. Available at: https://pdfs.semanticscholar.or g/9919/5d5e3e444216d533696f4c163290482aec9a.pdf [Accessed 4 December 2017].

Lazăr, T. (2016). Barriers in the Labour Market Inclusion Process of the Roma People. In: T.M. Alexiu (ed.), Access to Employment - A Practical Guide for the Specialists Working with Vulnerable groups. Craiova: Sitech, pp. 116-130.

Lazăr T. (2017). Factors that Influence the Labor Market Integration of Vulnerable Groups - A Bottom-up Perspective. In: T.M. Alexiu and E.L. Baciu (eds.), An Ethnography of the Social Access of Vulnerable Groups in a Developing Country: Romania. Craiova: Academica Greifswald, pp. 53-101.

Leichsenring, K. and Alaszewski, A.M. (eds.) (2004). Providing integrated health and social care for older persons - a European overview of Issues at Stake. Public Policy and Social Welfare, 28. Farnham: Ashgate.

Locke, R. (2001). Building trust - draft, pp. 1-34. [online] Massachusetts Institute of Technology. Available at: DOI 10.1.1.135.7316\&rep=rep1\&type=pdf [Accessed 4 December 2017].

McGinnis, T., Crawford, M., and Somers, S. (2014). A state policy framework for integrating health and social services. In: Issue Brief (Commons Fund) [online] Vol. 14, pp. 1-9. Available at: www.ncbi.nlm.nih.gov/pubmed/25065021 [Accessed 11 December 2017].

Messing, V. (2013). Active labor market policies with an impact potential on Roma employment in five countries of the EU. [online] NEUJOBS Working Paper no. 19.2, pp. 1-50. Available at: www.neujobs.eu/sites/default/files/D19_2_final.pdf [Accessed 17 September 2018]. 
Messing, V. (2014). Patterns of Roma employment in Europe. NEUJOBS [online] Working Paper no. 19.4, pp. 1-18. Available at: http://pdc.ceu.hu/archive/00007208/ [Accessed 17 September 2018].

Milotay, N. (2016). Integrated social services for more efficient service delivery. [online] European Parliamentary Research Service, pp. 1-5. Available at: www.europarl. europa.eu/RegData/etudes/BRIE/2016/583809/EPRS_BRI(2016)583809_EN.pdf [Accessed 17 September 2018].

Munday, B. (2007). Integrated social services in Europe. [online] Strasbourg: Council of Europe Publishing, pp. 1-93. Available at: www.coe.int $/ \mathrm{t} / \mathrm{dg} 3 /$ socialpolicies/socialrights/source/Publication_Integrated $\% 20$ social $\% 20$ services $\% 20$ in $\% 20$ Europe $\% 20$ E\%20(2).pdf [Accessed 17 September 2018].

Nasture, F. (2005). Comparing Romanian policies on employment: Lessons for the Roma decade. In: Overcoming Exclusion: The Roma Decade [online] pp. 1-7. Available at: http://pdc.ceu.hu/archive/00003486/ [Accessed 10 September 2018].

Nies, H. and Berman, P. (2004). Integrating Services for Older People: A Resource Book for Managers. Dublin: European Health Management Association.

Offe, C. (2010). Lessons learned and open questions. Transit [online] Vol. 8. Available at: www.eurozine.com/lessons-learned-and-open-questions [Accessed 17 September 2018].

Parsons, R., Hernandez, S., and Horgensen, J. (1988). Integrated Practice: A Framework for Problem Solving. National Association of Social Workers, pp. 417-421.

Preoteasa, A.M. (2008). Fenomenul ocuparii in Romania si dezvoltarea durabila [The employment phenomenon in Romania and sustainable development]. Calitatea Vietii XIX(1-2), pp. 53-69.

Rothstein, B. and Uslaner, E. (2005). All for all: Equality, corruption, and social trust. World Politics 58(1), pp. 41-72.

Scutaru, C. (2017). The Romanian national institutional social work system and social inclusion policies. Journal of Community Positive Practices XVII(3), pp. 25-33.

Shore, L., Randel, A., Chung, B., Dean, M., Holcombe Ehrhart, K., and Singh, G. (2011). Inclusion and diversity in work groups: Review and model for future research. Journal of Management 37(4), pp. 1262-1289.

Smith, D. (2005). Institutional Ethnography. A Sociology for People. Toronto: Altamira Press.

Stolle, D. (2002). Trusting strangers - The concept of generalized trust in perspective. Österreichische Zeitschrift für Politikwissenschaft 31(4), pp. 397-412.

Tache, I. and Neesham, C. (2011). The performance of welfare systems in postcommunist Europe. The cases of Romania and Bulgaria. International Journal of Economics and Research 2(5), pp. 90-107.

Turner, F.J. (1996). Social Work Treatment: Interlocking Theoretical Approaches, 4th Edition. New York: Free Press.

Warmington, P., Daniels, H., Edwards, A., Brown, S., Leadbetter, J., Martin, D., and Middleton, D. (2004). Interagency Collaboration: A Review of the Literature. Report of Stage 1 of the TLRPIII Learning In and For Interagency Working Project, Bath. Brighton: Teaching and Learning Research Council.

Weber, R. (1998). The Protection of National Minorities in Romania: A Matter of Political Will and Wisdom. In: J. Kranz and K. Kupper (eds.), Law and Practice of Central European Countries in the Field of National Minorities Protection after 1989, Warsaw: Center for International Relations. 
World Bank (2010). Roma inclusion: An economic opportunity for Bulgaria, Czech Republic, Romania and Serbia. Policy Note: Human Development Sector Unit Europe and Central Asia Region, pp. 1-37. [online] Washington: The World Bank. Available at: https://openknowledge.worldbank.org/handle/10986/12905 [Accessed 17 September 2018].

Zamfir, C. (2004). O analiza critica a tranzitiei. Ce va urma 'dupa'? [A critical analysis of the transition. What will come 'after'?]. Iasi: Polirom.

Zimmermann, K., Kahanec, M., Constant, A., DeVoretz, D., Gataullina, L., and Zaiceva, A. (2007). Study on the social and labour market integration of ethnic minorities. [online] IZA Research Report No. 16. Bonn: Institute for the Study of Labor, pp. 1-165. Available at: https://core.ac.uk/download/pdf/7141334.pdf [Accessed 17 September 2018]. 


\title{
Inclusion policies between EU framework and post-socialist heritage
}

\author{
Ingrid Fylling, Elena-Loreni Baciu, and \\ Janne Paulsen Breimo
}

\section{Introduction}

Deacon and colleagues (1997) state that:

The social policy of a country or a locality is no longer wholly shaped (if ever) by the politics of national government. It is increasingly shaped by the implicit and explicit social policies of numerous supranational agencies, such as ... the European Commission.

(Deacon et al., 1997, p. 10)

In this book, we have been concerned with how the European Union's (EU's) social inclusion policies are captured and shaped in post-socialist countries that have become members of the EU. Such an issue also recognizes that EU countries with a socialist past have shifted from one main supranational influence to another - from the Soviet Union to the EU. In Chapter 1, we expressed our view that there is reason to be critical of the rather naive assumption that challenges in the implementation of EU inclusion policy are only about national implementation problems. Rather it may be a complex combination of implementation problems, as well as problems with the policies themselves.

After ten years of documenting the post-socialist land and property reform in a small village from Romania, being a witness to the vanishing values of property for the newly reinstated owners, Katherine Verdery (2003) concludes that the departure from socialism, for the people concerned, was the 'twentieth century's second upheaval (the creation of Soviet-style socialism being the first)' (Verdery, 2003, p. xiv). And in chapter one, we asked the following two questions: Is it possible to identify common features across post-socialist EU countries regarding problems of implementing EU social inclusion policies? And if so - would it be reasonable or even possible to link those similarities to these countries' communist history and post-socialist experiences? The chapters in this book have in various ways illuminated the two questions formulated above, and we will use the main findings from each of the chapters to discuss how the questions may be answered. Post-socialist EU countries experience a wide number of 
challenges in implementing inclusion policies. We will discuss these experiences in terms of two interconnected but different topics: How policy itself defines and constructs specific understandings of target groups and of appropriate measures, and what kinds of implementation challenges are apparent in the different studies presented in the chapters.

\section{Similarities and differences in post-socialist welfare models}

As Kuitto (2016) points out, there is little to suggest that the post-socialist EU states have developed a common welfare model after the fall of communism. Nor have various post-socialist states adopted specific Western European welfare models. Rather, it is possible to find different hybrid models that combine elements from different classic welfare-state models, as presented by EspingAndersen (1989). Researchers also point out that post-socialist EU countries have acted and reacted fairly differently to the EU's plans and directives aimed at developing a European social policy. For instance, Lindstrom (2015) analyses conflicts arising from the dual processes of Europeanization and post-socialist transformations. Focusing in particular on Estonia and Slovenia, the author shows that elite actors within these two very different welfare capitalist states resisted, quite successfully, pressures from the EU to change their national models.

At the same time, research tends to reveal some patterns that transcend postsocialist states, and are in contrast to the 'classic' welfare states of Europe (Romano, 2014; Kuitto, 2016). Among those patterns are, according to Kuitto, (2016, pp. 173-174) a Bismarckian social insurance system (contributionfinanced social security), which Kuitto argues might point to a path-dependent institutional design, paths which may be drawn back to both World War II and to the state socialist period. Another common feature among Central and Eastern European (CEE) countries is that they spend a lot less money on welfare relative to GDP than most of the so-called Western European states do (ibid.). For the purpose of our discussions in this book, a third common feature is worth mentioning, namely that social services play only a very small role in the total state welfare funding of CEE countries (Kuitto, 2016, p. 174). This implies that people in need of social services are largely dependent either on market solutions or on family care.

The limitation of these findings, however, is that they are primarily based on policy analysis, and thus do not provide knowledge on what actually happens in local contexts where welfare services are produced. In this book, we have therefore been concerned with presenting studies that shed light on different levels: both policy level and welfare production at local levels.

Implementation challenges are of course not something that is specific to post-socialist countries. In fact, all democracies with central government shaping and adopting politics, which in turn are supposed to lead to changes in different 
decentralized levels of public administration and services, experience challenges with achieving successful policy implementation. However, the chapters in this book point to certain implementation problems that seems similar across studies and countries.

\section{Constructing inclusion policies in national contexts}

Social policy is a core in the Europe 2020 strategy, which aims to "ensure "inclusive growth" with high levels of employment and a reduction in the number of people living in poverty or at risk of social exclusion' (EU Parliament, 2017).

The European Union's role in shaping social policy is primarily addressed through two different strategies: Ensuring that EU policies are incorporated into national policies and initiating measures that can be implemented in different ways in different Member States (Cechin-Crista et al., 2013; EU Parliament, 2018). And even though the European Union's social policy is constantly being constructed and reconstructed by what is perceived to be the most central issue to be addressed at all times, the main principles of the European Union's social policy have been fairly firm for many years.

What is apparent from the beginning, and constituted the starting point for this book, is that post-socialist EU countries experience a wide number of challenges in developing and implementing effective inclusion policies for disadvantaged groups. As mentioned in the opening chapter, the departure from communism was rather abrupt for most of the currently EU member countries concerned. However, the strong popular support for the transition from communism to democracy in Central and Eastern Europe was not matched by the subsequent rulers' grand vision of the future, or a mature political, economic, or social planning process (Offe, 2010) that would have allowed transition to lead to evolution. The CEE countries relied on their Western counterparts to show them the way to prosperity, without much appreciation of the fact that different experiences lead to different conclusions and outputs.

Fundamental ideologies like democracy and the free market were 'borrowed' immediately from Western countries and have become the drivers and, at the same time, the measurement instruments for the post-socialist evolution. Societies that for a half of century had lacked any deployment of these two concepts, suddenly woke up the next day practising them. Free elections, unregulated consumption, the liberty to open up a business, the right to own property - were all new, shiny toys for citizens in these countries.

However, not all people's expectations materialized as such. Free and universal elections are, indeed, prerequisites of democracy, but do not always necessarily lead to it (Bowels and Gintis, 2011); as much as property rights are premises for development, they do not guarantee it.

Also, novelty in not always comforting over the long term. Fuelled, among other things, by resentment for failures that inevitably accompany exploration, 
the wave of enthusiasm generated by the collapse of communism has slowly dissipated. Moreover, the disintegration of the official institutions of the former system in post-socialist countries proved not to be accompanied by the complete dissolution of the informal networks or practices that supported it. Placed in a completely new context, with rapid change threatening to sweep away everything that was familiar to them, people slowly started to lean back on 'old habits' or try to restore them. Taming fundamental change was the price paid by some of the CEE countries to reduce entropy ('Let's change, but not too much! Keep what can be kept'). This involved, among other things, keeping in key leading positions people that had been there during the communist regime (Hogea, 2010), or, as Verdery (2003) notes, the self-renewal of the old power structures.

In several chapters of this book, the authors have pointed out that policy itself defines and constructs target groups and appropriate measures within the context of the national state. How 'disability' or 'Roma background' are defined and understood, has a major impact on what is seen as relevant measures. Taking Hungary as an example, Andras Pap argues in his chapter that Hungary defining Roma as a national minority creates several dilemmas: it fails to comprehend the complexity of Roma issues, it is collectively based and thereby neglects the individual justice-based, anti-discrimination oriented approach, and it may be seen as a colonialist/patriarchal endeavour - lacking genuine grass roots initiatives.

One important and interesting consequence of such a way of understanding Roma issues is that many of the challenges that the Roma population experience, in fact are shared with many within the majority population. But within a framework of defining Roma as a national minority, the policies are not able to address the real problems satisfactorily. Joanna Kostka illustrates some of the same in her chapter based on Slovakia, when she points out that the cohesion policy framework in Slovakia has framed Roma exclusion in terms of individual or group adaptability, with very little attention given to general institutional and structural discrimination by which Roma are confronted. This tendency has permeated both EU social policy and Slovakia's national policies, and has generated ineffective measures, which consumed a lot of resources, without providing satisfactory results and structural reforms.

In analysing the impact of EU social inclusion on the development of the social policies in post-socialist Poland, Ryszard Szarfenberg points out the complex interdependences between the internal and the external factors that shaped Polish social policy over three decades. He notes how the necessity to integrate EU policy into the national policy, coupled with the motivation for enhancing EU funds absorption, and the need to provide an answer to the shifting social and economic needs of the population produced, in time, an institutional mix, 'plagued' with problems of coordination and collaboration between central, regional, and local level bodies, and also between different sectors (public, private for profit, private nonprofit). As such, he concludes that the creation of the Polish social inclusion policy was the result of rather timely 
economic, political, and administrative decisions taken at critical junctures during the period of systemic transition.

Every area of politics has built-in specific understandings of the subject that the politics applies to. Two categories have been particularly in focus in the chapters when it comes to inclusion policies and inclusion practices, namely people with Roma backgrounds and people with disabilities. Inclusion policies express a particular understanding of what it means to belong to a category that is defined outside the societal norms. Such understandings will in turn affect how political measures are designed and implemented. Teodor Mladenov and Gabor Petri's study focuses on the efforts for the deinstitutionalization processes of persons with disabilities in Hungary and Bulgaria. They see this step forward towards the assimilation of the social model of disability and the independent living philosophy not as an internal drive of the two countries, but as a reaction to the EU requirements and motivated by the EU funding. They argue that the current disability policy in CEE countries is deeply rooted in the representations of disability under state socialism, which was reshaped, rather than replaced, by the neoliberal transformations that followed the fall of the communist regime. Fitting new ideology over old structures meant in practice remodelling and refurbishing old residential institutions, or even building new ones, with EU funds. What should have been a natural ideological transition from the medical approach on disability towards the social model, as witnessed in other (Western) countries, in CEE countries (due to the rush towards being received into the European family, among other things) was perceived as a legal/technocratic (formal) requirement. Hence, Bulgaria and Hungary have reproduced a 40-yearold British concept of disability policies, without considering the dangers of income support pointed out by UPIAS in 1978. By distinguishing between 'affirmative' and 'transformative' redistributive measures, the authors argue that family income support measures have affirmative effects, while more community based services such as supported living and personal assistance might have a more transformative effect. They call for a more updated understanding of disability that is in line with contemporary EU disability policy, which focuses on service-oriented support for disabled people.

Something very similar is also pointed out in Johans Tveit Sandvin and Teodor Mircea Alexiu's chapter, which discusses the gap between the Romanian national disability policies, which are increasingly in compliance with the social model (and the EU model), and the current status of their implementation, still heavily relying on the medical approach. They find a potential explanation for this gap in the concept of cultural lag, a phenomena which occurs when the evolution of non-material culture (like established practices) does not keep pace with the evolution of material culture (often expressed through new technology or changes imposed from outside). However, they also point out some insightful alternative explanations, which consider a variety of historical and political circumstances that go far beyond the disability inclusion policies and seem to show a convergence towards the notion of pre-maturity of the country's accession to 
the EU. This brings up an interesting observation made by Offe (2010) about the duration the influence of EU policy has over the national policies of the member countries, after the accession of a new Member State has been granted: as he puts it, 'when accession itself is a done deal [...] conditionality has lost most of its pre-2007 leverage' (ibid., p. 10). Switching the focus from the 'stick' of the pre-accession conditionality to the 'carrot' of the access to EU funding, we discover, in the chapter of Urszula Bronisz and co-authors, a two-part explanation for the rapid growth of the social economy sector in post-socialist Poland: (1) the intensity and extent of the social problems (formulated by them as needs); and (2) the accessibility of EU funding for entities from this sector (formulated as opportunities). This is a fortunate circumstance of need meeting opportunity in post-socialist development and implementation of social inclusion policy.

Another example is provided by Joanna Kostka, who argues that the cohesion policy framework in Slovakia has framed Roma exclusion in terms of individual or group adaptability with little attention given to general institutional and structural discrimination. Rather than addressing the poverty problems, the policy's ethnicization of this issue has led to channelling of funding towards measures that aimed to change the behaviour of target groups, namely Roma communities. Similar arguments are made by Tijana Morača and Paul Stubbs.

\section{Implementation challenges: between supranational policy and local practice}

While the last section was about analysing how policies are constructed in certain ways, this section focuses on the relations between central inclusion policies and local practice. One case of disconnection between policy and its implementation is brought up by Alexandra Strážnická's analysis of the accessibility of political activities for people with disabilities in Slovakia. She points out that, although the national legislation clearly abides by the principles of the UN Convention on the Rights of Persons with Disabilities on granting them access of rights to political participation (with the notable exception of the persons whose mental capacity is affected), the possibility of exercising these rights is hindered by the lack or insufficiency of those provisions that should make them applicable (no regulations to ensure accessibility by the political parties, no legal norms imposed on holders of public office to hold meetings in venues which are accessible, etc.). Thus, another contrast between form and substance is observed. A nod on this matter is also given in Theofild-Andrei Lazăr and Melinda Dincă's chapter, which mentions the reluctance of the Romanian governments to fulfil clear financial responsibilities towards the implementation of the Romanian National Roma Inclusion Strategies, relying in turn on the use of European funds to implement them. However, they go on with showing that, even in the absence of central authorities' clear engagement with tackling the social inclusion barriers faced by Roma persons, and relying exclusively on EU funding, important progress can be achieved. They argue that the integrated approach in tackling 
social inclusion barriers for vulnerable persons relies on grassroots initiatives and, thus, puts more emphasis on the local actors and their important role in changing the status quo and obtaining the desired outcomes, on their own.

The clearly important role of local actors in implementing social policy, when they are driven by solid convictions and the desire to improve the situation of disadvantaged groups, is also brought up in the chapter of Gábor Szüdi and Jaroslava Szüdi. In assessing the successful implementation of a national-wide inclusive education programme that took place in Slovakia, they stress the importance of the involvement and motivation of local actors as fundamental preconditions. Their existence allowed for mutual learning processes and empowerment of the target groups to take place, which in turn, contributed to even greater engagement of the members of the community in the programme. All these small steps towards increasing the involvement of the local actors in driving the change processes, are in fact underpinning the durability of the change itself.

On a different note, when assessing the role of the local stakeholders in promoting or shaping social policy, other premises have to be taken into consideration also. Morača and Stubbs dedicate a lot of analytical attention to the ways and mechanisms through which local actors, unpack, interpret, and put into practice the 'policy advice coming from the centre'. Based on the ethnographic analysis of key aspects of a Roma children inclusion project implemented in Serbia, they expose the active role of the 'local' in altering or downright contesting the main principles of the very policy they were involved in implementing. The translation of the 'central' to 'local', when it comes to national context, is mirrored in the last part of their chapter, by a similar axis of policy translation, but this time reproduced at EU versus national level, in the 'semi-peripheral' (Blagojević, 2009 apud Morača and Stubbs) context of south-eastern Europe, which has to transcend the 'backwardness' of socialism and move towards the modern liberal democracy that characterizes the EU.

Szüdi and Szüdi notice the difficulties faced by the local actors involved in the educational programme studied, in moving beyond the local level on a broader scale. They conclude that such initiatives are, after all, only complementary to systematic governmental education programmes and innovative in their scope. As such, it is the responsibility of the governments to pay attention to what happens on the ground and incorporate at policy and national programme levels, social innovations that prove effective. In the conclusion of their chapter, Lazăr and Dincă formulate a list of practical recommendations on how the national level system for social support services could be redesigned/restructured so as to put into action the principles of the integrated approach, in order to provide the best type of support to persons that deal with complex social issues (for example Roma persons in Romania).

Some of the chapters also thematize the challenges in traditional understandings of implementation as designing policies that are then relatively unproblematically adapted and implemented at the local level. Morača and Stubbs aim at providing new insights into the 'black box' of policy implementation 
by focusing on how policies are met at the local level. Rather than show passive acceptance, actors contest and alter dramatically aspects of the policy. The authors argue that constructing social disadvantage primarily in ethnic terms might have counter effects on the ground: members of the majority population feel that their own impoverishment is left unacknowledged. Their analysis opens up a more nuanced perspective on implementation, taking into account the local context in which the political measures are supposed to work.

Another feature highlighted in some of the chapters is weak civil societies, especially in the scope of voluntary organizations that could presumably influence how policy is designed and implemented. For example, Sandvin and Alexiu point out that the low number of disability organizations can at least partially explain why people with disabilities are held in a medical understanding of what it means to have a disability. Howard (2003) states that low organizational participation is a feature found in most post-socialist countries. He points out that civil organizations can represent an important driving force in the development of relatively new democracies, while low-level civilian involvement is understandable given the political situation that existed under the communist regime. When citizens of post-socialist countries refrain from organizing their interests in non-governmental organizations, bureaucratic organizations are not faced by any opposition.

\section{Understanding implementation of inclusion policy in post-socialist countries: the significance of local forces}

Although with great respect for many researchers who warn against exaggerating common traits and overlook major differences when comparing welfare models in different countries (Kennet, 2001; Romano, 2014; Kuitto, 2016), we have in this book looked for different experiences with, and expressions of, common implementation challenges in terms of inclusion policy in post-socialist EU countries. We argue that there are similar challenges across post-socialist EU states, shaped by common political and social features. The features are partly about the policy itself, and partly about challenges in the actual implementation processes.

When EU inclusion policy is dealt with at the national political level, it will be transformed in the context of the individual country's cultural and historical reality (Kennett, 2001). Daniell (2014, p. 2) expresses this as follows: 'The weight of evidence from the literature, clearly supports the hypothesis that national culture has a significant influence on public policy'. The policy analyses in the chapters of this book show that both 'disability' and 'Roma' are defined and constructed in accordance with how one understands the phenomenon in each country, which in turn has a strong impact on measures. When disability is understood as a revenue protection problem alone, other aspects of the phenomenon are overlooked in policy formulation. The understanding of what it means 
to have a disability seems to be marked by the legacy of a paternalistic and medically defined definition that characterized the period of socialism. Then the lack of political change is not only about implementation challenges, but about the fact that EU policy itself interacts with national ideas that transform the policy.

There are also challenges with the actual implementation of policy. A good many of these challenges may seem to be related to the fact that social services only play a very small role in the total state welfare funding of the Central and Eastern European countries (Romano, 2014; Kuitto, 2016), while the civil society organization is weak (Howard, 2003). Implementing EU inclusion policy requires a local service apparatus that many post-socialist countries have not yet established.

By encouraging an analytical focus on local welfare production in postsocialist EU countries, this book contributes to widening our knowledge on how implementation challenges are experienced at local level in these states. However, much more research is needed, in order to fully grasp how processes of Europeanization and post-socialist transformations are linked to local welfare production.

\section{References}

Bowels, S. and Gintis, H. (2011). Democracy and Capitalism. Property, Community and the Contradictions of Modern Social Thought. Routledge Revivals. New York: Routledge.

Cechin-Crista, P., Mihut, A., Dobrin, G., and Blaj, S. (2013). The Social Policy of the European Union. International Journal of Business and Social Science 4(10) [Special Issue - August 2013].

Daniell, K. (2014). The Role of National Culture in Shaping Public Policy: A Review of the Literature. HC Coombs Policy Forum Discussion Paper. Canberra: Australian National University Press.

Deacon, B., Hulse, M., and Stubbs, B. (1997). Global Social Policy: International Organizations and the Future of Welfare. London: Sage.

Esping-Andersen, G. (1989). The Three Political Economies of the Welfare State. Canadian Review of Sociology/Revue canadienne de sociologie, February, 26(1), pp. 10-36.

EU Parliament (2017). www.europarl.europa.eu/RegData/etudes/PERI/2017/600416/ IPOL_PERI(2017)600416_EN.pdf.

EU Parliament (2018). www.europarl.europa.eu/EPRS/TD_Persons_with_disability.pdf.

Hogea, A. (2010). Coming to Terms with the Communist Past in Romania: An Analysis of the Political and Media Discourse Concerning the Tismăneanu Report. Studies of Transition States and Societies 2(2), 16-30.

Howard, M.M. (2003). The Weakness of Civil Society in Post-Communist Europe. Cambridge: Cambridge University Press.

Kennett, P. (2001). Comparative Social Policy. Buckingham: Open University Press.

Kuitto, K. (2016). Post-communist Welfare States in European Context. Patterns of Welfare Policies in Eastern Europe. Cheltenham: Edward Elgar Publishing.

Lindstrom, N. (2015). The Politics of Europeanization and Post-Socialist Transformations. London: Palgrave Macmillan UK. 
Offe, C. (2010). Lessons learned and open questions. Eurozine, January 28, 2010 www. eurozine.com/lessons-learned-and-open-questions.

Romano, S. (2014). The Political and Social Construction of Poverty. Central and Eastern European Countries in Transition. Bristol: Policy Press.

Verdery, K. (2003). The Vanishing Hectare: Property and Value in Postsocialist Transylvania. New York: Cornell University Press. 


\section{Index}

Note: The page locators in bold and italics represents tables and figures, respectively

absolute poverty, concept of 38

active social policy, concept of $117-18$, 120,132

adult education 206

adults with mental disorders 19

Amsterdam Treaty (1995) 109, 175

anti-psychiatry movement 16

apprentice schools 176

'Assistants for Independent Living' scheme 25

asylum-seeking, in the EU 44

Atlas of Roma Communities, The 64 at-risk-of-poverty threshold 55

austerity, policy of 61 ; anti-austerity campaigns 26; impact on social inclusion practices 36 ; neoliberal retrenchment and 20,25,28; protest against 28; public sector retrenchment and 49 ; in social security 5,48 ; spending on public services 45

Autistak Orszagos Szovetsege (AOSZ) see Hungarian Autistic Society

Balcerowicz, Leszek 160

Bašić, Goran 39

'benchmarking' of progress 37

Brewer's Optimal Distinctiveness Theory 196

Bulgaria: anti-austerity campaigns 26 ; 'Assistants for Independent Living' scheme 25; Centre for Independent Living-Sofia (CIL-Sofia) 25, 26; civil society organizations 25 ; disabilityrelated campaigns in 25; Personal Assistance Bill 26; Social Assistance Act (1998) 17, 22
Central and Eastern European (CEE) countries 3, 16, 100, 111, 217, 224; democracies of 88 ; disability policy in 18-20; EU membership 55; neoliberal dismantling of welfare states 27; policy formation in post-socialist 17; right of disabled people 16; Visegrad (V4) countries 179; welfare policies and systems in 5

centralized education system 177

Centre for Independent Living-Sofia (CILSofia) 25,26

Charter of Fundamental Rights of EU 55

child allowance 43-4, 47, 66, 130

childhood education 184, 192, 206

Churchill, A. 171

citizenship, rights of 49,59,61, 64, 80

Citizens' Initiatives Fund 161

civic society organizations 145

civil patrols 63

civil society $1,35,109,112,143-4,153$; civil society organizations $12,17,144$, 224

co-configuration, meaning of 203

Common Basic Principles on Roma Inclusion 62

communism, collapse of 219

communities at risk, of social exclusion 63

communities of practice 203

community-based care 16-17, 21

community-based services $22,25,42$

Community Initiative EQUAL 2000-2008 161

community services $17,20,23,28-9$

compulsory education, requirements for 176-7 
Convention on the Rights of Persons with Disabilities (CRPD 2006) 9, 16, 221; Article 19 of 16, 18; Article 29 of 141; European Commission's Report on the Implementation of 21; Hungary's ratification of 22; Slovakia's ratification of 141

Council of Europe: on cultural rights and situations of new minorities 83; Framework Convention for the Protection of National Minorities 78; Parliamentary Assembly of 78; Poland's accession to 124

Country Specific Recommendations (CSRs) 100, 118

critical juncture, concept of 119, 123, 127, 131-2, 220

cross-ethnic networks, diversity of 207 cultural lag, concept of 106-8, 112, 220 culture of poverty $65,92 \mathrm{n} 1$

Czechoslovakia: communist rule in 142; dissolution of 142; inter-war economic growth 143; market deregulation in 143; return to Europe 143; Velvet Revolution (1989) 142-3

Decade of Roma Inclusion Initiative 37, $39,86,91$

decentralized democracy, notion of 120 deinstitutionalization (DI): in Bulgaria 22; challenges of 17; of disability policy in CEE countries 18-20, 29; discourses, agencies, and practices of 16; of domestic policy formation 21-3; EU accession and attendant integration on 18; European Disability Strategy 2010-2020 and 21; human rights discourse 22; in Hungary 17, 22; local mobilizations $23-8$; reform of 16-17; and residential institutions for disabled people 16; role of EU in 20-1

Deinstitutionalization Strategy for 2011-2041 (Hungary) 17, 22

democratic capitalism 6, 134 disability: civic society organizations in 145; definition of 102, 113n3; discrimination based on 103; functional defect level of 145; as functional disorder 145 ; medical assessments of 145 ; notions of 145; severe disability 145; in Slovak legal system 145; social model of 16, 27; social perceptions of 106, 108
Disability Alliance 27-8

"disability as tragedy" model 105

disability movement, political significance of $4,108-9,112$

disability pension, people living on 19, 124

disability policy-making 16 ; "disability as tragedy" model of 105; in Europe see

European Disability Strategy (2010-2020); in postsocialist countries 108; in Romania 99-100, 105; social housing criteria 102-3

disabled people, right of: in Bulgaria 25; demands for better services 24; Disability Strategy 2010-2020 20; disabled people's movement 16; domestic mobilizations in support of 17-18; EU's legislation on 20; fight for dignity and respect 109; income substitution and 27; to independent living and community inclusion 16 ; living outside institutions 20; policy in CEE countries 18-20; service-oriented services and 220; in Soviet Union 24; under state socialism 18 ; for vocational rehabilitation 109

disciplinary neoliberalism 37

discrimination, prohibition against 146 double discourse, politics of 66,91 'double movement' of policy translation 41

East-European social model 12n1 economic integration 143 economic planning, theory of 121 economic well-being 171 education system: apprentice schools 176; based on communist ideology 177; centralized 177; childhood education 206; core-skills resilient 181; curriculumbuilding 184-5; and economic competitiveness 183; EU education policy 176; European school systems 176; free school choice 184; governance and management of 183 ; 'hybrid' education system 183, 187; market economy aspects of 183; 'money follows students' principle 184; normative system of funding 177; in OECD countries 179, 181; Programme for International Student Assessment (PISA) 179; quality of opportunity in 177; school integration of Roma people 177; school segregation, 
education system continued level of 183; in Slovakia 175-85; socioeconomic environment 183; Teach for Slovakia (TFS) programme 185-8; vocational schools 176

employment: barriers to 200; in European Union 55; gender gap in 195; Roma work inclusion see Roma work inclusion, framework for; in Serbia 45; in social cooperatives 168 equality, rights of $61,79-80$ equal treatment, principle of $66,80,93 \mathrm{n} 10$, 146

ethnic classification system 39

ethnic minorities $75,77,78,82-3,86-8$, $91,126,198$; rights of 80

ethnic prejudices 47

ethno-business 81

ethno-corruption 81-2

ethno-racial communities 92

EU Member States 37; social inclusion performance by 3,175

EU NUTS (Nomenclature of Territorial Units for Statistics) II level 159

Eurocentrism 111

Europe 2020 Strategy 2-3, 37, 70, 144, 179, 218; EU-level target indicators on education 176; Europe 2020 Agenda and the European Disability Strategy 2010-2020 144; European Semester under 121; social policy 218

European Charter for Regional or Minority Languages 88

European cohesion policy 58

European colonization, cultural consequences of 111

European Commission 119, 199; Action Programme to Combat Social Exclusion 2002-2006 126; fight against poverty and exclusion 175; joint report on social inclusion 175 ; social protection intervention 175; working groups 126

European Convention on Human Rights 78

European Council in Lisbon 143

European Court of Auditors 59-60

European Court of Human Rights (ECHR) 19,77

European Disability Strategy (2010-2020): EU social inclusion agenda and 144; formulation of 20-1; implementation of 107; objectives of 10; in Romania 103-4; universal applicability of 107
European Employment Strategy (EES) 2, 125,127

European Expert Group (EEG) 16

European Framework for Social and Territorial Cohesion, A 61

European ideology 2

Europeanization, of social policy 6

European Ombudsman 21, 69

European Parliament 69, 89, 147; antidiscrimination policies 78 ; resolution on the protection of minorities 78

European school systems 176

European Semester Country Report 99; Specific Recommendations for Poland 136 n24

European Social Fund (ESF) 11, 56, 159; for creation of inclusion projects for Roma population 56; Excessive Deficit Procedure (2009-2015) 118; Learning Network on Roma Inclusion 69; for Polish social policy 118

European Social Innovation Competition 202

European Structural and Investment Funds (ESIFs) 21

European Union (EU) 1; Agency for Fundamental Rights (FRA) 55, 184; asylum-seeking in 44; Charter of Fundamental Rights of 55; communityled local development strategies (CLLDs) 69; Council Recommendation on Key Competences for Lifelong Learning (2018) 176; Council Recommendation on promoting Common Values, Inclusive Education, and the European Dimension of Teaching (2018) 176; Disability Strategy 2010-2020 20; education policy 176 ; employment rate 55 ; equalization and anti-discrimination policies 4; Framework Directive 101; Framework for National Roma Integration Strategies 37, 69, 91; Observatory on Policies to Combat Social Exclusion 175; Phare programme 90; Poland's accession to 116, 161, 165; Progress Reports on Economic and Social Cohesion 40, 60; role in shaping social policy 218; Romania's accession to 99,109 ; Serbia's accession to 43

European values and principles 111 Eurostat 176 
EU social inclusion policies 2, 3-4; antiRoma discourses 38; comprehensive paternalist care 6; developments in 144; Europeanization of 6; evolution of 133; failure in pre-accession Poland 121-4; in former communist countries 10 ; impact of 219; implementation in postsocialist countries 4-5, 118, 216; joint report on social inclusion 175; legacy of previous successes $128-32$; in postsocialist countries 216; post-socialist welfare model 6; problems of implementing 5, 216-17; on supported living 22; unintended consequences of 35; 'usages of Europe' approach in 125

Evans, John 23

Excessive Deficit Procedure (2009-2015) 118

\section{Fico, Robert 66}

financial crisis of 2008 3, 20

Framework Convention for the Protection of National Minorities (1995) 78, 88

Fraser, Nancy 8, 18, 28, 79

free market 122, 218; demand-supply dynamics of 198; of private economy 120

'Fundamental Principles of Disability' document 26-7

Good Start Project 201

Grad, Banjski 46-7

Grethen, Henri 59

guaranteed minimum income 122-3, 124

gypsy 12 n2; ethnic identity as 77

\section{Hall, Stuart 40}

household poverty, risk of 100, 141, 144

human capital 56, 61; Human Capital Operational Programme 159, 161, 167

human rights: discourse on 22; in Hungary 29 n2; international treaties on 147 ; in Slovakia 141

human rights organizations 199

Hungarian Autistic Society 24

Hungary: Academy of Sciences 80; antiausterity campaigns 26; in context of European policy 89-91; Equal Opportunities of Disabled People Act 29n3; during First World War 87-8; historical path dependence 87-8; minority-rights legislative framework
80-3, 84-5; national-ethnic-racial minorities 75; National Roma SelfGovernment 76-80; National Social Inclusion Strategy (2011) 86; National Social Inclusion Strategy II (2014) 86; post-communist condition 87-8; race, ethnicity, and nationality 76-80; Rights of Nationalities Act (2011) 82, 86; Roma as a national minority in 75 , 86-7; Roma community in 83-4; Roma policies 80; Social Act (1993) 22; social inclusion policies 75 ; victims of discrimination 75

'hybrid' education system 183, 187

Inclusion of Roma Children (IROC) project $36,42-8$; beneficiaries of 44,46 ; on children facing difficulties and exclusion in education system 43 ; knowledge hierarchies and resistance 48; local hierarchies and practices 45; scope of 43; support for Roma pupils at risk of leaving school early 45

inclusion policies: construction of 218-21; between EU framework and postsocialist heritage 216-24; EU social inclusion policies see EU social inclusion policies; implementation challenges for 221-3; in national contexts 218-21; in post-socialist countries 223-4; post-socialist welfare models 217-18; Roma work inclusion see Roma work inclusion, framework for; between supranational policy and local practice $221-3$

independent living movement 9, 23-4; in Bulgaria 25

institutional ethnography 42, 200 institutional inequalities 61, 69 integrated care, in health services 197 inter-institutional partnerships 209 International Convention on the Elimination of All Forms of Racial Discrimination (1965) 76

invalidity pensions, public expenditures on 19,27

jobs, creation of 59

Kaliňák, Róbert 66 Kingfisher, Catherine 41 knowledge hierarchies and resistance 48 
'Konstantín' strategy 179

Kymlicka, Will 79

labour force adaptation 59

labour market 163, 202; evaluation of 195; in Poland 116, 122, 126; in Romania 101, 108, 196; Roma's vulnerability on 199

land property, right to $198,210 \mathrm{n} 6$

Learning Makes Sense 185

'Learning Slovakia' strategy 185

Lenoir, René 36

Lewis, Oscar 92n1

lifelong education workshops 206

Lipsky, Michael 5

Lisbon Strategy (2000-2010) 3, 4, 121, $126,133,158$

Local Data Bank of Statistics Poland 167

Manolova, Maya 26

marginalized communities 61, 69; integration of 56; Marginalized Roma

Communities (MRCs) see Marginalized

Roma Communities (MRCs)

Marginalized Roma Communities

(MRCs): in Hungary 75; in Slovakia 65

market economy $60,85,122,165,183$, $185,187,191,198$

material culture, evolution of 107, 220

Mečiar, Vladimír 143

membership-based organization 163

mental disorders, adults with 19

mental health service users, movement of

16

minority rights 79; collective (national) 86; European minority rights treaties and conventions 88; in Hungary 88; ombudsman 81

minority self-governments (MSGs) 80, 82; function and design of 80-1, 84; institution of 81

mobilizations, to seek social change: local 23-4; past 24-5; present 25-8

moral underclass discourse 36

Mosse, David 40

multi-agency activity: dimensions of 203; integration 203; joint investment 203; meaning of 203; organization 203

National Association of the Disabled (Norway) 108

National Catalog of Social Cooperatives 167 national disability support system 25

nationalities: concept of 79-80, 82; Rights of Nationalities Act (2011), Hungary 82, 86

nationality self-government 82

national minority $78,82,88$; defined 79

National Ukrainian Self-government 82

'need-opportunity-output' research model 165,166

neoliberal austerity 25,28

neoliberal capitalism 91

network creation, consequences of 203

non-governmental organizations (NGOs)

$25,35,122,159,161-3,167,199,204$

non-membership organization 163

non-profit organizations 158,163

Observatory on Policies to Combat Social Exclusion 175

October Revolution (1917) 18

Ogburn, William F. 107

Open Method of Co-Ordination (OMC) 2, 37, 118, 126; Social Inclusion Process (social OMC) 127

Open Society Foundation 37

Permanent Court of International Justice 77

personal assistance schemes, demands for 25

person-in-situation, concept of 196, 204 persons with disabilities: accessibility of elections communication and broadcasting 150-1; access to and accessibility of voting and elections 148-50; 'bottom-up' approach for implementing rights of 153-4; civicsociety approach for social inclusion of 144; civil and political rights of 146-52; denial of rights to 147 ; deprivation or restriction of legal capacity $147-8$; exercise of civil and political rights by 152-4; living in residential care 152; National Programme on Development of Living Conditions for Persons with Disabilities in all Living Areas (2001) 144; political rights of 154; promotion of rights of 154; in Slovakia 145; Slovak Library for the Blind 151; social exclusion of 146; state-based approach for social inclusion of 144; targeted policies 144; 'top-down' approach for 
implementing rights of 153-4; vocational activation of 122 ; voting procedures, accessibility of 151-2; voting rights regulation for 146-7, 154

Pew Research Center 8

Phare programme 90

Poland, social policy in 500 Plus (government's flagship programme) 130; accession to the European Union (EU) 116, 161, 165; activation and integration programme 129; active inclusion policy 117; Act on Employment and Counteracting Unemployment of 1995 121; Act on Employment and Unemployment of 1991 121; Act on Employment of 1989 121; Act on Promotion of Employment and Institutions of the Labour Market (2004) 125; Act on Social Assistance (2004) 125, 129; adoption of EU law 124; Community Initiative EQUAL 2000-2008 161; consequences of social policy development 123-4; cooperatives, foundations, and associations registered in REGON 163; disability policy 116; EU funds for 118; Europeanization of 118; European Semester Country Specific Recommendations for Poland 136n24; ex-ante conditionality and the successor of NSIS 130-1; Excessive Deficit Procedure (2009-2015) 118; failure of EU social inclusion policy 121-4; First European Social Economy Conference (2002) 160; focus on at-risk groups 122; guaranteed minimum income policy 122-3; income test and minimum income standard 125; institutional interpretation of 123-4, 131-2; labour market 116, 122, 126; literature review of 117-19; membership of Council of Europe 124; National Development Strategy 2007-2015 161; National Programme for Social Economy Development (KPRES) 130, 161; National Programme for Social Protection and Social Inclusion 2006-2008 161; National Programme for the Adoption of the Acquis (1998) 123; National Strategy of Social Integration 120, 126-7; number of social cooperatives per 10,000 population 166; Open Method of Coordination (OMC) document 118; in post-transformation decade 117; Programme for Counteracting Poverty and Social Exclusion 120; ratification of the ESC 123; sheltered employment 116; social economy and $159,160-5$; social exclusion policy $116,120,124$; social inclusion policy $116,119,122$, 129; State Fund for Rehabilitation of Disabled Persons 164; success of EU social inclusion policy implementation in accession period (2001-2006) 124-5; theoretical and methodological perspective of 119-21; unemployment and poverty issues 121 ; vocational rehabilitation services 116 political security 143 post-socialism, idea of 7-8, 17, 42, 143 post-socialist welfare models, similarities and differences in 217-18

poverty: absolute poverty 38 ; culture of 92n1; eradication of 175; EU commitment to combating 126 ; household poverty $100,141,144$; in Poland 121; poverty alleviation, strategy of 26, 38; 'poverty reduction' paradigm 38; relative poverty 38; in Romania 100; Roma population living in 199; World Bank-led Poverty Reduction Strategy 38

primary school pupils, dropout prevention for 206

private enterprises: not-for-profit 158 ; social aims of 158

problem-solving, community capacity for 186, 203

ProCare project 197

Programme for International Student Assessment (PISA) 179; results of 15-year-old Slovak students 181; results on social inclusion and equity in education 181

public administration and services 127 , 161, 218; decentralization of 123,160 , 218

public education 80

public-private partnerships 204

public sector employees $45,47-8$

public services 45; retrenchment of 19

public transport network 205

Puscas, Vasile 109 
race and ethnicity: in Hungary 76-80; notion of 77; social justice and equality 79-80; vague categories of 76-9 racial discrimination 76-7 racial minorities $75,78,80$ racism, practices of $10,48,61,64,66,90$, 106

Ratzka, Adolf 23

Reding, Viviane 37, 60 redistribution-recognition dilemma $92 \mathrm{n} 5$ relative poverty, concept of $38,192 \mathrm{n} 1$ religious affiliation, of minorities 83 residential caregivers 152

residential segregation, through loss of jobs and discrimination 184, 199 revenue protection, problem of 223 rights of people with disabilities, in the EU 10

Roma Education Fund 201

Roma ethnic minorities: criminality of 66 ; cultural and linguistic characteristics 83; Decade of Roma Inclusion Initiative 86; as distinct political group 85 ; educational and cultural programmes 86; employment rate of 199; engaged in "paid work" 199; ethnicity of 9 ; from ethnic to national minorities 86-7; ethno-cultural identity of 89; folklore classes 81 ; historical oppression of 61; Hungarian policies on $80,83-7$; inclusion schemes 60 ; income sources of 198-200; integration of marginalized 63; international Romani movement 84; legislative framework regarding 88 ; living in severe poverty 199; as marginalized communities 61-2, 70n3; National Roma Self-Government 86; nationbuilding project 91 ; natural sociohierarchical rules of social life in 65 ; parliamentary representation of 89 ; Phare programme 90; political concept of 83-4; 'problematic' settlements 66; racist violence 56; religious affiliation 83; right to property 198; in Romania 99; school integration of 177; selfgovernments 85; Slovak Government Plenipotentiary for 63; in Slovakia 62, 177; social conditions of 85 ; social exclusion of 59-60; socioeconomic conditions of 56, 59; stigmatization of 67; violence against 198
Roma exclusion 199; concept of 59-62, 67; definition of 64, 69; ethnicization of 61; EU 'frames' on 62; framing of 65; idea of culture as a cause of 60 ; multidimensional aspects of 69; patterns of 65 ; problematization of 61 ; 'systemic' causes of 65

Roma identity, protection of 85

Roma inclusion project: Common Basic Principles on Roma Inclusion 62; Decade of Roma Inclusion 37, 39; double-tier system 67-8; dynamics of 35; ESF Learning Network on Roma Inclusion 69; ethnic classification system 39; EU Progress Reports on 40; financing of 56; focus on Roma people right 44-5; funded by European Union (EU) 35, 36-40, 60; impact of austerity measures 36; Inclusion of Roma Children (IROC) project 36, 42-8; 'instrumentalized' concerns regarding 45; NGO-implemented project 42 ; notion of Roma vulnerability and 38; reformulation of 35; in Romania 200; social inclusion policy framework 38 , 199; Strategy for the Improvement of the Status of Roma 39; Strategy of Social Inclusion of Roma (2016-2025) 39; theory and method for study of 40-2; Uncertain Impact: Have the Roma in Slovakia Benefited from ESF? 63

Romania: accession to the European Union 99, 109; Anti-discrimination Law (2000) 102; cultural lag in implementation of disability policy $106-8$; disability equality gaps in 100; employment discrimination of Roma 199; Habsburg Empire 110; healthcare system of 105 ; historical legacy of disability policy in 108-9; implementation of EU disability policy in 99-100, 103-4; Inclusion of Romanian Citizens Belonging to the Roma Minority 200; inclusive disability policy in 105; income sources of Roma community in 198-200; labour market in 101, 108, 196; labour-market integration of Roma 99; in late Middle Ages 110; medicalized approach towards disability 104-6; National Action Plan 104; National Authority of Disabled Persons 105; National Council for Combating Discrimination (NCCD) 
102; National Strategies for Roma 206; opposition against EU disability policies in 109-11; under Ottoman rule 110; Ownership Act (2005) 198; perception of disability in 108; post-communist welfare state in 200; Protection and Promotion of the Rights of Persons with a Handicap 101; risk of household poverty in 100; Roma work inclusion, framework for 195-210; situation for disabled people in 100-3; Society without Barriers for People with Disabilities 2016-2020; A (2016) 104; state welfare arrangements in 108

Romano ButiQ (RBQ) initiative 202-3, 205

Roma poverty 61 ; ethnicization of 57 ; framing of 66

Roma representation, concept of 63, 70, 90

Roma rights, violation of 56, 64

Roma work inclusion, framework for: concept of 196; coordinated interventions, implementation of 203-4; effectiveness of 195-6; elements for improving 203; employment discrimination and 199; European political discourse and 197; Good Start Project 201; implementation of 198; income sources 198-200; individualized interventions based on needs assessments 204-5; integrated approach to $196,197-8$; interorganizational field of 203; interventions based on trust and close relations 207-8; main barriers in 195; multi-level interventions 205-7; multilevel systems intervention of 197; in paid work 195; in Romania 195-210; social contexts of 197; social systems theory of 197; use of integrated approach for improving 200-8; vulnerability on the labour market 199 ; vulnerable state of 195

Ruhama Foundation 202; Intervention at the Colony from Telechiu 201, 203-4, 206-7; on living conditions of Roma people 201

Schengen visa regime, liberalization of 44 school dropout, risk of 44, 126 school management, decentralization of 183

school segregation, level of 183 selling the bride, practice of 44

Serbia: accession to EU 43; asylumseeking in the EU 44; community-based social services in 47 ; employment opportunities in 45; EU accession negotiations 43 ; opportunity to travel without visas 44; policy reform discourse in 47; Roma project see Roma inclusion project; social work in 47

service-oriented services, for disabled people 220

sheltered employment 116

Shore, Lynn 196

Slovak Blind and Partially Sighted Union 151

Slovakia 2004-2006 National Action Plan of Social Inclusion 144; Act No. 365/2004 on Equal Treatment in Certain Areas and Protection against Discrimination 177; Act on Civil Proceedings 148; Act on Election to Local Self-government Bodies 147; Act on Upbringing and Education (2008) 177; allocation of ESF funding 63; ANED Report 2013 149; Code of Judicial Review of Administrative Decisions (CJRAD) 148; Comprehensive Country Monitoring Report (2003) 62; Constitutional Court of 142, 147; Constitution of 146; coreskills-resilient pupils in 185; Country Report (2011) 66; educational indicators of 180; educational inequality measures in 182; educational performance of 179 ; EU membership of 62; European funding for the integration of Roma citizens 62; Field Social Work and Community Centres programmes 67; Government Plenipotentiary for Roma Communities 63; 'Konstantín' strategy 179; 'Learning Slovakia' strategy 185 ; levels of schooling in 176; Local Strategies of Comprehensive Approach 70; Marginalized Roma Communities (MRCs) 65; Monitoring Committee (MC) 68; National Council of 148, 150; National Strategic Reference Framework for the 2007-2013 funding 64; Pedagogical and Specialized Employees Act (2009) 177; people with visual impairment in 151; period of compulsory schooling in 176; persons 
Slovakia continued

with disabilities in see persons with disabilities; PISA results of 15-year-old students 181; primary and secondary school system 175-85; Roma minority, situation of 62; Rules of Civil Contentious Litigation (RCCL) 148; Rules of Civil Non-contentious Litigation (RCNCL) 148; school founders and types of schools in 178; Social Development Fund 63; special status of persons with disabilities in 142-5; State Educational Programmes 177; Strategy for Roma Integration (2014-2020) 177; Strategy of the Slovak Republic for the Integration of Roma up to 2020 (2011) 64; 'Take-Away Package' programme 63; Teach for Slovakia (TFS) programme 185-8; Uncertain Impact: Have the Roma in Slovakia Benefited from ESF? 63

Slovak Library for the Blind 151 social assistance system 116; allowance 46; services 122

social bonds 60 social capital 144, 158, 159, 161, 165 social cohesion, Durkheim's theory of 36 , $117,144,159,161,190$

social contracts, ideologies of 3, 125, 129 social cooperatives $120,125,127-33,129$, $161,163-4,166-8$

social democracy and neoliberalism 154 social dialogue 79

social division of work 117

social economy: among EU countries 158; availability of EU funds for 160; Community Initiative EQUAL 2000-2008 161; concept of 158-9, 162; decline of 160; definition of 162 ; entities operating in the sphere of 162; factors influencing the development of 165; Law on Associations 160; legal and economic status of 160 ; methods framework 165-71; 'need-opportunity-output' research model 165; Polish model of 159, 160-5; potential of 160 ; professional activation of people 164; resurgence of 158; revival of 159; self-sustained 202; structure and development of 162-5 social economy entities 158, 161, 170; activity of 169; Act on Social Enterprise and Supporting 130; categories of 162,
166; creation of 167-8; development of 160 ; involvement in overcoming social exclusion 166; labour market integration processes 171; legal and economic status of 160; municipal selfgovernment 160; in Poland 162-5, 171; social entrepreneurship 159; social integration 160; structure and development of $162-5$

social economy sector $161,164-5$; activity of 160; development of 169; growth of 158, 221; in Poland 165-8, 170-1, 221; revival of 159; system to strengthen 159 social employment 124-9, 131, 164 social employment institution 127, 131, 172n1

social enterprises $131,158-9,162-4,171$; development of 163; integration work of 125

social entrepreneurship 171, 202; idea of 159

social exclusion 2, 144; communities at risk of 63; Community Action Programme to Combat Social Exclusion 2002-2006 126; concept of 36, 176; defined 4; EU commitment to combating 126; factors leading to 165; of Roma community see Roma exclusion social inclusion 56, 79; barriers for vulnerable persons 222; concept of 3; of disadvantaged populations 2; EU policies on see EU social inclusion policies; measurement of 3 ; need for active policies to promote 37 ; performance by EU Member States 3; of persons with disabilities 144; strategies of fostering 4; of vulnerable groups 42,222

social inequalities $59,61-2$ social innovation 186-8, 191-2, 202, 222;

European political discourse as 197 social insecurity 58,91

Social Insurance Agency 145

social insurance system 217

social integration and activation 118 social integration clubs 163-4

social interactions, process of 187

socialism: end of 142; Soviet-style 216; state socialism see state socialism social isolation 141

social justice: group justice model 79; individual justice model 79; notion of 6 , 79-80 
social marginality, concept of 121,128 , 162

social "misfits" 36

social pathology, concept of 121

social policies, Europeanization of 200, 218

social problems, individualization of 61 , 70, 120-1, 124, 134, 166, 171, 196, 221

social protection 43,175 ; national regulations and policies dealing with 144 social rehabilitation 129, 132, 164 social representation 79

social security system: retrenchment of 19 ;

in Russia 19; in Slovakia 183

social services system 198; community-

based 22-3, 47; delivery system for 200 ,

208; of residential type 23

social solidarity 61

societal groups, idea of 77

solidarity economy see social economy

Soviet-style socialism, creation of 216

Stabilization and Association Agreement (2008) 38

standard of living 19

state economy, decentralization of 198

state enterprises, privatization of 19

state-run residential institutions, collapse of 19

state socialism 6, 29n1, 61, 105, 108;

application of 7; collapse of 112 ;

constructions of disability under 18 , 220; doctrine of 7, 18

state socialist economies, management of 18

Structural Funds (SFs) 56, 63, 65;

allocation of 64; approach to policy implementation 57-9; dimensions of 57; discursive elements of 57; effectiveness of 57 ; formulation of 56 ; general workings of 57; implementation of 56, 66-8; instrumentality of 57; legitimacy of 57,66 ; operational programme (OP) 63; pre-assessment of 57

structure-agency paradigm 7

subsidiarity, principle of 153

supported living 28-9, 220; definitions of 22; demands for 25

Teach for All network 185

Teach for Slovakia (TFS) programme 12; access to a high-quality education for children 188; aim of 187; assessment of
185-8; capacity-building process 191 ; functioning of 187; higher quality education system 187; implementation of 187,189 ; interview sample 188 ; Likert-scale questions 187; main findings 188-92; operation of 187; outof-school programmes 190; as part of global Teach for All network 185; private and public decision-making 192; social innovation 186, 192; teaching time for minimum teacher certification 192

Treaty on the Functioning of the EU (TFEU) 103

unemployment, issue of 121,199

Union of the Physically Impaired Against Segregation (UPIAS) 27-8, 220

United Nations (UN): Convention on the Rights of Persons with Disabilities (CRPD 2006) 9, 16, 21, 100, 103, 141, 221; United Nations Development Programme (UNDP) 37, 63

Vacaroiu, Nicolae 110

Velvet Revolution (1989) 142-3

Verdery, Katherine 216, 219

victims of discrimination 75

Visegrad (V4) countries 179

vocational activation $122,134 \mathrm{n} 1,162$

vocational rehabilitation services 116,121 vocational schools 176

vote, right to $81,142,146-7,152,154-5$

vulnerable groups, social inclusion of 5 , 42-3, 127, 196, 201, 204, 206

wealth, redistribution of 61

welfare production, in post-socialist EU countries 217, 224

welfare states, in European former communist countries: dynamics of 6-7; Europeanization of social policy 6; path departure (policy diffusion) 6; path dependency 6; welfare capitalist states 217

workfare, concept of 117

working within networks 203, 208; definition of 203

work-integration mediation services 206

World Bank 37, 130; Poverty Reduction

Strategy 38; Roma Education Fund 201

Wygnański, K. 162-3 


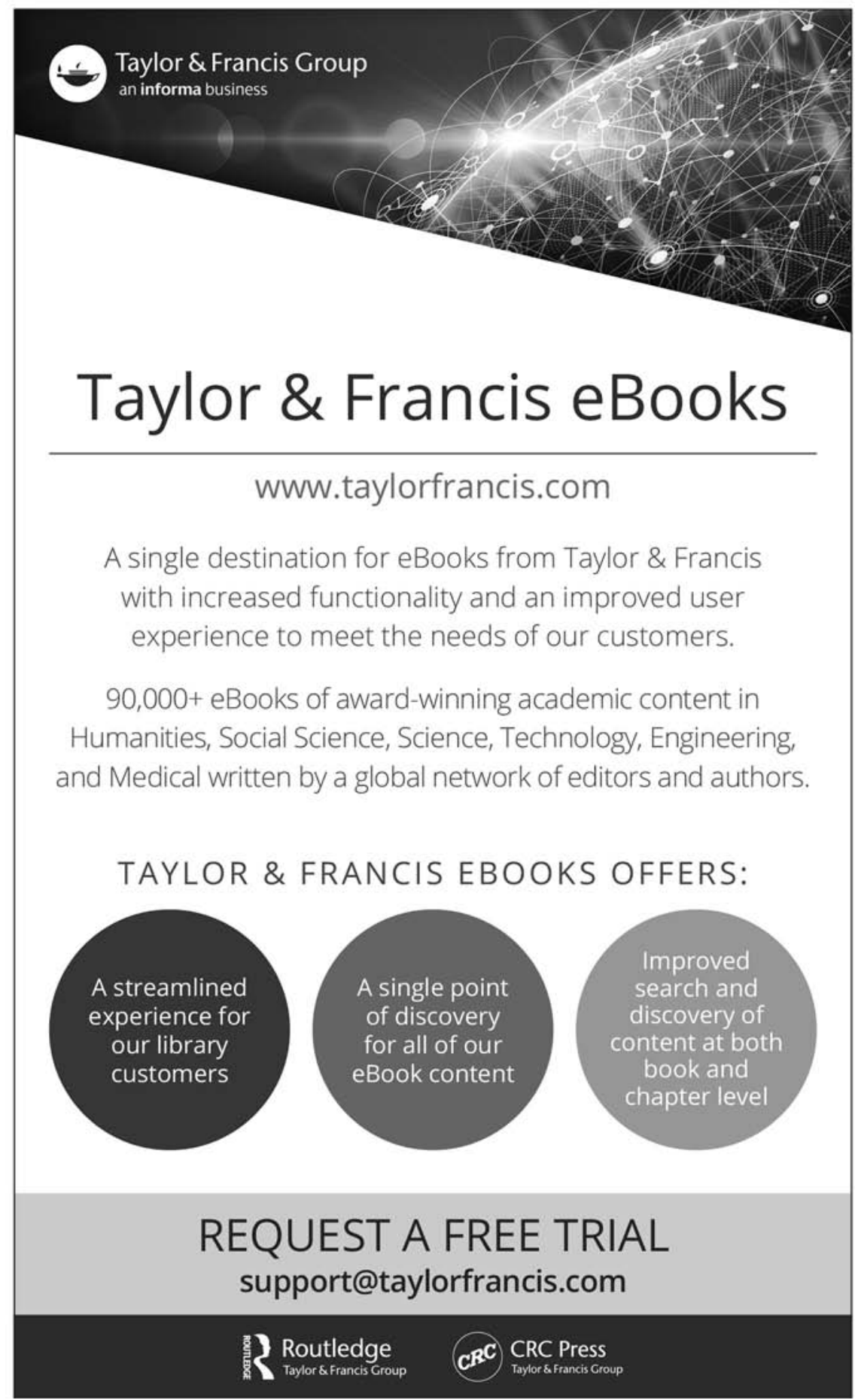

